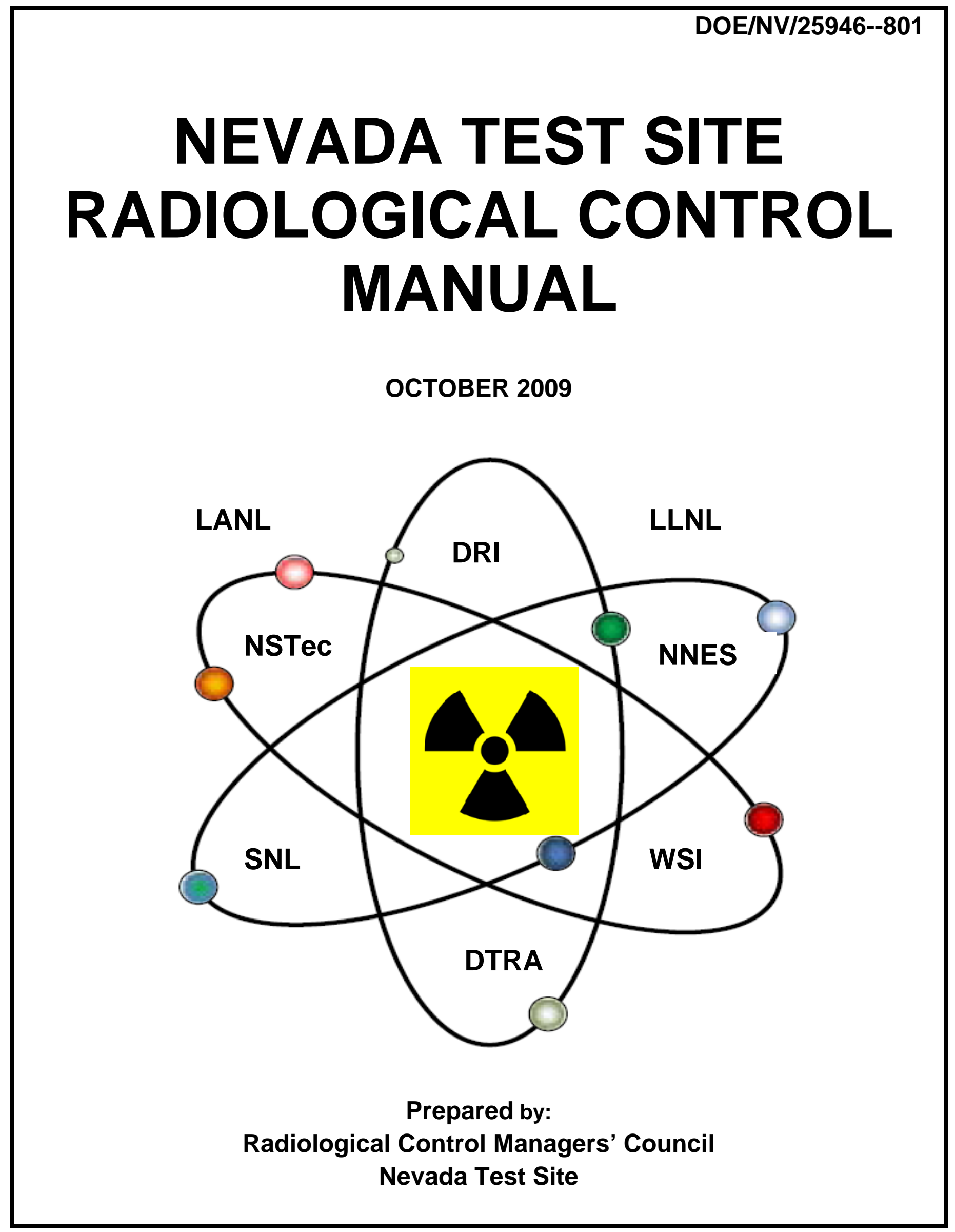




\section{Disclaimer}

This report was prepared as an account of work sponsored by an agency of the U.S. Government. Neither the U.S. Government nor any agency thereof, nor any of their employees, nor any of their contractors, subcontractors or their employees, makes any warranty or representation, express or implied, or assumes any legal liability or responsibility for the accuracy, completeness, or usefulness of any information, apparatus, product, or process disclosed, or represents that its use would not infringe privately own rights. Reference herein to any specific commercial product, process, or service by trade name, trademark, manufacturer, or otherwise, does not necessarily constitute or imply its endorsement, recommendation, or favoring by the U.S. Government or any agency thereof. The views and opinions of authors expressed herein do not necessarily state or reflect those of the U.S. Government or any agency thereof.

Available for sale to the public, in paper, from:

U.S. Department of Commerce

National Technical Information Service

5285 Port Royal Road

Springfield, VA 22161-0002

Telephone: 800.553 .6847

Fax: 703.605.6900

E-mail: orders@ntis.fedworld.gov

Online ordering: http://www.ntis.gov/help/ordermethods.aspx

Available electronically at: http://www.osti.gov/bridge

Available for a processing fee to the U.S. Department of Energy and its contractors, in paper, from:

U.S. Department of Energy

Office of Scientific and Technical Information

P.O. Box 62

Oak Ridge, TN 37831-0062

Telephone: 865.576 .8401

Fax: 865.576.5728

E-mail: reports@adonis.osti.gov 


\section{NEVADA TEST SITE RADIOLOGICAL CONTROL MANUAL}

OCTOBER 2009

Coordinated and Compiled by:

National Security Technologies, LLC

P.O. Box 98521

Las Vegas, NV 89193-8521 
THIS PAGE INTENTIONALLY LEFT BLANK 


\section{REVISION LOG}

\begin{tabular}{||l|l|c|c||}
\hline \hline $\begin{array}{l}\text { Document Number } \\
\text { DOE/NV 10630-59 }\end{array}$ & \multicolumn{1}{|c||}{$\begin{array}{c}\text { Document Title } \\
\text { NV/YMP Radiological Control Manual }\end{array}$} & $\frac{\text { Revision }}{\frac{\text { Number }}{0}}$ & $\begin{array}{c}\text { Date } \\
12 / 01 / 1992\end{array}$ \\
\hline $\begin{array}{l}\text { Training Required: N/A } \\
\text { Brief Description of Revision: Initial Issue }\end{array}$ \\
\hline
\end{tabular}

\begin{tabular}{|c|c|c|c|}
\hline$\frac{\text { Document Number }}{\text { DOE/NV 10630-59 }}$ & $\frac{\text { Document Title }}{\text { NV/YMP Radiological Control Manual }}$ & $\frac{\frac{\text { Revision }}{\text { Number }}}{1}$ & $\frac{\text { Date }}{12 / 28 / 1994}$ \\
\hline
\end{tabular}

This document supersedes DOE/NV 10630-59, "NV/YMP Radiological Control Manual," Revision 0 dated December 1, 1992.

Brief Description of Revision: A complete revision to reflect the recent changes in mission and organizational structure at the Nevada Test Site (NTS) and Yucca Mountain Project (YMP); to anticipate imminent changes in contracts and contractual obligations; to be in agreement with Revision 1 of the U.S. Department of Energy (DOE) Radiological Control Manual (April 1994); for use as proof of compliance with Title 10 Code of Federal Regulations (CFR) Part 835, "Occupational Radiation Protection"; and for use as a reference document for Contractor/User ("Tenant Organization") Radiological Protection Programs.

\begin{tabular}{||l|c|c|c||}
\hline \hline $\begin{array}{c}\text { Document Number } \\
\text { DOE/NV/11718--079 }\end{array}$ & $\begin{array}{c}\text { Document Title } \\
\text { NV/YMP Radiological Control Manual }\end{array}$ & $\frac{\text { Revision }}{\text { Number }}$ & $\begin{array}{c}\text { Date } \\
11 / 13 / 1996\end{array}$ \\
\hline $\begin{array}{l}\text { This document supersedes DOE/NV 10630-59, "NV/YMP Radiological Control Manual," Revision } \\
1 \text { dated December 28, 1994. } \\
\text { Brief Description of Revision: A complete revision to reflect the recent changes in mission and } \\
\text { organizational structure at the NTS and YMP; for use as proof of compliance with 10 CFR 835 } \\
\text { and DOE N 441.1, "Radiological Protection for DOE Activities"; and for use as a reference } \\
\text { document for Tenant Organization Radiological Protection Programs. }\end{array}$ \\
\hline
\end{tabular}

\begin{tabular}{|c|c|c|c|}
\hline $\begin{array}{l}\text { Document Number } \\
\text { DOE/NV/11718--079 }\end{array}$ & $\frac{\text { Document Title }}{\text { NV/YMP Radiological Control Manual }}$ & $\frac{\frac{\text { Revision }}{\text { Number }}}{3}$ & $\frac{\text { Date }}{5 / 20 / 1999}$ \\
\hline \multicolumn{4}{|c|}{$\begin{array}{l}\text { This document supersedes DOE/NV/11718--079, "NV/YMP Radiological Control Manual," } \\
\text { Revision } 2 \text { dated November 13, } 1996 . \\
\text { Brief Description of Revision: A complete revision to reflect the recent changes in compliance } \\
\text { requirements with } 10 \text { CFR 835; and for use as a reference document for Tenant Organization } \\
\text { Radiological Protection Programs. }\end{array}$} \\
\hline
\end{tabular}




\section{REVISION LOG (continued)}

\begin{tabular}{||l|c|c|c||}
\hline $\begin{array}{c}\text { Document Number } \\
\text { DOE/NV/11718--079 }\end{array}$ & $\begin{array}{c}\text { Document Title } \\
\text { NV/YMP Radiological Control Manual }\end{array}$ & $\frac{\text { Revision }}{\text { Number }}$ & $\begin{array}{c}\text { Date } \\
\text { May 2000 }\end{array}$ \\
\hline This document supersedes DOE/NV/11718--079, "NV/YMP Radiological Control Manual," \\
Revision 3 dated may 20, 1999. \\
Brief Description of Revision: A revision to reflect changes during the DOE/NV review cycle for \\
compliance requirements with 10 CFR 835; and for use as a reference document for Tenant \\
Organization Radiological Protection Programs. \\
\hline
\end{tabular}

\begin{tabular}{||l|c|c|c||}
\hline $\begin{array}{l}\text { Document Number } \\
\text { DOE/NV/11718--079 }\end{array}$ & \multicolumn{1}{c|}{$\begin{array}{c}\text { Document Title } \\
\text { NV/YMP Radiological Control Manual }\end{array}$} & $\frac{\text { Revision }}{\text { Number }}$ & $\begin{array}{c}\text { Date } \\
\text { November } \\
2004\end{array}$ \\
\hline $\begin{array}{l}\text { This document supersedes DOE/NV/11718--079, "NV/YMP Radiological Control Manual," } \\
\text { Revision 4 issued in May 2000. } \\
\text { Brief Description of Revision: A complete revision to reflect the recent changes in mission and } \\
\text { organizational structure at the NTS and YMORD; and for use as a reference document for } \\
\text { Tenant Organization Radiological Protection Programs. }\end{array}$ \\
\hline
\end{tabular}

\begin{tabular}{||c|c|c|c||}
\hline $\begin{array}{c}\text { Document Number } \\
\text { DOE/NV/25946--801 }\end{array}$ & $\begin{array}{c}\text { Document Title } \\
\text { Nevada Test Site Radiological Control } \\
\text { Manual }\end{array}$ & $\begin{array}{c}\frac{\text { Revision }}{\text { Number }} \\
0\end{array}$ & $\begin{array}{c}\text { Date } \\
\text { October } \\
2009\end{array}$ \\
\hline $\begin{array}{l}\text { This document supersedes DOE/NV/11718--079, "NV/YMP Radiological Control Manual," } \\
\text { Revision } 5 \text { issued in November 2004. } \\
\text { Brief Description of Revision: A complete revision to reflect the recent changes in compliance } \\
\text { requirements with 10 CFR 835; and for use as a reference document for Tenant Organization } \\
\text { Radiological Protection Programs. }\end{array}$ \\
\hline
\end{tabular}




\section{DISTRIBUTION}

U.S. Department of Energy

National Nuclear Security Administration

Nevada Site Office

Technical Library

P.O. Box 98518, M/S 505

Las Vegas, NV 89193-8518

U.S. Department of Energy

National Nuclear Security Administration

Nevada Site Office

Public Reading Facility

c/o Nuclear Testing Archive

P.O. Box 98521, M/S 400

Las Vegas, NV 89193-8521

U.S. Department of Energy

Office of Scientific and Technical Information

P.O. Box 62

Oak Ridge, TN 37831-0062
$1 \mathrm{CD}$ (uncontrolled)

$1 \mathrm{CD}$ (uncontrolled)

1 electronic copy (uncontrolled)

The organization responsible for establishing additional distributions for this document is the National Security Technologies, LLC, Radiological Control Department.

Distribution information shall be forwarded, in writing, to:

National Security Technologies, LLC

Radiological Control

P.O. Box 677, M/S NTS271

Mercury, NV 89023-0677 
THIS PAGE INTENTIONALLY LEFT BLANK 
TENANT ORGANIZATION MANAGEMENT CONCURRENCE

\section{ACRONYMS}

\section{OVERVIEW}

\section{CHAPTER 1 COMMITMENT AND RESPONSIBILITY FOR RADIOLOGICAL CONTROL}

PART 1 NTS Radiological Control Manual

PART 2 Leadership in Radiological Control

PART 3 Improving Radiological Performance

PART 4 Tenant Organization Radiological Control Organization

PART 5 NNSA/NSO Management

Appendix 1A Radiological Control Managers' Council Charter

Appendix 1B Generic Assessment Plan for the Tenant Organizations' Nevada Test Site Radiation Protection Program 10 CFR 835.102 Internal Audits

Appendix 1C Site-Wide ALARA Committee Charter

\section{CHAPTER 2 RADIOLOGICAL STANDARDS}

PART 1 Administrative Control Levels and Dose Limits

PART 2 Contamination Control and Control Levels

PART 3 Posting

Appendix 2A Guidelines for Control of Emergency Exposures

Appendix 2B Weighting Factors for Organs and Tissues

Appendix 2C Non-uniform Exposure of the Skin

\section{CHAPTER 3 CONDUCT OF RADIOLOGICAL WORK}

PART 1 Planning Radiological Work

PART 2 Work Preparation

PART 3 Entry and Exit Requirements

PART 4 Radiological Work Controls

PART 5 Reserved

PART 6 Special Applications

PART 7 Reserved

PART 8 Design and Control

Appendix 3A Physical Access Controls for High and Very High Radiation Areas

Appendix 3B Contamination Control Practices

Appendix 3C Guidelines for Personnel Contamination Monitoring with Hand-Held

Survey Instruments 


\section{CHAPTER 4 RADIOACTIVE MATERIALS}

PART 1 Radioactive Material Identification, Storage, and Control

PART 2 Releasing and Transporting Radioactive Material

PART 3 Radioactive Source and Radiation-Generating Device Controls

PART 4 Reserved

PART 5 Reserved

PART 6 Support Activities

\section{CHAPTER 5 RADIOLOGICAL HEALTH SUPPORT OPERATIONS}

PART 1 External Dosimetry

PART 2 Internal Dosimetry

PART 3 Respiratory Protection Program

PART 4 Handling Radiologically Contaminated Personnel

PART 5 Radiological Monitoring and Surveys

PART 6 Instrumentation and Calibration

\section{CHAPTER 6 TRAINING AND QUALIFICATION}

PART 1 Radiological Training and Qualification

PART 2 General Employee Radiological Training

PART 3 Radiological Worker Training

PART 4 Radiological Control Technician Qualification

PART 5 Other Radiological Training

PART 6 Reserved

\section{CHAPTER 7 RADIOLOGICAL RECORDS}

PART 1 Requirements

PART 2 Employee Records

PART 3 Reserved

PART 4 Radiological Control Procedures

PART 5 Radiological Monitoring and Surveys

PART 6 Instrumentation and Calibration Records

PART 7 Reserved

PART 8 Radiological Reporting 


\section{TABLES}

Table 2-1 Summary of Occupational Dose Limits

Table 2-2 Surface Contamination Values in $\mathrm{dpm} / 100 \mathrm{~cm}^{2}$

Table 2-3 Criteria for Posting Radiation Areas

Table 2-4 Criteria for Posting Contamination, High Contamination, and Airborne Radioactivity Areas

Table 2A-1 Guidelines for Control of Emergency Exposures

Table 2B-1 Tissue Weighting Factors for Various Organs and Tissues

Table 2C-1 Non-uniform Exposure of the Skin

Table 3B-1 Guidelines for Selecting Protective Clothing

Table 4-1 Labeling Requirements for Radioactive Materials

Table 4-2 Allowable Total Residual Surface Contamination Values in $\mathrm{dpm} / 100 \mathrm{~cm}^{2}$

Table 6-1 Radiological Training Requirements

\section{FIGURES}

Figure O-1 NTS Location

Figure O-2 NTS Area Designations, Principal Facilities, and Testing Areas

\section{GLOSSARY}

\section{INDEX}

REFERENCE APPENDIX: 10 CFR 835 (January 1, 2008) 
THIS PAGE INTENTIONALLY LEFT BLANK 
Nevada Test Site Radiological Control Manual

October 2009

TENANT ORGANIZATION MANAGEMENT CONCURRENCE

SENIOR SITE EXECUTIVES:

Mo2Butchte 10/22/09

Dr. Stephen M. Younger Date National Security Technologies, LLC

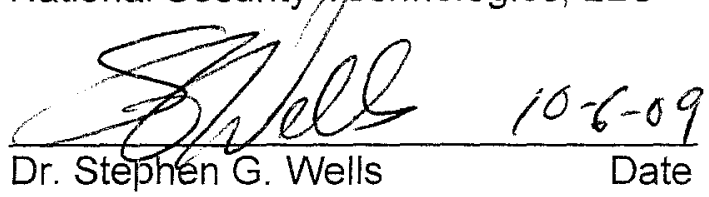

Desert Research Institute

$\frac{\text { Mack D: MRorysop } 10 / 20 / \% 9}{\text { Mate }}$ Defense Threat Reduction Agency
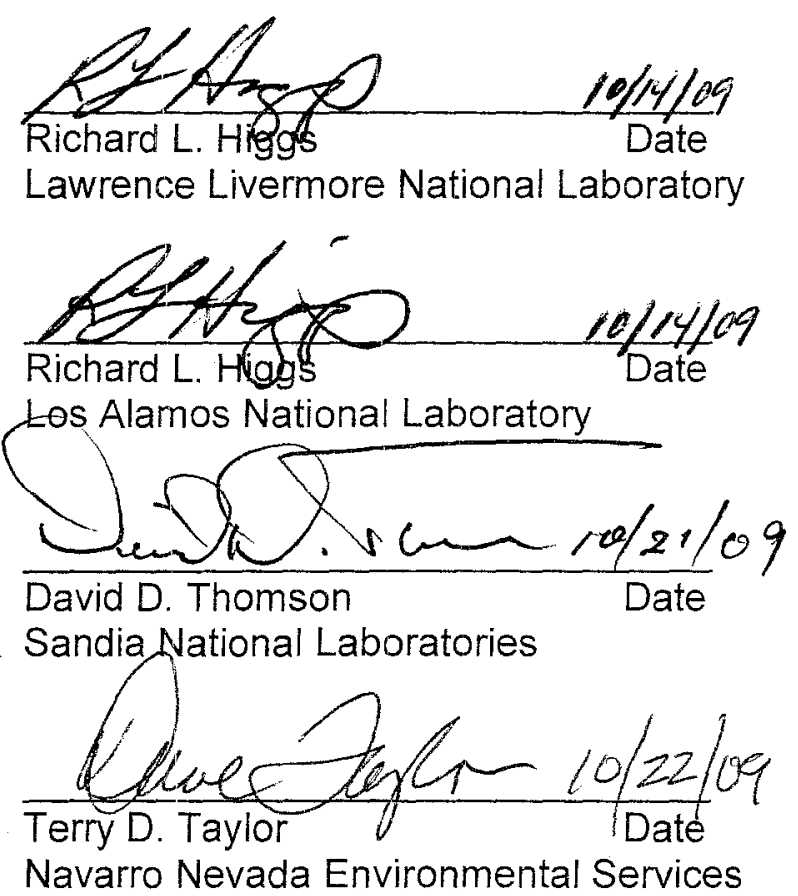

RADIOLOGICAL CONTROL MANAGERS:
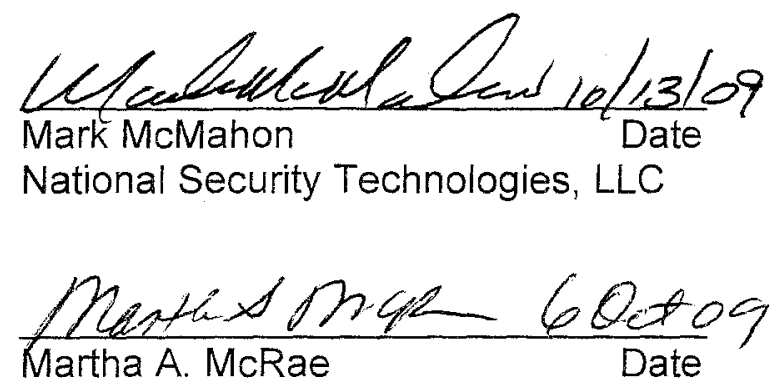

Desert Research Institute
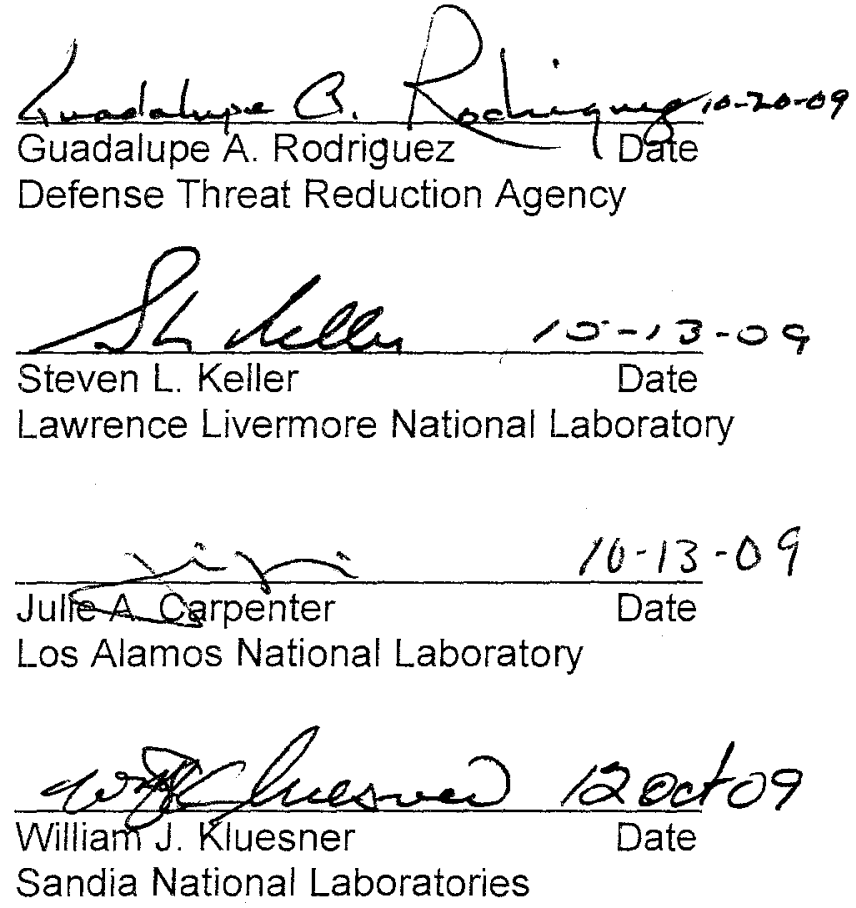

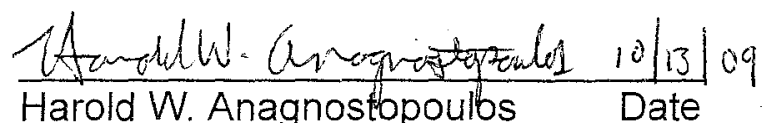
Navarro Nevada Environmental Services

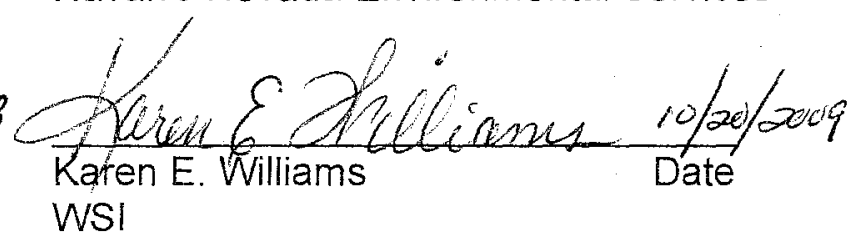


THIS PAGE INTENTIONALLY LEFT BLANK 
ALARA As Low As Reasonably Achievable ALI. Annual Limit on Intake

AMAD Activity Median Aerodynamic Diameter ANSI American National Standards Institute CAM . Continuous Air Monitor CED Committed Effective Dose CFR Code of Federal Regulations

DAC Derived Air Concentration

DOE U.S. Department of Energy

DOELAP. DOE Laboratory Accreditation Program DOT. U.S. Department of Transportation DRI Desert Research Institute GERT General Employee Radiological Training HEPA High-Efficiency Particulate Air ICRP International Commission on Radiation Protection LANL Los Alamos National Laboratory LLNL . Lawrence Livermore National Laboratory NIST National Institute of Standards and Technology

NNSA U.S. Department of Energy National Nuclear Security Administration

NNSA/NSO U.S. Department of Energy National Nuclear Security Administration Nevada Site Office

NNES. Navarro Nevada Environmental Services, LLC NPTEC Non-Proliferation Test and Evaluation Complex NRC U.S. Nuclear Regulatory Commission NSTec National Security Technologies, LLC NTS Nevada Test Site PC Protective Clothing PPE. Personal Protective Equipment 
RadCon Radiological Control

RAMATROL .Radioactive Materials Control

RCM .Radiological Control Manual $\mathrm{RCO}$ Radiological Control Organization

$\mathrm{RCT}$. Radiological Control Technician RGD Radiation-Generating Device RGDPA Radiation-Generating Device Program Administrator RMA Radioactive Material Area RPP. Radiation Protection Program RSPC Radiological Safety Prime Contractor RW-I Radiological Worker I RW-II Radiological Worker II

RWP Radiological Work Permit SAIC Science Application International Corporation SI. Systems International SNL Sandia National Laboratories SSE. Senior Site Executive SSPA. Sealed Source Program Administrator SWAC Site-Wide ALARA Committee

TED Total Effective Dose TO Tenant Organization URMA Underground Radioactive Material Area $W_{R}$ radiation weighting factor $\mathrm{Wt}$ tissue weighting factor 


\section{ACRONYMS}

\section{UNITS OF MEASUREMENT}

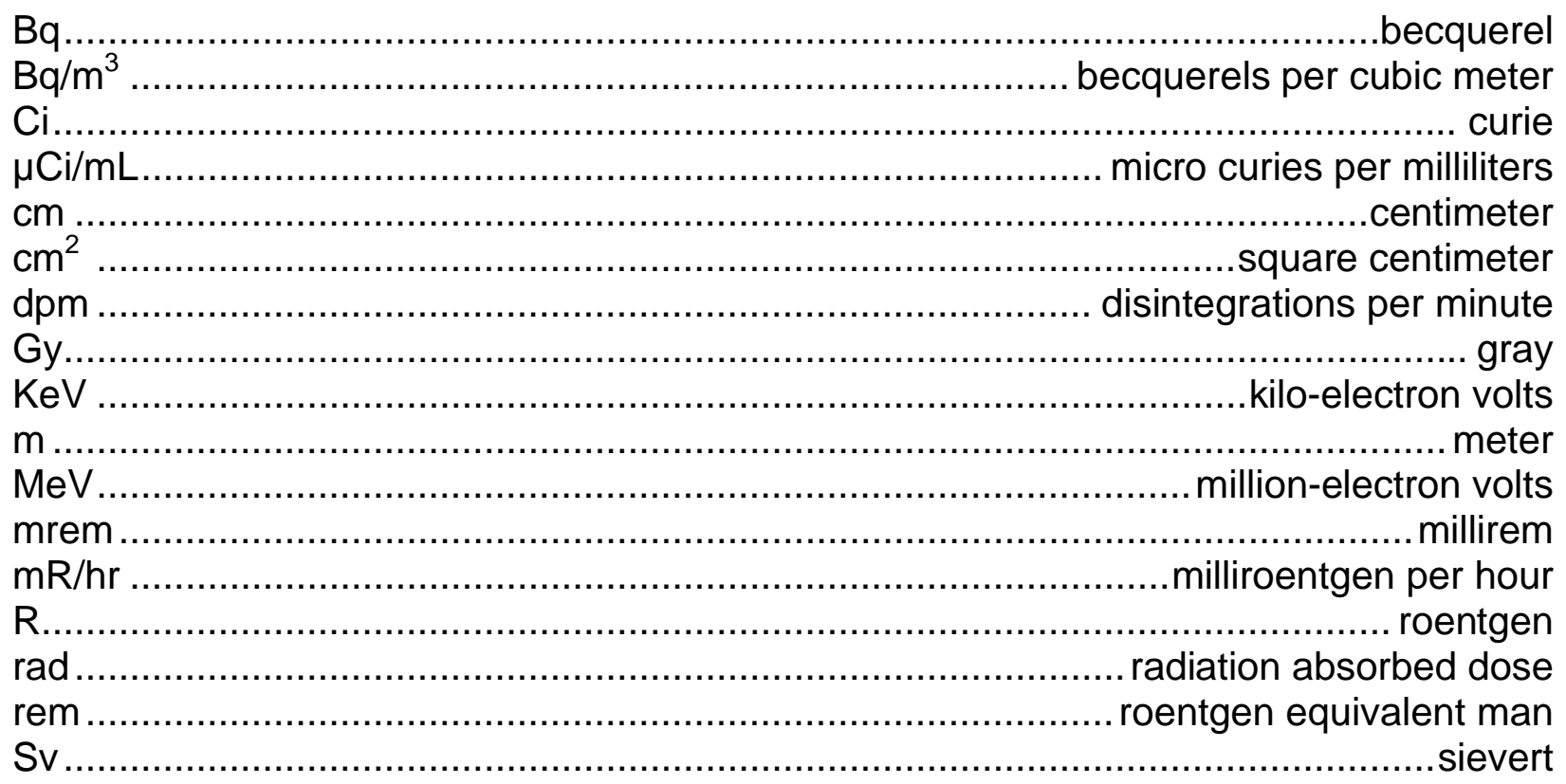


THIS PAGE INTENTIONALLY LEFT BLANK 
This manual contains the radiological control requirements to be used for all radiological activities conducted by programs under the purview of the U.S. Department of Energy (DOE) and the U.S. Department of Energy, National Nuclear Security Administration Nevada Site Office (NNSA/NSO). Compliance with these requirements will ensure compliance with Title 10 Code of Federal Regulations (CFR) Part 835, "Occupational Radiation Protection." Programs covered by this manual are located at the Nevada Test Site (NTS); Nellis Air Force Base and North Las Vegas, Nevada; Santa Barbara and Livermore, California; and Andrews Air Force Base, Maryland. In addition, fieldwork by NNSA/NSO at other locations is covered by this manual.

The NTS is located in Nye County, Nevada. The NTS is located approximately 105 kilometers (65 miles) northwest of Las Vegas. It is a remote facility that covers approximately 3,500 square kilometers (1,375 square miles) of land. The dimensions of the NTS vary from 46 to 56 kilometers (28 to 35 miles) in width (eastern to western border) and from 64 to 88 kilometers (40 to 55 miles) in length (northern to southern border).

The NTS is surrounded to the west, north, and east by additional thousands of acres of land withdrawn from the public domain for use as a protected wildlife range and as a military gunnery range. These public exclusion areas comprise the Nellis Air Force Range complex, previously designated as the Nellis Air Force Base Bombing and Gunnery Range, and the Tonopah Test Range. These two areas provide a buffer zone between the test areas and public lands administered by the Federal Bureau of Land Management.

The NTS has been the primary location for testing nuclear explosives in the continental United States since 1951. The topographical and geological characteristics of the NTS afford some protection to the inhabitants of the surrounding areas from potential radiation exposure as a result of release of radioactivity or contamination from nuclear testing operations. Historically, testing programs at the NTS have included atmospheric testing in the 1950s and early 1960s; underground testing in drilled, vertical holes and horizontal tunnels; earth-cratering experiments; and open air nuclear reactor and engine testing. Current activities include operating low-level radioactive and mixed waste disposal facilities for United States defense-generated waste, assembly and execution of subcritical experiments, assembly/disassembly of special experiments, the storage and use of special nuclear materials, performing criticality experiments, emergency responder training, surface cleanup and site characterization of contaminated land areas, environmental activity by the University system, and nonnuclear test operations, such as controlled spills of hazardous materials at the Hazardous Materials Spill Center. Currently, the major potential for occupational radiation exposure is associated with the burial of low-level radioactive waste and the handling of radioactive sources.

Remediation of contaminated land areas may also result in radiological exposures. 
The Tenant Organizations (TOs) that are responsible for conducting operations, according to this manual, include National Security Technologies, LLC (NSTec), Defense Threat Reduction Agency, Desert Research Institute, Lawrence Livermore National Laboratory, Los Alamos National Laboratory, Navarro Nevada Environmental Services, LLC, Sandia National Laboratories, and WSI. These organizations operate under this manual only when they are performing activities under the purview of NNSA/NSO.

To ensure that the appropriate procedures and policies are uniformly considered and applied by the TOs, one responsible TO is assigned radiological coordination responsibility by NNSA/NSO for a specific area or facility. Through the Maintenance and Operations contract, NSTec is currently responsible to NNSA/NSO for the coordination of the radiological safety aspects of NTS operations not specifically transferred to another organization.

NTS radiological coordination responsibility for a facility (building or complex) or project is delegated to the TO by NNSA/NSO through an activity agreement or a Real Estate/ Operations Permit.

This manual represents policies, guidelines, and best practices for implementing NTS radiation protection programs (RPPs) according to the requirements of 10 CFR 835 . This manual includes changes to implement updates to the regulation that was initially published in July of 2007 with required compliance within 3 years of publication. Therefore, some of the TOs may not have fully implemented this manual but have committed to do so by July 8,2010 . These programs provide protection for approximately 3,000 employees and visitors annually and include coverage for the onsite activities for both personnel and the environment. The personnel protection effort includes personnel bioassay programs, routine workplace air sampling, personnel monitoring, and programmatic and job-specific as low as reasonably achievable (ALARA) considerations, and DOE Laboratory Accreditation Program (DOELAP)accredited external and internal dosimetry. 


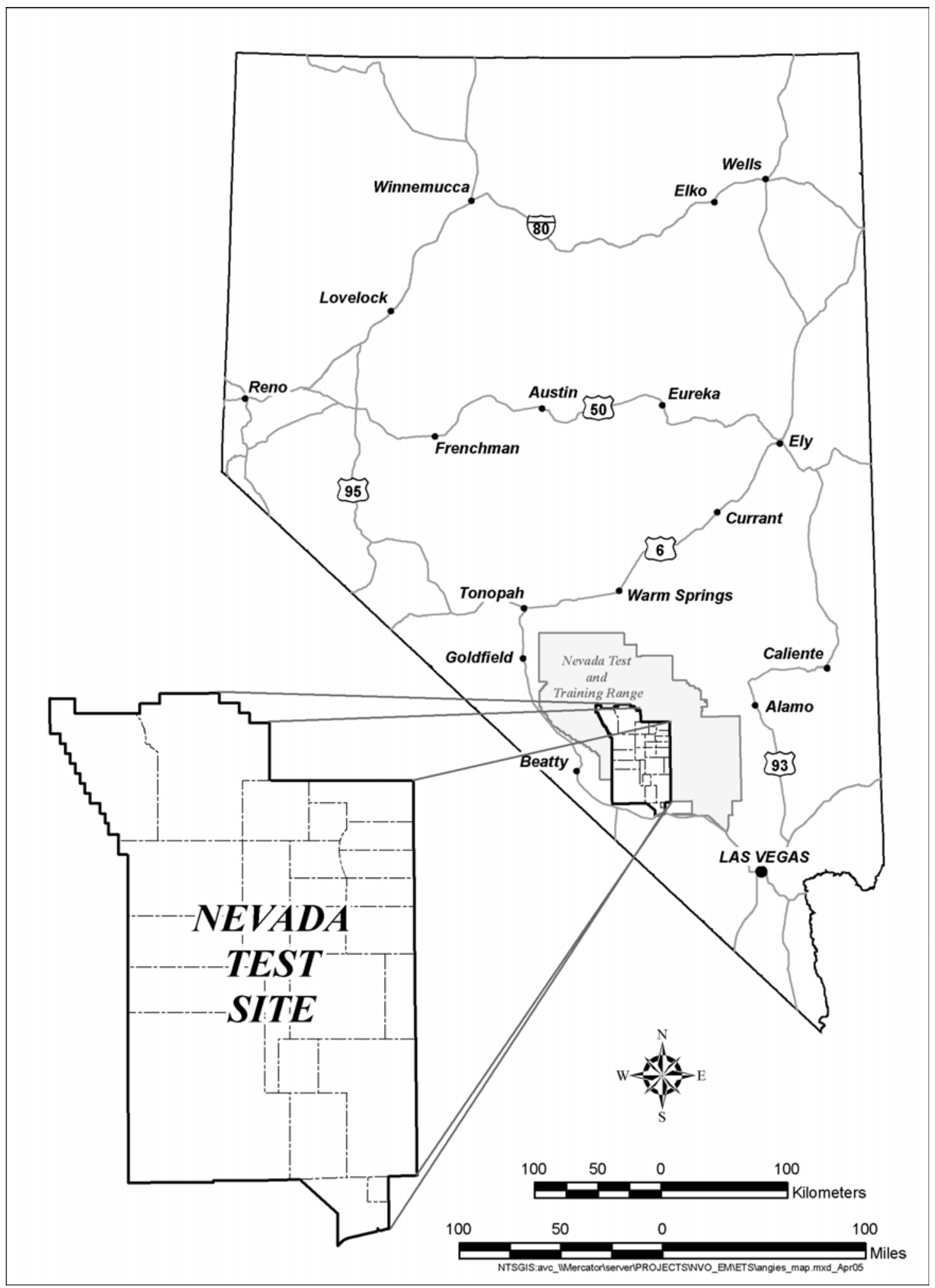

Figure 0-1. NTS Location 


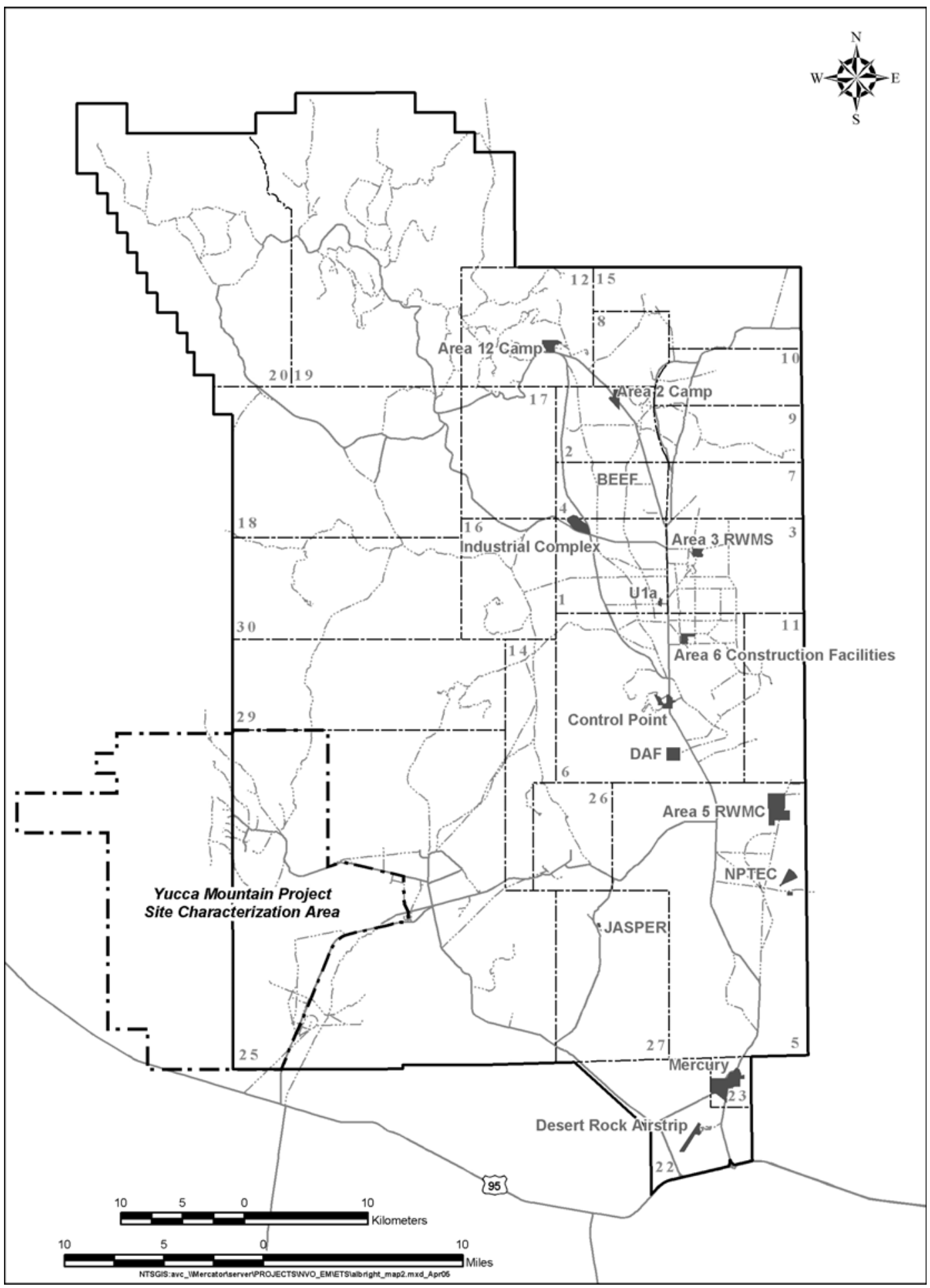

Figure 0-2. NTS Area Designations, Principal Facilities, and Testing Areas 
CHAPTER 1 COMMITMENT \& RESPONSIBILITY FOR RADIOLOGICAL CONTROL

TABLE OF CONTENTS

Article

Page

PART 1 NTS RADIOLOGICAL CONTROL MANUAL.............................................1-1

$111 \quad$ Radiological Control Policy ............................................................

$112 \quad$ Manual Applicability and Control ..................................................... 1-1

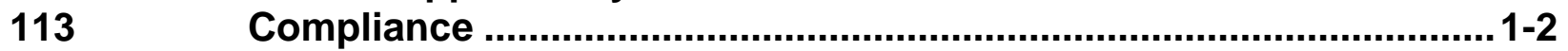

$114 \quad$ Site Specific Manual .......................................................................... 1-3

$116 \quad$ NNSA/NSO Tenant Organizations …................................................ 1-3

$118 \quad$ Integrated Safety Management .....................................................1-3

PART 2 LEADERSHIP IN RADIOLOGICAL CONTROL..................................... 1-3

$121 \quad$ Management Commitment .............................................................. 1-3

$123 \quad$ Radiological Worker Responsibilities.............................................1-3

$125 \quad$ Conduct of Radiological Operations............................................. 1-5

128 Facility Modifications and Radiological Design Considerations...... 1-5

PART 3 IMPROVING RADIOLOGICAL PERFORMANCE ................................... 1-6

$131 \quad$ Radiological Performance Goals.................................................. 1-6

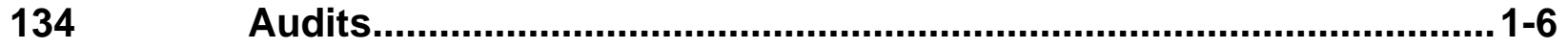

136 Internal Exposures......................................................................1-6

$138 \quad$ Site-Wide ALARA Committee …....................................................

PART 4 TENANT ORGANIZATION RADIOLOGICAL CONTROL ORGANIZATION 1-8

$141 \quad$ Radiological Control Organization ................................................... 1-8

$142 \quad$ Radiological Control Manager Qualifications ................................... 1-8

PART 5 NNSA/NSO MANAGEMENT ................................................................ 1-9

$156 \quad$ NNSA/NSO Employees in the Workplace ........................................1-9

$157 \quad$ Radiation Protection Programs .................................................... 1-9

Appendix 1A RADIOLOGICAL CONTROL MANAGERS' COUNCIL CHARTER... 1-10

Appendix 1B GENERIC ASSESSMENT PLAN FOR THE TENANT

ORGANIZATIONS' NEVADA TEST SITE RADIATION PROTECTION

PROGRAM 10 CFR 835.102, "INTERNAL AUDITS".

Appendix 1C SITE-WIDE ALARA COMMITTEE CHARTER..................................1-14 
THIS PAGE INTENTIONALLY LEFT BLANK 


\section{PART 1 NTS RADIOLOGICAL CONTROL MANUAL}

\section{Radiological Control Policy}

NNSA/NSO organizations are committed to providing a radiological control program that is consistent with DOE Policy DOE P 441.1, "Department of Energy Radiological Health and Safety Policy." The NNSA/NSO radiological control policy is intended to guide the actions of personnel involved in radiological work throughout NNSA/NSO facilities.

\section{AS LOW AS REASONABLY ACHIEVABLE}

Radiation exposure of the work force and public shall be controlled such that radiation exposures are maintained within acceptable limits and as far below these limits as is reasonably achievable. There should not be any occupational exposure of workers to ionizing radiation without the expectation of an overall benefit from the activity causing the exposure.

\section{OWNERSHIP}

Each person involved in radiological work is expected to demonstrate responsibility and accountability through an informed, disciplined, and cautious attitude toward radiation and radioactivity.

\section{Manual Applicability and Control}

This manual establishes unified practices for conducting radiological control activities by the NNSA/NSO TOs. The provisions of this manual are endorsed by the TOs as acceptable techniques, methods, and solutions for fulfilling their duties and responsibilities.

1. The provisions of this manual apply to DOE activities performed at NNSA/NSO sites or facilities. Any DOE activity as defined in 10 CFR 835 shall be planned and conducted in compliance with a documented RPP as approved by the NNSA.

2. The provisions of this manual also apply in those cases where contractors or subcontractors are used to conduct DOE radiological activities at non-NNSA/NSO sites or facilities and such organizations do not possess one of the following:

a. A U.S. Nuclear Regulatory Commission (NRC) license

b. An agreement state license

c. An appropriate state license, registration, or certification with a documented radiation protection program, plans, or procedures that provide a level of protection equivalent to that required by the DOE, NRC, or other appropriate federal standards 
In those cases at non-NNSA/NSO sites or facilities where a specific radiological activity is being conducted pursuant to an NRC or agreement state license, or appropriate state license, registration, or certification, the provisions of this manual are not binding to that activity.

3. The provisions of this manual are not binding upon activities at NNSA/NSO sites that are mandated by legislation to be performed pursuant to an NRC license, including activities certified by the NRC under Section 1701 of the Atomic Energy Act. Certain site-specific requirements of this manual, such as dosimetry, radioactive source registration and control, radiography, well logging, and NTS-specific training, may apply to NRC licensees.

4. This manual will be revised to incorporate changes in 10 CFR 835 and at other times, as deemed necessary by the Radiological Control (RadCon) Managers' Council.

5. Provisions of this manual also apply to National Response Asset Deployment activities when they are the lead organization responding to an emergency or conducting an activity in support of emergency response efforts. The provisions of this manual apply to those personnel and activities under NTS Radiological Safety Prime Contractor (RSPC) control. These provisions are not expected to cause compliance by other agencies or entities.

6. The RadCon Managers' Council, through the RSPC, is responsible for the creation, maintenance, revision, and controlled distribution of this manual.

\section{Compliance}

1. The word "shall" identifies those elements and requirements that are considered mandatory. If a TO wishes to implement an alternative approach for a "shall" statement that is not a requirement of 10 CFR 835, they shall submit the suggested alternative approach to the RadCon Managers' Council for review. The submittal shall contain the description of the alternative approach, the technical rationale and basis, and justification that the alternative will achieve equal or improved performance by employing equal or better techniques, solutions, or methods.

2. The word "should" means that the TO RadCon Managers' Council has evaluated the practice and found it is a proven remedy that implements basic requirements to support compliance. A TO may decide to follow an alternate approach in lieu of a should provision as long as they provide documentation that the alternative will achieve equal or improved performance by employing equal or better techniques, solutions, or methods and demonstrates compliance with the underlying basic requirements.

3. Written procedures shall be developed and implemented as necessary to ensure compliance with 10 CFR 835. 


\section{Site Specific Manual}

This is a site specific manual endorsed by the senior site executives that implements the requirements of the NTS RPP and invokes the applicable provision of the DOE RadCon Standard.

\section{NNSA/NSO Tenant Organizations}

1. The TO RadCon Managers should meet as the RadCon Managers' Council at least quarterly to discuss and review issues relevant to radiological control at NNSA/NSO locations. The RadCon Manager's Council Charter is included as Appendix 1A.

2. Each TO RadCon Manager should meet with their Senior Site Executive (SSE) to inform top management of the status and issues relating to radiological control implementation.

\section{Integrated Safety Management}

TOs will implement Integrated Safety Management in accordance with contract requirements.

\section{PART 2 LEADERSHIP IN RADIOLOGICAL CONTROL}

\section{Management Commitment}

1. By approving this manual, SSEs confirm commitment to the radiological control program as contained herein. Management commitment and support are demonstrated by allocating sufficient personnel and other resources, and providing training to ensure workers are qualified for their assigned duties.

2. Managers at all levels should ensure that orientation, training, and indoctrination reinforce rules and guidelines for each worker to minimize radiation exposure and control radiological conditions.

3. Managers at all levels should hold workers and their supervisors accountable for radiological control performance.

\section{Radiological Worker Responsibilities}

Radiological workers shall understand that proper radiological control is an integral part of their duties. A poster that displays the workers' responsibilities should be produced and displayed at appropriate access points and work areas. The following radiological control rules are applicable for radiological work: 


\section{TO MINIMIZE YOUR RADIATION EXPOSURE AND CONTROL RADIOACTIVE MATERIAL, OBSERVE THE FOLLOWING RULES}

\section{OBEY}

- Posted, written, and verbal radiological control instructions and procedures, including instructions on Radiological Work Permits (RWPs).

- "Evacuate" and "stop work" orders from radiological control personnel promptly.

\section{DO NOT}

- Loiter in radiation areas.

- Smoke, eat, drink, or chew in Contamination Areas, High Contamination Areas, and Airborne Radioactivity Areas.

\section{BE SURE TO}

- Wear personnel monitoring devices where required by RWPs, signs, procedures, or by radiological control personnel. Report immediately the loss, damage, or unexpected exposure of personnel monitoring devices or off-scale readings of self-reading dosimeters to the responsible Radiological Control Organization.

- Keep track of your radiation exposure status and avoid exceeding radiological Administrative Control Levels.

- Wear personal protective equipment (PPE) and protective clothing (PC) properly whenever required by RWPs or postings.

- Minimize the spread of radioactive spills and promptly notify the appropriate personnel of all spills.

- Avoid contact of skin, clothing, and equipment with contaminated surfaces.

- Place contaminated tools, equipment, and solid waste items on disposable surfaces, such as plastic sheets, when not in use.

- Notify radiological control personnel of alarming or faulty radiological control equipment.

- Notify radiological control personnel of offsite occupational radiation exposures so that worker dosimetry records can be updated.

\section{BEFORE ENTERING AREA}

- Assure that you are mentally alert and in physically sound condition.

- Limit the amount of material taken into contaminated areas to minimize radioactive waste and future decontamination.

- Have necessary materials and equipment on hand to complete your task, thereby minimizing time and exposure.

- Notify radiological control personnel of the presence of open wounds, sores, or rashes before entering an area where contamination exists and exit immediately if a wound occurs while in such an area.

\section{UPON LEAVING AREA}

- Properly remove PPE and PC to minimize the spread of contamination.

- Frisk or be frisked for contamination when entering an uncontaminated area after exiting posted Contamination, High Contamination, or Airborne Radioactivity Areas and notify radiological control personnel when contamination is found. 


\section{Conduct of Radiological Operations}

1. This standard is consistent with the provisions of DOE Order DOE O 5480.19, "Conduct of Operations Requirements for DOE Facilities." The concepts of all chapters of DOE O 5480.19 apply to the conduct of radiological control activities.

2. The principles of Integrated Safety Management shall be integrated into the planning, scheduling, and conduct of radiological work. The TO Radiological Control Organization (RCO) should be involved in planning such work.

3. Supervisors should be technically knowledgeable and should ask questions of the work force concerning radiological work details to verify worker comprehension.

4. Line managers should periodically monitor work areas to observe personnel at work and to identify radiological deficiencies and concerns.

5. Managers, supervisors, and workers should be involved in developing accurate, clear, written procedures for performing radiological work. If, during the use of procedures, a written requirement cannot be responsibly followed, the work should be stopped and guidance obtained.

6. Supervisors and managers should encourage the work force to identify radiological control deficiencies and concerns. Prompt action should be taken to address and correct identified issues to prevent recurrence. Retraining, indoctrination, and procedure review are useful in addressing these issues. Lessons Learned should be communicated to TO RCOs and other appropriate elements of the work force.

7. Managers and supervisors should establish working conditions that encourage improved radiological control. Work conditions should be considered in planning work.

8. Subcontractors and subcontracted employees should be treated the same as TO staff in the area of radiological matters, should have comparable training, and should meet the same requirements and expectations.

\section{Facility Modifications and Radiological Design Considerations}

1. General design criteria for new facilities and major modifications to existing facilities are contained in 10 CFR 835 and DOE O 420.1B, "Facility Safety." In addition, the following radiological control design criteria are provided for new facilities and major modifications to existing facilities:

a. For areas of continuous occupancy (2,000 hours per year), the design objective shall be to maintain the average exposure levels ALARA and shall not exceed 0.5 mrem per hour. 
b. If occupancy is not continuous, the design objective shall be to maintain doses ALARA and shall not exceed 20 percent of the occupational dose limits provided in Table 2-1.

c. Components should be selected to minimize the buildup of radioactivity.

d. Controlling contamination should be achieved by containing radioactive material.

e. Efficiency of maintenance, decontamination, operations, and decommissioning shall be maximized.

f. Support facilities should be provided for donning and removing PC and for personnel monitoring, when required.

2. Facilities currently under construction should be evaluated and the above criteria applied where practical.

\section{PART 3 IMPROVING RADIOLOGICAL PERFORMANCE}

\section{Radiological Performance Goals}

Each TO should establish radiological control goals at the project level, if they provide opportunities to improve radiological performance (e.g., collective dose, skin/personal clothing contamination, radioactive waste generation).

Line Management should participate in establishing and implementing these goals.

\section{Audits}

Internal audits of the radiological control program shall be conducted such that over a 36-month period, all functional elements of 10 CFR 835 are assessed for program performance, applicability, content, and implementation. The TO RadCon Manager may extend the time interval by a period not to exceed 30 days. The "Generic Assessment Plan for the Tenant Organizations' Nevada Test Site Radiation Protection Program 10 CFR 835.102, "Internal Audits," is included as Appendix 1B.

\section{Internal Exposures}

Control and prevention of internal exposure, particularly from long-lived radionuclides in the workplace, present special challenges to a radiological control program and warrant particular attention. Factors requiring management attention include the following:

- Workers may be exposed to unanticipated levels of elevated airborne radioactivity. The time required to collect representative airborne radioactivity samples and to determine the airborne concentration of radionuclides may contribute to worker intakes of radioactivity.

- If controls fail, internal depositions of radionuclides can occur in a short period of time. 
- The continued exposure of workers to airborne radioactivity over extended periods of time can create worker concerns.

- Doses from some radionuclides taken into the body are difficult to measure. Although some radionuclides, such as cesium and tritium, can be readily measured at levels that produce only a few millirem, some long-lived radionuclides, such as plutonium, may require years for accurate measurements of hundreds of millirem.

- Medical intervention, such as the administration of blocking and chelating agents, to mitigate internal deposition may add risks by introducing additional chemicals into the body.

- Sampling of body excretions and whole body or organ counting techniques may encourage worker perceptions of internal exposure significance.

- Administration of internal dose assessment is costly in dollars and worker time. Control and analysis of samples are also more complicated and time consuming than the elements of external dosimetry.

- Use of respiratory protection devices imposes additional physical stresses upon participating workers.

- The overall optimization of total dose - sum of both external and internal doses.

The hierarchy of controls required to control internal exposures is provided in Article 316.

\section{Site-Wide ALARA Committee}

It is the policy of the NNSA/NSO TOs to conduct their operations in a manner to protect the health and safety of employees, visitors, and members of the public. Each user organization will present annual ALARA goals for their organization to the Site-Wide ALARA Committee (SWAC).

It is the policy of each user organization that those significant radiological operations conducted jointly by several contractors will benefit from peer review toward the ALARA goal of improving radiation safety and minimizing radiation exposure and releases to the environment. The organization that has radiological coordination of a project or facility has the responsibility to make a presentation to the SWAC for review and should abide by the guidance provided by the Committee. The SWAC Charter is included as Appendix 1C. 


\section{PART 4 TENANT ORGANIZATION RADIOLOGICAL CONTROL ORGANIZATION}

NNSA/NSO TOs maintain RCOs or entities that exercise technical and programmatic oversight of radiological work or activities under their purview and provide relevant support to line managers and workers. To function effectively, the RCO should be independent of the line organizational element responsible for production, operation, or research activities and should have an equivalent reporting level.

\section{Radiological Control Organization}

1. Each RCO is represented by a designated TO RadCon Manager under the authority of the TO's SSE. To ensure independence in making correct radiological control decisions, the RCO should be accountable to the TO RadCon Manager. Consistency of radiation control is critical and is facilitated through the RadCon Managers' Council.

2. RadCon personnel should monitor adherence to the NTS RCM and be available to the facility line manager for radiological support to the work force.

3. The RSPC shall provide the following:
a. Survey and swipe-counting services
b. Personnel decontamination facilities
c. Radiological Control Technician (RCT) and site-monitoring services
d. Fencing, posting, and inventory of areas
e. External and internal dosimetry services
f. Radiological instruments, maintenance, and calibration services
g. Respiratory protection services
h. Radiological safety training
i. Inventory of accountable sealed sources

\section{Radiological Control Manager Qualifications}

1. The TO RadCon Managers should be experienced professionals in radiological control and be familiar with the design features and operations of their facilities that affect the potential for exposure of personnel to radiation.

2. The TO RadCon Managers should have the technical competence and experience to establish radiological control programs and the supervisory capability to direct the implementation and maintenance of radiological control programs.

3. Individuals responsible for developing and implementing measures necessary for ensuring compliance with the requirements of 10 CFR 835 shall have the appropriate education, training, and skills to discharge these responsibilities. 


\section{PART 5 NNSA/NSO MANAGEMENT}

\section{NNSA/NSO Employees in the Workplace}

NNSA/NSO employees are subject to and shall adhere to the provisions of this manual.

\section{Radiation Protection Programs}

1. Each NNSA/NSO TO shall submit an RPP meeting the requirements of $10 \mathrm{CFR}$ 835.101 to NNSA/NSO which describes radiological work activities and radiological protection measures within the scope of its program.

2. The content of each RPP shall:

a. Address, but shall not necessarily be limited to, each requirement in 10 CFR 835.

b. Include plans, schedules, and other measures for achieving compliance with the regulations within 10 CFR 835.

c. Specify the existing and/or anticipated operational tasks that are intended to be within the scope of the RPP.

d. Be commensurate with the nature of the activities performed and shall include formal plans and measures for applying the ALARA process to occupational exposure.

3. An update of the RPP shall be submitted to NNSA/NSO:

a. Whenever a change or addition to the RPP is made.

(1) Changes, additions, or updates to the RPP may become effective without prior approval of NNSA/NSO, as appropriate, only if the changes do not decrease the effectiveness of the RPP and the $\mathrm{RPP}$, as changed, continues to meet the requirements of $10 \mathrm{CFR}$ 835.

(2) Proposed changes that decrease the effectiveness of the RPP shall not be implemented without submittal to and subsequent approval by NNSA/NSO.

b. Before the initiation of a task not within the scope of the RPP. Except as provided in Article 157.3.a.(1), any task outside the scope of an RPP shall not be initiated until an update of the RPP is approved by NNSA/NSO.

c. Within 180 days of the effective date of any modification to 10 CFR 835 .

4. An initial RPP or an update shall be considered approved 180 days after its submission unless rejected by NNSA/NSO at an earlier date.

5. The NNSA/NSO may direct modifications to an RPP. 


\section{Appendix 1A}

\section{RADIOLOGICAL CONTROL MANAGERS' COUNCIL CHARTER}

\section{PURPOSE}

Article 114 of the U.S. Department of Energy (DOE) Standard DOE-STD-1098-2008, "Radiological Control," states that where there are multiple contractors for one facility there should be a common manual that addresses contractor-specific guidance endorsed by each contractor's Senior Site Executive (SSE). Toward that end, representatives of the Nevada Test Site (NTS) have developed the NTS Radiological Control Manual (RCM). Radiological Control (RadCon) Managers from each Tenant Organization (TO) are responsible for implementation of, and must approve revisions to, the RCM. The TO RadCon Managers have chartered the RadCon Managers' Council (Council) according to Article 116 of the RCM.

\section{CHARTER}

The Council shall be the formal forum of TOs within the U.S. Department of Energy, National Nuclear Security Administration Nevada Site Office (NNSA/NSO) to manage common radiation safety and RCM matters at the NTS.

The Council will:

a) Update and revise the RCM and obtain SSE concurrence.

b) Resolve radiological issues when an operation involves more than one TO.

c) Formulate, prioritize, and develop consistent radiological policies and controls for TOs.

d) Support internal audits of TO radiological safety programs as required by 10 CFR 835 .

3. ORGANIZATION

Voting membership shall consist of TO RadCon Managers or their designees from NTS users. NNSA/NSO representatives and DOE may participate as nonvoting members of the Council. SSEs, contractor managers, and other individuals may be requested or invited to participate in meetings.

A quorum consisting of greater than half of the voting members must be present to conduct an official meeting. All decisions will be approved by consensus except as stated below.

The Chair and Co-Chair shall be designated annually by simple majority agreement of the voting members at the last meeting of the calendar year.

\section{RESPONSIBILITIES}

RadCon Managers or designees are responsible for:

- Attending meetings

- Communicating with their individual SSEs on the activities and statements from the Council

- Obtaining concurrence and signatures of their individual SSE on Council actions when required

- Participating in review and revision of the RCM

- Participating in review and resolution of site-wide radiological issues

- Participation in review and development of technical basis documents

- Scheduling and implementing the triennial assessment plan for applicable organizations

The Chairperson is responsible for:

- Ensuring that meetings are held at least quarterly

- Ensuring that meeting announcements, agendas, and meeting minutes are distributed to each Council member

- Transferring records generated by the Council to the NTS Radiological Safety Prime Contractor (RSPC)

- Coordinating Council functions among members

\section{RECORDS}

The NTS RSPC is responsible for managing and retrieving documents and records generated by the Council. 


\author{
Appendix 1B \\ GENERIC ASSESSMENT PLAN FOR THE TENANT ORGANIZATIONS' NEVADA TEST SITE \\ RADIATION PROTECTION PROGRAM 10 CFR 835.102, "INTERNAL AUDITS"
}

\title{
1. SCOPE
}

Title 10 CFR 835.102, "Internal Audits," states, "Internal audits of the radiation protection program, including examination of program content and implementation, shall be conducted through a process that ensures that all functional elements are reviewed no less frequently than every 36 months." To fulfill this requirement, assessments are commissioned by the Nevada Test Site (NTS) Tenant Organization's (TO's) Radiological Control (RadCon) Managers' Council (Council) through the NTS Radiation Protection Program (RPP). Each of the TOs participating in the RPP agrees to perform assessments using members selected by the Council. The assessment scope will include lower-tiered implementing documents, observations of job sites, and interviews to verify implementation of those requirements. The Assessment Team Leader and the RadCon Manager of the TO under assessment will agree upon the assessment start date. Each RadCon Manager shall keep the Senior Site Executive of his or her organization apprised of the assessment schedule and results.

\section{ASSESSMENT APPROACH}

The assessment of each functional element will encompass all TOs contiguously, and will be conducted according to an attached assessment schedule developed, approved, and modified by the Council. The Council will develop and approve a schedule for each three year assessment period. The schedule will establish the functional elements(s) to be assessed each year. Each assessment will continue to assemble observations and facts throughout the year and will not terminate these activities prior to November 30 each year. The schedule will ensure that functional element assessments do not exceed the 36 month time frame.

a) An Assessment Team will be appointed for each functional element. Each Assessment Team will utilize checklists developed for the functional element of the RPP under assessment. The checklists will identify, for each 10 CFR 835 requirement, the applicable implementation reference documents from each TO's RPP Appendix or crosswalk. The compliance assessment of 10 CFR 835 requirements within each functional area will be conducted in the following phases:

i) Phase 1. Articles of the NTS Radiological Control Manual identified as implementation reference documents for a 10 CFR 835 requirement within the functional area will be evaluated for completeness and applicability to the requirement on the basis that they are self-implementing.

ii) Phase 2. Procedures identified by each TO as evidence of compliance will be evaluated for applicability and compliance with the 10 CFR 835 requirements.

iii) Phase 3. Onsite observations and interviews will be conducted, if activities are available, to determine if the RPP and each TO's supporting documents are implemented in the field. The RadCon Manager of the TO under evaluation will be asked to coordinate site visits to radiological operations and to facilitate interviews.

b) If requested by the RadCon Manager of the TO under assessment, an informal out briefing will be conducted with the site operations line manager after each interview session or site visit. Concerns or findings that need immediate action in the view of the Assessment Team will be brought to the attention of the RadCon Manager of the TO under assessment.

c) Findings and concerns outside the scope of the assessment may be discussed by the Assessment Team and the TO under assessment, but will not be documented in the report unless requested by that organization.

d) Disputes between the TO and the Assessment Team will be resolved by majority vote of the Council. Dissenting opinions will be documented in the final assessment report.

e) Assessment findings concerning individual TOs will be held in confidence by the Council and Assessment Team members. Determination of reportability of Price Anderson Amendments Act noncompliance will remain the responsibility of the applicable TO.

f) Compliance will be evaluated by the following criteria:

i) Does the information included in the TO's supporting documentation meet the intent and scope of the 10 CFR 835 requirements?

ii) Do the documents cited by the TO implement the requirements of 10 CFR 835 ? 


\section{Appendix 1B (Continued)}

iii) Do onsite observations and interviews indicate that the requirements as stated in the TO's RPP Appendix are implemented at work locations?

g) Findings and concerns will be re-addressed in subsequent assessments, if requested by the TO.

\section{ASSESSMENT TEAM MEMBERS}

The Assessment Team will consist of at least two members, one of which will be designated the Lead, and will be determined by the Council prior to the assessment. At a minimum, one team member will be from the Council.

\section{ASSESSMENT PROCESS}

a) Pre-assessment team meeting. The Assessment Team Leader will meet with the Assessment Team to discuss the scope of the assessment and assign duties.

b) In-brief with TO under assessment. The Assessment Team will meet with the TO representatives to establish the assessment parameters and review TO compliance documentation.

c) Council briefings. The Assessment Team will brief the Council at established meetings on the status of assessments (upcoming assessments, status of ongoing assessments, etc.).

d) Assessment Team observations. The TO RadCon Manager will facilitate interviews and coordinate onsite observations by the Assessment Team at radiological areas, radioactive source storage areas, and radioactive material storage areas controlled at the NTS by the TO (as applicable). Assessment Team members will obey all TO safety and administrative requirements for the areas that they enter.

e) Mitigation of findings and concerns. The Assessment Team will be available to meet with the TO RadCon Manager to mitigate findings and concerns and discuss compliance issues as they arise.

f) Closing briefing with TO. The Assessment Team will brief the TO on the assessment findings and concerns at the close of the assessment. Changes to the content of the final Assessment Report before publication will be made only with concurrence of the Assessment Team and the TO being assessed.

g) Preparation of the Assessment Report. The Assessment Team will prepare a formal Assessment Report, which is presented to the Council. An electronic version of the Assessment Report template may be obtained from the NTS Radiation Safety Prime Contractor (RSPC).

h) Issuing the Assessment Report. The Council will approve the final Assessment Report. The Assessment Team Leader will distribute the final Assessment Report by letter or memorandum to the RadCon Managers.

\section{PRE-ASSESSMENT BACKGROUND MATERIAL}

a) The TO under assessment should provide the Assessment Team Leader with the names of the personnel in key positions requested to be interviewed by the Assessment Team.

b) The TO under assessment should be prepared to provide requested information to each Assessment Team member at the in briefing.

c) The Assessment Team Leader will provide the TO RadCon Manager with the assessment dates, Assessment Team members, and checklist two weeks prior to the in briefing.

6. POINT OF CONTACT

Questions concerning the assessment shall be directed to the Assessment Team Leader or the Council.

7. RECORDS

a) The following records are generated by the assessment process:

i) Checklist

ii) Assessment Report

b) The NTS RSPC will maintain the internal assessment records.

c) Assessment Report records will be made available to all users of common NTS RSPC services. 


\section{Appendix 1B (Continued)}

\section{ATTACHMENT A:}

\section{Functional Elements}

DOE Guide 441.1-1C, "Radiation Protection Programs Guide for use with Title 10, Code of Federal Regulations, Part 835, Occupational Radiation Protection," Section 3.2, "Organization and Administration," defines the following Functional Elements:

\begin{tabular}{|c|c|c|c|c|}
\hline $\begin{array}{l}\text { Element } \\
\text { Number }\end{array}$ & Functional Element & $\begin{array}{c}10 \text { CFR } 835 \\
\text { Requirement }\end{array}$ & $\begin{array}{l}\text { Assessment Scope by } \\
\text { Functional Element }\end{array}$ & $\begin{array}{l}\text { Assessment } \\
\text { Number }\end{array}$ \\
\hline 1 & $\begin{array}{l}\text { Organization and } \\
\text { Administration }\end{array}$ & $\begin{array}{l}\text { Subpart B }(101,102,103, \\
104)\end{array}$ & $\begin{array}{l}\text { Assessment } 1 \\
\text { Element } 1\end{array}$ & A-1 \\
\hline 2 & ALARA Program & $\begin{array}{l}\text { 101c, Subpart K (1001, } \\
\text { 1002, 1003) } \\
\text { Subpart C (206) }\end{array}$ & $\begin{array}{l}\text { Assessment } 2 \\
\text { Element 2, 6a }\end{array}$ & A-2 \\
\hline 3 & External Dosimetry Program & $401 a, 402 a, 402 b$ & $\begin{array}{l}\text { Assessment } 3 \\
\text { Element 3, 5a, 7, } 8\end{array}$ & $A-3$ \\
\hline 4 & Internal Dosimetry Program & $401 a, 402 c, 402 d$ & $\begin{array}{l}\text { Assessment } 4 \\
\text { Element } 4,5 b \\
\end{array}$ & A-4 \\
\hline $5 a$. & Area Radiation Monitoring & $401 a$ & A-3 & $A-3$ \\
\hline 5.b. & $\begin{array}{l}\text { Airborne Radioactivity } \\
\text { Monitoring, and Respiratory } \\
\text { Protection }\end{array}$ & $209,401 a, 403$ & A-4 & $A-4$ \\
\hline 5.c. & $\begin{array}{l}\text { Contamination Monitoring } \\
\text { and Control }\end{array}$ & $\begin{array}{l}\text { 401a, Subpart L (1101, } \\
\text { 1102) }\end{array}$ & $\begin{array}{l}\text { Assessment } 5 \\
\text { Element } 5 \mathrm{c}, 6 \mathrm{e}\end{array}$ & A-5 \\
\hline 5.d. & $\begin{array}{l}\text { Instrument Calibration and } \\
\text { Maintenance }\end{array}$ & $401 b$ & $\begin{array}{l}\text { Assessment } 6 \\
\text { Element 5d }\end{array}$ & A-6 \\
\hline 6.a. & Radiological Work Planning & 501d, 1001b, 1003 & A-2 & A-2 \\
\hline 6.b. & Entry and Exit Controls & Subpart $F(501,502)$ & $\begin{array}{l}\text { Assessment } 7 \\
\text { Element } 6 \mathrm{~b}, 6 \mathrm{c}, 6 \mathrm{~d}\end{array}$ & A-7 \\
\hline 6.c. & Radiological Work Controls & Subpart F, 1003 & A-7 & A-7 \\
\hline 6.d. & Posting and Labeling & $\begin{array}{l}\text { Subpart G }(601,602,603 \\
604,605,606)\end{array}$ & A-7 & A-7 \\
\hline 6.e. & $\begin{array}{l}\text { Release of Materials and } \\
\text { Equipment }\end{array}$ & 1101 & $A-5$ & A-5 \\
\hline 6.f. & $\begin{array}{l}\text { Sealed Radioactive Source } \\
\text { Accountability and Control }\end{array}$ & Subpart M $(1201,1202)$ & $\begin{array}{l}\text { Assessment } 8 \\
\text { Element } 6 f\end{array}$ & A-8 \\
\hline 7. & $\begin{array}{l}\text { Emergency Exposure } \\
\text { Situations }\end{array}$ & 1301,1302 & A-3 & A-3 \\
\hline 8. & Nuclear Accident Dosimetry & 1304 & A-3 & A-3 \\
\hline 9. & Records & $\begin{array}{l}\text { Subpart H }(701,702,703, \\
704)\end{array}$ & $\begin{array}{l}\text { Assessment } 9 \\
\text { Element } 9,10\end{array}$ & A-9 \\
\hline 10. & Reports to Individuals & Subpart I (801) & A-9 & A-9 \\
\hline 11. & Radiation Safety Training & Subpart I (901) & $\begin{array}{l}\text { Assessment } 10 \\
\text { Element } 11\end{array}$ & A-10 \\
\hline
\end{tabular}


Appendix 1C

SITE-WIDE ALARA COMMITTEE CHARTER

The As Low As Reasonably Achievable (ALARA) process is applied to occupational exposure to personnel and radiological releases to the environment through the implementation of 10 CFR 835. The ALARA concept also applies to the environmental program that establishes control and management of releases of radioactive material and radiation exposures of members of the public to radiation levels that are ALARA.

Reducing radiation exposures to levels that are ALARA has long been the goal at the Nevada Test Site (NTS). It is the policy of the U.S. Department of Energy, National Nuclear Security Administration Nevada Site Office Tenant Organizations (TOs), contractors, subcontractors, and users to conduct their operations, tests and test support, laboratory services, and research in a manner to protect the health and safety of employees, visitors, and members of the public. We are committed, in all of our activities, to reduce any safety or health risks associated with radioactive materials and ionizing radiation to levels that are ALARA.

The following principles form the core fundamentals of the ALARA Program at the NTS:

- Radiological and other safety design considerations will be applied to the design and modification of facilities to reduce exposure to individuals and releases to the environment.

- Radiological controls will be carried out during operations, testing, maintenance, research, and other support activities to minimize personnel exposures and releases to the environment.

- Monitoring of radioactive material and radiation (personnel and environmental), together with measurements of worker radiation dose, will be performed to verify and document that doses are being maintained ALARA.

It is recognized that each user organization at the NTS has needs that are specific and critical to its programs. Therefore, no single set of criteria can be prescribed for achieving all ALARA goals at the NTS. However, each user organization will present annual ALARA goals for their organization to the Site-Wide ALARA Committee (SWAC).

It is the policy of each user organization at the NTS that those significant radiological operations conducted jointly by several contractors will benefit from peer review toward the ALARA goal of improving radiation safety and minimizing radiation exposure and releases to the environment. The organization that has radiological coordination of a project or facility has the responsibility to make a presentation to the SWAC for review and should abide by the guidance provided by the Committee.

The SWAC consists of representatives from each of the TOs.

Members of the SWAC are appointed by, and report to, their Senior Site Executives on matters pertaining to the NTS radiological control program. Membership should include senior line managers, senior representatives from technical support functions, and radiological control personnel. Members of the SWAC are assigned coordination responsibilities to implement the policy of this Committee. The responsibilities of SWAC members are as follows:

- Review prospective radiological operations common to more than one TO, critique the radiation safety of the operation, and establish worker exposure levels and dose goals for the operation.

- Act as a review and advisory group, available upon request, to review ALARA-related topics (e.g., Radiological Work Permits, designs, plans, training, operations, summary data, and procedures) and major sources of radiation exposure with the intent of identifying means for their reduction and trending.

- Establish methods and guidelines for user organizations to improve progress toward minimizing radiation exposure to personnel and radiological releases to the environment.

- Establish and review the ALARA goals and publish these goals annually in the SWAC minutes.

- $\quad$ Ensure the goals are integrated into operations and activities.

- Conduct meetings of the SWAC at least semi-annually; ensuring that minutes include actions taken, issues discussed, and resolutions.

- Elect the chairperson of the SWAC from one of the designated representatives. 


\section{TABLE OF CONTENTS}

$\underline{\text { Article }}$

Page

PART 1 ADMINISTRATIVE CONTROL LEVELS AND DOSE LIMITS ..................... 2-1

211 Administrative Control Level ............................................................ 2-1

213 Radiological Worker Dose Limits ....................................................... 2-1

214 Members of the Public Dose Limits ........................................... 2-3

215 Embryo/Fetus Dose Limits................................................................ 2-3

PART 2 CONTAMINATION CONTROL AND CONTROL LEVELS ........................... 2-4

222 Contamination Control Levels............................................................2-4

223 Airborne Radioactivity Control Levels............................................. 2-6

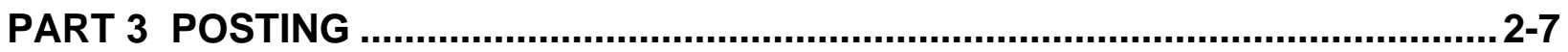

231 Posting Requirements......................................................................... 2-7

232 Posting Controlled Areas .................................................................. 2-8

233 Posting Radiological Buffer Areas ..................................................... 2-9

234 Posting of Radiation Areas, High Radiation Areas, and Very High Radiation Areas ......................................................................... 2-10

235 Posting Contamination, High Contamination, and Airborne Radioactivity Areas.............................................................................. 2-10

236 Posting Radioactive Material Areas ................................................ 2-11

237 Posting Underground Radioactive Material Areas...........................2-12

238 Posting Entombed Radioactive Material Areas...............................2-12

Appendix 2A GUIDELINES FOR CONTROL OF EMERGENCY EXPOSURES ..... 2-13

Appendix 2B TISSUE WEIGHTING FACTORS FOR VARIOUS ORGANS AND TISSUES 
THIS PAGE INTENTIONALLY LEFT BLANK 


\section{PART 1 ADMINISTRATIVE CONTROL LEVELS AND DOSE LIMITS}

\section{Administrative Control Level}

NNSA/NSO TOs have established the annual Administrative Control Level at 500 mrem total effective dose (TED).

1. No individual shall be allowed to exceed the Administrative Control Level without the prior approval of the TO RadCon Manager and TO SSE.

2. Approval by the appropriate Secretarial Officer or designee should be obtained prior to allowing an individual to exceed 2,000 millirem in a calendar year.

\section{Radiological Worker Dose Limits}

1. Except for emergency exposures authorized according to 10 CFR 835.1302, the occupational dose received by general employees shall be controlled such that the following limits are not exceeded in a year:
a. A TED of 5 rem (0.05 Sv)
b. The sum of the equivalent dose to the whole body for external exposures and the committed equivalent dose to any organ or tissue other than the skin or the lens of the eye of 50 rem (0.5 Sv)
c. An equivalent dose to the lens of the eye of 15 rem (0.15 Sv)
d. The sum of the equivalent dose to the skin or to any extremity for external exposures and the committed equivalent dose to the skin or to any extremity of 50 rem $(0.5 \mathrm{~Sv})$

Equivalent dose to the whole body may be used as the effective dose for external exposures. The TED during a year shall be determined by summing the effective dose from external exposures and the committed effective dose (CED) from intakes during the year and shall be used when demonstrating compliance with Table 2-1 dose limits. All occupational doses received during the current year except emergency exposures authorized according to 10 CFR 835.1302 shall be included. Occupational dose limits are summarized in Table 2-1.

2. General employees who have not received Radiological Worker I or II (RW-I or RW-II) training are not expected to exceed 100 mrem in a year.

3. Planned special exposures are beyond the scope of operations conducted by NNSA/NSO.

4. Guidelines for emergency exposures are provided in Appendix 2A. For compliance with 10 CFR 835.1302, in emergency exposure situations, the following must apply: 
a. The risk of injury to those individuals involved in rescue and recovery operations shall be minimized.

b. Operating management shall weigh actual and potential risks against the benefits to be gained.

c. No individual shall be required to perform rescue actions that might involve substantial personal risk.

d. Each individual authorized to perform emergency actions likely to result in occupational doses exceeding the values of the limits provided in $10 \mathrm{CFR}$ 835.202(a) shall be trained according to 10 CFR 835.901(b) and briefed beforehand on the known or anticipated hazards to which the individual will be subjected.

5. A general employee whose occupational dose has exceeded any of the limits specified in Table 2-1 or Appendix 2C, Table 2C-1, as a result of an authorized emergency exposure may be permitted to return to work in radiological areas during the current year, providing that all of the following conditions are met:

a. Approval is first obtained from the TO SSE and the NNSA/NSO Manager.

b. The individual receives counseling from radiological protection and medical personnel regarding the consequences of receiving additional occupational exposure during the year.

c. The affected employee agrees to return to radiological work.

Determinations of the effective dose shall be made using the radiation and tissue weighting factors provided in 10 CFR 835.2, "Definitions," under Radiation Weighting Factors.

Table 2-1 Summary of Occupational Dose Limits

\begin{tabular}{|c|c|c|}
\hline \multicolumn{2}{|r|}{ TYPE OF EXPOSURE } & ANNUAL LIMIT \\
\hline Radiological Worker & Whole Body (internal + external) & 5 rem \\
\hline Radiological Worker & Lens of Eye & $15 \mathrm{rem}$ \\
\hline Radiological Worker & $\begin{array}{l}\text { Extremity (hands and arms below the elbow; } \\
\text { feet and legs below the knees) }\end{array}$ & 50 rem \\
\hline Radiological Worker & $\begin{array}{c}\text { Any organ or tissue } \\
\text { (other than lens of eye) and skin }\end{array}$ & $50 \mathrm{rem}$ \\
\hline $\begin{array}{l}\text { Declared Pregnant } \\
\text { Worker }\end{array}$ & Embryo/Fetus & $\begin{array}{c}0.5 \text { rem } \\
\text { per gestation period }\end{array}$ \\
\hline Minors (under age 18) & $\begin{array}{c}\text { Whole Body (internal + external) } \\
\text { Lens of the eye } \\
\text { Extremities or skin }\end{array}$ & $\begin{array}{l}0.1 \text { rem } \\
1.5 \text { rem } \\
5 \text { rem }\end{array}$ \\
\hline Members of the Public & Whole Body (internal + external) & $0.1 \mathrm{rem}$ \\
\hline
\end{tabular}




\section{Table 2-1 Notes:}

1. Internal dose to the whole body shall be calculated as a CED. The CED is the resulting dose committed to the whole body from internally deposited radionuclides over a 50-year period after intake. See Appendix 2B for the weighting factors to be used in converting organ dose equivalent to committed effective dose for the whole body.

2. The annual limit of exposure to "any organ or tissue" is based on the committed dose to that organ or tissue resulting from internally deposited radionuclides over a 50-year period after intake plus any external effective dose to that organ during the year.

3. Doses from background, therapeutic and diagnostic medical radiation, and participation as a subject in medical research programs shall not be included in dose records or in the assessment of compliance with the occupational dose limits.

4. See Appendix 2A for guidance on emergency exposure limits.

5. See Appendix $2 \mathrm{C}$ for guidance on non-uniform exposure of the skin.

\section{Members of the Public Dose Limits}

The TED limits for members of the public exposed to radiation and/or radioactive material during access to a Controlled Area is 0.1 rem ( 0.001 sievert) in a year.

\section{Embryo/Fetus Dose Limits}

After a female worker voluntarily notifies her employer in writing that she is pregnant, she is considered a declared pregnant worker for the purposes of fetal/embryo dose protection. The declared pregnant worker may revoke this declaration in writing at any time.

1. For a declared pregnant worker who chooses to continue working as a radiological worker:

a. The equivalent dose limit for the embryo/fetus from conception to birth (entire gestation period) is 500 mrem.

b. Measures shall be taken to avoid substantial variation above the uniform exposure rate necessary to meet the 500 mrem limit for the gestation period. Efforts should be made to avoid exceeding $50 \mathrm{mrem}$ per month to the declared pregnant worker.

2. If the equivalent dose to the embryo/fetus is determined to have already exceeded 500 mrem when a worker notifies her employer of her pregnancy, the worker shall not be assigned to tasks where additional occupational radiation exposure is likely during the remainder of the gestation period. 
3. The employer should provide the option of a mutually agreeable assignment of work tasks, without loss of pay or promotional opportunity, such that further occupational radiation exposure during the remainder of the gestation period is unlikely.

\section{PART 2 CONTAMINATION CONTROL AND CONTROL LEVELS}

Control of radioactive contamination should be achieved through engineered controls and worker performance to contain contamination at the source, reducing existing areas of contamination, and promptly decontaminating areas that become contaminated.

\section{Contamination Control Levels}

1. A surface shall be considered contaminated if radioactivity is detected above the levels in Table 2-2. If an area cannot be decontaminated promptly, it shall be posted as specified in Article 235.

2. Any area in which contamination levels exceed Table 2-2 limits shall be controlled in a manner commensurate with the physical and chemical characteristics of the contaminant, the radionuclide(s) present, and the fixed and removable contamination levels.

3. Areas or items accessible to individuals where the measured total surface contamination levels exceed, but the removable surface contamination levels are less than, corresponding surface contamination values specified in Table 2-2, shall be controlled as follows when located outside of radiological areas:

a. The area or item shall be routinely monitored to ensure the removable surface contamination level remains below the removable surface contamination values specified in Table 2-2.

b. The area or item shall be conspicuously marked to warn individuals of the contaminated status.

c. Fixed contamination markings shall be kept legible and should include the standard radiation symbol, be clearly visible from all directions, and contrast with the colors of the surface.

d. Unrestricted access is not likely to result in a dose to any person greater than 100 mrem in a year.

4. Areas or items with only fixed contamination in excess of Table 2-2 are exempt from the general posting requirements of Article 231 and entry and exit requirements of Chapter 3 . 
Table 2-2 Surface Contamination Values in $\mathrm{dpm} / 100 \mathrm{~cm}^{2}$

\begin{tabular}{|c|c|c|c|}
\hline $\begin{array}{l}\text { NUCLIDE } \\
\text { (Note 1) }\end{array}$ & $\begin{array}{l}\text { REMOVABLE } \\
\text { (Notes } 2 \text { \& 4) }\end{array}$ & $\begin{array}{l}\text { TOTAL (FIXED } \\
+ \text { REMOVABLE) } \\
\text { (Notes } 2 \text { \& 3) }\end{array}$ & $\begin{array}{l}\text { MAXIMUM } \\
\text { ALLOWABLE } \\
\text { (FIXED + } \\
\text { REMOVABLE) }\end{array}$ \\
\hline $\begin{array}{l}\text { Transuranics, }{ }^{125} \mathrm{I},{ }^{129} \mathrm{I},{ }^{226} \mathrm{Ra},{ }^{227} \mathrm{Ac}, \\
{ }^{228} \mathrm{Ra},{ }^{228} \mathrm{Th},{ }^{230} \mathrm{Th},{ }^{231} \mathrm{~Pa},\end{array}$ & 20 & 500 & 1,500 \\
\hline $\begin{array}{l}\text { Th-nat, }{ }^{90} \mathrm{Sr},{ }^{126} \mathrm{I},{ }^{131} \mathrm{I},{ }^{133} \mathrm{I},{ }^{223} \mathrm{Ra},{ }^{224} \mathrm{Ra}, \\
{ }^{232} \mathrm{U},{ }^{232} \mathrm{Th},\end{array}$ & 200 & 1,000 & 3,000 \\
\hline $\begin{array}{l}\text { U-natural, }{ }^{235} \mathrm{U},{ }^{238} \mathrm{U} \text { and associated } \\
\text { decay products }\end{array}$ & $1,000 \alpha$ & $5,000 \alpha$ & $15,000 \alpha$ \\
\hline $\begin{array}{l}\beta+\gamma \text { emitters (nuclides with decay } \\
\text { modes other than } \alpha \text {-emission or } \\
\text { spontaneous fission) except }{ }^{90} \mathrm{Sr} \text { and } \\
\text { others noted above (Note 5). }\end{array}$ & $1,000 \beta+\gamma$ & $5,000 \beta+\gamma$ & $15,000 \beta+\gamma$ \\
\hline Tritium and tritiated compounds (Note 6). & 10,000 & N/A & N/A \\
\hline
\end{tabular}

Table 2-2 Notes:

1. The values in this table, with the exception noted in Note 6, apply to radioactive contamination deposited on, but not incorporated into the interior or matrix of, the contaminated item. Where surface contamination by both alpha- and beta/gamma-emitting nuclides exists, the limits established for alpha- and beta/gamma-emitting nuclides apply independently.

2. As used in this table, disintegrations per minute (dpm) means the rate of emission by radioactive material as determined by correcting the counts per minute observed by an appropriate detector for background, efficiency, and geometric factors associated with the instrumentation.

3. The levels may be averaged over 1 square meter $\left(\mathrm{m}^{2}\right)$ provided the maximum surface activity in any area of 100 square centimeter $\left(\mathrm{cm}^{2}\right)$ is less than three times the value specified in Column 3; these values are included in Column 4. For purposes of averaging, any square meter of surface shall be considered to be above the surface contamination value if:

a. From measurements of a representative number of sections it is determined that the average contamination level exceeds the applicable value; or

b. It is determined that the sum of the activity of all isolated spots or particles in any $100-\mathrm{cm}^{2}$ area exceeds three times the applicable value from Column 3. 
4. The amount of removable radioactive material per $100 \mathrm{~cm}^{2}$ of surface area should be determined by swiping the area with dry filter or soft absorbent paper, applying moderate pressure, and then assessing the amount of radioactive material on the swipe with an appropriate instrument of known efficiency.

Note: The use of dry material may not be appropriate for tritium.

When removable contamination on objects of surface area less than $100 \mathrm{~cm}^{2}$ is determined, the activity per unit area shall be based on the actual area and the entire surface shall be swiped. It is not necessary to use swiping techniques to measure removable contamination levels if direct scan surveys indicate that the total surface contamination levels are within the limits for removable contamination.

5. This category of radionuclides includes mixed fission products, including the $\mathrm{Sr}-90$ which is present in them. It does not apply to Sr-90 that has been separated from the other fission products or mixtures where the Sr-90 has been enriched.

6. Tritium contamination may diffuse into the volume or matrix of materials. Evaluation of surface contamination shall consider the extent to which such contamination may migrate to the surface in order to ensure the surface contamination value provided in this table is not exceeded. Once this contamination migrates to the surface, it may be removable, not fixed; therefore, a "Total" value does not apply.

\section{Airborne Radioactivity Control Levels}

1. The data presented in 10 CFR 835 Appendix A, "Derived Air Concentrations (DAC) for Controlling Radiation Exposure to Workers at DOE Facilities," are to be used for controlling individual internal doses and 10 CFR 835 Appendix C, "Derived Air Concentrations (DAC) for Workers From External Exposure During Immersion in a Cloud of Airborne Radioactive Material," are to be used for controlling individual external doses according to 10 CFR 835.209, identifying the need for air monitoring according to 10 CFR 835.403, and identifying and controlling Airborne Radioactivity Areas according to 10 CFR 835.603(d).

2. Airborne Radioactivity Area means any area, accessible to individuals, where either:

a. The concentration of airborne radioactivity, above natural background, exceeds or is likely to exceed the DAC values listed in 10 CFR 835 Appendix A or Appendix C.

b. An individual present in the area without respiratory protection could receive an intake exceeding 12 DAC-hours in a week. 
3. For known mixtures of radionuclides, the sum of the ratio of the observed concentration of a particular radionuclide and its corresponding DAC, for all radionuclides in the mixture, must not exceed 1.0. For unknown radionuclides, the most restrictive DAC (lowest value) for those isotopes not known to be absent shall be used. For any single radionuclide not listed in Appendix A with decay mode other than alpha emission or spontaneous fission and with radioactive half-life greater than two hours, the DAC value shall be $4 \mathrm{E}-11$ $\mu \mathrm{Ci} / \mathrm{mL}(1 \mathrm{~Bq} / \mathrm{m} 3)$. For any single radionuclide not listed in Appendix $A$ that decays by alpha emission or spontaneous fission, the DAC value shall be $2 \mathrm{E}-13$ $\mu \mathrm{Ci} / \mathrm{mL}$ (8 E-03 Bq/m3).

\section{PART 3 POSTING}

\section{Posting Requirements}

1. Radiological postings shall be used to alert personnel to the presence of radiation and radioactive materials and to aid them in minimizing exposures and preventing the spread of contamination.

2. Each access point to a radiological area shall be posted according to Tables 2-3 and 2-4. Signs shall contain the standard radiation symbol ("trefoil") colored magenta or black on a yellow background. Lettering shall be either magenta or black.

3. Signs shall be conspicuously posted, clearly worded, and may include radiological control instructions, where appropriate. Radiological postings should be displayed only to signify actual or potential radiological conditions. Signs used for training should be clearly marked "For Training Purposes Only."

4. Posted areas should be as small as practicable. Signs should be attached at approximately 100 -foot intervals in accessible areas and at access points.

5. Postings should be maintained in a legible condition and updated based upon the results of the most recent surveys.

6. If more than one type of radiological area (such as contamination and high radiation) exists in the same area, each condition should be identified.

7. Rope, tape, chain, and similar barriers used to designate the boundaries of posted areas should be yellow or yellow and magenta in color. Existing barbed wire, chain link, yellow rope, or snow fencing is acceptable at NNSA/NSO facilities. These barriers shall be set up such that they do not impede the intended use of emergency exits or evacuation routes.

8. Posting of doors or access gates should be such that the postings remain visible when the doors and gates are open or closed. 
9. A radiological posting that signifies the presence of an intermittent radiological condition should include a statement specifying when the radiation is present, such as "CAUTION, RADIATION AREA WHEN FLASHING LIGHT IS ON."

10. The posting and labeling requirements in this manual may be modified to reflect the special considerations of DOE activities conducted at private residences or businesses. Such modifications shall provide the same level of protection to individuals as the existing provisions in this manual.

11. Exceptions to posting requirements:

a. $\quad$ Areas may be excepted from the posting requirements of 10 CFR 835.603 for periods of less than 8 continuous hours when placed under continuous observation and control of an individual knowledgeable of, and empowered to implement, required access- and exposure-control measures.

b. Areas may be excepted from the Radioactive Material Area (RMA) posting requirements of 10 CFR $835.603(\mathrm{~g})$ when:

(1) Posted according to 10 CFR 835.603(a) through (f); or

(2) Each item or container of radioactive material is labeled according to 10 CFR 835.605 such that individuals entering the area are made aware of the hazard; or

(3) The radioactive material of concern consists solely of structures or installed components that have been activated (i.e., such as being exposed to neutron radiation or particles produced in an accelerator).

c. Areas containing only packages received from radioactive material transportation labeled and in non-degraded condition need not be posted according to 10 CFR 835.603 until the packages are monitored according to 10 CFR 835.405.

\section{Posting Controlled Areas}

1. Each access point to a Controlled Area shall be posted. When any other radiological warning signs are present, the Controlled Area sign is not required. Individuals who enter only the Controlled Area without entering radiological areas or RMAs are not likely to receive a TED of more than 0.1 rem ( 0.001 sievert) in a year. 
2. As a minimum, the Controlled Area posting shall contain the following wording:

CONTROLLED AREA
THIS AREA IS CONTROLLED FOR THE PURPOSE OF LIMITING
ACCESS TO RADIATION OR RADIOACTIVITY.
GENERAL EMPLOYEE RADIOLOGICAL TRAINING (GERT)
IS REQUIRED FOR ACCESS

\section{Posting Radiological Buffer Areas}

Radiological buffer areas are intended to provide secondary boundaries within the controlled area to minimize the spread of contamination and to limit doses to general employees who have not been trained as radiological workers.

1. A radiological buffer area may be established for contamination control adjacent to any entrance to or exit from a contamination, high contamination, or airborne radioactivity area. The size of the radiological buffer area may be commensurate with the potential for the spread of contamination.

2. A radiological buffer area may be established for exposure control adjacent to radiation, high radiation, and very high radiation areas. The boundary for the radiological buffer area should be established to limit radiation doses to general employees to less than 100 millirem per year.

3. A radiological buffer area is not required for:
a. High contamination or airborne radioactivity areas that are completely within contamination areas.
b. Inactive contamination, high contamination, or airborne radioactivity areas (i.e., area to which entry has been prohibited by posting or barricades).
c. Exposure control, if other posted boundaries or controls provide equivalent employee protection.
d. Exposure control, if general employees who are not trained as radiological workers are restricted from unescorted entry to controlled areas.

4. The need for radiological buffer areas around RMAs, soil contamination areas, and Underground Radioactive Material Areas (URMAs) should be evaluated based upon the potential for exposure of unmonitored individuals and the spread of contamination.

5. Posting of radiological buffer areas may be in accordance with Article 231 and contain the wording "CAUTION, RADIOLOGICAL BUFFER AREA." 


\section{Posting of Radiation Areas, High Radiation Areas, and Very High Radiation Areas}

1. Areas shall be posted to alert personnel to the presence of external radiation according to Table 2-3 and Article 231.

2. Dose rate measurements used to determine Radiation Areas and High Radiation Areas shall be made at a distance of $30 \mathrm{~cm}$ from the radiation source or from any surface through which the radiation penetrates. For Very High Radiation Areas, the measurement or calculation should be made at a distance of $1 \mathrm{~m}$.

Table 2-3 Criteria for Posting Radiation Areas

\begin{tabular}{|c|c|c|}
\hline AREA & DOSE RATE CRITERIA & POSTING \\
\hline Radiation Area & $>0.005 \mathrm{rem}$ in one hour at $30 \mathrm{~cm}$ & "CAUTION, RADIATION AREA" \\
\hline High Radiation Area & $>0.1$ rem in one hour at $30 \mathrm{~cm}$ & $\begin{array}{c}\text { "CAUTION, HIGH } \\
\text { RADIATION AREA" } \\
\text { or } \\
\text { "DANGER, HIGH RADIATION } \\
\text { AREA" }\end{array}$ \\
\hline $\begin{array}{l}\text { Very High Radiation } \\
\text { Area }\end{array}$ & $>500 \mathrm{rad}$ in one hour at $1 \mathrm{~m}$ & $\begin{array}{l}\text { "GRAVE DANGER, VERY HIGH } \\
\text { RADIATION AREA" }\end{array}$ \\
\hline
\end{tabular}

\section{Posting Contamination, High Contamination, and Airborne Radioactivity Areas}

1. Areas shall be posted to alert personnel to contamination according to Table 2-4 and Article 231.

2. The physical and chemical characteristics of, and the radionuclides present in, the contamination will be considered in determining the limiting conditions and/or access controls to be specified on the RWP.

3. DAC values for use with Table 2-4 as found in 10 CFR 835 shall be used in the control of occupational exposure to airborne radioactive material. 
Table 2-4 Criteria for Posting Contamination, High Contamination, and Airborne Radioactivity Areas

\begin{tabular}{|c|c|c|}
\hline AREA & CRITERIA & POSTING \\
\hline Contamination & $\begin{array}{l}\text { Removable contamination levels }>1 \text { time } \\
\text { but } \leq 100 \text { times Table } 2-2 \text { values. }\end{array}$ & $\begin{array}{c}\text { "CAUTION, } \\
\text { CONTAMINATION AREA" }\end{array}$ \\
\hline High Contamination & $\begin{array}{l}\text { Removable contamination levels } \\
>100 \text { times Table } 2-2 \text { values. }\end{array}$ & $\begin{array}{c}\text { "CAUTION, HIGH } \\
\text { CONTAMINATION AREA" } \\
\text { or } \\
\text { "DANGER, HIGH } \\
\text { CONTAMINATION AREA" }\end{array}$ \\
\hline Airborne Radioactivity & $\begin{array}{l}\text { Concentrations }(\mu \mathrm{Ci} / \mathrm{ml})>\text { any } \mathrm{DAC} \text { value } \\
\text { or potential for intakes exceeding } 12 \mathrm{DAC} \\
\text { hours/week without respiratory protection. }\end{array}$ & $\begin{array}{c}\text { "CAUTION, AIRBORNE } \\
\text { RADIOACTIVITY AREA" } \\
\text { or } \\
\text { "DANGER, AIRBORNE } \\
\text { RADIOACTIVITY AREA" }\end{array}$ \\
\hline
\end{tabular}

\section{Posting Radioactive Material Areas}

1. Accessible areas where items or containers of radioactive material in quantities exceeding the values provided in Appendix E of 10 CFR 835 are used, handled, or stored shall be posted "CAUTION, RADIOACTIVE MATERIAL." The posting shall meet the requirements in Article 231.

2. RMAs shall be located within Controlled Areas.

3. RMAs need not be posted when:

a. The area is posted as a radiological area according to Article 234 or 235; or

b. Each item or container of radioactive material in the area is clearly labeled to warn individuals of the hazards; or

c. The radioactive material of concern consists solely of structures or installed components that have been activated (such as by exposure to neutron radiation or particles produced in an accelerator); or

d. The area contains only packages of radioactive material received from transportation while awaiting survey according to Articles 552 and 554; or

e. For periods of 8 continuous hours or less, the area is under the direct observation and control of an individual knowledgeable of and empowered to implement required access control measures.

4. The definition of radioactive material and the provisions for labeling radioactive material are provided in Chapter 4. 


\section{Posting Underground Radioactive Material Areas}

1. URMAs should be posted "CAUTION, UNDERGROUND RADIOACTIVE MATERIAL." Posting may include instructions or special warnings to workers such as "Consult Radiological Control Organization before Digging" or "Subsurface Contamination Exists." The posting shall meet the applicable requirements of Article 231.

2. URMAs are exempt from the entry and exit requirements of Chapter 3 when access is not likely to result in individual doses greater than 100 mrem in a year. Article 333 provides entry provisions for instances in which access is likely to result in individual doses greater than $100 \mathrm{mrem}$ in a year.

\section{Posting Entombed Radioactive Material Areas}

1. Entombed RMAs may be established to indicate the presence of items or enclosures containing radioactive material that are fully enveloped in place in monolithic grout or concrete making the item or area immovable and the radioactive material inaccessible. Radiation exposure and removable radioactive contamination attributable to the entombed radioactive material are prevented by the entombment.

2. Entombed RMAs should be posted "CAUTION ENTOMBED RADIOACTIVE MATERIAL." The posting shall meet the applicable requirements of Article 231. 


\section{Appendix 2A}

\section{GUIDELINES FOR CONTROL OF EMERGENCY EXPOSURES}

The dose guidelines for personnel performing these operations are listed below:

Table 2A-1 Guidelines for Control of Emergency Exposures

\begin{tabular}{|c|c|c|}
\hline $\begin{array}{l}\text { DOSE } \\
\text { GUIDELINES } \\
\text { (TEDE) }\end{array}$ & ACTIVITY PERFORMED & CONDITIONS \\
\hline $5 \mathrm{rem}$ & All & Dose should be kept ALARA \\
\hline $10 \mathrm{rem}$ & Protecting major property & $\begin{array}{l}\text { Only on a voluntary basis where lower } \\
\text { dose limit not practical }\end{array}$ \\
\hline 25 rem & $\begin{array}{l}\text { Lifesaving or protection of large } \\
\text { populations }\end{array}$ & $\begin{array}{l}\text { Only on a voluntary basis where lower } \\
\text { dose limit not practical }\end{array}$ \\
\hline$>25$ rem & $\begin{array}{l}\text { Lifesaving or protection of large } \\
\text { populations }\end{array}$ & $\begin{array}{l}\text { Only on a voluntary basis by personnel } \\
\text { fully aware of the risks involved }\end{array}$ \\
\hline
\end{tabular}

\section{Table 2A-1 Notes:}

1. The equivalent dose to the lens of the eye guidelines should be 3 times the listed values.

2. The equivalent dose to the skin or to an extremity guidelines is 10 times the listed values.

3. When the condition under which a dose was received in excess of the limits specified in 10 CFR 835.202 has been eliminated, operating management shall notify the NNSA/NSO Manager. Operations after a dose was received in excess of the limits specified in 10 CFR 835.202 may be resumed only with the approval of NNSA/NSO. 
Appendix 2B

TISSUE WEIGHTING FACTORS FOR VARIOUS ORGANS AND TISSUES

Table 2B-1 Tissue Weighting Factors for Various Organs and Tissues

\begin{tabular}{|c|c|}
\hline ORGANS OR TISSUES, T & $\begin{array}{c}\text { TISSUE } \\
\text { WEIGHTING } \\
\text { FACTOR, } \mathbf{w}_{\mathbf{T}}\end{array}$ \\
\hline Gonads & 0.20 \\
\hline Red bone marrow ..... & 0.12 \\
\hline Colon ............................ & 0.12 \\
\hline 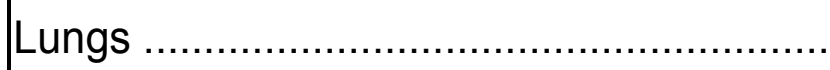 & 0.12 \\
\hline Stomach & 0.12 \\
\hline Bladder ............. & 0.05 \\
\hline Breast .................. & 0.05 \\
\hline Liver ................... & 0.05 \\
\hline Esophagus .................... & 0.05 \\
\hline 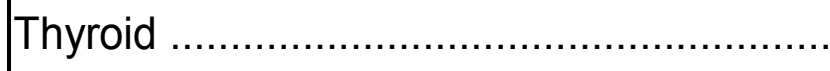 & 0.05 \\
\hline Skin .................. & 0.01 \\
\hline Bone surfaces. & 0.01 \\
\hline Remainder ${ }^{1}$ & 0.05 \\
\hline Whole body ${ }^{2}$ & 1.00 \\
\hline
\end{tabular}

Table 2B-1 Notes:

1. "Remainder" means the following additional tissues and organs and their masses, in grams, following parenthetically: adrenals (14), brain $(1,400)$, extrathoracic airways (15), small intestine (640), kidneys (310), muscle $(28,000)$, pancreas (100), spleen (180), thymus (20), and uterus (80). The equivalent dose to the remainder tissues $\left(\mathrm{H}_{\text {remainder }}\right)$ is normally calculated as the mass-weighted mean dose to the preceding ten organs and tissues. In those cases in which the most highly irradiated remainder tissue or organ receives the highest equivalent dose of all the organs, a weighting factor of 0.025 (half of remainder) is applied to that tissue or organ, and 0.025 (half of remainder) to the mass-weighted equivalent dose in the rest of the remainder tissues and organs to give the remainder equivalent dose.

2. For the case of uniform external irradiation of the whole body, a tissue weighting factor $\left(\mathrm{w}_{\mathrm{T}}\right)$ equal to 1 may be used to determine the effective dose. 


\section{Appendix 2C}

\section{NON-UNIFORM EXPOSURE OF THE SKIN}

Non-uniform exposures of the skin from $\mathrm{x}$-rays, beta radiation, and radioactive materials on the skin shall be assessed and recorded as specified in the following table.

Table 2C-1 Non-Uniform Exposure of the Skin

\begin{tabular}{|c|c|}
\hline $\begin{array}{l}\text { AREA OF SKIN } \\
\text { IRRADIATED }\end{array}$ & $\begin{array}{c}\text { METHOD OF AVERAGING, ADDING TO OTHER DOSES RECEIVED, } \\
\text { AND RECORDING NONUNIFORM SKIN DOSE }\end{array}$ \\
\hline$\geq 100 \mathrm{~cm}^{2}$ & $\begin{array}{l}\text { Averaged over the } 100 \mathrm{~cm}^{2} \text { of skin receiving the maximum dose } \\
\text { Added to any uniform equivalent dose also received by the skin } \\
\text { Recorded as the annual equivalent dose to the skin or to an extremity }(\mathrm{H})\end{array}$ \\
\hline $\begin{array}{c}\geq 10 \mathrm{~cm}^{2} \\
\quad \text { and } \\
<100 \mathrm{~cm}^{2}\end{array}$ & $\begin{array}{l}\text { Averaged over the } 1 \mathrm{~cm}^{2} \text { of skin receiving the maximum dose }(D), \text { reduced } \\
\text { by the fraction }(f) \text {, which is the irradiated area in } \mathrm{cm}^{2} \text { divided by } 100 \mathrm{~cm}^{2} \\
\text { (i.e., } H=f D) . \text { "In no case shall a value of }(f) \text { less than } 0.1 \text { be used." } \\
{[10 \text { CFR } 835.205(b)(2)]} \\
\text { Added to any uniform equivalent dose also received by the skin } \\
\text { Recorded as the annual equivalent dose to the skin or to an extremity }(H)\end{array}$ \\
\hline$<10 \mathrm{~cm}^{2}$ & $\begin{array}{l}\text { Averaged over the } 1 \mathrm{~cm}^{2} \text { of skin receiving the maximum dose } \\
\text { Not added to any other equivalent dose to the extremity or skin for the year } \\
\text { Recorded in the individual's radiation dose record as a special entry }\end{array}$ \\
\hline
\end{tabular}


THIS PAGE INTENTIONALLY LEFT BLANK 


\section{TABLE OF CONTENTS}

$\underline{\text { Article }}$

Page

PART 1 PLANNING RADIOLOGICAL WORK ........................................................ 3-1

311 Requirements ................................................................................

312 Planning for Maintenance, Operations, and Modifications ............... 3-1

314 Temporary Shielding ...........................................................................3

315 Technical Work Documents .............................................................3

316 Minimization of Internal Exposure .................................................. 3-4

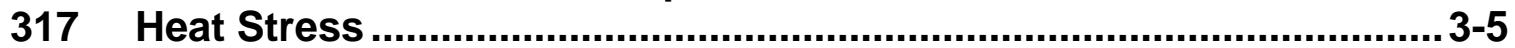

318 Environmental Conditions ...............................................................3-6

319 Other Workplace Hazards …............................................................. 3-6

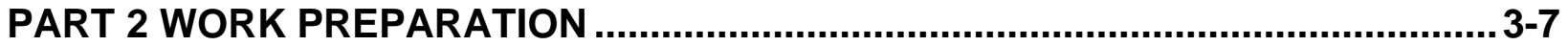

321 Radiological Work Permits ..........................................................

322 Using Radiological Work Permits ................................................ 3-7

323 Radiological Work Permit Preparation............................................. 3-9

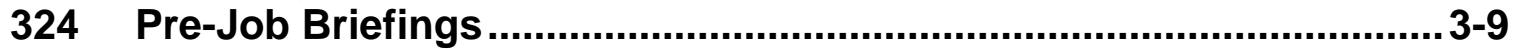

325 Personal Protective Equipment and Protective Clothing .................3-10

PART 3 ENTRY AND EXIT REQUIREMENTS ................................................... 3-10

331 Controlled Areas ...........................................................................

333 Radioactive Material Areas and Underground Radioactive Material Areas..........................................................................................3-11

334 Radiation, High Radiation, and Very High Radiation Areas ............ 3-11

335 Contamination, High Contamination, and Airborne Radioactivity Areas.........................................................................................12

336 Entry Requirements for Members of the Public ..............................3-13

337 Controlling the Spread of Contamination.......................................3-13

338 Monitoring for Personnel Contamination .......................................3-14

PART 4 RADIOLOGICAL WORK CONTROLS ................................................... 3-14

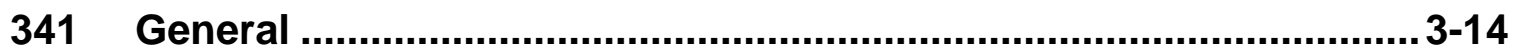

342 Work Conduct and Practices ...................................................... 3-14

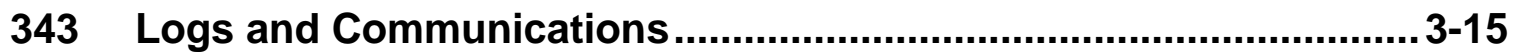

344 Review of Work in Progress .................................................... 3-15

345 Radiological Stop Work Authority .............................................. 3-16

346 Response to Abnormal Situations ............................................... 3-16

347 Controls for Bench-Top Work, Laboratory Fume Hoods, Sample Stations, and Glove Boxes. 


\section{TABLE OF CONTENTS (continued)}

$\underline{\text { Article }}$

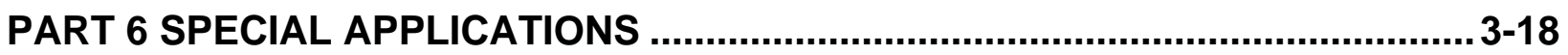

361 Plutonium Operations ….............................................................

362 Uranium Operations ................................................................. 3-18

363 Tritium Operations...................................................................... 3-18

364 Accelerator Operations ............................................................... 3-18

365 Radiographic Sealed Sources and Radiation-Generating Devices 3-18

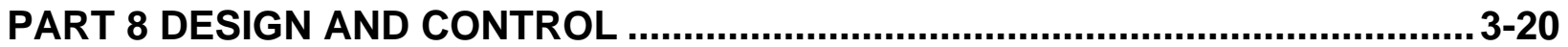

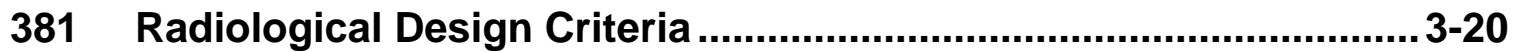

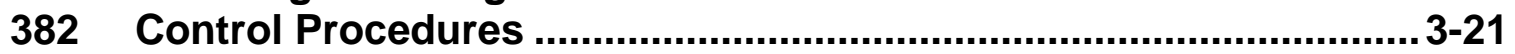

Appendix 3A PHYSICAL ACCESS CONTROLS FOR HIGH AND VERY HIGH

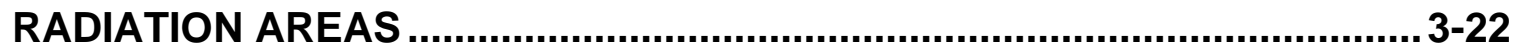

Appendix 3B CONTAMINATION CONTROL PRACTICES.....................................3-23

Appendix 3C GUIDELINES FOR PERSONNEL CONTAMINATION MONITORING WITH HAND-HELD SURVEY INSTRUMENTS............................................3-28 


\section{PART 1 PLANNING RADIOLOGICAL WORK}

\section{Requirements}

Technical requirements for the conduct of work, including construction, modifications, operations, maintenance, and decommissioning shall incorporate radiological criteria to ensure safety and maintain radiation exposures ALARA. The primary methods used to maintain exposures ALARA shall be facility and equipment design features. These features shall be augmented by administrative and procedural requirements. The design and planning processes shall incorporate radiological considerations in the early planning stages. To ensure adequate protection of the work force, planning for radiological work should also include consideration of all other workplace hazards (e.g., industrial hygiene and safety, fire safety, electrical safety), consistent with the principles of Integrated Safety Management.

1. Measures shall be taken to maintain radiation exposure in controlled areas ALARA through engineered and administrative controls.

2. The primary methods used shall be engineered controls (e.g., confinement, ventilation, remote handling, and shielding).

3. Administrative controls shall be employed only as supplemental methods to control radiation exposure.

4. For specific activities where use of engineered controls is demonstrated to be impractical, administrative controls shall be used to maintain radiation exposures ALARA.

5. During routine operations, the combination of engineered and administrative controls shall provide that the anticipated occupational dose to general employees shall not exceed the limits established in Table 2-1 and that doses are maintained ALARA.

\section{Planning for Maintenance, Operations, and Modifications}

1. Work plans and procedures shall be reviewed to identify and incorporate radiological requirements, such as engineered controls and dose and contamination reduction considerations. Performing this review is the responsibility of line management, with support and concurrence from the RCO.

2. The radiological hazard assessment and control process should be integrated with the processes used to assess and control other workplace hazards.

3. Ground-disturbing/soil-penetrating activities in posted NTS-controlled areas shall be cleared through the TO RCO or RSPC RCO before beginning work to ensure radiological safety. 
4. For routine tasks such as surveillance, tours, and minor nonradiological maintenance, performance of the above review and documentation of identified radiological protection requirements should be conducted as part of the RWP process (see Article 321) or other work authorization process that may be appropriate.

5. NNSA/NSO specific trigger levels requiring a formal, documented, ALARA review are:
a. Estimated individual or whole-body dose of greater than 100 mrem or estimated collective whole-body dose of greater than $500 \mathrm{mrem}$.
b. Predicted airborne radioactivity concentrations in excess of 10 times applicable DAC value.
c. Removable contamination on accessible surfaces greater than 100 times the values in Table 2-2.
d. Entry into areas where dose rates exceed 1 rem/hour.

6. This ALARA review should consider the following:
a. Including radiological control hold points in the technical work documents.
b. Eliminating or reducing radioactivity through decontamination.
c. Using work processes and special tooling to reduce the time in the work area.
d. Using engineered controls to minimize the spread of contamination and the generation of airborne radioactivity.
e. Specifying special radiological training or monitoring requirements.
f. Using mock-ups for high exposure or complex tasks.
g. Using engineered controls, design, and temporary shielding to reduce radiation levels.
h. Performing a walk-down or dry run of the activity using applicable procedures.
i. $\quad$ Staging and preparing necessary materials and special tools.
j. Maximizing prefabrication and shop work.
k. Reviewing abnormal and emergency procedures and plans.
I. Identifying points where signatures and second party or independent verifications are required.
m. Establishing success or completion criteria, with contingency plans to anticipate difficulties.
n. Developing a pre-job estimate of collective dose to be incurred for the job.
o. Making provisions for waste minimization and disposal. 
7. Radiological requirements identified as part of the above radiological review should be documented in the job plans, procedures, or work packages.

8. Radiological work anticipated to exceed individual or collective dose criteria established in this manual should be reviewed and approved by the appropriate ALARA Committee.

a. NNSA/NSO operations involving single organizations require review and approval by their internal ALARA Committee (or its equivalent).

b. NNSA/NSO operations involving multiple organizations require review and approval by the SWAC.

9. Optimization methods shall be used to ensure that occupational exposure is maintained ALARA in developing and justifying facility design and physical controls for new facilities or modifications of existing facilities.

\section{Temporary Shielding}

1. The installation, use, and removal of temporary shielding should be controlled by procedure.

2. The effects of the additional weight of temporary shielding on systems and components should be evaluated and established to be within the design basis prior to installation.

3. Installed temporary shielding should be periodically inspected and surveyed to verify effectiveness and integrity. Installed temporary shielding should be periodically evaluated to assess the need for its removal or replacement with permanent shielding.

4. Radiation surveys should be performed during the alteration or removal of installed temporary shielding.

5. Installed temporary shielding should be visibly marked or labeled with the following or equivalent wording: "Temporary Shielding - Do Not Remove Without Permission from Radiological Control."

6. Site procedures may identify specific shielding applications, such as the shielding of low activity sources or samples that fall outside the recommendations of this Article.

\section{Technical Work Documents}

1. Technical work documents used to control radiological work activities should be reviewed and approved by the radiological control organization. 
2. Radiological control hold points should be incorporated into technical work documents for steps that require action by the RCO to assess existing radiological conditions or prevent significant adverse radiological consequences during subsequent steps. The following activities and potential conditions should be considered for inclusion in the requirements for radiological control hold points:
a. RCO action needed to assess changing radiological conditions and ensure implementation of required controls
b. Potential for radiation doses in excess of the applicable site-specific administrative control level
c. Potential for elevated airborne radioactivity levels (e.g., levels exceeding 10 times the DAC values provided in Appendices A and C of 10 CFR 835)
d. Potential for elevated removable surface contamination levels on accessible surfaces (e.g., levels exceeding 100 times the Table 2-2 values)
e. Potential for unplanned or uncontrolled release of radioactive material to the environment

3. The radiological control hold point should include the criteria that must be met or action that must be taken to satisfy the hold point prior to continuing with subsequent steps in the planned activity.

\section{Minimization of Internal Exposure}

1. Engineered controls, including containment of radioactive material at the source, shall be the primary method of minimizing airborne radioactivity and internal exposure to workers.

2. Administrative controls, including access restrictions and the use of specific work practices designed to minimize airborne radioactivity, shall be used as the secondary method to minimize worker internal exposure.

3. When engineered and administrative controls have been applied and the potential for airborne radioactivity still exists, respiratory protection should be considered to limit internal exposures. The use of respiratory protection should be considered under the following conditions:
a. During entry into posted Airborne Radioactivity Areas.
b. During breach of contaminated systems or components.
c. While working in areas or on equipment with removable contamination levels greater than 100 times the values in Table 2-2.
d. During work on contaminated or activated surfaces with the potential to generate airborne radioactivity.


4. The selection of respiratory protection equipment should include the consideration of worker safety, comfort, and efficiency. Using positive-pressure respiratory protection devices is recommended to alleviate fatigue and increase comfort.

5. In specific situations, the use of respiratory protection may be inadvisable due to physical limitations or the potential for significantly increased external exposure. In such situations, a formal ALARA review should be conducted according to Article 312 to ensure measures are implemented to assess available options, monitor and reduce worker exposure, and provide for follow-up monitoring as required. Written authorization should be obtained from the TO line manager and RadCon Manager before incurring the internal exposure. Specific justification of the need to accept the exposure, including a description of measures taken to mitigate the airborne radioactivity, should be documented as part of the authorization process.

6. The following controls are applicable for authorized activities:

a. Establish stay time controls for the entry to limit intake.

b. Use continuous air monitors (CAMs) or air samplers with an expedited analysis and assessment of the results to evaluate workplace airborne radioactivity levels.

7. When notified that an individual with an open wound wishes to enter an area where contact with radioactive contamination is possible, a representative of the RCO should examine the wound and require appropriate measures to prevent the entry of radioactive contamination. These measures may range from requiring an appropriate bandage or other covering to prohibiting access to affected areas until the wound has healed. If other (non-radiological) hazards are present in the area to be entered, the individual should be directed to contact the applicable safety personnel.

\section{Heat Stress}

The use of PPE can itself create significant worker hazards, such as heat stress, physical and psychological stress, and impaired vision, mobility, and communication. For any given situation, equipment and clothing should be selected that provide an adequate level of protection. However, overprotection, as well as under-protection, can be hazardous and should be avoided where possible. Heat stress has occurred at ambient temperatures less than $70^{\circ} \mathrm{F}$ when multiple sets of anti-contamination clothing or plastic suits were in use or strenuous work was required.

1. The planning stages for work in hot environments should address heat stress controls.

2. Job supervisors should inform their personnel of heat stress precautions prior to work on job assignments in hot environments. 
3. Precautions that should be considered during work that includes a high probability of heat stress include the following:
a. Engineered controls to moderate the work area environment
b. Appropriate work time limits
c. Use of protective clothing made of materials that wick perspiration away from the body
d. Use of body cooling devices
e. Provision of beverages at or near the work site, using appropriate contamination controls
f. Relaxation of protective clothing requirements

\section{Environmental Conditions}

Inclement weather or other environmental conditions may disrupt radiological controls. If that occurs, the following actions should be considered:

1. Use of covers, windscreens, and runoff collection basins to prevent the spread of radioactive material

2. Provision for worksite personnel to assemble and be monitored before release or re-establishing work

3. Evaluation of work areas to determine if a need exists for modified work controls or decontamination

4. Issue of winter-weight modesty garments to shield personnel from cold stress while wearing PC outdoors in inclement weather

\section{Other Workplace Hazards}

Radiological controls should be administered in a way to ensure that protection from other workplace hazards can also be achieved. Other workplace hazards may include, but are not limited to, the following:

1. General construction hazards

2. Confined spaces

3. Flammable and combustible materials

4. Hazardous materials

5. Toxic substances

6. Electrical systems

7. Heat stress and cold stress
8. Biological hazards

9. Noise and vibration

10. Machinery and machine guarding

11. Excavations and trenches

12. High explosives and blasting

13. Hand and portable powered tools

14. Walking and working surfaces

15. Means of egress 


\section{PART 2 WORK PREPARATION}

\section{Radiological Work Permits}

The RWP is used to establish radiological controls for intended work activities. The RWP informs workers of area radiological conditions and entry requirements and provides a mechanism to relate worker exposure to specific work activities.

Add-on sheets for additional authorization signatures and/or worker acknowledgment signatures, as well as appendices containing information not addressed in the RWP, may be attached as necessary. The RWP includes the following information:

1. Work description

2. Work area radiological conditions

3. Dosimetry requirements

4. Pre-job briefing requirements, as applicable

5. Training requirements for entry

6. $\quad P C$ and respiratory protection requirements

7. Radiological control coverage and stay time controls, as applicable

8. Limiting radiological conditions that may void the RWP

9. Special dose- or contamination-reduction considerations

10. Special personnel monitoring considerations

11. Technical work document number or procedure, as applicable

12. Unique identifying number

13. Date of issue and expiration

14. Authorizing signatures and concurrence signatures of TO RadCon Managers (or their designated alternates) of all organizations involved in the work project covered by the RWP

\section{Using Radiological Work Permits}

1. RWPs or an alternative, formal mechanism as described in Article 322.9 shall be used to control the following activities:
a. Entering Radiation Areas
b. Entering Contamination Areas
c. Handling materials with removable contamination that exceed the values of Table 2-2
d. Work that involves digging in URMAs 
2. Job-specific RWPs shall be used to control non-routine operations or work in areas with changing radiological conditions. The job-specific RWP shall remain in effect only for the duration of the job.

3. Standing RWPs may be used to control routine or repetitive activities. They may also be used for training exercise scenarios that are a standard part of DOE sanctioned or Federal Emergency Management Agency sanctioned radiological, hazardous materials, and emergency response courses, if TO RadCon Manager oversight and procedural documentation are in place. Standing RWPs should not be approved for periods longer than one year.

4. RWPs shall be updated if radiological conditions change to the extent that protective requirements need modification.

5. RWPs should be posted at the access point to, or be available in, the radiological work area.

6. Workers shall acknowledge, by signature or through electronic means where automated access systems are in place, that they have read, understand, and will comply with the RWP before initial entry into the area and after any revisions to the RWP.

7. The degree of personnel entry control for radiological areas shall be commensurate with existing and potential radiological hazards within the area.

8. An alternative formal mechanism, such as written procedures or experiment authorizations, may be used in lieu of an RWP as the administrative control over radiological work activities. If an alternative mechanism is used, it should meet the requirements of this Article and Articles 321 and 323.

9. RWPs for training exercises may be prepared in a way that will not compromise the location or precise subject matter of a training scenario. Students shall be given only the information they need to safely enter and perform required tasks in a temporary training exercise radiation area. Trainers should permit their students to read and sign the RWP. Training staff and supporting RCTs shall satisfy Article 334 requirements. Training personnel should notify the RSPC in advance to provide necessary RCT support during the exercise. Training shall not be conducted within actual High Radiation Areas, Very High Radiation Areas, High Contamination Areas, or Airborne Radioactivity Areas.

10. RWPs for classified operations are not required to include classified information. 


\section{Radiological Work Permit Preparation}

1. The responsibility for ensuring adequate planning and control of work activities resides with line management. The TO that is assigned the safety coordination responsibility for a planned activity or for a work area is responsible for generating the RWP. Review and concurrence is required by all TO RadCon Managers who have participating employees for the planned activity or for the work area.

2. The RWP should be based on current radiological surveys and anticipated radiological conditions.

3. The RWP, including any revisions or extensions, shall be approved by the TO RadCon Manager responsible for the planned activity or work area and all TO RadCon Managers whose personnel will be signing in on the RWP.

\section{Pre-Job Briefings}

1. Pre-job briefings should be held before the conduct of work anticipated to exceed the trigger levels identified in Article 312.5. The NNSA/NSO TO having responsibility for radiological work should conduct these briefings.

2. The pre-job briefing should include the following information:
a. The scope of work to be performed
b. The radiological conditions of the workplace
c. The procedural and RWP requirements
d. Any special radiological control requirements
e. Any radiologically limiting conditions, such as contamination or radiation levels that may void the RWP
f. The radiological control hold points
g. Any communications and coordination with other groups
h. The emergency response provisions

3. Pre-job briefings should be conducted by the cognizant work supervisor.

4. Workers and supervisors directly participating in the job, cognizant radiological control personnel, and representatives from involved support organizations should attend the briefing.

5. A summary of topics discussed and attendance at the pre-job briefing should be documented. 


\section{Personal Protective Equipment and Protective Clothing}

References in this manual to the use of PPE and PC pertain only to radiological work activities, operations, or areas. The issue and use of PPE for nonradiological situations falls outside the scope of this manual.

1. Personnel shall wear PC during the following activities:
a. Handling of contaminated materials with removable contamination in excess of Table 2-2 levels
b. Work in Contamination, High Contamination, and Airborne Radioactivity Areas
c. As directed by the RCO or as required by the RWP

2. Launderable PC designated for radiological work should be:
a. $\quad$ Marked according to Article 461.
b. Used only for radiological work.

3. Workers should proceed directly to the radiological work area after donning PPE and PC.

4. General guidelines for PC selection and use are provided in Appendix 3B and in Table 3B-1.

5. The use of lab coats as PC is appropriate for limited applications where the potential for personal contamination is limited to the hands, arms, and upper, front portion of the body. Lab coats should not be used as PC for performing physical work activities in Contamination, High Contamination, or Airborne Radioactivity Areas.

6. Instructions for donning and removing PC should be provided at the dress-out and step-off pad areas for areas that are routinely accessed.

7. Company-issued clothing, other than PCs, should be considered the same as personal clothing.

\section{PART 3 ENTRY AND EXIT REQUIREMENTS}

\section{Controlled Areas}

Completion of General Employee Radiological Training (GERT) is required for unescorted entry into Controlled Areas. 
The following paved roads and adjacent parking lots and access ways within posted Controlled Areas are not part of the Controlled Areas:

- Airport Road

- Buckboard Mesa Road

- Cane Spring Road

- Circle Road

- East Mesa Road
- Holmes Road

- Mercury Highway

- Pahute Mesa Road

- Rainier Mesa Road

- Stockade Wash Road
- Tippipah Highway

- 3-03 Road between Mercury Highway and Area 3 Radioactive Waste Management Site

\section{Radioactive Material Areas and Underground Radioactive Material Areas}

1. RW-I training shall be required for working with radioactive material or for unescorted entry into RMAs and URMAs where the individual is likely to receive more than 100 mrem in a year.

2. GERT shall be required for unescorted entry into RMAs and URMAs in which the individual is likely to receive less than 100 mrem in a year.

334 Radiation, High Radiation, and Very High Radiation Areas

1. The minimum requirements for unescorted entry into Radiation Areas shall include RW-I training and should include the following:
a. Worker's signature on the RWP, as applicable
b. Primary personnel dosimetry

2. Physical controls to prevent inadvertent or unauthorized access to High and Very High Radiation Areas shall be maintained according to Appendix $3 \mathrm{~A}$.

3. The minimum requirements for entry into High Radiation Areas shall include the following:

a. $\quad$ RW-I or RW-II training according to Article 632.2

b. Worker's signature on the RWP

c. Primary and supplemental dosimeters or other means to immediately estimate whole body dose

d. Survey meter or dose-rate indicating device available at the work area

e. Area monitoring, as necessary, during access to determine the exposure rates to which the individuals are exposed

f. Training according to Article 655 for Radiographers and Radiation-Generating Device (RGD) Operators

4. Workers shall be prevented from entry into Very High Radiation Areas. A survey shall be made before the first entry into the area after the source has been secured or shielded to verify the very high radiation field has been terminated. 
5. The number, issue, and use of keys shall be strictly controlled by facility personnel where locked entryways are used to control access to High and Very High Radiation Areas.

6. Physical access controls for High and Very High Radiation Areas generated by source ranges, sealed source radiography, or RGDs should be checked semiannually when in operation. When not in operation, physical access controls should be tested before each use of the facility.

7. Written authorizations shall be required to control entry into and permit work to be performed within radiological areas. These authorizations shall specify radiation protection measures commensurate with the existing and potential hazards.

\section{Contamination, High Contamination, and Airborne Radioactivity Areas}

1. The minimum requirements for unescorted entry into Contamination Areas shall include the following:
a. RW-Il training
b. Worker's signature on the RWP
c. PC
d. Personnel dosimetry, when specified on the RWP

2. The minimum requirements for entry into High Contamination or Airborne Radioactivity Areas shall include the following:
a. RW-II training
b. Worker's signature on the RWP
c. PC
d. Respiratory protection, when specified by the RWP
e. Pre-job briefing
f. Personnel dosimetry, when specified on the RWP

3. Personnel exiting Contamination, High Contamination, or Airborne Radioactivity Areas shall:

a. Remove PC as specified in Appendix 3B. PC may be removed at the exit from the Contamination Area rather than the exit from the High Contamination to the Contamination Area, if both areas have the same exit point to the uncontaminated area.

b. Perform whole-body monitoring when entering an uncontaminated area to detect personnel contamination according to Article 338. 
4. Exit points from Contamination, High Contamination, or Airborne Radioactivity Areas that are routinely accessed should include the following:

a. Step-off pad located outside the exit point, contiguous with the area boundary

b. Step-off pads maintained free of radioactive contamination

c. Designated containers inside the area boundary for the collection of PC and equipment

d. Contamination-monitoring equipment located as close to the step-off pad as background radiation levels permit

5. Written authorizations shall be required to control entry into, and permit work to be performed within, radiological areas. These authorizations shall specify radiation protection measures commensurate with the existing and potential hazards.

\section{Entry Requirements for Members of the Public}

1. Procedures shall identify area entry requirements and access restrictions for members of the public.

2. Members of the public may enter the following areas if properly escorted:
a. Controlled Areas
b. RMAs

3. Members of the public shall be prevented from entering Very High Radiation Areas and should be prohibited access to Radiation, High Radiation, Contamination, High Contamination, and Airborne Radioactivity Areas.

\section{Controlling the Spread of Contamination}

Controls shall be implemented as necessary to prevent the spread of removable contamination outside of Contamination Areas, High Contamination Areas, and Airborne Radioactivity areas under normal operating conditions. The following measures should be used as appropriate to prevent the spread of contamination across the boundary of Contamination Areas, High Contamination Areas, and Airborne Radioactivity Areas:

1. Use solid barriers to enclose areas wherever practicable.

2. Mark and secure items such as hoses and cords that cross the boundary.

3. Control and direct airflow from areas of lesser to greater removable contamination or airborne radioactivity.

4. Use engineered controls and containment devices. 


\section{Monitoring for Personnel Contamination}

1. Individuals exiting Contamination, High Contamination, or Airborne Radioactivity Areas shall be monitored, as appropriate, for the presence of surface contamination.

2. Where monitoring cannot be performed at the exit from Contamination Areas, High Contamination Areas, or Airborne Radioactivity Areas (e.g., due to high background radiation levels), personnel should:

a. Remove all protective equipment and clothing at the exit.

b. Proceed directly to the nearest designated monitoring station or call for RCO support.

c. Perform a whole-body survey or exit through a portal monitor.

3. Personnel monitoring should be performed after removal of PC and before washing or showering.

4. Personnel monitoring shall be performed using instruments that meet the minimum detection requirements of Article 551.11.a. Guidelines for personnel monitoring are provided in Appendix 3C. Individuals who have received instruction in proper monitoring procedures may be authorized by the TO/RCO to self-monitor.

5. Personal items, such as notebooks, papers, and flashlights, shall be subject to the same monitoring requirements as the person carrying them.

6. Instructions for personnel monitoring should be posted adjacent to personnel monitoring instruments unless monitoring is to be performed by a qualified RCT.

7. The personnel monitoring requirements contained in this Article are not applicable at those facilities that contain only radionuclides, such as tritium, that cannot be detected by currently available hand-held or automated monitoring instrumentation. At such facilities, other appropriate methods should be used to detect personnel contamination.

\section{PART 4 RADIOLOGICAL WORK CONTROLS}

\section{General}

Radiological work activities shall be conducted as specified by the controlling written authorization [see 10 CFR 835.501(d)].

\section{Work Conduct and Practices}

1. Contamination levels caused by ongoing work should be monitored. 
2. Tools and equipment should be inspected to verify operability before being taken into Contamination, High Contamination, or Airborne Radioactivity Areas.

3. The use of radiologically clean tools or equipment in Contamination, High Contamination, or Airborne Radioactivity Areas should be minimized.

4. Hoses and cables entering the contaminated area should be secured to prevent the spread of contamination or safety hazards.

5. The identity of components and systems should be verified before use.

6. Where practicable, parts and components should be removed to areas with low dose rates to perform work.

7. Requirements for area cleanup should be included in the technical work documents. Work activities should not be considered complete until support material and equipment have been removed.

8. Smoking, eating, or chewing shall not be permitted in Contamination, High Contamination, or Airborne Radioactivity Areas to minimize intakes of radioactive material by personnel. When a potential exists for personnel heat stress, drinking water may be permitted within a Contamination Area under the following documented conditions and controls:

a. The potential for heat stress cannot be reduced by the use of administrative or engineered controls.

b. $\quad$ All drinking is from approved containers or sources.

c. At a minimum, workers' hands and faces are monitored for contamination before drinking.

d. The applicable requirements and controls are described in approved procedures.

\section{Logs and Communications}

1. Radiological control personnel should maintain logs to document status of work activities and other relevant information.

2. Radiological control personnel should review logs and receive a turnover briefing from the personnel they are relieving during continuous or extended daily operations.

\section{Review of Work in Progress}

1. Work supervisors should review work activities to ensure prescribed radiological controls are being implemented.

2. Radiological control personnel should review the adequacy of radiological work practices, postings, and area controls in the workplace. 


\section{Radiological Stop Work Authority}

1. Any worker has the authority and responsibility to stop radiological work activities for any of the following reasons:
a. Inadequate radiological controls
b. Radiological controls not being implemented
C. Radiological control hold point not being satisfied

2. Once radiological work has been stopped, it shall not be resumed until proper radiological controls have been reestablished.
a. Resumption of radiological work requires the approval of the line manager and the TO RadCon Manager responsible for the work. This approval may be delegated in writing.
b. Resumption of operations after a dose was received in excess of the limits specified in Table 2-1 requires the approval of NNSA/NSO.

\section{Response to Abnormal Situations}

1. Response to increasing or unanticipated radiation levels, as identified by a supplemental dosimeter, area radiation monitor alarm, or by the assigned RCTs, should include the following actions:
a. Stop work
b. Alert others
C. Exit the area immediately
d. Notify radiological control personnel.

2. Response to a spill of radioactive material should include the following actions:
a. Check for injuries.
b. Stop or secure the operation causing the spill.
c. Warn others in the area.
d. Isolate the spill area if possible.
e. Minimize individual exposure and contamination.
f. Secure unfiltered ventilation.
g. Notify radiological control personnel.

3. Radiological control personnel will investigate abnormal situations and take action, as necessary. 


\section{Controls for Bench-Top Work, Laboratory Fume Hoods, Sample Stations, and Glove Boxes}

The following requirements are applicable to radiological work that has the potential to generate radioactive contamination.

1. The following controls apply to localized bench-top and laboratory-fume-hood operations:
a. PC shall, at a minimum, include lab coats and gloves. Gloves should be secured at the wrist, as necessary.
b. Shoe covers should be considered based on the potential for floor contamination.
c. Workers should monitor their hands during work.
d. Upon completion of work or before leaving the area, workers shall monitor those areas of their body that are potentially contaminated. At a minimum, this includes hands, arms, and front portions of the body.

2. The following controls apply to sample-station operations:

a. PC shall include lab coats and gloves, at a minimum. Gloves should be secured at the wrist, as necessary.

b. Shoe covers should be considered based on the potential for floor contamination.

c. If there is a potential for splashing or for airborne radioactivity, such as when taking pressurized samples, additional controls such as rubber aprons, face shields, full PC, or respiratory protection should be instituted.

d. Workers should monitor their hands during work.

e. Upon completion of work or before leaving the area, workers shall monitor those areas of their body that are potentially contaminated. At a minimum, this includes hands, arms, and front portions of the body. Workers should perform a whole-body survey when required by the RWP or its equivalent.

3. The following controls apply to glove-box operations:

a. Glove boxes should be inspected for integrity and operability before use.

b. Glove boxes should be posted to identify whole-body and extremity dose rates.

c. PC shall include lab coats and gloves, at a minimum. Gloves should be secured at the wrist, as necessary.

d. Shoe covers should be considered based on the potential for floor contamination.

e. Workers should monitor their hands during work.

f. Upon completion of work or before leaving the area, workers shall monitor those areas of their body that are potentially contaminated. At a minimum, this includes hands, arms, and feet. Workers should perform a whole-body survey when required by the RWP or its equivalent. 


\section{PART 6 SPECIAL APPLICATIONS}

\section{Plutonium Operations}

DOE Standard DOE-STD-1128-2008, "Guide of Good Practices for Occupational Radiation Protection in Plutonium Facilities," should be considered for plutonium operations. The guide provides specific direction related to dosimetry, radiological monitoring, instrumentation, contamination control, and applicable radiological control procedures.

\section{Uranium Operations}

DOE-STD-1136-2009, "Guide of Good Practices for Occupational Radiological Protection in Uranium Facilities," should be considered for uranium operations. The guide provides specific direction related to management controls, radiological monitoring, instrumentation, contamination control, and internal and external exposure controls.

\section{Tritium Operations}

DOE Handbook DOE-HDBK-1129-2008, "Tritium Handling and Safe Storage," should be considered for tritium operations. This handbook provides specific guidance related to internal dosimetry, contamination and air monitoring, tritium containment practices and techniques, and PPE and PC.

\section{Accelerator Operations}

Stanford Linear Accelerator Center SLAC-327, "Health Physics Manual of Good Practices for Accelerator Facilities," should be considered for accelerator operations. The manual provides specific guidance related to dosimetry, radiological monitoring, shielding design, use of interlocks, and procedures and administrative controls. Consideration should be given to the information provided in DOE O 420.2B, "Safety of Accelerator Facilities."

\section{Radiographic Sealed Sources and Radiation-Generating Devices}

Radiological training requirements for RGD operators are contained in Article 655. The following provisions shall apply to RGDs operated within NNSA/NSO:

1. American National Standards Institute ANSI N43.3, "American National Standard for General Radiation Safety-Installations Using Non-Medical X-Ray and Sealed Gamma-Ray Sources, Energies up to $10 \mathrm{MeV}$," establishes guidelines for operations involving the irradiation of materials and onsite operations involving devices other than sealed sources. 
2. ANSI N43.2, "Radiation Safety for X-Ray Diffraction and Fluorescence Analysis Equipment," establishes guidelines for operations involving the following devices:
a. Analytical diffraction and fluorescence
b. Sealed source irradiators used for flash $\mathrm{x}$-ray diffraction studies

3. Line management in conjunction with the RCO should establish the radiological control requirements for incidental x-ray devices such as electron microscopes and electron-beam welders.

4. Devices for medical use shall be registered with the appropriate regulatory agency.

5. Control requirements for radiographic devices include the following:

a. Onsite operations with devices containing sealed sources should be conducted according to the requirements contained in 10 CFR 34, "Licenses for Industrial Radiography and Radiation Safety Requirements for Industrial Radiographic Operations."

(1) Permanent radiographic installations, structures, or areas in which radiography is regularly performed should be equipped with control devices to protect against unauthorized or accidental entry.

(2) Temporary radiographic operations that are performed in locations that were not designed for radiography and do not contain built-in physical or engineered controls should have the entire radiation exclusion area barricaded and/or roped off to prevent inadvertent personnel access. Additionally, positive control of High Radiation Areas and Very High Radiation Areas should be demonstrated by the use of visual surveillance and/or locked entryways. This visual control should be demonstrated from the time the area is cleared until radiography is completed and the source has been secured. Person(s) performing visual control should have no other responsibility during the radiography operation and should be person(s) other than the radiographers actually involved in performing the radiography.

b. Onsite operations conducted by offsite contractors shall be approved by line management and are coordinated with the RSPC or TO RCO. This process shall ensure the contractor has a valid NRC or Agreement State license and that their operational and emergency procedures are current and available.

6. Safety devices and interlocks at fixed installations shall be operational before and during generation of a radiation field. Operational status shall be verified by testing at least semiannually. 


\section{PART 8 DESIGN AND CONTROL}

\section{Radiological Design Criteria}

The following design objectives are applicable during the design of new facilities and modifications of existing facilities. Additional design criteria are provided in DOE O 420.1B.

1. For areas of continuous occupancy (2,000 hours per year), the design objective shall be to maintain the average exposure level ALARA below 0.5 millirem per hour. If occupancy is not continuous, the design objective shall be to maintain doses ALARA and below 20 percent of the occupational dose limits provided in Table 2-1.

2. For control of airborne radioactivity, the design objective shall be to avoid releases to the work place atmosphere under normal conditions and, under any conditions, to control inhalation by workers to levels that are ALARA. Confinement and ventilation shall normally be used.

3. For materials used in facility construction and modification, the design objective shall be to select materials that facilitate operations, maintenance, decontamination, and decommissioning. Components should be selected to minimize the buildup of radioactivity. Control of contamination should be achieved by containment of radioactive material.

4. In justifying facility design and physical controls, optimization methods shall be used.

5. Support facilities should be provided for donning and removing PC and for personnel monitoring, when required.

6. A neutron radiation weighting factor of 20 for conditions of unknown spectra (or doubling of the neutron quality factor associated with known neutron energies) should be used for design purposes only. Design analyses based on these neutron quality factors are intended to estimate the additional construction cost resulting from neutron quality factor increases. The results of these analyses should be used to ascertain the economic feasibility of incorporating such modifications in the final design. The quality factor is not to be used for determining individual equivalent doses.

7. Existing facility designs that have office space and lunchrooms or eating areas within radiological areas or Controlled Areas require special considerations. Generally:

a. Locating lunchrooms or eating areas, restrooms, drinking fountains, showers, and similar facilities and devices is strongly discouraged within these areas.

b. Locating office spaces within these areas is strongly discouraged; to the extent that such space is essential to support radiological work, steps should be taken to preclude unnecessary occupancy. 
8. Facilities currently under construction should be evaluated and the above criteria applied where practicable.

9. See DOE-STD-1189-2008, "Integration of Safety into the Design Process," for information on the procedures required for design of new nuclear facilities or major modification of other facilities.

10. To ensure adequate protection of the work force, planning for radiological work should also include consideration of all other workplace hazards (e.g., industrial hygiene, chemical safety, fire safety, electrical safety); consistent with the principles of Integrated Safety Management as discussed in Article 118 and as required by 10 CFR 851, "Worker Safety and Health Program."

\section{Control Procedures}

1. Administrative control and procedural requirements shall be developed and implemented as necessary to supplement facility design features, particularly when the design of existing facilities does not conform to current standards [see 835.1001(b)]. Administrative control procedures include access control measures, RWPs, and technical work documents.

2. Written procedures shall be developed as necessary to ensure compliance with the provisions of this manual that are derived from 10 CFR 835 . These procedures shall be commensurate with the radiological hazards created by the activity and the education, training, and skills of the individuals who are exposed to these hazards [see 835.104].

3. Written authorizations, including specific radiation protection measures, shall be required to control entry into and work within radiological areas [see 835.501(d)]. These authorizations may include RWPs, technical work documents, administrative procedures, and other administrative controls.

4. The combination of engineered controls and administrative control procedures shall be sufficient to ensure that, during routine operation, the Table 2-1 dose limits for radiological workers are met and to ensure doses are ALARA [see 835.1003(a)]. 


\section{Appendix 3A}

\section{PHYSICAL ACCESS CONTROLS FOR HIGH AND VERY HIGH RADIATION AREAS}

1. One or more of the following features should be used for each entrance or access point to a High Radiation Area and shall be used for each entrance or access point to a High Radiation Area where radiation levels exist such that a person could exceed a whole-body dose of 1 rem in any one hour [see 835.502(b)]:

a. A control device that prevents entry to the area when high radiation levels exist or upon entry causes the radiation level to be reduced below that level defining a High Radiation Area

b. A device that functions automatically to prevent the use or operation of the radiation source or field while personnel are in the area

c. A control device that energizes a conspicuous visible or audible alarm signal so that the person entering the High Radiation Area and the supervisor of the activity are made aware of the entry

d. Entryways that are locked, except during periods when access to the area is required, with positive control over each entry

e. Continuous direct or electronic surveillance that is capable of preventing unauthorized entry

f. A control device that automatically generates audible and visual alarm signals to alert personnel in the area before use or operation of the radiation source and in sufficient time to permit evacuation of the area or activation of a secondary control device that will prevent the use or operation of the source.

2. In addition to the above requirements, additional measures shall be implemented to ensure personnel are not able to gain access to Very High Radiation Areas [see 835.502(c)].

3. Physical access controls over High and Very High Radiation Areas shall be established in such a way that they do not prevent a person from leaving the area [see 835.502(d)]. 


\section{Appendix 3B}

\section{CONTAMINATION CONTROL PRACTICES}

\section{A. Selection of Protective Clothing (PC)}

Workers shall inspect PC prior to use for tears, holes, or split seams that would diminish protection. Any defective items shall be replaced.

1. PC as prescribed by the RWP should be selected based on the contamination level in the work area, the anticipated work activity, worker health considerations, and regard for nonradiological hazards that may be present. Table 3B-1 provides general guidelines for selection.

2. Cotton glove liners may be worn inside gloves for comfort, but should not be worn alone or considered as a layer of protection. Surgical-style gloves may be worn alone to minimize contamination potential of the hands under certain conditions requiring manual dexterity.

3. Shoe covers and gloves should be sufficiently durable for the intended use. The appropriate safety gear should be worn for work activities requiring additional strength, abrasion resistance, or when required by other, nonradiological safety procedures.

4. Personnel working in Contamination Areas use company-issued hard hats designated for normal use when protective headgear is required. If these become contaminated, they are either decontaminated to below Table 2-2 limits or removed from service.

5. Shoe covers and gloves should be secured or taped at the coverall legs and sleeves when necessary to prevent worker contamination. Tape should be tabbed to permit easy removal.

6. Supplemental pocket or electronic dosimeters should be worn outside the PC, in a manner accessible to the worker. Workers should protect such dosimeters from contamination by placing them in an outer coverall pocket or in plastic bags or pouches. 
Appendix 3B (continued)

Table 3B-1 Guidelines for Selecting Protective Clothing

\begin{tabular}{|c|c|c|c|}
\hline \multirow[b]{2}{*}{$\begin{array}{l}\text { WORK } \\
\text { ACTIVITY }\end{array}$} & \multicolumn{3}{|c|}{ REMOVABLE CONTAMINATION LEVELS } \\
\hline & $\begin{array}{c}\text { LOW } \\
\text { (1 to } 10 \text { times } \\
\text { Table } 2-2 \text { values) }\end{array}$ & $\begin{array}{c}\text { MODERATE } \\
\text { (10 to } 100 \\
\text { times } \\
\text { Table } 2-2 \text { values })\end{array}$ & $\begin{array}{c}\text { HIGH } \\
\text { (> } 100 \text { times } \\
\text { Table } 2-2 \text { values })\end{array}$ \\
\hline Routine & $\begin{array}{l}\text { Full set of PC or labcoats, } \\
\text { shoecovers, and gloves if } \\
\text { appropriate }\end{array}$ & Full set of PC & $\begin{array}{l}\text { Full set of PC, double } \\
\text { gloves, double shoe } \\
\text { covers }\end{array}$ \\
\hline Heavy work & Full set of PC, work gloves & $\begin{array}{l}\text { Double set of } \\
\text { PC, work gloves }\end{array}$ & $\begin{array}{l}\text { Double set of PC, work } \\
\text { gloves }\end{array}$ \\
\hline $\begin{array}{l}\text { Work with pressurized } \\
\text { or large volume } \\
\text { liquids, closed system } \\
\text { breach }\end{array}$ & Full set of nonpermeable PC & $\begin{array}{l}\text { Double set of PC } \\
\text { (outer set non- } \\
\text { permeable), } \\
\text { rubber boots }\end{array}$ & $\begin{array}{l}\text { Double set of PC and } \\
\text { nonpermeable outer } \\
\text { clothing, rubber boots }\end{array}$ \\
\hline
\end{tabular}

Table 3B-1 Notes:

\section{Full Set of PC}
a. Coveralls
b. Cotton glove liners (optional)
c. Inner gloves (surgical, Pylox, or Nitrile)
d. Outer gloves (if required by the RWP)
e. Plastic bags for shoe covers
f. Rubber totes
g. Hood (if required by RWP)
h. Sleeve covers (if required by RWP)
i. Modesty garments, at the option of the wearer, or if required by the RWP (summer or winter weight, depending on environmental conditions)

\section{Double Set of PC}
a. Two pairs of coveralls
b. Glove liners (cotton, optional)
c. Two pairs of gloves
d. Two pairs plastic bags for shoe covers; or one pair each, plastic bags and lightweight rubber boots
e. One pair rubber boots
f. Two hoods
g. Sleeve covers (if required by RWP)
h. Modesty garments, at the option of the wearer, or if required by the RWP 


\section{Appendix 3B (continued)}

\section{B. Removal of PC}

Potentially contaminated PC should be removed without spreading contamination and in particular without contaminating the modesty garment or skin. Workers should be instructed not to touch the skin or place anything in the mouth during PC removal. Instructions for PC removal should be posted at routinely accessed dress out and stepoff areas.

\section{Recommended Sequence for Removing a Full Set of PC at the Step-Off Pad}

Before stepping out of the Contamination Area or Airborne Radioactivity Area to the step-off pad, the worker should:
a. Remove exposed tape.
b. Remove sleeve covers, if applicable.
c. Remove rubber shoe covers.
d. Remove outer gloves (if used).
e. Remove hood from front to rear, as applicable.
f. Remove tape from cuffs.
g. Remove coveralls, inside out, touching inside only.
h. Remove respirator, as applicable.
i. Remove tape or fastener from inner shoe cover (boot bag).
j. Remove each boot bag or shoe cover, placing shoe onto clean step-off pad.
k. Remove inner gloves.
I. Take down barrier closure, as applicable.
m. Remove cotton glove liners, if worn.
n. Commence whole-body monitoring.
o. Monitor badge and dosimeter for contamination.
p. Replace barrier closure, as applicable.

The sequence for the removal of primary and supplemental dosimetry is dependent upon where the dosimetry was worn and the potential for contamination. The sequence for the removal of respirators may be altered if it is determined that the potential for inhalation of airborne contamination or the spread of surface contamination is reduced by keeping respirators on until PCs have been removed.

TOs may specify an alternate PC removal sequence or instructions provided that an equivalent level of protection is provided to the worker. 


\section{Appendix 3B (continued)}

\section{Recommended Sequence for Removing a Double Set of PC Using Two Step-Off Pads}

Before stepping to the first step-off pad, the worker should:

a. Remove exposed tape.

b. Remove sleeve covers, if applicable.

c. Remove outer rubber overshoes.

d. Remove each outer glove.

e. Remove hoods from front to rear.

f. Remove tape from cuffs.

g. Remove outer coveralls, inside out, touching inside only.

h. Remove respirators, as applicable.

i. Remove tape from inner coveralls.

j. Remove each outer shoe cover, stepping on first step-off pad as each is removed.

Before stepping to the second step-off pad, the worker should:

k. Remove inner coveralls, inside out, touching inside only.

l. Remove tape or fastener from inner shoe cover.

m. Remove each inner shoe cover, placing shoe on clean outer step-off pad.

n. Remove inner rubber gloves.

o. Remove cotton glove liners.

p. Take down barrier closure, as applicable.

q. Commence whole-body monitoring. Monitor badge and dosimeter for contamination.

r. Replace barrier closure, as applicable.

The sequence for the removal of primary and supplemental dosimetry is dependent upon where the dosimetry was worn and the potential for contamination. The sequence for the removal of respirators may be altered if it is determined that the potential for inhalation of airborne contamination or the spread of surface contamination is reduced by keeping respirators on until PCs have been removed.

TOs may specify an alternate PC removal sequence or instructions provided that an equivalent level of protection is provided to the worker. 


\section{Appendix 3B (continued)}

\section{Using Multiple Step-Off Pads}

Multiple step-off pads should be used to control exit from High Contamination Areas.

These pads define interim control measures within the posted area to limit the spread of contamination. The following controls apply:

1. The first step-off pad should be located immediately outside the highly contaminated work area, but still within the posted area.

2. The worker should remove highly contaminated outer clothing prior to stepping on the first step-off pad.

3. Secondary step-off pads, still within the posted area, may be utilized as necessary to restrict the spread of contamination out of the immediate area.

4. The outer step-off pad should be located immediately outside the Contamination Area. 


\section{Appendix 3C}

\section{GUIDELINES FOR PERSONNEL CONTAMINATION MONITORING WITH HAND-HELD SURVEY INSTRUMENTS}

\section{A. GENERAL REQUIREMENTS}

Verify that the instrument is in service, has a valid source check, is set to the proper scale, and the audio output can be heard during monitoring.

1. Hold the probe less than $1 / 2$ inch from the surface being surveyed for beta and gamma contamination, approximately $1 / 4$ inch from the surface for alpha contamination.

2. Move the probe slowly over surface, approximately 2 inches per second.

3. If the count rate increases during monitoring, pause for 5 to 10 seconds over the area to provide adequate time for instrument response.

4. If the count rate increases to a value greater than the pre-established contamination limit or the instrument alarms, remain in the area and notify radiological control personnel.

5. The whole-body survey should take at least two to three minutes.

\section{B. PERFORMANCE OF MONITORING}

1. Monitor the hands before picking up the probe.

2. Perform the survey in the following order:
a. Head (pause at mouth and nose for approximately 5 seconds)
b. Neck and shoulders
c. Arms (pause at each elbow for approximately 5 seconds)
d. Chest and abdomen
e. Back, hips, and seat of pants
f. Legs (pause at each knee for approximately 5 seconds)
g. Shoe tops
h. Shoe bottoms (pause at sole and heel for approximately 5 seconds)
i. Personnel and supplemental dosimeters

3. Return the probe to its holder and leave the area. The probe should be placed on the side or face up to allow the next person to monitor their hands before handling the probe. 


\section{TABLE OF CONTENTS}

Article

Page

PART 1 RADIOACTIVE MATERIAL IDENTIFICATION, STORAGE, AND CONTROL

411 Requirements

412 Radioactive Material Labeling

413 Radioactive Material Packaging

414 Radioactive Material Storage

PART 2 RELEASING AND TRANSPORTING RADIOACTIVE MATERIAL ...............4-3

421 Release to Controlled Areas ........................................................ 4-3

422 Release to Uncontrolled Areas ......................................................4-4

423 Transportation of Radioactive Material............................................ 4-6

PART 3 RADIOACTIVE SOURCE AND RADIATION-GENERATING DEVICE CONTROLS

431 Sealed Radioactive Source Controls ............................................4-7

432 Radiation-Generating Devices........................................................ 4-9

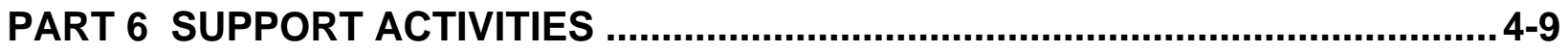

461 Personal Protective Equipment and Protective Clothing ................. 4-9

464 Vacuum Cleaners and Portable Air-Handling Equipment ................4-10 
THIS PAGE INTENTIONALLY LEFT BLANK 


\section{PART 1 RADIOACTIVE MATERIAL IDENTIFICATION, STORAGE, AND CONTROL}

\section{Requirements}

1. Materials in Contamination, High Contamination, or Airborne Radioactivity Areas shall be considered contaminated until surveyed and released. Any equipment or system component removed from a process that may have had contact with radioactive material should be considered internally contaminated until disassembled to the extent required to perform an adequate survey and be shown to be free of contamination exceeding levels shown in Table 4-2. [These survey and release requirements do not apply to Airborne Radioactivity Areas where only gaseous, short-lived (half-life of one hour or less) radioactive products are present.]

2. Except for accountable sealed radioactive sources, according to Appendix $E$ of 10 CFR 835, radioactive material located within Controlled Areas, RMAs, or radiological areas do not require specific labeling or packaging if sufficient information is provided to allow individuals to take appropriate protective actions.

3. Each TO should develop response and notification requirements associated with a loss of radioactive material, including searches, internal investigations, documentation, and reporting. The RCO shall be notified in the event of a loss of radioactive material.

\section{Radioactive Material Labeling}

1. Except as provided in Article 412.2, each item or container of radioactive material shall bear a durable, clearly visible label bearing the standard radiation warning trefoil and the words "Caution, Radioactive Material" or "Danger, Radioactive Material." The label shall also provide sufficient information to permit individuals handling, using, or working in the vicinity of the items or containers to take precautions to avoid or control exposures.

2. The following materials are not subject to labeling requirements:

a. Material used, handled, or stored in radiological areas or RMAs; material surveyed and determined to have removable contamination levels lower than Table 4-2 values in RMAs

b. Items packaged, labeled, and marked according to the regulations of the U.S. Department of Transportation (DOT) or DOE orders governing radioactive material transportation

c. Unused/laundered PCs

d. The quantity of radioactive material is less than one tenth of the values specified in Appendix E of 10 CFR 835 and less than $0.1 \mathrm{Ci}$

e. Inaccessible or accessible only to individuals authorized to handle or use them or to work in the vicinity of the material 
f. Installed in manufacturing, processing, or other equipment, such as reactor components, piping, and tanks

g. The radioactive material consist solely of nuclear weapons or their components

h. Short-lived (half-life of one hour or less) radioactive material generated during an irradiation (i.e., research samples while an experiment is being conducted) that is immediately used

i. Radiological samples that are in the possession of members of the RCO

3. Labels shall have a yellow background with a magenta or black standard radiation symbol. Lettering shall be magenta or black. Radioactive material labels applied to sealed radioactive sources may be excepted from the color specifications.

4. Packaged radioactive material should have the label visible through the package or affixed to the outside.

5. Required labels shall also provide sufficient information to permit individuals handling, using, or working in the vicinity of the labeled material to take appropriate actions to control exposures [see 10 CFR 835.605].

Table 4-1 Labeling Requirements for Radioactive Materials

\begin{tabular}{|c|c|}
\hline ITEM / M ATERIAL & REQUIRED LABELING \\
\hline $\begin{array}{l}\text { Equipment, components, and other } \\
\text { items that are radioactive, potentially } \\
\text { radioactive, or have been exposed to } \\
\text { activation sources }\end{array}$ & $\begin{array}{c}\text { "CAUTION, RADIOACTIVE MATERIAL" } \\
\text { or } \\
\text { "DANGER, RADIOACTIVE MATERIAL" }\end{array}$ \\
\hline $\begin{array}{l}\text { Sealed and unsealed radioactive } \\
\text { sources or associated storage } \\
\text { containers }\end{array}$ & $\begin{array}{c}\text { "CAUTION, RADIOACTIVE MATERIAL" } \\
\text { or } \\
\text { “DANGER, RADIOACTIVE MATERIAL" }\end{array}$ \\
\hline $\begin{array}{l}\text { Equipment, components, and other } \\
\text { items with actual or potential internal } \\
\text { contamination }\end{array}$ & $\begin{array}{c}\text { “CAUTION, INTERNAL CONTAMINATION" } \\
\text { or } \\
\text { "CAUTION, POTENTIAL INTERNAL CONTAMINATION" }\end{array}$ \\
\hline $\begin{array}{l}\text { Components, equipment, or other } \\
\text { items with fixed contamination }\end{array}$ & “CAUTION, FIXED CONTAMINATION” \\
\hline
\end{tabular}

\section{Radioactive Material Packaging}

1. Radioactive material that is outside Contamination, High Contamination, or Airborne Radioactivity Areas and is confirmed or suspected of having removable radioactive contamination levels greater than Table 4-2 values shall be securely wrapped in plastic or placed in a closed container. 
2. Radioactive material with sharp edges or projections should be taped or additionally protected to ensure package integrity.

3. Radioactive material with removable or potentially removable contamination levels in excess of 100 times the Table 4-2 values should have additional packaging controls such as double-wrapping or the use of plastic bags inside containers.

4. Yellow plastic wrapping material should be used for packaging radioactive material. Yellow plastic sheets or bags should not be used for nonradiological purposes.

5. The amount of combustible material used in packaging should be minimized.

\section{Radioactive Material Storage}

1. Items or containers of radioactive material in excess of quantities specified in Appendix E of 10 CFR 835 shall be used, handled, and stored in a designated RMA or radiological area.

2. Decontamination or disposal of radioactive material is the preferred alternative to long-term storage.

3. RMAs should be approved by the responsible TO RadCon Manager or designee.

4. Each RMA should be inspected at least annually.

5. Storing nonradioactive material in an RMA is discouraged.

\section{PART 2 RELEASING AND TRANSPORTING RADIOACTIVE MATERIAL}

\section{Release to Controlled Areas}

1. Except as provided in Articles 421.2 and 421.3, material and equipment in Contamination Areas, High Contamination Areas, and Airborne Radioactivity Areas shall not be released to a Controlled Area if:

a. Removable surface contamination levels on accessible surfaces exceed the removable surface contamination values specified in Table 4-2.

b. Prior use suggests that the removable surface contamination levels on the inaccessible surfaces are likely to exceed the removable surface contamination values specified in Table 4-2.

2. Material and equipment with fixed contamination levels that exceed the total surface contamination values specified in Table 4-2 may be released for use in Controlled Areas outside of radiological areas only under the following conditions: 
a. Removable surface contamination levels are below the removable surface contamination values specified in Table 4-2.

b. The material or equipment is routinely monitored and clearly marked or labeled to alert personnel of the contaminated status.

3. Material and equipment exceeding the removable contamination values specified in Table 4-2 may be conditionally released for movement onsite from one radiological area for immediate placement in another radiological area only if appropriate monitoring is performed and appropriate controls for movement are established and exercised [see 835.1101(b)].

4. Material not immediately removed from Contamination, High Contamination, or Airborne Radioactivity Areas after survey should be controlled to prevent contamination while awaiting release.

5. Results of monitoring for the release and control of material and equipment as required by Articles 421.1, 421.2, and 421.3 shall be documented and maintained.

6. Materials released to Controlled Areas shall be labeled according to Article 412 .

\section{Release to Uncontrolled Areas}

DOE O 5400.5, "Radiation Protection of the Public and the Environment," describes radiological criteria for releasing material to uncontrolled areas. Values consistent with DOE O 5400.5 are provided in Table 4-2. TOs must obtain NNSA/NSO approval to use any limits including those in Table 4-2 for releases to uncontrolled areas. Alternate authorized unrestricted release limits may be approved by DOE/NNSA for material, equipment, or real property with surface contamination levels greater than the Table 4-2 limits. The process to obtain approval is described in DOE O 5400.5 and associated guidance documents.

1. Table 4-2 describes surface contamination criteria for releasing material to uncontrolled areas. This does not apply to materials that are activated or have volumetric or internal contamination.

2. The form FRM-0894, "Radiological Determination for Release of Items," form or TO-equivalent form is used to document material use history/process knowledge to base decisions regarding survey requirements or for uncontrolled release.

3. Material not immediately released after survey should be controlled to prevent contamination while awaiting release.

4. Radiological labeling shall be removed from or defaced on material before release for unrestricted use. 
Table 4-2

Allowable Total Residual Surface Contamination Values in $\mathrm{dpm} / 100 \mathrm{~cm}^{2}$ (Note 1) (from DOE O 5400.5)

\begin{tabular}{|c|c|c|c|}
\hline $\begin{array}{l}\text { RADIONUCLIDE } \\
\text { (See Note 2) }\end{array}$ & $\begin{array}{l}\text { REMOVABLE } \\
\text { (See Note 3) }\end{array}$ & $\begin{array}{l}\text { AVERAGE } \\
\text { (FIXED \& } \\
\text { REMOVABLE) } \\
\text { (See Note 4) }\end{array}$ & $\begin{array}{l}\text { MAXIMUM } \\
\text { ALLOWABLE } \\
\text { (FIXED \& } \\
\text { REMOVABLE) } \\
\text { (See Note 5) }\end{array}$ \\
\hline $\begin{array}{l}\text { Transuranics, }{ }^{125} \mathrm{I},{ }^{129}, \mathrm{I},{ }^{226} \mathrm{Ra},{ }^{227} \mathrm{Ac}, \\
{ }^{228} \mathrm{Ra},{ }^{228} \mathrm{Th},{ }^{230} \mathrm{Th},{ }^{231} \mathrm{~Pa},\end{array}$ & 20 & 100 & 300 \\
\hline $\begin{array}{l}\text { Th-nat, }{ }^{90} \mathrm{Sr},{ }^{126} \mathrm{l},{ }^{131} \mathrm{I},{ }^{133} \mathrm{I},{ }^{223} \mathrm{Ra}, \\
{ }^{224} \mathrm{Ra},{ }^{232} \mathrm{U},{ }^{232} \mathrm{Th},\end{array}$ & 200 & 1,000 & 3,000 \\
\hline $\begin{array}{l}\text { U-naturall, }{ }^{235} \mathrm{U},{ }^{238} \mathrm{U} \text { and associated } \\
\text { decay products, alpha emitters }\end{array}$ & $1,000 \alpha$ & $5,000 \alpha$ & $15,000 \alpha$ \\
\hline $\begin{array}{l}\beta+y \text { emitters (radionuclides with } \\
\text { decay modes other than } \alpha \text {-emission } \\
\text { or spontaneous fission) except }{ }^{0} \mathrm{Sr} \\
\text { and others noted above. (See Note 6) }\end{array}$ & $1,000 \beta+\gamma$ & $5,000 \beta+\gamma$ & $15,000 \beta+\gamma$ \\
\hline Tritium and Tritiated Compounds & 10,000 & N/A & N/A \\
\hline
\end{tabular}

\section{Table 4-2 Notes:}

1. Disintegrations per minute $(\mathrm{dpm})$ means the rate of emission by radioactive material as determined by correcting the counts per minute measured by an appropriate detector for background, efficiency, and geometric factors associated with the instrumentation.

2. Where surface contamination by both alpha- and beta/gamma-emitting radionuclides exist, the limits established for alpha- and beta/gamma-emitting radionuclides apply independently.

3. The amount of removable material per $100 \mathrm{~cm}^{2}$ of surface area should be determined by wiping an area of that size with dry filter or soft absorbent paper, applying moderate pressure, and measuring the amount of radioactive material on the wiping with an appropriate instrument of known efficiency.

When removable contamination on objects of surface area less than $100 \mathrm{~cm}^{2}$ is determined, the activity per unit area should be based on the actual area and the entire surface should be wiped. It is not necessary to use wiping techniques to measure removable contamination levels if direct scan surveys indicate that the total residual surface contamination levels are within the limits for removable contamination. 
4. Measurements of average contamination should not be averaged over an area of more than $1 \mathrm{~m}^{2}$. For objects of less surface area, the average should be derived for each such object.

5. The maximum contamination level applies to an area of not more than $100 \mathrm{~cm}^{2}$.

6. This category of radionuclides includes mixed fission products, including the Sr-90, which is present in them. It does not apply to Sr-90 that has been separated from the other fission products or mixtures where the Sr-90 has been enriched.

\section{Transportation of Radioactive Material}

1. 49 CFR 170 through 180 establish requirements for inspecting and surveying packages, containers, and transport conveyances prior to transport via the public transportation system. These regulations apply to radioactive material transportation in commerce. The RSPC provides assistance in preparing radiological shipments as requested by TOs.

2. DOE O 460.1B, "Packaging and Transportation Safety," and DOE O 460.2A, "Departmental Materials Transportation and Packaging Management," provide requirements that are in conformance with 49 CFR requirements for transportation of radioactive material using any conveyance. 10 CFR 835.1(b)(7) excludes radioactive material transportation activities that are performed according to the applicable transportation requirements (i.e., DOT or DOE requirements) from the requirements of 10 CFR 835 . However, radioactive material transportation (as defined in 10 CFR 835) does not include preparation of materials for shipment, packaging and labeling, or storage of material awaiting transportation. Therefore, these activities shall be conducted according to 10 CFR 835 [see 835.2(a), radioactive material transportation, and 835.1(b)].

3. Table 4-2 removable contamination values are more limiting than 49 CFR requirements and should be used as controlling limits for onsite and offsite transportation when using a conveyance that is owned by DOE. However, when a shipment is received from an offsite destination, by a non-DOE conveyance, the 49 CFR 173 contamination values should be applied to all subsequent onsite transfers to the ultimate on-site destination.

4. Commercial transport conveyances should be radiologically surveyed before loading.

5. Receipt of packages containing radioactive material:

a. When packages containing quantities of radioactive material in excess of Type A quantity (as defined in 10 CFR 71.4) are expected to be received from radioactive material transportation, arrangements shall be made to either: 
(1) Take possession of the package when the carrier offers it for delivery; or

(2) Receive notification as soon as practical after arrival of the package at the carrier's terminal and take possession of the package expeditiously after receiving such notification.

b. Upon receipt from radioactive material transportation, external surfaces of the packages known to contain radioactive material shall be monitored if the package:

(1) Is labeled with a Radioactive White I, Yellow II, or Yellow III label (as specified in 49 CFR 172.403 and 172.436-440), or

(2) Has been transported as low-specific-activity material (as defined in 10 CFR 71.4) on an exclusive-use vehicle (as defined in 10 CFR 71.4), or

(3) Has evidence of degradation, such as packages that are crushed, wet, or damaged.

c. The monitoring required by Article $423.4 \mathrm{~b}$ shall include:

(1) Measurements of removable contamination levels, unless the package contains only special form (as defined in 10 CFR 71.4) or gaseous radioactive material, and

(2) Measurements of the radiation levels, unless the package contains less than a Type A quantity (as defined in 10 CFR 71.4) of radioactive material.

d. The monitoring required by Article 423.4.b shall be completed as soon as practical following receipt of the package, but not later than 8 hours after the beginning of the working day following receipt of the package.

e. $\quad$ The monitoring required by Article 423.4.b is not required for packages transported on site that have remained under the continuous observation and control of a DOE employee or DOE contractor employee who is knowledgeable of and implements required exposure control measures.

6. The site emergency plan should describe appropriate responses for potential onsite radioactive materials transportation accidents.

\section{PART 3 RADIOACTIVE SOURCE AND RGD CONTROLS}

\section{Sealed Radioactive Source Controls}

Sealed radioactive sources shall be used, handled, and stored in a manner commensurate with the hazards associated with operations involving the sources. Withdraw from use any sealed source that is determined to be leaking.

Appendix E of 10 CFR 835 establishes the values for determining accountability of sealed sources.

1. All accountable sealed radioactive sources used at NNSA/NSO facilities shall be registered with the RSPC Sealed Source Program Administrator (SSPA) by the cognizant organization. 
2. Accountable sealed sources and all other sealed radioactive sources having activities exceeding one-tenth of the values of Appendix E of 10 CFR 835 should be labeled in accordance with Article 412 of this document. If the size or configuration of the source precludes application of a suitable label, the label should be attached to the source container or mechanism.

3. The requirements for inventory and leak testing of accountable sealed sources are:

a. Each accountable sealed radioactive source shall be inventoried at intervals not to exceed six months [see 835.1202(a)]. The inventory shall:

(1) Establish the physical location of each accountable sealed radioactive source.

(2) Verify the appropriate postings and labels.

(3) Establish the adequacy of storage locations, containers, and devices.

b. Except for sealed radioactive sources consisting solely of gaseous radioactive material or tritium, each accountable sealed radioactive source shall be leak tested upon receipt, when damage is suspected, and at intervals not to exceed six months. Source leak tests shall be capable of detecting radioactive material leakage $\geq 0.005 \mu \mathrm{Ci}$.

c. An accountable sealed radioactive source that has been removed from service is not subject to periodic leak testing. It must, however, be stored in a controlled location and be inventoried according to Article 431.3a. An accountable sealed radioactive source must be leak tested before restoring it to service.

d. An accountable sealed radioactive source that is located in an area that is unsafe for human entry or is inaccessible is not subject to inventory and leak-testing requirements.

e. An accountable sealed radioactive source found to be leaking radioactive material at any level of measured contamination shall be controlled in a manner that minimizes the spread of contamination.

f. The TO RadCon Manager may extend the time interval in Article 431.3a and $3 \mathrm{~b}$ by a period not to exceed 30 days.

4. Procurement of radioactive sources should be coordinated with the respective TO RCO.

5. Radioactive sources, including radiography sources, shall not be allowed onsite by subcontractors without the prior written approval of the cognizant TO RCO.

6. For accountable sealed sources, each TO shall:

a. Contact the RSPC SSPA for registration before arrival onsite or as soon thereafter as practical.

b. Provide the RSPC SSPA with the source identification, isotope, activity, storage location, source custodian, and leak-test results. 
c. At NNSA/NSO facilities, perform or request from the RSPC semiannual leak-tests and furnish the RSPC SSPA with the results. Each TO maintains documentation of the tests.

d. Inform the RSPC SSPA of changes in the storage location if longer than 60 days.

7. RSPC SSPA shall register all TO accountable sealed radioactive sources. Maintain and update semiannually a source locator report (inventory) listing the location and users of all accountable and registered (licensable) quantities of radioactive materials and/or sources including all sealed sources that meet 10 CFR 835 Appendix E requirements.

8. Upon request the RSPC shall provide leak-test services for NNSA/NSO TOs.

\section{Radiation-Generating Devices}

1. Contact the RSPC Radiation-Generating Device Program Administrator (RGDPA) for registration of any RGD before its arrival onsite or as soon thereafter as possible.

a. For all RGDs, each TO shall submit to the RSPC RGDPA the following information:

(1) Output of the beam

(2) Manufacturer's model and serial number

(3) Leakage rate at maximum power

(4) Documentation of compliance with the appropriate ANSI standards.

(5) Location for RGD operation

b. Each TO shall provide the RSPC RGDPA with updated information on the location of radiation-generating devices.

2. Verify annually for the RSPC RGDPA the physical location of each RGD. Maintain and update an inventory of all RGDs and provide an annual report to TOs.

\section{PART 6 SUPPORT ACTIVITIES}

\section{Personal Protective Equipment and Protective Clothing}

1. Except for disposable, single use items, PC designated for radiological control use should be specifically identified.

2. $\quad$ PC designated for radiological control use should not be used for nonradiological work.

3. PPE and PC should not be stored with personal (street) clothing.

4. Decontaminated respirators shall be surveyed. There shall be no detectable contamination on inner and sealing surfaces, and levels on the outer surfaces shall be below Table 4-2 values before reuse. 
5. Laundered PC should be surveyed using statistically representative sampling and should meet the following criteria before reuse:

a. Beta/gamma radioactivity less than $10,000 \mathrm{dpm} / 100 \mathrm{~cm}^{2}$

b. Alpha radioactivity less than $1,000 \mathrm{dpm} / 100 \mathrm{~cm}^{2}$ for transuranics and other alpha emitters in the same Table 4-2 category and less than $10,000 \mathrm{dpm} / 100 \mathrm{~cm}^{2}$ for uranium

6. PPE and PC should be checked before use. PC should be free of tears, separated seams, deterioration, and damage or PC should be repaired in a manner that provides the original level of protection or discarded.

\section{Vacuum Cleaners and Portable Air-Handling Equipment}

Improper use of vacuum cleaners and portable air-handling equipment may result in the generation of airborne radioactivity, removable contamination, or high dose rates.

1. Vacuum cleaners and portable air-handling equipment used in areas established to control removable surface contamination or airborne radioactivity (except areas where only tritium is present) should be equipped with High-Efficiency Particulate Air (HEPA) filters.

2. HEPA filters used in vacuum cleaners and portable air-handling equipment should meet the applicable efficiency and construction requirements for the devices in which they are installed. The maximum flow rate of the device should not exceed the flow rate at which the HEPA filter was efficiency tested. In addition, the device should be leak tested prior to initial use, when units have undergone any type of service that may compromise the integrity of the HEPA filter or its sealing surfaces, and annually.

3. Vacuum cleaners used for radiological work should be:

a. $\quad$ Marked and labeled in accordance with Article 412.

b. Controlled by written work authorizations.

c. Controlled to prevent unauthorized use.

d. Designed to ensure HEPA filter integrity under conditions of use.

e. Constructed and controlled to prevent unauthorized or accidental access to the inner surfaces of the vacuum.

4. Radiation and contamination surveys should be performed periodically for vacuum cleaners in use and labels on these units should be updated. The frequency of radiation surveys should depend on the specific use of the vacuum cleaner.

5. A nuclear safety review should be performed and documented prior to the use of a vacuum cleaner for fissile material. 


\section{TABLE OF CONTENTS}

$\underline{\text { Article }}$

Page

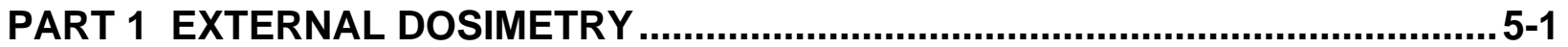

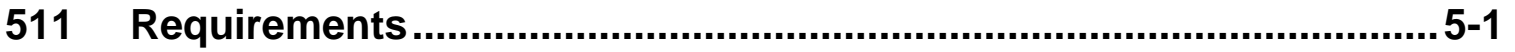

512 Technical Requirements for External Dosimetry .............................5-2

513 Pocket and Electronic Dosimeters ...............................................5-3

514 Area Monitoring Dosimeters .........................................................5-4

515 Nuclear Accident Dosimeters ........................................................ 5-4

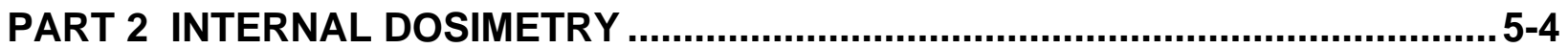

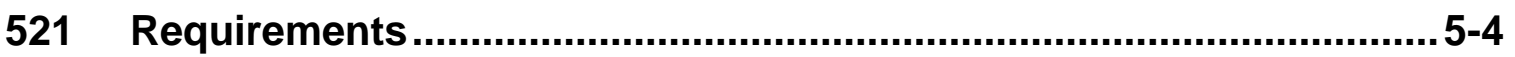

522 Technical Requirements for Internal Dosimetry ............................. 5-5

PART 3 RESPIRATORY PROTECTION PROGRAM........................................... 5-6

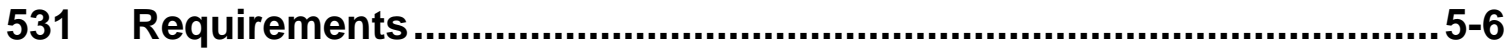

PART 4 HANDLING RADIOLOGICALLY CONTAMINATED PERSONNEL .............5-7

541 Personal Clothing and Skin Contamination .................................... 5-7

542 Contaminated Wounds...............................................................5-7

543 Handling Individuals Exposed to Airborne Radioactivity..................5-8

PART 5 RADIOLOGICAL MONITORING AND SURVEYS ................................... 5-8

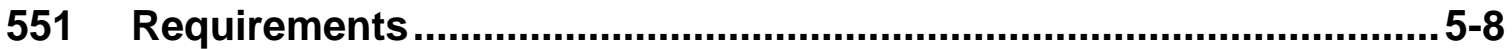

552 Radiation Surveys .................................................................. 5-10

553 Area Radiation Monitors ........................................................... 5-10

554 Contamination Surveys............................................................11

555 Airborne Radioactivity Monitoring .......................................... 5-12

PART 6 INSTRUMENTATION AND CALIBRATION............................................ 5-13

562 Inspection, Calibration, and Performance Tests............................5-13

563 Maintenance .................................................................................5-14

564 Calibration Facilities.................................................................... 5-14 
THIS PAGE INTENTIONALLY LEFT BLANK 


\section{PART 1 EXTERNAL DOSIMETRY}

NNSA/NSO dosimetry shall be worn by personnel when required by the RWP or directed by any TO RCO. The standard NTS thermoluminescent dosimeter measures radiation exposures from gamma, beta, and x-rays. Neutron combination dosimetry shall be worn when required.

\section{Requirements}

1. Individual dosimetry shall be required for the following:

a. Radiological workers who under typical conditions are likely to receive from external sources an effective dose of 100 mrem or more in a year, an equivalent dose to the skin or to any extremity of 5 rem or more in a year, or an equivalent dose to the lens of the eye of 1.5 rem or more in a year or greater than 10 percent of the corresponding limits specified in Table 2-1

b. Declared pregnant workers who are expected to receive from external sources an equivalent dose of 50 mrem or more to the embryo/fetus during the gestation period

c. Occupationally exposed minors and members of the public likely to receive an effective dose of 50 mrem or more in a year

d. Individuals entering a High Radiation Area

2. Dosimeters shall be worn only by those to whom the dosimeters were issued.

3. Individuals should exchange dosimeters for processing as scheduled or upon request and should be restricted by line management from continued radiological work until dosimeters are returned.

4. Individuals should normally wear their primary dosimeter on the chest area between the waist and the neck or in the manner prescribed by radiological control personnel.

5. Users of the NTS Dosimetry Program are permitted to carry their dosimeter offsite.

6. Individuals should not wear dosimeters issued by their resident facilities while being monitored by a dosimeter at another facility. Personnel should not expose their dosimeters to checked baggage inspections, excessive heat, or medical sources of radiation.

7. An individual whose dosimeter is lost, damaged, or contaminated should place work in a safe condition, immediately exit the area, and report the occurrence to the RCO. Reentry of the individual into radiological areas should not be made until a review has been conducted and the RCO has approved reentry. 
8. Individual Responsibilities

It is the responsibility of each individual issued an NTS dosimeter to:

a. Take the issued dosimeter and holder to the appropriate exchange location for dosimeter change-out during the scheduled exchange period of the calendar quarter.

b. Turn in dosimeter more frequently if directed by the RCO or upon termination of employment.

9. TO Responsibilities

All NNSA/NSO TOs shall:

a. Designate to the RSPC one person to be responsible for dosimetry coordination of their employees and subcontractors. This includes locating and retrieving nonreturned dosimeters.

b. Prescribe required dosimetry for radiological activities or areas under their control and ensure that the dosimeters are properly worn.

10. RSPC Responsibilities

The RSPC is responsible for:

a. Administering the external dosimetry program for the NNSA/NSO.

b. Identifying dosimeters that have not been exchanged or returned. After the close of each quarter, the RSPC should issue a nonreturned dosimeter report to the designated person in each organization.

c. Updating the list of TO codes and names of persons within NNSA/NSO organizations who are to receive the dosimeter reports.

\section{Technical Requirements for External Dosimetry}

1. The RSPC shall maintain an external monitoring program that is adequate to demonstrate compliance with Subpart C of 10 CFR 835 and that is accredited in accordance with DOELAP.

2. The Technical Basis document should address dosimeters monitoring radiation outside the scope of DOELAP, such as dosimetry associated with high-energy accelerators and extremity dosimeters. The External Dosimetry Technical Basis Document shall be maintained by the RSPC. 
3. Multiple dosimeters should be issued to individuals to assess effective dose in non-uniform radiation fields. Non-uniform radiation fields exist when the dose to a portion of the whole body will exceed the dose to the primary dosimeter by more than 50 percent and the anticipated whole body dose is greater than 100 mrem. When the radiation field is well characterized and the worker's orientation is known, relocation of the primary dosimeter is permitted in lieu of issuance of multiple dosimeters. Under such conditions, the individual's dosimeter should be relocated to the portion of the whole body likely to receive the highest dose. Dosimeter relocation should be conducted in conformance with facility procedures or specific work authorizations, such as RWPs. The RSPC program documentation should describe the methodology used in determining the dose of record when multiple dosimeters are used.

4. Extremity dosimetry should be used for work in a radiation field where the beta-plus-gamma dose rate in contact with the source of radiation is 10 times greater than the beta-plus-gamma dose rate at $30 \mathrm{~cm}$ from the source and the contact exposure rate is $\geq 50 \mathrm{mR} / \mathrm{hr}$.

5. A dose assessment shall be performed for each instance of a lost, damaged, or contaminated personnel dosimeter, if required.

\section{Pocket and Electronic Dosimeters}

Pocket and electronic dosimeters are supplemental dosimeters that provide real-time indication of exposure to radiation.

1. Pocket or electronic dosimeters shall be issued to personnel before entry into a High Radiation Area (see Article 334 for entry requirements). Alarming dosimeters should be issued to personnel when working in the vicinity of Very High Radiation Areas or potential Very High Radiation Areas.

2. Supplemental dosimeters should be worn co-located with the primary dosimeter.

3. Supplemental dosimeters should be read periodically while in use.

4. Work should be stopped when supplemental dosimeter readings indicate the total dose or rate of exposure is substantially greater than planned. Line management, in consultation with the RCO, shall authorize the continuation of work.

5. The energy dependence and radiation sensitivity of supplemental dosimeters, particularly to low-energy beta and neutron radiation, should be considered in determining their applicability.

6. Electronic dosimeters should be used for entry into high radiation areas or when planned doses greater than 100 mrem in 1 work day are expected. An electronic dosimeter provides an early warning of elevated exposure through the use of alarm set points at specified dose rates and integrated doses. 


\section{Area Monitoring Dosimeters}

A comprehensive area monitoring program may be used to demonstrate that doses outside radiological areas are below the requirements stated in Article 511.1.

1. Area monitoring dosimeters may be used to record and document radiation levels in routinely occupied areas subject to changing exposure rate levels.

2. Area monitoring dosimeter results can be used to support dosimetry investigations.

\section{Nuclear Accident Dosimeters}

1. Facilities possessing sufficient quantities of fissile material to potentially constitute a critical mass, such that the excessive exposure of individuals to radiation from a nuclear accident is possible, shall provide nuclear accident dosimetry for those personnel.

2. Nuclear accident dosimetry shall include the following:

a. A method to conduct initial screening of individuals involved in a nuclear accident to determine whether significant exposures to radiation occurred

b. Methods and equipment for analysis of biological materials

c. A system of fixed nuclear accident dosimeter units

d. A method to ensure that personal nuclear accident dosimeters are worn by all individuals who enter locations in which the requisite quantities of fissile material are contained

\section{PART 2 INTERNAL DOSIMETRY}

\section{Requirements}

1. The following individuals shall participate in an internal dosimetry program:

a. Radiological workers entering radiological areas who under typical conditions are likely to receive intakes resulting in a CED of 100 mrem or more in a year

b. Declared pregnant workers likely to receive intakes resulting in an equivalent dose to the embryo/fetus of 50 mrem or more during the gestation period

c. Occupationally exposed minors and members of the public likely to receive intakes resulting in a CED of 50 mrem or more in a year 
2. The determination of internal dose shall be based on bioassay data rather than air concentration values unless bioassay data are:
a. Unavailable, or
b. Inadequate, or
c. Internal dose estimates based on representative air concentration values are demonstrated to be as or more accurate.

3. Individuals should participate in follow-up bioassay monitoring when bioassay results indicate an intake in the current year with a CED of 100 mrem or more.

4. Individuals shall submit bioassay samples as required by the TO's bioassay program.

5. Individuals shall be notified of positive bioassay results and the results of dose assessments and subsequent refinements related to those results. Dose assessment results shall be provided in terms of rem or mrem.

6. Each TO that performs bioassay sampling shall implement radiological work restrictions for workers that fail to provide samples within the required time frame.

\section{Technical Requirements for Internal Dosimetry}

1. 10 CFR 835 requires accreditation of the internal radiobioassay monitoring program by DOELAP. The RSPC radiobioassay program shall be DOELAP accredited.

2. The internal dosimetry Technical Basis Document shall be maintained by the RSPC.

3. Baseline bioassay monitoring of radiological workers who are likely to receive internal exposures from project-specific radionuclides should be conducted before they begin work that may expose them to internal radiation exposure. This baseline monitoring should be appropriate for specific nuclides based on biological half-life and analysis sensitivity.

4. Bioassay monitoring methods and frequencies should be established for personnel who under typical conditions are likely to receive intakes resulting in a CED > 100 mrem in a year.

5. Management should require termination bioassay monitoring when a person is terminating employment and has not provided an appropriate bioassay sample after concluding work that requires monitoring for internal exposure. It is NNSA/NSO policy to make reasonable attempts to perform bioassay monitoring on terminating employees who meet this criteria. 
6. Bioassay analyses should also be performed when any of the following conditions occur:
a. Facial or nasal contamination is detected that indicates that internal contamination is likely.
b. Workplace air monitoring indicates that intakes exceeding 100 mrem CED are likely.
c. Upon direction of the RCO when an intake is suspected.

7. Levels of intakes that warrant the consideration of medical intervention should be established for site-specific radionuclides. The effectiveness of medical intervention, such as blocking or chelating agents, should be documented using bioassay results.

8. A preliminary assessment of any suspected intakes should be conducted before permitting an employee to return to radiological work.

\section{PART 3 RESPIRATORY PROTECTION PROGRAM}

The requirements for implementing the Respiratory Protection Program and the associated training of personnel are contained in 29 CFR 1910.134, "Respiratory Protection."

\section{Requirements}

1. The respiratory protection program shall be maintained by the RSPC.

2. Respirators shall be issued only to personnel who are trained, quantitative fit tested, and medically qualified to wear the specific type of respirator. Training and qualification testing shall be performed annually. Individuals shall have a current mask fit card before being issued respiratory protection equipment.

3. The RSPC is responsible for providing the following services unless provided by the responsible TO:

a. Fit-testing respirators to each worker who needs to wear such equipment.

b. Respiratory Protection Training.

c. Providing medical evaluations for personnel who need to wear respiratory protection equipment.

d. Issuing respiratory protection equipment.

e. Maintaining controls to issue, use, maintain, repair, and return respirators.

4. Facility safety analyses should not take credit for the use of respiratory protection for routine work involving potential exposure to airborne radioactive materials. 


\section{PART 4 HANDLING RADIOLOGICALLY CONTAMINATED PERSONNEL}

\section{Personal Clothing and Skin Contamination}

1. Survey techniques shall be established to determine the extent of personal clothing or skin contamination.

2. When personal clothing or skin contamination is detected, the TO RCO shall be notified.

3. The extent, amount, and type (alpha, beta/gamma) of radiation involved in personal clothing or skin contamination should be determined before initiating decontamination procedures.

4. Skin decontamination methods should be established for site-specific radionuclides. Contamination levels should be reduced below those specified in Table 4-2. Skin abrasion should be avoided during the decontamination process. Intrusive decontamination methods, such as tissue removal, require medical assistance.

5. A default trigger level of $200,000 \mathrm{dpm} / 100 \mathrm{~cm}^{2}$ skin contamination or 300,000 $\mathrm{dpm} / 100 \mathrm{~cm}^{2}$ clothing contamination has been established for mixed fission products for performance of skin dose assessment. This trigger level shall remain in effect unless the exact radionuclide content has otherwise been specified on the RWP or alternative document.

6. Personnel with skin contamination that triggers the need for dose assessment should be informed of the initial dose estimate to their skin as soon as practicable.

\section{Contaminated Wounds}

1. Emergency medical care should be administered immediately for injuries involving radioactive materials. Medical treatment of injuries takes precedence over radiological considerations.

2. The treatment of contaminated wounds is described in the RSPC's internal dosimetry technical basis document.

3. An injured person should be counseled on the medical and radiological implications resulting from contaminated wounds. The counseling should be performed by senior radiological control and medical professionals. 


\section{Handling Individuals Exposed to Airborne Radioactivity}

Potential intakes of radioactive material are indicated when individuals without respiratory protection are exposed to airborne radioactivity or when respiratory protection has been compromised. If intakes of radioactive material are indicated that could result in an individual receiving a CED greater than $100 \mathrm{mrem}$, the following actions should be taken:

1. Identify individuals potentially exposed to airborne radioactivity.

2. Obtain nasal smears for qualitative indication of intakes where appropriate.

3. Analyze air samples to determine airborne concentrations where appropriate.

4. Determine duration of potential exposure to airborne radioactivity.

5. Perform bioassay appropriate for the type and quantity of radionuclides involved.

6. Evaluate dose prior to permitting the worker to return to radiological work.

\section{PART 5 RADIOLOGICAL MONITORING AND SURVEYS}

\section{Requirements}

1. Monitoring of individuals and areas shall be performed to:

a. Demonstrate compliance with the regulations in 10 CFR 835, Subpart E, "Monitoring of Individuals and Areas."

b. Document radiological conditions.

c. Detect changes in radiological conditions.

d. Detect the gradual buildup of radioactive material.

e. Verify the effectiveness of engineered and administrative controls in containing radioactive material and reducing radiation exposures.

f. Identify and control potential sources of individual exposure to radiation and/or radioactive material.

2. Instruments and equipment used for monitoring shall be:

a. Periodically maintained and calibrated on an established frequency.

b. Appropriate for the type(s), levels, and energies of radiation(s) encountered.

c. Appropriate for existing environmental conditions.

d. Routinely tested for operability.

3. The RCO shall document changes in equipment, techniques, and procedures used for monitoring. 
4. Instruments used to perform radiation surveys shall be readily available and performance checked daily or before operation. When performance checks are not within \pm 20 percent of the expected value, the instrument should be taken out of service. When performance checks are not feasible, such as with instruments used to measure neutrons or tritium, compensatory actions should be established to ensure proper instrument performance.

5. Assessment of radiological conditions should include a sufficient number of survey points to characterize the radiation present and to verify boundaries.

6. Surveys shall be performed before, during, and at the completion of work that has the potential for causing changes in radiation exposure/dose rates or contamination levels.

7. Survey frequencies should be established based on potential radiological conditions, probability of change in conditions, and area occupancy factors.

8. Monitoring results should be reviewed by the cognizant radiological control representative to ensure that the documentation is accurate and complete.

9. Results of latest surveys of radiological areas or survey maps should be posted or otherwise available to inform personnel of the radiological conditions.

10. Monitoring results should be made available to line management and used in support of pre- and post-job evaluations, ALARA preplanning, contamination control, and management of radiological control operations.

11. NNSA/NSO TOs should do the following:

a. Provide instrumentation and methods necessary to detect and accurately assess external and internal radiation hazards associated with their operations or request that the RSPC provide this service. At a minimum, the radiation detection instruments should be capable of measuring levels of total contamination defined in Table 2-2.

b. Perform monitoring for contamination using frisking equipment that under laboratory conditions can detect total contamination of at least the values specified in Table 2-2. Use of automatic monitoring units that meet the above requirements is encouraged.

c. Provide an ambient workplace air monitoring program in occupied areas that are likely to exceed the DAC value given in Appendix A of 10 CFR 835 or 12 DAC-hours in a week.

d. Perform monitoring of airborne radioactivity where an individual is likely to receive an exposure of 40 or more DAC-hours in a year.

e. Provide survey and monitoring records upon request. 
12. The RSPC should:

a. Provide radiation-monitoring services upon request.

b. Provide radiation-detection instruments and calibration services upon request.

c. Provide survey and monitoring records upon request.

d. Provide personnel and equipment decontamination services upon request.

\section{Radiation Surveys}

1. In addition to the requirements of Article 551, routine radiation surveys should be performed according to the following:
a. As often as necessary to document changing conditions in routinely occupied Radiation Areas
b. Upon initial entry and when levels are expected to change in High Radiation Areas
c. Initially and when configuration changes are made to Radiation and High Radiation Area boundaries to ensure that radiation areas do not extend beyond posted boundaries
d. As often as necessary to document changing conditions for RMAs
e. $\quad$ Upon entry into posted Radiation, High Radiation, and Very High Radiation Areas when remotely operated radioactive sources are present, or when it cannot be verified that RGDs have been de-energized

2. Radiation monitoring should include dose-rate measurements of the general area, dose rates at a distance of $30 \mathrm{~cm}$ from the source or surface of interest to evaluate potential whole-body exposures, and dose rates on contact with potential sources of radiation where hands-on work or other direct contact is likely.

3. Surveys should be conducted whenever operations are being performed that might result in personnel being exposed to small intense beams of radiation, such as those generated by shielded x-ray devices or by removal or alteration of shielding.

\section{Area Radiation Monitors}

1. Area radiation monitors (not to include area monitoring dosimeters discussed in Article 514) should be installed in frequently occupied locations with the potential for unexpected increases in dose rates and in remote locations where there is a need for local indication of dose rates prior to personnel entry.

2. Area radiation monitors should not be substituted for radiation exposure surveys in characterizing a workplace. 
3. The need for and placement of area radiation monitors should be documented and assessed when changes to facilities, systems, or equipment occur.

4. In addition to the requirements of Article 562, area radiation monitors should be operability tested at least quarterly to verify any audible-alarm-system operability and audibility under ambient working conditions when so equipped, and operability of visual alarms when so equipped.

5. If installed instrumentation is removed from service for maintenance or calibration, a radiation monitoring program providing similar detection capability should be provided, consistent with the potential for unexpected increases in radiation dose rates. If the circuitry is required to ensure compliance with the high radiation area access control requirements (334.3-e), then the circuitry shall be fail safe (see Appendix 3A.-1)

6. Where an area radiation monitor is incorporated into a safety-interlock system, the circuitry should be such that a failure of the monitor shall either prevent entry into the area or prevent operation of the RGD.

\section{Contamination Surveys}

1. In addition to the requirements of Article 551, routine contamination surveys should be conducted in Contamination, High Contamination, and Airborne Radioactivity Areas as follows:

a. Before transfer of equipment and material from one radiological area to another.

b. Before transfer of equipment and material from High Contamination Areas within radiological areas, unless precautions such as bagging or wrapping are taken before transfer.

c. Daily at Contamination Area control points, change areas, or step-off pads when in use, or per shift in high-use situations, as needed. Temporary, single-use control points or step-off pads established under field conditions and continuously controlled by an RCT may be excluded from this survey.

d. Daily in eating areas located adjacent to Contamination Areas and/or radiological buffer areas to document changing conditions.

e. As needed in routinely occupied Contamination Areas.

f. Upon entry for Contamination Areas that are not routinely entered.

g. During initial entry into a known or suspected Contamination Area, periodically during work, at the completion of the job, or as specified in an RWP.

h. Monthly, in and around areas of fixed contamination.

i. After a leak or spill of radioactive materials.

j. Survey face and hands before allowing personnel to drink. 
2. Contamination surveys should incorporate techniques to detect both removable and fixed contamination.

3. Items with inaccessible surfaces that were located in known or suspected Contamination Areas, and had the potential to become contaminated at levels likely to exceed Table 2-2 values, shall be treated as potentially internally contaminated and are subject to administrative controls unless the items are dismantled and monitored or special survey techniques are used to survey all surfaces.

4. Swipe surveys for removable contamination should be recorded in units of $\mathrm{dpm} / 100 \mathrm{~cm}^{2}$. For swipe surveys of small items covering less than $100 \mathrm{~cm}^{2}$, the results should be recorded in units of dpm per area swiped.

5. Large area wipes are encouraged and should be used to supplement standard swipe techniques in areas generally assumed not to be contaminated, such as entrances to radiological areas. If an evaluation indicates that a wiped area is contaminated, a thorough contamination swipe survey should be performed.

6. Unused facilities are exempt from periodic resurvey.

\section{Airborne Radioactivity Monitoring}

1. Monitoring of airborne radioactivity shall be performed:

a. Where an individual is likely to receive an exposure of 40 or more DAC-hours in a year.

b. As necessary to characterize the airborne radioactivity hazard where respiratory protective devices for protection against airborne radionuclides have been prescribed.

2. Real-time air monitoring shall be performed, as necessary, to detect and provide warning of airborne radioactivity concentrations that warrant immediate action to terminate inhalation of airborne radioactive material.

3. Air sampling equipment should be positioned to measure air concentrations to which persons are exposed. If this cannot be achieved, a program of personal breathing-zone air sampling should be initiated.

4. Air monitoring equipment shall be routinely calibrated and maintained on an established frequency.

5. CAM equipment required by Article 555.2 shall have alarm capability and sufficient sensitivity to alert personnel that immediate action is necessary in order to minimize or terminate inhalation exposures. 
6. A technical basis document should be developed for the airborne radioactivity monitoring program. The technical basis document should provide the basis for air monitor selection, placement, and operation.

7. The proper operation of CAM equipment should be verified daily when in service, and the work area is occupied (e.g., by performing an operational check, or verifying the CAM is operating normally as indicated by "power on," "normal count-rate reading," and no "trouble" or "failure" alarms). Real-time air monitoring equipment operation should be verified weekly by checking for instrument response with a check source or with ambient levels of radon and thoron daughters.

8. Preliminary assessments of air samples using field survey techniques may be performed promptly upon removal of filters from sampling devices. In situations where background levels of radon and thoron daughters interfere with evaluation of alpha air samples, prompt field assessments may not be possible.

9. Air sample results should be evaluated as quickly as practical for determination of the need for respiratory protection, area evacuation, worker intake, or worker relief from respirator use.

\section{PART 6 INSTRUMENTATION AND CALIBRATION}

\section{Inspection, Calibration, and Performance Tests}

1. Radiological instruments shall be used only to measure the radiation for which their calibrations are valid. ANSI N323-A, B, and C requirements should be used for radiological instrumentation calibration. Calibrations should use National Institute of Standards and Technology (NIST)-traceable sources.

2. Calibration procedures should be developed for each radiological instrument type and should include calibration frequency, precalibration requirements, primary calibration requirements, periodic performance-test requirements, calibration record requirements, and maintenance requirements.

3. Pocket and electronic dosimeters and area radiation monitors shall be maintained and calibrated on an established frequency.

4. The effects of environmental conditions on an instrument, including interfering radiation, shall be known before use.

5. Operational tests should be used to assess instrumentation designs that include alarms or that involve a process control. An operational test should be developed to test all components involved in an alarm or trip function and should be performed at least annually. 
6. In unusual and limited situations, it may be necessary to use an instrument in an application other than that envisioned by the manufacturer. Special calibrations should be performed for instrumentation used outside the manufacturer's specifications. The instrument should be adjusted, calibrated, and labeled to identify the special conditions and used only under the special conditions for which it was calibrated.

7. Instruments should bear a label or tag with the date of calibration and the date the calibration expires. Instruments whose calibration has expired should not be available for use; they should be separated and labeled (e.g., "out of service" or "out of calibration").

8. Instruments whose "as found" readings indicate that the instrument may have been used while out of calibration shall be reported to the appropriate RCO. The appropriate RCO should review surveys performed with the instrument while it was out of calibration.

\section{Maintenance}

1. A program for preventive and corrective maintenance of radiological instrumentation should be established and documented.

2. Preventive and corrective maintenance should be performed using components and procedural recommendations at least as stringent as those specified by the manufacturer of the instrument.

3. Radiological instruments should undergo calibration before use following any maintenance or any adjustment that voids the previous calibration. A battery change is not considered maintenance.

\section{Calibration Facilities}

1. Calibration facilities should take the following actions:

a. Locate activities in a manner to minimize radiation exposure to operating personnel and to personnel in adjacent areas.

b. Minimize sources of interference, such as backscatter and non-ionizing radiation during instrument calibration and correct for interferences, as necessary.

c. Operate according to the referenced standards.

d. Generate records of calibration, functional tests, and maintenance according to the referenced standards.

2. For organizations that do not possess or use their own calibration facilities, contracted calibration services should be performed according to the referenced standards. 


\section{TABLE OF CONTENTS}

$\underline{\text { Article }}$

Page

PART 1 RADIOLOGICAL TRAINING AND QUALIFICATION ..........................................6-1

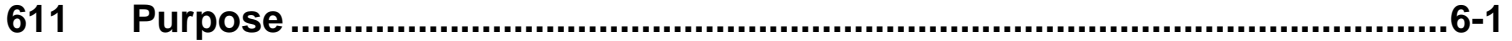

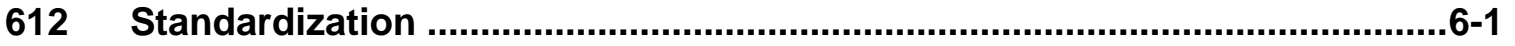

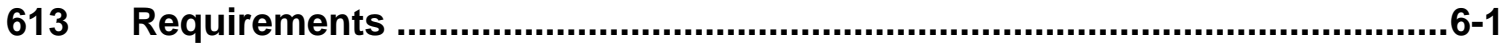

614 Instructor Training and Qualifications ........................................................6-2

PART 2 GENERAL EMPLOYEE RADIOLOGICAL TRAINING.............................................6-3

621 Site Personnel ..........................................................................................

622 Radiological Orientation for Members of the Public .....................................6-3

PART 3 RADIOLOGICAL WORKER TRAINING ..........................................................6-3

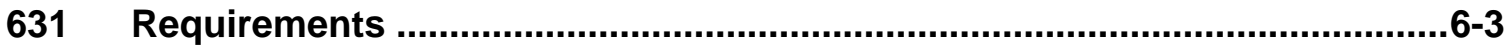

632 Radiological Worker I..............................................................................6-4

633 Radiological Worker II..............................................................................6-5

634 Specialized Radiological Worker Training ...................................................

PART 4 RADIOLOGICAL CONTROL TECHNICIAN QUALIFICATION ...............................6-5

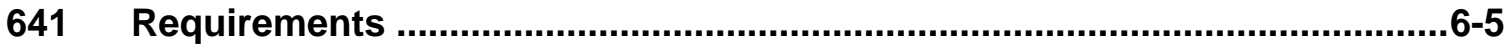

642 Radiological Control Technician...............................................................6-5

643 Qualification Standards for Radiological Control Technicians ...................6-6

644 Oral Examination Boards............................................................................6-6

645 Continuing Training and Requalification ...............................................6-6

646 Radiological Control Technician Supervisors............................................6-7

647 Subcontracted Radiological Control Technicians ...................................6-7

PART 5 OTHER RADIOLOGICAL TRAINING ................................................................6-7

653 Work Planners ..........................................................................................6-7

655 Radiographers and Radiation-Generating Device Operators ......................6-7

656 Emergency Response Personnel.............................................................6-8

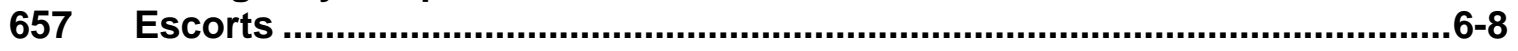


THIS PAGE INTENTIONALLY LEFT BLANK 


\section{PART 1 RADIOLOGICAL TRAINING AND QUALIFICATION}

\section{Purpose}

This chapter establishes the requirements to ensure that personnel have the training to work safely in and around radiological areas and to maintain their individual radiation exposure and the radiation exposures of others ALARA. Training provisions in this chapter apply to individuals entering controlled areas at NNSA/NSO sites and other individuals who are responsible for developing and implementing radiological control measures. Line managers should review each employee's (including subcontractor's) job functions and determine radiological training requirements based on Table 6-1.

\section{Standardization}

1. Standardized core course training material shall be used for GERT, RW-I, RW-II, and RCT training. The standardized core courses are presented and site-specific information is added.

2. DOE-HDBK-1130-2008, "Radiological Worker Training," course training material, supplemented by site-specific training materials, should be used to the extent practicable to satisfy the radiological training requirements.

3. Successful completion of the standardized courses for RW-I, RW-II, and RCT training at another DOE or NNSA site within the past two years shall be recognized where equivalency has been established. Documentation of previous training shall include the individual's name, date of training, topics covered, and the name of the certifying official. Site-specific aspects of the radiological training shall be completed. Site-specific training for GERT, RW-I, and RW-II training may be included with other site orientation training.

4. Training certificates that identify current training status shall be provided. Appropriate measures include electronic databases or wallet-sized training certificates that identify current training status.

5. Changes to the RSPC radiological training material requires the concurrence of the RadCon Managers' Council.

6. TO RadCon Managers or designees may approve equivalent training that meets the requirements of 10 CFR 835.901(c).

\section{Requirements}

1. Examinations for RW-I and RW-II training and RCT qualification shall be used to demonstrate knowledge of the radiation-safety training topics presented in the course material. Examinations should be written; however, the RadCon Manager may approve alternatives to accommodate special needs. Alternative examinations should be equivalent in content to written examinations. The examination process should require: 
a. A minimum score of 80 percent to pass the exam. Failure to achieve the minimum standard upon re-examination (two failures) necessitates repetition of the full training session.

b. That true/false questions not be included.

c. Using questions randomly selected from the question bank.

d. In addition to an examination, RW-I, RW-II, and RCT personnel in training classes shall be required to complete performance demonstrations commensurate with their duties.

2. Workers may challenge RW-I or RW-II training by passing an examination. If unsuccessful in one attempt, the entire RW-I or RW-II training shall be completed.

3. GERT, RW-I, RW-II, and RCT training shall be completed every 24 months.

a. Changes to the program shall be incorporated as they are identified and a decision made by the RadCon Managers' Council whether retraining before the expiration of the 24-month period is needed.

b. The 24-month period may be extended by the TO RadCon Manager, not to exceed 30 days, to meet scheduling needs.

4. Personnel who have successfully completed or maintained current qualifications in a particular radiological training course meet the requirements for a lower-tier radiological training course.

a. GERT courses satisfy the GERT requirements.

b. RW-I courses satisfy the RW-I and GERT requirements.

c. RW-II courses satisfy the RW-II, RW-I, and GERT requirements.

d. RCT qualification satisfies the RCT, RW-II, RW-I, and GERT requirements.

5. RadCon Managers may direct remedial radiological training for individuals who demonstrate lack of knowledge or the skills required to perform work safely.

\section{Instructor Training and Qualifications}

1. All instructors should be qualified in accordance with the TO's Instructor Qualification Program or possess equivalent qualifications.

2. Instructors should have the technical knowledge, experience, and instructional skills required to fulfill their assigned duties.

3. Subject matter experts without instructor qualification may provide training in their areas of expertise. However, these subject matter experts should be qualified as instructors when this occurs routinely. 


\section{PART 2 GENERAL EMPLOYEE RADIOLOGICAL TRAINING}

\section{Site Personnel}

Individuals who may enter Controlled Areas and encounter radiological barriers, postings, or radioactive materials shall complete GERT unless RW-I, RW-II, or RCT training is current. This training shall be successfully completed before receiving occupational radiation dose.

1. GERT includes the standardized core course training materials expanded to include site-specific information.

2. Additional training beyond GERT is necessary for unescorted entry into radiological buffer areas and into radiological areas.

3. Information may be communicated by classroom lecture, videotape, computer-based training, or other applicable methods.

\section{Radiological Orientation for Members of the Public}

Members of the public should be escorted in Controlled Areas. The TO RadCon Manager may approve exceptions to the escort requirements provided that:

1. Appropriate limitations are established on the areas to be entered and the activities to be undertaken.

2. The individual receives enhanced orientation providing information commensurate with the areas to be entered and activities to be undertaken while unescorted.

\section{PART 3 RADIOLOGICAL WORKER TRAINING}

\section{Requirements}

1. RW-I or RW-II training is required for unescorted entry into areas as stated in Table 6-1.

2. Individuals with current RW-I training may be upgraded to RW-II by completing only the additional training. 
Table 6-1 Radiological Training Requirements

\begin{tabular}{|c|c|c|c|}
\hline AREAS & GERT & RW-I & RW-II and RCT \\
\hline Unescorted Entry into Controlled Areas & YES & YES & YES \\
\hline $\begin{array}{l}\text { Unescorted Entry into RMAs and URMAs (less } \\
\text { than } 100 \text { mrem/year) }\end{array}$ & YES & YES & YES \\
\hline $\begin{array}{l}\text { Unescorted Entry into RMAs and URMAs } \\
\text { (greater than } 100 \text { mrem/year) }\end{array}$ & $\begin{array}{l}\text { NOT } \\
\text { PERMITTED }\end{array}$ & YES & YES \\
\hline Working with Radioactive Material & $\begin{array}{l}\text { NOT } \\
\text { PERMITTED }\end{array}$ & YES & YES \\
\hline $\begin{array}{l}\text { Unescorted Entry into Radiological Buffer } \\
\text { Areas }\end{array}$ & $\begin{array}{l}\text { NOT } \\
\text { PERMITTED }\end{array}$ & YES & YES \\
\hline Unescorted Entry into Radiation Areas & $\begin{array}{l}\text { NOT } \\
\text { PERMITTED }\end{array}$ & YES & YES \\
\hline Entry into High Radiation Areas & $\begin{array}{l}\text { NOT } \\
\text { PERMITTED }\end{array}$ & YES & YES \\
\hline Entry into Very High Radiation Areas & $\begin{array}{l}\text { NOT } \\
\text { PERMITTED }\end{array}$ & $\begin{array}{l}\text { NOT } \\
\text { PERMITTED }\end{array}$ & $\begin{array}{l}\text { NOT } \\
\text { PERMITTED }\end{array}$ \\
\hline Unescorted Entry into Contamination Areas & $\begin{array}{l}\text { NOT } \\
\text { PERMITTED }\end{array}$ & $\begin{array}{c}\text { NOT } \\
\text { PERMITTED }\end{array}$ & YES \\
\hline Entry into High Contamination Areas & $\begin{array}{c}\text { NOT } \\
\text { PERMITTED }\end{array}$ & $\begin{array}{l}\text { NOT } \\
\text { PERMITTED }\end{array}$ & YES \\
\hline $\begin{array}{l}\text { Soil disturbing activities in open land areas } \\
\text { posted as URMAs or RMAs }\end{array}$ & $\begin{array}{c}\text { NOT } \\
\text { PERMITTED }\end{array}$ & $\begin{array}{l}\text { NOT } \\
\text { PERMITTED }\end{array}$ & YES \\
\hline Entry into Airborne Radioactivity Areas & $\begin{array}{c}\text { NOT } \\
\text { PERMITTED }\end{array}$ & $\begin{array}{l}\text { NOT } \\
\text { PERMITTED }\end{array}$ & YES \\
\hline
\end{tabular}

\section{Radiological Worker I}

Workers whose job assignments involve working with radioactive materials or entry into Radiation Areas or RMAs and URMAs (greater than 100 mrem/yr) shall complete RW-I training.

1. RW-I training shall use the DOE-standardized core course training materials and, in addition, shall include site-specific information.

2. Unescorted access to High Radiation Areas is permitted upon successful completion of RSPC or equivalent RW-I training. Completing this training does not authorize access to Contamination, High Contamination, or Airborne Radioactivity Areas. See Table 6-1. 


\section{Radiological Worker II}

Workers whose job assignments involve entry to Contamination Areas, High Contamination Areas, and Airborne Radioactivity Areas shall complete RW-II training. See Table 6-1.

1. RSPC RW-I training provides qualifications for entry into High Radiation Areas per 632.2.

2. RW-II training shall use the standardized core course training materials and, in addition, shall include site-specific information and practical factors.

\section{Specialized Radiological Worker Training}

Specialized Radiological Worker Training should be completed for non-routine operations or work in areas with changing radiological conditions. This training is in addition to RW-I or RW-II training and should be provided to personnel planning, preparing, and performing jobs that have the potential for significant radiological consequences. Such jobs may involve special containment devices, the use of mockups, and ALARA considerations.

\section{PART 4 RADIOLOGICAL CONTROL TECHNICIAN QUALIFICATION}

\section{Requirements}

Each RCT shall demonstrate knowledge of the radiation safety training topics commensurate with the hazards in the areas and the required controls, by successful completion of examinations and performance demonstrations prior to performing unsupervised assignments.

Training and qualification of RCTs shall address routine operations and also focus on recognizing and handling situations in both normal and changing radiological conditions. Newly qualified RCTs and those still in training should work with qualified, experienced RCTs.

\section{Radiological Control Technician}

1. Initial RCT qualification requires successful completion of the standardized DOE core course training materials including emphasis on site-specific information (Phase I), on-the-job practical training (Phase II), and an Oral Examination Board or interview (Phase III).

2. RCT candidates who have prerequisite knowledge, such as college credit, operational experience, or related qualifications may satisfy individual sections of the standardized core course training requirements by passing comprehensive challenge examinations. 
3. Entry-level prerequisites should be established to ensure that RCTs meet the standards for education. At a minimum, these standards should include the following:
a. High school education or equivalency
b. Fundamental knowledge of mathematics, physics, chemistry, and science
c. Reading, writing, and comprehension

4. RCTs are encouraged to pursue registration by the National Registry of Radiation Protection Technologists (NRRPT). TOs may give credit toward completing standardized core training requirements for NRRPT registration.

5. Before performing a job function without direct supervision, a trainee with partially completed qualifications shall have completed the qualifications for that task.

\section{Qualification Standards for Radiological Control Technicians}

1. The Qualification Standards from the standardized core course should be supplemented to include site-specific elements.

2. Qualification Standards for the RCT position should include on-the-job training to provide hands-on experience directly applicable to the job.

\section{Oral Examination Boards}

1. An Oral Examination Board should determine the initial qualification and is encouraged for requalification of RCT positions.

2. The RadCon Manager should designate the Board members and appoint a chairperson.

3. The Board constituted to evaluate RCT qualification should be composed of at least three persons to include radiological control staff and/or line management, operations department supervisors, and staff personnel, as applicable.

4. The Board should assess the candidate's response to normal and emergency situations.

\section{Continuing Training and Requalification}

1. Following qualification, RCTs should begin a 24-month cycle of continuing training required for requalification. Biennial requalification requires completing practical training and a comprehensive written examination and may include a final Oral Examination Board or interview. 
2. Continuing training should include written examinations as applicable, demonstrations of proficiency controlled by qualification standards, and oral examinations or interview, if needed, to prepare for the comprehensive biennial requalification.

\section{Radiological Control Technician Supervisors}

An RCT supervisor should have qualified as an RCT or should have a minimum of a bachelor's degree or the equivalent experience in radiological protection. The RCT supervisor should be an experienced professional in radiological control and should be familiar with the design features and operations of the facility or site where work is being performed. RCT supervisors should have adequate knowledge of operations and sitespecific information to respond and direct others in emergency and abnormal situations.

\section{Subcontracted Radiological Control Technicians}

Subcontractor RCTs are individuals who are not NNSA/NSO employees or NNSA/NSO-contractor employees.

1. Subcontracted RCTs should have the same knowledge and qualifications required of RSPC and/or TO RCTs performing the same duties.

2. Subcontracted RCTs who work at NNSA/NSO facilities for extended periods (more than 6 months) should receive continuing training commensurate with their assigned duties. Completing an oral examination according to Article 642 is encouraged.

\section{PART 5 OTHER RADIOLOGICAL TRAINING}

\section{Work Planners}

Planners who develop detailed work plans involving or associated with radioactivity or radioactive materials should have Radiological Worker Training to the level required by the workers using the work plans. It is recommended that planners have RW-II training.

\section{Radiographers and RGD Operators}

1. Radiographers shall have training according to 10 CFR 34.43.

2. RGD Operators:

a. Open beam, open installation, or shielded devices as defined in ANSI N43.3 require $x$-ray safety training and RW-I training.

b. Cabinet $x$-ray systems, exempt shielded installations, unattended installations, or enclosed beam systems as defined in ANSI N43.2 and N43.3 require x-ray safety training and GERT. 


\section{Emergency Response Personnel}

Provisions should be in place to accommodate rapid site and radiological-area access by onsite and offsite emergency workers such as firefighters, medical personnel, and security personnel.

1. Emergency response personnel, from both onsite and offsite, may be required to work in radiological areas.

2. Emergency response personnel should receive Radiological Worker Training commensurate with the situations they are likely to encounter.

3. Such training should be based on the radiological worker standardized core course and site-specific training materials.

4. Training should make it clear that lifesaving has priority over radiological controls.

5. Records of this training should be maintained.

\section{Escorts}

When an escort is used in lieu of training according to Chapter 3, Part 3, "Entry and Exit Requirements," (Articles 331, 333, 334, 335, 336, and 365), the escort shall:

1. Have completed radiation safety training, examinations, and performance demonstrations required for entry into the area and performance of the work.

2. Ensure that all escorted individuals comply with the documented radiation protection program. 


\section{TABLE OF CONTENTS}

$\underline{\text { Article }}$

Page

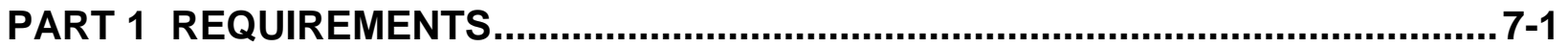

711 Purpose .................................................................................................... 7-1

712 Records Management Program ....................................................... 7-1

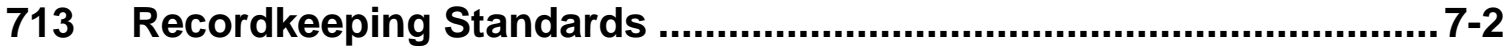

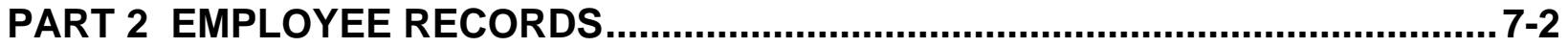

721 Employment History ........................................................................... 7-2

722 Personnel Radiological Records ...................................................... 7-2

723 Other Personnel Radiological Records .......................................... 7-4

725 Radiological Training and Qualification Records Requirements ..... 7-4

726 Radiological Training and Qualification Records .............................. 7-4

PART 4 RADIOLOGICAL CONTROL PROCEDURES .......................................... 7-5

741 Procedures and Radiological Work Permits ................................... 7-5

742 ALARA Program Records ........................................................... 7-6

PART 5 RADIOLOGICAL MONITORING AND SURVEYS ................................... 7-6

751 Requirements....................................................................................... 7-6

752 Radiation Surveys ............................................................................ 7-7

753 Airborne Radioactivity...................................................................... 7-7

754 Contamination Surveys................................................................. 7-7

755 Sealed Radioactive Sources ......................................................... 7-7

PART 6 INSTRUMENTATION AND CALIBRATION RECORDS............................ 7-8

761 Calibration and Operational Checks .......................................... 7-8

PART 8 RADIOLOGICAL REPORTING............................................................. 7-9

781 Reports to Individuals ................................................................... 7-9

782 Annual Radiation Report................................................................ 7-9

783 Other Reports................................................................................ 7-10 
THIS PAGE INTENTIONALLY LEFT BLANK 


\section{PART 1 REQUIREMENTS}

\section{Purpose}

Radiological control records shall be maintained as necessary to document compliance with the requirements of 10 CFR 835 . Records should be handled such that personal privacy is protected. Upon cessation of activities that could result in the occupational exposure of individuals, all required records shall be transferred to NNSA/NSO. Unless otherwise specified in this section, records shall be retained until final disposition is authorized by NNSA/NSO.

\section{Records Management Program}

1. A radiological records management program shall be established by each NNSA/NSO TO. This program shall ensure that auditable records and reports are controlled through the stages of creation, distribution, use, arrangement, storage, retrieval, media conversion (if applicable), and disposition. The records management program shall include items a through $\mathrm{k}$ below, and should include the remaining items:
a. Individual occupational doses
b. Internal and external dosimetry policies and procedures (including technical basis documents)
c. Personnel training records
d. ALARA records (The records generated for the NTS Contractor's SWAC shall be maintained by the RSPC)
e. Radiological instrumentation test, maintenance, and calibration records.
f. Radiological surveys (including material release surveys)
g. Area monitoring dosimetry results
h. RWPs
i. Records of sealed radioactive source accountability and control
j. Records for release of material to controlled areas
k. Records that document the results of internal audits, assessments, and other reviews of program content and implementation
I. Radiological control procedures
m. Radiological incident and occurrence reports (and critique reports, if applicable)

2. Where radiological services (for example, dosimetry and laboratory analyses) are purchased, there should be a clear agreement regarding records responsibility during performance of the service. Records of results should reside in the custody of the originating contract organization. 


\section{Recordkeeping Standards}

1. Radiological control records should include the following:
a. Identification of the facility, specific location, general function, and process
b. Signature or other identifying code of the preparer and date
c. Legible entries in ink
d. Corrections identified by a single lineout, initialed, and dated
e. Supervisory signature to ensure review and proper completion of forms

2. Radiological control records shall not include the following:
a. Opaque substances for corrections
b. Shorthand or other non-standardized terms

3. The quantities used in the records required by this part shall be clearly indicated in special units of curie, rad, roentgen, or rem, including multiples and subdivisions of these units, or other conventional units, such as, dpm, $\mathrm{dpm} / 100 \mathrm{~cm}^{2}$, or mass units. The SI units, becquerel (Bq), gray (Gy), and sievert (Sv), may only be provided parenthetically for reference with scientific standards, except when required by regulations (e.g., 49 CFR).

\section{PART 2 EMPLOYEE RECORDS}

\section{Employment History}

Documentation of all occupational doses received during the current year, except for doses resulting from planned special exposures and emergency exposures, shall be obtained to demonstrate compliance with occupational dose limits for general employees. If complete records documenting previous occupational dose during the year cannot be obtained, a written estimate signed by the individual may be accepted to demonstrate compliance.

Reasonable efforts shall be made to obtain complete records of previous years' occupational internal and external doses for radiological workers whose occupational dose is monitored according to 10 CFR 835.402.

\section{Personnel Radiological Records}

1. Records of doses received by all individuals for whom individual monitoring was performed shall be recorded in the individual's occupational dose record and shall be maintained by the RSPC. These records shall be sufficient to evaluate compliance with applicable dose limits and monitoring and reporting requirements. 
2. Radiation dose records shall contain information sufficient to identify each person, including social security number, employee number, or other unique identifier.

3. Routine and special records (such as evaluations resulting from anomalous dose results, from lost or damaged dosimeters, or for unmonitored workers or evaluation of non-uniform radiation dose) related to radiation doses shall be retained for each person monitored. Procedures, data, and supporting information needed to reconfirm a person's dose at a later date shall be maintained.

4. The records shall include the following quantities for external dose received during the year:
a. The effective dose from external sources of radiation (equivalent dose to the whole body may be used as effective dose for external exposure)
b. The equivalent dose to the lens of the eye
c. The equivalent dose to the skin
d. The equivalent dose to the extremities

5. Internal dose records shall include the following information for internal dose resulting from intakes received during the year:
a. CED
b. Committed equivalent dose to any organ or tissue of concern
c. Identity of radionuclides

6. The TED received by each individual monitored in accordance with Article 511.1 or 521.1 shall be maintained for each year the individual is monitored.

7. Records of the summation of external equivalent dose to the whole body and committed equivalent dose to any organ receiving a reportable dose shall be maintained for the individual receiving such dose.

8. Include the dose equivalent to the embryo/fetus of a declared pregnant worker.

9. Individual dose records shall include the cumulative TED.

10. Records of authorization to exceed Administrative Control Levels should be retained.

11. Emergency doses shall be accounted for separately, but should be maintained with the individual's occupational dose records.

12. Recording the non-uniform, equivalent dose to the skin is not required if the dose is less than 2 percent of the limit specified for the skin in Table 2-1. 
13. Recording of internal dose (CED or committed equivalent dose) is not required for any monitoring result estimated to correspond to an individual receiving less than 0.01 rem CED. The bioassay or air monitoring result used to make the estimate shall be maintained in accordance with § 835.703(b) and the unrecorded internal dose estimated for any individual in a year shall not exceed the applicable monitoring threshold in Article 521.1.

\section{Other Personnel Radiological Records}

1. The records of radiological incidents and occurrences involving personnel dose shall be retained.

2. Written declaration of pregnancy, including the estimated date of conception, and revocations of declaration of pregnancy shall be maintained.

\section{Radiological Training and Qualification Records Requirements}

1. The RSPC is specifically required to:

a. Maintain the worker training tracking system for TOs.

b. Provide reports of worker training to TOs upon request.

c. Maintain a copy of worker training records, training materials, and revisions.

2. TOs that perform radiological training are required to maintain a copy of worker training records, training materials, and revisions.

\section{Radiological Training and Qualification Records}

Any TO providing radiological training shall adhere to the requirements of this Article.

1. Records of training and qualification in radiological control shall be maintained to demonstrate that a person received appropriate information to perform the work assignment in a safe manner. Qualification standard records should be retained for on-the-job and practical factor training as well as for formal classroom training.

2. Records of training and qualification should be readily available to supervision of involved personnel to aid in making work assignments.

3. Personnel training records should include the following information:
a. Course title
b. Attendance sheets with instructor's name
c. Employee's name, identification number, and signature
d. Date of training 
e. Identification of the examination or evaluation form, including sufficient data to identify which test each person completed

f. Verification document or record confirming satisfaction of the training requirement

g. Documentation related to exceptions for training requirements and qualification extensions

h. Examinations and acknowledgments of training with the date and signature of the person trained

i. Special instructions to females, their supervisors, and coworkers concerning prenatal radiation dose, acknowledged by the worker's signature

4. Records shall be retained for the following types of training:
a. GERT
b. RW-I and RW-II training
c. RCT training
d. Emergency response personnel training
e. Periodic retraining
f. Instructor training
g. Qualifications for special tests or operations

5. The following instructional materials shall be maintained:
a. Instructor's manuals, course content, or lesson plans containing topical outlines
b. Job-specific training documents, such as instrument use, radiological procedures, RWP special training requirements, pre-job briefings, and mock-up training

6. Records shall be maintained as necessary to demonstrate that individuals who are responsible for the development and implementation of measures necessary to ensure compliance with 10 CFR 835 have the appropriate education, training, and skills to execute these responsibilities.

\section{PART 4 RADIOLOGICAL CONTROL PROCEDURES}

\section{Procedures and Radiological Work Permits}

Records of the radiological control program should consist of procedures, RWPs, and supporting data. The records should be maintained in a manner that will allow correlation with the corresponding support information. For example, procedures for performing radiation surveys should be identifiable with the survey results. 


\section{ALARA Program Records}

1. Records of actions taken to maintain occupational exposures ALARA shall be maintained [see 835-701(a)]. These records shall include facility design and control measures [see 835.704(b)] and should include the following:
a. ALARA plans and goals
b. The minutes of ALARA committees and other committees where radiological safety issues are formally discussed
c. Records of installation and removal of engineered controls

\section{Assessment Records}

1. Records of assessments developed for radiological control functions shall be retained. Assessment records should include:
a. Checklists
b. Methods
c. Results

\section{PART 5 RADIOLOGICAL MONITORING AND SURVEYS}

\section{Requirements}

1. Radiological control programs require the performance of radiation, airborne radioactivity, and contamination surveys to determine existing conditions in a given location. Results of radiological surveys should be recorded and include the following information:
a. Date, time, and purpose of the survey
b. General and specific location of the survey
c. Name and signature of the surveyor
d. Information needed to interpret the survey results
e. Reference to a specific RWP if the survey is performed to support the permit

2. Records shall be maintained to document the following information:
a. Results of monitoring and surveys for radiation and radioactive materials
b. Results of monitoring and calculations used to determine individual occupational exposures
c. Results of surveys for release of materials from radiological areas
d. Results of sealed source leak tests and inventories
e. Results of surveys of radioactive material packages received from transportation
f. Changes in monitoring equipment, techniques, and procedures 


\section{Radiation Surveys}

In addition to the elements provided in Article 751, records of radiation surveys shall include, at a minimum, the following information:

1. Instrument model and serial number

2. Measurement results of area dose rates

\section{Airborne Radioactivity}

In addition to the elements provided in Article 751, airborne radioactivity monitoring documentation shall include, at a minimum, the following information:

1. Model and serial numbers of the sampler and laboratory counting instrument when available or unique identifier of each sampler and instrument

2. Location of fixed air samplers

3. Location of portable air samplers used for a survey

4. Measured air concentrations

5. Supporting parameters, including collection efficiency, flow rate, duration of sampling, correction factors, and filter medium

\section{Contamination Surveys}

In addition to the elements required by Article 751, contamination survey records shall include, at a minimum, the following information:

1. Model and serial number of counting equipment

2. Contamination levels (using appropriate units) and appropriate supporting parameters such as counting efficiency, counting time, correction factors, type of radiation, and whether the contamination was total or removable

\section{Sealed Radioactive Sources}

Records shall be maintained as necessary to demonstrate compliance with Articles 431.01 and 431.2 a-e.

1. Records of sealed radioactive source leak tests should include, at a minimum, the following information:

a. Model and serial number of counting equipment

b. Contamination levels (using appropriate units) and appropriate supporting parameters including counting efficiency, counting time, correction factors, and type of radiation

c. Corrective actions for leaking sources 
2. Records of sealed radioactive source inventories shall include, at a minimum, the following information:

a. The physical location of each accountable sealed radioactive source

b. Verification of the presence and adequacy of associated postings and labels

c. Verification of the adequacy of storage locations, containers, and devices

\section{PART 6 INSTRUMENTATION AND CALIBRATION RECORDS}

\section{Calibration and Operational Checks}

1. Calibration records for fixed, portable, and laboratory radiation-measuring equipment and individual monitoring devices shall be maintained and include frequencies, method, dates, personnel, training, and traceability of calibration sources to NIST (see Article 562.1) or other acceptable standards.

2. Calibration and maintenance records shall be maintained for instruments and equipment used for monitoring. Calibration and maintenance records should be maintained for the following equipment:
a. Portable survey instruments
b. Bioassay measurement equipment
c. Laboratory, counting room, and fixed radiation measuring equipment
d. Process and effluent monitors and sampling equipment
e. Radiation area monitors
f. Portal monitors and other personnel contamination monitors
g. Pocket and electronic dosimeters
h. Air sampling equipment
i. Tool and waste monitoring equipment
j. $\quad$ PC and equipment monitors

3. Documentation of instrument operational checks shall be maintained for a period of not less than the calibration period of the instrument.

4. Maintenance histories, corrective actions taken, and calibration results for each instrument shall be created and retained. 


\section{PART 8 RADIOLOGICAL REPORTING}

\section{Reports to Individuals}

1. Annual and Current Dosimetry Reports

a. Personnel who are monitored by the personnel dosimetry program according to 10 CFR 835.402 shall be provided an annual report of their dose including the information required by 10 CFR 835.702(c).

b. Detailed information concerning an individual's exposure shall be made available to that individual, upon request, consistent with the Privacy Act of 1974 , which contains requirements to protect the privacy of individual records.

\section{Termination Dosimetry Reports}

a. Upon the request from an individual terminating employment, records of exposure shall be provided to that individual as soon as the data are available, but not later than 90 days after termination.

b. A written estimate of the radiation dose received by that employee based on available information shall be provided at the time of termination, if requested.

3. Reports of individual doses shall include the site or facility name, the individual's name, and social security or employee number or other unique identifiers.

4. Reports of individual exposure to radiation or radioactive material required under DOE M 231.1-2, "Occurrence Reporting and Processing of Operations Information," shall be submitted to DOE or NNSA/NSO according to departmental occurrence reporting requirements. Copies of the individual dose information contained in these reports shall be provided to the affected individual at a time not later than transmittal of the report to DOE or NNSA/NSO.

\section{Annual Radiation Report}

1. The RSPC annual Radiation Exposure Management System report includes the RSPC, NNSA/NSO, and all TO employees whose employing organization(s) do not submit an annual report to Science Applications International Corporation (SAIC). The RSPC shall submit the report for radiological workers and members of the public to SAIC at Oak Ridge, Tennessee, by March 31 of the following year. The RSPC shall also provide the annual Radiation Exposure Management System report directly to those TOs who submit it directly to SAIC.

2. This report includes internal and external radiation dose results for monitored NNSA/NSO and TO employees and for monitored members of the public. 


\section{Other Reports}

1. The RSPC shall:

a. Issue a dose report on a quarterly basis to each TO that includes monitored personnel for that organization and recorded doses for each individual.

b. Issue a quarterly, blind audit, dosimeter report to each TO.

c. Provide a nonreturned dosimeter report listing the names of each individual who did not return their dosimeter during the previous quarter. The report should be distributed within 15 days of the end of the dosimeter exchange period.

2. TOs should:

a. Review the quarterly dose report, verify those persons listed under the pertinent organization are correct, verify the exposures are as expected, investigate any anomalies, and report discrepancies to the RSPC.

b. Retrieve nonreturned dosimeters and return to the RSPC for processing.

c. Provide administrative dose assignments to the RSPC when required. 


\section{A}

Abnormal Situation: An unplanned event or condition that adversely affects, potentially affects, or indicates degradation in the safety, security, environmental, or health protection performance or operation of a facility.

Absorbed Dose (D): The average energy imparted by ionizing radiation to the matter in a volume element divided by the mass of the matter in the volume. The absorbed dose is expressed in units of rad (or Gy) (1 rad $=0.01 \mathrm{~Gy}$ ).

Accountable Sealed Radioactive Source: A sealed radioactive source having a halflife equal to or greater than 30 days and an isotopic activity equal to or greater than the corresponding value provided in Appendix E of 10 CFR 835.

Activity Median Aerodynamic Diameter (AMAD): A particle size in an aerosol where 50 percent of the activity in the aerosol is associated with particles of aerodynamic diameter greater than the AMAD.

Activation: The process of producing a radioactive material by bombardment with neutrons, protons, or other nuclear particles.

Administrative Control Level: A numerical dose constraint established at a level below the occupational exposure limits provided in 10 CFR 835 to administratively control and help reduce individual and collective doses.

Airborne Radioactive Material or Airborne Radioactivity: Radioactive material dispersed in the air in the form of dusts, fumes, particulates, mists, vapors, or gases.

Airborne Radioactivity Area: Any area, accessible to individuals, where:

(i) The concentration of airborne radioactivity, above natural background, exceeds or is likely to exceed the DAC values listed in Appendix A or Appendix C of 10 CFR 835; or

(ii) An individual present in the area without respiratory protection could receive an intake exceeding 12 DAC-hours in a week.

As Low As Reasonably Achievable (ALARA): The approach to radiation protection that manages and controls exposures (both individual and collective) to the work force and to the general public to as low as is reasonable, taking into account social, technical, economic, practical, and public policy considerations. As used in 10 CFR 835, ALARA is not a dose limit but a process that has the objective of attaining doses as far below the applicable limits of 10 CFR 835 as is reasonably achievable. 
Annual Limit on Intake (ALI): The derived limit for the amount of radioactive material taken into the body of an adult worker by inhalation or ingestion in a year. ALI is the smaller value of intake of a given radionuclide in a year by the reference man (International Commission on Radiation Protection ICRP Publication 23, Reference Man: Anatomical, Physiological and Metabolic Characteristics) that would result in a committed effective dose 5 rem $(0.05$ sieverts [Sv]) or a committed equivalent dose of $50 \mathrm{rem}(0.5 \mathrm{~Sv})$ to any individual organ or tissue. ALI values for intake by ingestion and inhalation of selected radionuclides are based on ICRP Publication 68, Dose Coefficients for Intakes of Radionuclides by Workers, published July 1994 (ISBN 008 042651 4). This document is available from Elsevier Science Inc., Tarrytown, New York.

ALARA Committee: A multidisciplined forum that reviews and advises management on improving progress toward minimizing radiation exposure and radiological releases. May be site-wide, to include representatives from all TOs at the NTS, or company- or user-specific.

Assessment: The evaluation or appraisal of a process, program, or activity to estimate its acceptability.

Authorized Limit: A limit on the concentration of residual radioactive material on the surfaces or within the property that has been derived consistent with DOE directives including the ALARA process requirements, given the anticipated use of property and has been authorized by DOE to permit the release of the property from DOE radiological control.

\section{$\boldsymbol{B}$}

Background: Radiation from the following sources:

1. Naturally occurring radioactive materials that have not been technologically enhanced

2. Cosmic sources

3. Global fallout as it exists in the environment (such as from the testing of nuclear explosive devices)

4. Radon and its progeny in concentrations or levels existing in buildings or the environment which have not been elevated as a result of current or previous activities

5. Consumer products containing nominal amounts of radioactive material or producing nominal amounts of radiation 
Becquerel (Bq): The SI unit for activity of radioactive material. One $\mathrm{Bq}$ is that quantity of radioactive material in which one atom is transformed per second or undergoes one disintegration per second.

Bioassay: The determination of the kinds, quantities, or concentrations, and, in some cases, locations of radioactive material in the human body, whether by direct measurement or by analysis and evaluation of radioactive materials excreted or removed from the human body.

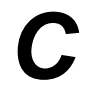

Calibration: The means to adjust and/or determine either:

1. The response or reading of an instrument relative to a standard (e.g., primary, secondary, or tertiary) or to a series of conventionally true values; or

2. The strength of a radiation source relative to a standard (e.g., primary, secondary, or tertiary) or conventionally true value.

Committed Effective Dose $\left(E_{50}\right)$ : The sum of the committed equivalent dose to various tissues or organs in the body $\left(\mathrm{H}_{T, 50}\right)$, each multiplied by the appropriate tissue

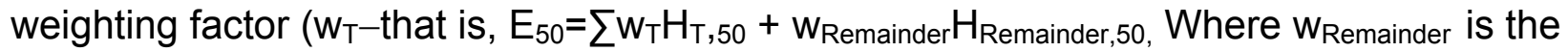
tissue weighting factor assigned to the remainder organs and tissues and $\mathrm{H}_{\text {Remainder,50 }}$ is the committed equivalent dose to the remainder organs and tissues. Committed effective dose is expressed in units of rem (or Sv).

Committed Equivalent Dose $\left(H_{T, 50}\right)$ : The equivalent dose calculated to be received by a tissue or organ over a 50-year period after the intake of a radionuclide into the body. It does not include contributions from radiation sources external to the body. Committed equivalent dose is expressed in units of rem (or Sv).

Company-Issued Clothing: The clothing provided by the company, such as work coveralls and shoes. For radiological control purposes, company-issued clothing shall be considered the same as personal clothing. See "Modesty Garments."

Containment Device: A barrier such as a glove bag, glove box, or tent for inhibiting the release of radioactive material from a specific location.

Contamination Area: Any area, accessible to individuals, where removable surface contamination levels exceed or are likely to exceed the removable surface contamination values specified in Appendix D of 10 CFR 835 [and restated in Chapter 2, Table 2-2, of this manual], but do not exceed 100 times those values. 
Continuing Training: Training scheduled over a specified time such as over a two-year period for the purpose of maintaining and improving technical knowledge and skills.

Continuous Air Monitor (CAM): An instrument that continuously samples and measures the levels of airborne radioactive materials on a "real-time" basis and has alarm capabilities at preset levels.

Controlled Area: Any area to which access is managed by or for DOE or NNSA/NSO to protect individuals from exposure to radiation and/or radioactive material.

Critical Mass: The smallest mass of fissionable material that will support a self-sustaining chain reaction under specified conditions.

Critique: Meetings of personnel involved in or knowledgeable about an event (either a success or an abnormal event) to document a chronological list of the facts.

Cumulative Total Effective Dose: The sum of all total effective dose values recorded for an individual plus, for occupational exposures received before the implementation date of this amendment, the cumulative total effective dose equivalent (as defined in 10 CFR 835 amendment dated November 4, 1998) values recorded for an individual, where available, for each year occupational dose was received, beginning January 1 , 1989.

\section{D}

Declared Pregnant Worker: A woman who has voluntarily declared to her employer, in writing, her pregnancy for the purpose of being subject to the occupational exposure limits to the embryo/fetus as provided in 10 CFR 835.206. This declaration may be revoked, in writing, at any time by the declared pregnant worker.

Decontamination: The process of removing radioactive contamination and materials from personnel, equipment, or areas.

Derived Air Concentration (DAC): For the radionuclides listed in Appendix A of 10 CFR 835, the airborne concentration that equals the ALI divided by the volume of air breathed by an average worker for a working year of 2,000 hours (assuming a breathing volume of 2,400 $\mathrm{m}^{3}$ ). For the radionuclides listed in Appendix C of 10 CFR 835, the air immersion DACs were calculated for a continuous, nonshielded exposure via immersion in a semi-infinite cloud of radioactive material.

Derived Air Concentration-hour (DAC-hour): The product of the concentration of radioactive material in the air (expressed as a fraction or multiple of the DAC for each radionuclide) and the time of exposure to that radionuclide, in hours. 
Deterministic Effects: The effects due to radiation exposure for which the severity varies with the dose and for which a threshold normally exists (e.g., radiation-induced opacities within the lens of the eye).

Disintegrations per Minute ( $\mathbf{d p m})$ : The rate of emission by radioactive material as determined by correcting the counts per minute observed by an appropriate detector for background, efficiency, and geometric factors associated with the instrumentation.

DOE: The United States Department of Energy.

DOE Activity: An activity taken for or by the DOE or NNSA/NSO in a DOE or NNSA/NSO operation or facility that has the potential to result in the occupational exposure of an individual to radiation or radioactive material. The activity may be, but is not limited to, design, construction, operation, or decommissioning. To the extent appropriate, the activity may involve a single DOE or NNSA/NSO facility or operation or a combination of facilities and operations, possibly including an entire site or multiple DOE or NNSA/NSO sites.

DOE Laboratory Accreditation Program (DOELAP): Accreditation program for personnel dosimetry under DOE O 5480.15.

Dose: The general term for absorbed dose, equivalent dose, effective dose, committed equivalent dose, committed effective dose, or total effective dose as defined in 10 CFR 835.

Dose Assessment: The process of determining radiological dose and uncertainty included in the dose estimate, through the use of exposure scenarios, bioassay results, monitoring data, source term information, and pathway analysis.

Effective Dose (E): The summation of the products of the equivalent dose received by specified tissues or organs of the body $\left(\mathrm{H}_{\mathrm{T}}\right)$ and the appropriate tissue weighting factor $\left(w_{T}\right)$-that is, $E=\Sigma w_{T} H_{T}$. It includes the dose from radiation sources internal and/or external to the body. For purposes of compliance with 10 CFR 835, equivalent dose to the whole body may be used as effective dose for external exposures. The effective dose is expressed in units of rem (or Sv).

Embryo/Fetus: The developing human organism from conception until birth. The same as an unborn child.

Engineered Controls: The practice of using components and systems to reduce airborne radioactivity and the spread of contamination by using piping, containments, ventilation, filtration, or shielding. 
Equivalent Dose $\left(\mathrm{H}_{\mathrm{T}}\right)$ : The product of average absorbed dose $\left(\mathrm{D}_{\mathrm{T}, \mathrm{R}}\right)$ in rad (or $\mathrm{Gy}$ ) in a tissue or organ $(T)$ and a radiation $(R)$ weighting factor $\left(w_{R}\right)$. For external dose, the equivalent dose to the whole body is assessed at a depth of $1 \mathrm{~cm}$ in tissue; the equivalent dose to the lens of the eye is assessed at a depth of $0.3 \mathrm{~cm}$ in tissue, and the equivalent dose to the extremity and skin is assessed at a depth of $0.007 \mathrm{~cm}$ in tissue. Equivalent dose is expressed in units of rem (or Sv).

External Dose or Exposure: That portion of the equivalent dose received from radiation sources outside the body (i.e., "external sources").

Extremity: The hands and arms below the elbow, or feet and legs below the knee.

Facility: For the purpose of this manual, a facility includes systems, buildings, utilities, and related activities whose use is directed to a common purpose at a single location. Examples include: accelerators, storage areas, test loops, nuclear reactors, radioactive waste disposal systems and burial grounds, testing laboratories, research laboratories, and accommodations for analytical examinations of components. A facility also includes: pipelines, ponds, impoundments, landfills, motor vehicles, rolling stock, and aircraft.

Fixed Contamination: Radioactive material that cannot be readily removed from surfaces by nondestructive means, such as casual contact, wiping, brushing, or laundering.

Frisk or Frisking: The process of monitoring personnel for contamination. Frisking can be performed with hand-held survey instruments, automated monitoring devices, or by an RCT.

\section{$\mathbf{G}$}

General Employee: An individual who is either a DOE or NNSA/NSO employee or DOE or NNSA/NSO-contractor employee, an employee of a subcontractor to a DOE or NNSA/NSO contractor, or an individual who performs work for or in conjunction with DOE or NNSA/NSO, or uses DOE or NNSA/NSO facilities.

Gestation Period: The time from conception to birth, approximately 9 months.

Gray (Gy): SI unit of absorbed dose. One Gy is equal to an absorbed dose of 1 joule per kilogram (100 rads). 


\section{H}

High-Efficiency Particulate Air (HEPA) Filter: The disposable, extended-pleat medium, dry-type filter with (1) a rigid casing enclosing the full depth of the pleats, (2) a minimum particle removal efficiency rate of 99.97 percent for thermally generated monodispersed di-octyl phthalate smoke particles with a diameter of 0.3 micrometer, and (3) a maximum pressure drop of 1.0-inch water gage when clean and operated at its rated airflow capacity.

High Contamination Area: Any area, accessible to individuals, where removable surface contamination levels exceed or are likely to exceed 100 times the surface contamination values specified in Appendix D of 10 CFR 835 and restated in Chapter 2, Table 2-2, of this manual.

High Radiation Area: Any area, accessible to individuals, in which radiation levels could result in an individual receiving an equivalent dose to the whole body in excess of 0.1 rem $(0.001 \mathrm{~Sv})$ in 1 hour at $30 \mathrm{~cm}$ from the radiation source or from any surface that the radiation penetrates.

Hyperthermia: Heat stress, comprising "heat exhaustion," "heat stroke," and in extreme cases coma and death; a significant possibility at the NTS especially while wearing $\mathrm{PC}$ in the summer months, if appropriate precautions are not taken.

Hypothermia: Cold stress, which may include frostbite or worse. Also a significant possibility at the NTS, especially during the winter months. PC alone is not to be considered adequate protection for the skin of personnel working in outdoor radiological locations during inclement weather at the NTS.

Individual: Any human being.

Internal Dose or Exposure: That portion of the equivalent dose received from radioactive material taken into the body (i.e., "internal sources").

Irradiator: Sealed radioactive material used to irradiate other materials that has the potential to create a radiation level exceeding 500 rad (5 Gy) in 1 hour at 1 meter. Although not addressed in this manual, acceptable radiological controls for irradiator use are specified in 10 CFR Part 20.1603. 
$L$

Low-Level Radioactive Waste: Waste that contains radioactivity and is not classified as high-level waste, transuranic waste, spent nuclear fuel, or byproduct material as defined in Section 11e(2) of the Atomic Energy Act, as amended. Test specimens of fissionable material irradiated only for research and development and not for producing power or plutonium may be classified as low-level waste provided the concentration of transuranic activity is less than $100 \mathrm{nCi} / \mathrm{g}$.

\section{$M$}

Member of the Public: An individual who is not a general employee. An individual is not a "member of the public" during any period in which the individual receives an occupational dose.

Minor: An individual less than 18 years of age.

Mixed Waste: Waste containing both radioactive and hazardous components as defined by the Atomic Energy Act and the Resource Conservation and Recovery Act, respectively.

Modesty Garments: Disposable paper or launderable cloth garments issued by the RSPC, and worn under PC for the purpose of protecting the modesty of individuals during (predominantly) outdoor work and temporary undress at Hot Line facilities, which are typically available at the NTS during post-event related data acquisition work. Not to be considered "company-issued" garments for the purposes of this manual. May be issued as "winter-weight" garments to help shield personnel from the effects of hypothermia during inclement weather conditions.

Monitoring: The measurement of radiation levels, airborne radioactivity concentrations, radioactive contamination levels, quantities of radioactive material, or individual doses and the use of the results of these measurements to evaluate radiological hazards or potential and actual doses resulting from exposures to ionizing radiation. 


\section{$N$}

Nuclear Criticality: A self-sustaining chain reaction, i.e., the state in which the effective neutron multiplication constant of fissionable material equals or exceeds unity.

NTS RadCon Managers' Council: A chartered committee of the Radiological Control Program Managers of the respective NTS TOs, whose purpose is to discuss issues and make decisions relevant to radiological control at the NTS.

\section{0}

Occupational Dose: An individual's ionizing radiation dose (external and internal) as a result of that individual's work assignment. Occupational dose does not include doses received as a medical patient or doses resulting from background radiation or participation as a subject in medical research programs.

\section{$\boldsymbol{P}$}

Person: Any individual, corporation, partnership, firm, association, trust, estate, public or private institution, group, government agency, any state or political subdivision of, or any political entity within a state, any foreign government or nation or other entity, and any legal successor, representative, agent or agency of the foregoing, provided that person does not include the DOE, NNSA/NSO, or the NRC.

Personnel Dosimetry: Devices designed to be worn by a single person for the assessment of dose equivalent such as film badges, thermoluminescent dosimeters, and pocket ionization chambers.

Personnel Monitoring: Systematic and periodic estimates of radiation dose received by personnel during working hours. Also, monitoring personnel, their excretions, skin, or any part of their clothing to determine the amount of radioactivity present.

Personal Protective Equipment (PPE): Equipment such as respirators, face shields, and safety glasses used to protect workers from excessive exposure to radioactive or hazardous materials.

Planned Special Exposure: Preplanned, infrequent exposure to radiation, separate from, and in addition to, the annual dose limits.

Prenatal Radiation Exposure: Exposing an embryo/fetus to radiation. 
Primary Dosimeter: A dosimeter worn on the body used to obtain the formal record of whole-body radiation dose.

Protective Clothing (PC): Clothing provided to personnel to minimize the potential for skin, personal, and company-issued clothing contamination. Also referred to as "anticontamination clothing" and "anti-C."

Public: Any individual or group of individuals who are not occupationally exposed to radiation or radioactive material. An individual is not a "member of the public" during any period in which the individual receives an occupational dose (exposure).

\section{$Q$}

Qualification Standard: The explicit performance requirements for minimum proficiency in technical, academic, and site-specific knowledge and practical skills used in determining satisfactory completion of training programs. The qualification standard is used to qualify RCTs at DOE facilities.

\section{$\boldsymbol{R}$}

Rad: Unit of absorbed dose. One rad is equal to an absorbed dose of 100 ergs per gram or 0.01 joules per kilogram (0.01 Gy).

Radiation (Ionizing Radiation): Alpha particles, beta particles, gamma rays, x-rays, neutrons, high-speed electrons, high-speed protons, and other particles capable of producing ions. Radiation, as used in this manual and 10 CFR 835, does not include non-ionizing radiation such as radio waves and microwaves or visible, infrared, or ultraviolet light.

Radiation Area: Any area, accessible to individuals, in which radiation levels could result in an individual receiving an equivalent dose to the whole body in excess of $0.005 \mathrm{rem}(0.05 \mathrm{mSv})$ in 1 hour at $30 \mathrm{~cm}$ from the source or from any surface that the radiation penetrates.

Radiation Weighting Factor $\left(w_{R}\right)$ : The modifying factor used to calculate the equivalent dose from the average tissue or organ absorbed dose; the absorbed dose (expressed in rad or gray) is multiplied by the appropriate radiation weighting factor.

The radiation weighting factors to be used for determining equivalent dose in rem are listed in the following table: 
RADIATION WEIGHTING FACTORS ${ }^{1}, \mathrm{w}_{\mathrm{R}}$

\begin{tabular}{|l|c|}
\hline \multicolumn{1}{|c|}{ Type and Energy Range } & Radiation Weighting Factor \\
\hline Photons, electrons, and muons, all energies & 1 \\
\hline Neutrons, energy $<10 \mathrm{keV}^{2,3}$ & 10 \\
\hline Neutrons, energy $10 \mathrm{keV}$ to $100 \mathrm{keV}^{2,3}$ & 20 \\
\hline Neutrons, energy $>100 \mathrm{keV}$ to $2 \mathrm{MeV}^{2,3}$ & 10 \\
\hline Neutrons, energy $>2 \mathrm{MeV}$ to $20 \mathrm{MeV}^{2,3}$ & 5 \\
\hline Neutrons, energy $>20 \mathrm{MeV} 2,3$ & 5 \\
\hline Protons, other than recoil protons, energy > 2MeV & 20 \\
\hline Alpha particles, fission fragments, heavy nuclei & 5 \\
\hline
\end{tabular}

1. All values relate to the radiation incident on the body or, for internal sources, emitted from the source.

2. When spectral data are insufficient to identify the energy of the neutrons, a radiation weighting factor of 20 shall be used.

3. When spectral data are sufficient to identify the energy for the neutrons, the following equations may be used to determine a neutron radiation weighting factor value:

$$
W_{R}=5+17 \exp \left[\frac{\left.-\left(1 n\left(2 E_{n}\right)\right)^{2}\right]}{6}\right] \text { Where } E_{n} \text { is the neutron energy in MeV. }
$$

Radiation Protection Program (RPP): The documented program including, but not limited to, the plans, schedules, and other measures developed and implemented to achieve and ensure compliance with 10 CFR 835 and to apply the ALARA process to occupational exposure.

Radioactive Material: For the purposes of this manual, radioactive material includes any material, equipment, or system component determined to be contaminated or suspected of being contaminated. Radioactive material also includes activated material, sealed and unsealed sources, and material that emits radiation. 
Radioactive Material Area (RMA): Any area within a Controlled Area, accessible to individuals, in which items or containers of radioactive material exist and the total activity of radioactive material exceeds the applicable values provided in Appendix E of 10 CFR 835.

Radioactive Material Transportation: The movement of radioactive material by aircraft, rail, vessel, or highway vehicle when such movement is subject to DOT regulations or DOE orders that govern such movements. Radioactive material transportation does not include preparation of material or packagings for transportation, monitoring required by 10 CFR 835, storage of material awaiting transportation, or application of markings and labels required for transportation.

Radioactive Waste: Solid, liquid, or gaseous material that contains radionuclides regulated under the Atomic Energy Act, as amended, and is of negligible economic value considering the cost of recovery.

Radioactivity: A natural and spontaneous process by which the unstable atoms of an element emit or radiate excess energy from their nuclei and, thus, change (or decay) to atoms of a different element or to a lower energy state of the same element.

Radiography: Examination of the structure of materials by nondestructive methods, using a radioactive source or a radiation-generating device.

Radiological Area: Any area within a Controlled Area defined in this glossary as a Radiation Area, High Radiation Area, Very High Radiation Area, Contamination Area, High Contamination Area, or Airborne Radioactivity Area.

Radiological Control Hold Point: A cautionary step in a technical work document (e.g., procedure or RWP) requiring the Radiological Control Organization to perform some action or verification. The radiological control hold point requirements should be satisfactorily completed before the work is continued.

Radiological Control Technician (RCT): A radiological worker whose primary job assignment involves monitoring workplace radiological conditions, specifying protective measures, and providing assistance and guidance to other individuals in implementing radiological controls.

Radiological Engineer: An individual who is responsible for providing technical support and assistance to supervisors, planners, schedulers, principal investigators, and design engineers to reduce occupational doses and the spread of radioactive materials.

Radiological Label: A label on an item that indicates the presence of radiation or radioactive materials.

Radiological Posting: A sign, marking, or label that indicates the presence or potential presence of radiation or radioactive materials. 
Radiological Safety Prime Contractor (RSPC): The contractor assigned Maintenance and Operations responsibilities at the NTS by NNSA/NSO.

Radiological Work: Any work that requires handling radioactive material or requires access to Radiation Areas, High Radiation Areas, Contamination Areas, High Contamination Areas, Radioactive Material Areas, or Airborne Radioactivity Areas.

Radiological Work Permit (RWP): An authorization to conduct work involving exposure to radiation or radioactive materials that identifies radiological conditions, establishes worker protection and monitoring requirements, and contains specific approvals.

Radiological Worker: A general employee whose job assignment involves operation of radiation-generating devices or working with radioactive materials, or who is likely to be routinely occupationally exposed above 0.1 rem ( 0.001 sievert) per year total effective dose.

RAMATROL: Radioactive Materials Control Building, operated in Mercury by the RSPC.

Real-Time Air Monitoring: Measurement of the concentrations or quantities of airborne radioactive materials on a continuous basis.

Release to Uncontrolled Areas: Releasing material from administrative control after confirming that the residual radioactive material meets the guidelines in DOE 05400.5 and Table 4-2 of this manual.

Rem: Unit of dose equivalent. Dose equivalent in rem is numerically equal to the absorbed dose in rad multiplied by a quality factor, distribution factor, and any other necessary modifying factor (1 rem $=0.01 \mathrm{~Sv}$ ).

Removable Contamination: Radioactive material that can be removed from surfaces by nondestructive means, such as casual contact, wiping, brushing, or washing.

Representative: As applied to the sampling of radioactive material, means sampling in such a manner that the sample closely approximates both the amount of activity and the physical and chemical properties of material (e.g., particle size and solubility in case of air sampling of the aerosol to which workers may be exposed).

Respiratory Protective Device: An apparatus, such as a respirator, worn by an individual for the purpose of reducing the individual's intake of airborne radioactive or hazardous materials. 
Sealed Radioactive Source: A radioactive source manufactured, obtained, or retained for the purpose of using the emitted radiation. The sealed radioactive source consists of a known or estimated quantity of radioactive material contained within a sealed capsule, sealed between layer(s) of nonradioactive material, or firmly fixed to a nonradioactive surface by electroplating or other means intended to prevent leakage or escape of the radioactive material. Sealed radioactive sources do not include reactor fuel elements, nuclear explosive devices, or radioisotope thermoelectric generators.

Senior Site Executive: The person at an NNSA/NSO contractor-operated facility or site who has final onsite corporate authority and is often called President, General Manager, Resident Manager, Site Manager, or Director.

Sievert (Sv): SI unit of any of the quantities expressed as dose equivalent. The dose equivalent in sieverts is equal to the absorbed dose in grays multiplied by the quality factor (1 Sv = 100 rems).

Site: An area managed by NNSA/NSO where access can be limited for any reason. The site boundary encompasses Controlled Areas.

Source Leak (Integrity) Test: A test to determine if a sealed radioactive source is leaking radioactive material.

Special Tritium Compound: Any compound, except for $\mathrm{H}_{2} \mathrm{O}$, that contains tritium, either intentionally (e.g., by synthesis) or inadvertently (e.g., by contamination mechanisms).

Standard Radiation Symbols (Trefoil): Symbols designed and proportioned as illustrated according to ANSI N2.1 for radiation symbols and ANSI N12.1 for fissile material.

Step-Off Pad: The transition area between contaminated and noncontaminated areas that is used to allow exit of personnel and removal of equipment.

Stochastic Effects: Malignant and hereditary diseases for which the probability of an effect occurring, rather than its severity, is regarded as a function of dose, without a threshold for radiation protection purposes.

Survey: Evaluating the radiological conditions and potential hazards incident to the production, use, transfer, release, disposal, or presence of radioactive material or other sources of radiation. When appropriate, such an evaluation includes a physical survey of the location of radioactive material and measurements or calculations of levels of radiation, or concentrations or quantities of radioactive material present. 
$T$

Technical Work Document: A formally approved document that directs work, such as a procedure, work package, laboratory protocol, RWP, or job or research plan that also identifies radiological conditions, establishes worker protection and monitoring requirements, and contains specific approvals.

Tenant Organization: NTS user or contractor, e.g., any organization that maintains a permanent presence at the NTS.

Thermoluminescent Dosimeter: A radiation monitoring device used to record the radiological exposure of personnel or areas to certain types of radiation.

Tissue Weighting Factor $\left(\mathbf{w}_{\mathrm{T}}\right)$ : The fraction of the overall health risk, resulting from uniform, whole body irradiation, attributable to specific tissue $(T)$. The equivalent dose to tissue, $\left(\mathrm{H}_{\mathrm{T}}\right)$, is multiplied by the appropriate tissue weighting factor to obtain the effective dose $(E)$ contribution from that tissue. The tissue weighting factors are as follows:

TISSUE WEIGHTING FACTORS FOR VARIOUS ORGANS AND TISSUES

\begin{tabular}{|c|c|}
\hline ORGANS OR TISSUES, T & $\begin{array}{c}\text { TISSUE } \\
\text { WEIGHTING } \\
\text { FACTOR, } \mathbf{w}_{\mathrm{T}}\end{array}$ \\
\hline Gonads ........ & 0.20 \\
\hline Red bone marrow . & 0.12 \\
\hline Colon ..................... & 0.12 \\
\hline Lungs ............. & 0.12 \\
\hline Stomach . & 0.12 \\
\hline Bladder ............. & 0.05 \\
\hline Breast .................. & 0.05 \\
\hline Liver ......... & 0.05 \\
\hline Esophagus ... & 0.05 \\
\hline Thyroid & 0.05 \\
\hline Skin ....... & 0.01 \\
\hline Bone surfaces & 0.01 \\
\hline Remainder ${ }^{1}$.. & 0.05 \\
\hline Whole body ${ }^{2}$ & 1.00 \\
\hline
\end{tabular}


1. "Remainder" means the following additional tissues and organs and their masses, in grams, following parenthetically: adrenals (14), brain $(1,400)$, extrathoracic airways (15), small intestine (640), kidneys (310), muscle $(28,000)$, pancreas (100), spleen (180), thymus (20), and uterus (80). The equivalent dose to the remainder tissues $\left(\mathrm{H}_{\text {remainder }}\right)$, is normally calculated as the mass-weighted mean dose to the preceding ten organs and tissues. In those cases in which the most highly irradiated remainder tissue or organ receives the highest equivalent dose of all the organs, a weighting factor of 0.025 (half of remainder) is applied to that tissue or organ, and 0.025 (half of remainder) to the mass-weighted equivalent dose in the rest of the remainder tissues and organs to give the remainder equivalent dose.

2. For the case of uniform external irradiation of the whole body, a tissue weighting factor $\left(\mathrm{w}_{T}\right)$ equal to 1 may be used in determination of the effective dose.

Transuranic Waste: Without regard to source or form, waste that is contaminated with alpha-emitting transuranic radionuclides having half-lives greater than 20 years and concentrations greater than $100 \mathrm{nCi} / \mathrm{g}$ at the time of assay.

Total Effective Dose (TED): The sum of the effective dose equivalent (for external exposures) and the committed effective dose.

\section{$\boldsymbol{V}$}

Very High Radiation Area: Any area, accessible to individuals, in which radiation levels could result in an individual receiving an absorbed dose in excess of 500 rads ( $5 \mathrm{~Gy}$ ) in 1 hour at 1 meter from a radiation source or from any surface that the radiation penetrates.

\section{$W$}

Week: A period of seven consecutive days.

Whole Body: For the purposes of external exposure, head, trunk (including male gonads), arms above and including the elbow, or legs above and including the knee.

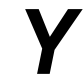

Year: The period of time beginning on or near January 1 and ending on or near December 31 of that same year used to determine compliance with the provisions of 10 CFR 835 and this manual. The starting and ending date of the year used to determine compliance may be changed provided that the change is made at the beginning of the year and that no day is omitted or duplicated in consecutive years. 
A

Abnormal Situations, Response To $346,633,644,646$, Glossary

Accelerator . $231,236,364,512$

Access

Control 235, 236, 334, 382, Appendix 3A, 553 Points 123, 231, 232, 236, 322, Appendix 3A, Glossary

Accident Dosimetry Appendix 1B, 515

Accountability 111, Appendix 1B, 431, 712 Activation Appendix 3A, Table 4-1, Glossary Administrative Control $311,316,322,342.364,382,551,554$ Level. 123 Poster, 211, 315, 722, Glossary

Air

Monitoring $223,363,522,551,555,722$

Sampling Overview, 555

Airborne Radioactivity $136,223,233,235,312,216$, Table 2-4, 316, $336,337,338,342,247,381,464,551,555,751,753$, Glossary

Control Levels. 223

Control Of 381

Monitoring Of Appendix 1B, 551, 555

Airborne Radioactivity Areas ......... 123 Poster, 223, 235, Table 2-4, 316, 322, 325, 335, 336, 337, 338, 342, Table 3B-1 Notes, Chapter 4 Part 1, 411, 413, 421, 554, Table 6-1, 632, 633, Glossary

ALARA Overview, 111, 128, 138, 157, 311, 312, 316, 381, 382, $611,712,742$, Glossary

Committee Appendix 1C, 138, 312, Glossary

Preplanning 551

Program Appendix 1B, Appendix 1C

Records 712,742 
Alarm. 346, Appendix 3A, Appendix 3C, 513, 515, 553, 555, 562, 633

Alarming or Faulty Radiological Control Equipment 123 Poster

Alpha. Table 2-2, Table 2-2 Notes, Appendix 3C, Table 4-2, Table 4-2 Notes, $461,541,555$

Area Monitoring 334

Dosimeter 514,553

Dosimetry 712

Program 514

Area Radiation Monitor. .Appendix 1B, 346, 553, 562

Arms Table 2-1, 325, 347, Appendix 3C

Assessment. ......134, Appendix 1A, Appendix 1B, Table 2-1 Notes, 312, 316, 512, 521, $522,541,551,555,712,722,743$, Glossary

Audit Appendix 1A, Appendix 1B, 134, 712, 783

\section{B}

Background ...........Table 1B, Table 2-1 Notes, 223, 231, 335, 338, 412, Table 4-2 Notes, 555, Glossary

Beta. Table 2-2 Notes, Appendix 2C, Appendix 3C, Table 4-2 Notes, 461, Chapter 5 Part 1, 512, 513, 541, 543

Bioassay. Overview, 521, 522, Glossary, 722

Breathing Zone 555

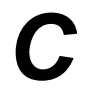

Calibrated $551,555,562$

Calibration 141, Appendix 1B, 551, 562, 563, 564, 761, Glossary

Facilities 564

Procedures 562

Record. $562,564,712,761$

Sources 761 
Committee. 138, Appendix 1C, 312

Company-Issued Clothing 325, Glossary

Container. 236, 335, 342, Chapter 4 Part 1, 412, Table 4-1, 413, 423, 431, 755

Containment $316,337,363,381$

Contaminated.... Overview, 123 Poster, 222, Table 2-2 Notes, 316, 335, 347, Appendix 3B, Table 3B Notes, Chapter 4 Part 1, 411, Table 4-1, 413, $421,511,554$

Area. 123 Posters, 221, 342

Materials 325

Personnel 512, Chapter 5 Part 4

Soil Areas Table 6-1

Systems 316

Tools. 123 Poster

Wounds 542

Contamination Overview, 123 Poster, 128, 221, 222, Table 2-2, Table 2-2 Notes, 231, 235, Table 2-4, 237, 312, 322, 325, 335, 337, 338, 342, 346, 347, 363, 381, Appendix 3B, Appendix 3C, 411, Table 4-1, 413, 421, 422, Table 4-2, Table 4-2 Notes, 423, 431, 461, 464, 522, 541, 551, 554, 633, 754

Area.. 123 Poster, 235, Table 2-4, 322, 325, 335, 336, 337, 338, 342, Appendix 3B, Chapter 4 Part 1, 411, 413, 421, 554, 611, Table 6-1, 633, Glossary

Control Appendix 1B, 221, 222, 361, 362, Appendix 3B, 551 Level. ..................222, Table 2-2 Notes, Table 2-4, 316, 324, 342, Appendix 3B, Table 3B-1, 412, 413, 421, Table 4-2 Notes, 423, 461, 541, 551, 754, 755 Limit. Appendix 3C, Table 4-1 
Monitor(Ing)

Reduction

Surveys

Continuing Training

Continuous Air Monitor (CAM)

Contractor $215,365,645,724,782$, Glossary
Appendix 1B, Appendix 3C, 335 312,321 $554,751,754$ 643, 645, Glossary 316, 555, Glossary

Control

Level. 123 Poster, 211, 222, 223, 722

Of Airborne 381

Of Work Activities 323

Points 554

Controlled Area $.214,221,231,232,236,237,331,336,381$, Chapter 4 Part 1 , 411, 412, 421, 422, 621, 622,Table 6-1, 633, 712, Glossary

Corrective Actions 755,761

Counseling ..... 213,542

Criteria For Posting Table 2-3, Table 2-4

Critical Mass 515, Glossary

Criticality. 515

Critique Appendix 1C, 712, Glossary

\section{D}

Declared Pregnant Worker. Table 2-1, 215, 511, 521, 722, Glossary Decontaminate 222, Appendix 3B, 461

Decontamination 123 Poster, 128, 141, 312, 318, 381, 413, 461, 541, 551, Glossary

Procedures 541 
Deficiencies 125

Derived Air Concentration (DAC) 223, 235, Table 2-4, 551, 555, Glossary

Design $111,128,142$, Appendix 1C, 311, 312, 316, 321, 364 , 365, 381, 382, Appendix 3B, 562, 644

Diagnostic Table 2-1 Notes

Disintegration (see dpm) .Table 2-2 Notes, 554, Glossary

Dpm (disintegrations per minute) ..Table 2-2, Table 2-2 Notes, Table 4-2, Table 4-2 Notes, 461, 541, 554

Disposable Surfaces 123 Poster

DOE Overview, 111,112, 128, Appendix 1A, Appendix 1B, 223, 231, 322, 361, 362, 363, 364, 381, 412, Table 4-2, 423, 632, 642, $643,661,662,663,664,712,781$, Glossary

DOELAP Overview, 512, 522, Glossary NNSA/NSO Overview, 111, 112, 116, 138, Chapter 1 Part 4, 141, 156, 157, Appendix 1A, 211, 213, 214, 215, 231, Table 2A-1 Notes, 312, 324, 345, 365, Appendix 3B, 431, Chapter 5 Part 1, 511, 512, 522, 551, 612, 613, $645,711,712,724,725,782$, Glossary

Dose 128, Appendix 1C, 211, 213, Table 2-1 Notes, 214, 215, 222, 223, 237, Appendix 2A, Table 2A-1, Table 2A-1 Notes, Table 2B-1 Notes, Table 2C-1, 312, 321, 334, 342, 345, 381, 382, Appendix 3A, Appendix 3B, 511, 512, 513, 514, 521, 541, 621, 712, 721, 722, 723, 725, 752, 781, 782, 783, Glossary

Assessment $512,521,541,722$, Glossary Equivalent 211, 213, Table 2-1 Notes, Table 2B-1 Notes, Table 2C-1, $381,511,521,722$, Glossary

Limits 128, Chapter 2 Part 1, 213, Table 2-1, Table 2-1 Notes, 214, 215, Table 2A-1, 381, 382, 721, 722, Glossary

Rate. 234, Table 2-3, 334, 342, 347, 464, 512, 551, 552, 553, 752

Record Table 2-1 Notes, 215, Table 2C-1, 722

Report 783 
Dosimeter.... 123 Poster, 334, 346, 363, Appendix 3B, Appendix 3C, Chapter 5 Part 1, 511, 512, 513, 514, 515, 553, 562, 783, Glossary

Dosimetry .... .Overview, 112, 123 Poster, 141, 321, 334, 335, 361, 363, 364, Chapter 5 Part 1, 511, 512, 514, 515, Chapter 5 Part 2, 521, 522, 542, 712, 781, Glossary

Program Appendix 1B, 511, 512, 521, 781

Elbow Table 2-1, Appendix 3C Electronic Dosimeter Appendix 3B, 513, 562

Embryo/Fetus Table 2-1, 215, 511, 521, 722, Glossary

Emergency .......... 112, 213, Appendix 2A, Table 2-1 Notes, 231, Table 2A-1, 312, 322, $423,542,644,656,721,725$

Exposure ....... Appendix 1B, 213, Appendix 2A, Table 2-1 Notes, Table 2A-1, 721 Procedures 312,365

Response $112,322,656,725$

Workers 656

Employee .... $125,138,156,213,323,522,611$, Chapter 6 Part 2, 645, Chapter 7 Part 2, 721, 722, 725, 781, 782

Records Chapter 7 Part 2

Entry 141, 221, 222, $237316,321,331,333,334,335,336,371,382$, Appendix 3A, 513, 552, 553, 554, 611, 632, 633, Table 6-1, 642, 657

Entry and Exit Requirements 222, 237, Chapter 3 Part 3, 657

Entry Requirements. 321, 336, 513, Table 6-1 Note

Environmental 318, Table 3B-1 Notes, 371, 551, 562

Equipment ........... 123 Poster, 311, 316, 325, 335, 338, 342, 371, 411, 412, Table 4-1, $413,421,431,461,464,515,531,551,554,555,633,655,751,752,754$ 
Escort, Escorted, Unescorted................... Table 2-1 Footnote, 331, 333, 334, 335, 336, $621,622,631$, Table 6-1, 632, 656, 657

Exit. $237,317,338,346,371,511,633,657$

Requirements 222, 237, Chapter 3 Part 3, 657

Exposure ...........111, 123, 123 Poster, 138, 142, 157, 213, Table 2-1, Table 2-1 Notes, 215, 223, 231, 235, Appendix 2A, Appendix 2C, Table 2C-1, 311, 312, 321, 342, 346, 363, 365, 381, 412, 461, Chapter 5 Part 1, 512, 515, 522, $551,552,555,564,611,622,661,662,663,711,721,722,751,781$

Control. $231,362,661$

External

Dose. $663,721,722$

Dosimetry Chapter 5 Part 1, 511, 512, 712 Exposure $213,362,661,662,722$

Extremity 213, Table 2-1, 312, 347, Glossary

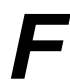

Facial Contamination. 522

Facility $125,128,138,211,311,312,334,338,371,381,382,413,554$ $644,713,781$, Glossary

Feet. 347

Female 215,725

Fissile Material 515

Fission Products. Table 2-2 Notes, Table 4-2 Notes, 541

Fixed 222, Table 2-2, Table 2-2 Notes, 235, Table 2-5, 365, 413, Table 4-1, Table 4-2, 515, 554, 753, 754, 761

Contamination 222, 235, 412, Table 4-1, 554, Glossary Installations. 365

Radiation Measuring Equipment. 761 
Frisk, Frisking ........................ 123 Poster, 321, 335, 338, 347, 363, Table 3B-1 Notes, Appendix 3C, 551, Glossary

Fume Hood

$\mathbf{G}$

Gamma Table 2-2 Notes, Appendix 3C, 365, Table 4-2 Notes, 461

Gas, Gaseous 411,423

General Employee Radiological Training (GERT) $612,613,621$, Table 6-1, 655, 725

Gestation $215,511,521$, Glossary

H

Hand 123 Poster, Table 2-1, 319, 325, 338, 342, 347, Appendix 3B, Appendix 3C, 552

Hazardous. $319,322,423$

Health 138, Chapter 3 Part 7, 361, 362, 363, 364, Appendix 3B, 554

Health and Safety Plans Chapter 3 Part 7

Heat Stress (Hyperthermia) $317,319,342,371$, Glossary

HEPA 464, Glossary High

Contamination Area.....123 Poster, 233, Table 2-3, 235, Table 2-5, Appendix 3A, 322, 325, 335, 336, 337, 338, 342, Chapter 4 Part 1, 411, 413, 421, 554, Table 6-1, 632, 633, Glossary

Radiation Area 234, Table 2-4, 334, 336, 342, 365, Appendix 3A, 511, 513, 552, Table 6-1, 632, 633, 655, Glossary

Hold Point. 312,324

Hypothermia (Cold Stress) 371, Glossary 
I

Indicator 371

Individual $128,138,142,211,213,222,223,231,232,236,237$, Table 2C-1, 312, 323, 333,334, 338, 381, Chapter 4 Part 1, 412, 511, 515, 521, 531, 551, 555, 611, 621, 622, 641, 642, 657, Chapter 7 Part 1, 711, 712, 721, $722,724,751,761,781,783$, Glossary

Exposure $346,551,611,781$

Records 781

Inhalation $312,381,555$

Injured Person 542

Installation 365,655

Instrument .............Table 2-2 Notes, 338, Appendix 3C, 551, 555, 562, 564, 661, 662, 663, 664, Chapter 7 Part 6, 725, 752, 753, 761

Instrumentation ............. Table 2-2 Notes, 338, 361, Table 4-2 Notes, Chapter 5 Part 6, $562,563,712$

Interlock $364,365,553,664$ Internal

Contamination Table 4-1, 522

Dose. Table 2-1 Notes, 223, 521, 722

Dosimetry 363, Chapter 5 Part 2, 522, 542 Exposure $316,522,661$ Inventory Control $661,662,663$ Investigation 411,514

\section{J}

Job Assignments $317,632,633,641$

Job Function 611,642

Job Supervisors 317 


\section{K}

Knee Table 2-1, Appendix 3C

$L$

Label 231, 236, 411, 412, Table 4-1, 413, 421, 422, 423, 431, 461, $464,562,755$

Laundry 325,461

Leak, Leaking. $431,432,464,554,751,755$

Legs. Table 2-1, Appendix 3B, Appendix 3C Lens of the Eye 213, Table 2-1, 511, 722 Line Management $312,365,511,513,551,642$ Line Manager $113,125,138,316,345,611$

Maintain

$111,141,138,222,231,311,334,335,343,381,421,431$, $512,522,531,551,554,555,562,611,613,656,711,722,723,724$, $725,751,755,761$

Maintenance. $128,138,142,311,312,381,412,562,563,564,712,761$ Medical Table 2-1 Notes, 213, 317, 365, 511, 531, 541, 542, 656

Evaluations. 531 Personnel 213,656 Members of the Public. 138, Table 2-1, 214, 336, 511, 521, 782, Glossary Minimize 121, 123 Poster, 128, 138, 312, 316, 342, 346, 381, Appendix 3B, $431,461,555,564$

Minor. Table 2-1, 311, 511, 521, Glossary Mixed Fission Products Table 2-2 Notes, Table 4-2 Notes, 541 
Monitor, Monitored, Monitoring 123 Poster, 125, 138, 222, 223, 316, 318, 334, 335, 338, 342, 346, 347, 361, 362, 363, 364, 371, 381, Table 3B-1 Notes, Appendix 3C, 421, 423, 511, 512, 514, 521, 522, Chapter 5 Part 5, 551, 552, 553, 555, 562, 655, 712, 721, 722, Chapter 7 Part 5, 751, 761, 781, 782, Glossary

Monitoring Program. $512,514,522,551$

\section{$N$}

Nasal Contamination 522

National Institute Of Standards and Technology 562,761

Neutron 231, 381, Chapter 5 Part 1, 551, 661

Nonionizing Radiation 564

Nonuniform Exposure Table 2-1 Notes, Appendix 2C, Table 2C-1

Notification 411,423

National Registry of Radiation Protection Technologists (NRRPT) …....................... 642

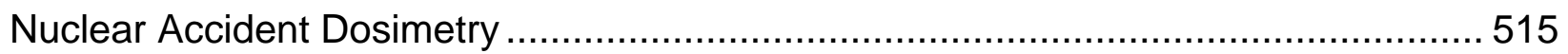

Nuclear Regulatory Commission Requirements................................. 112, 365, 431

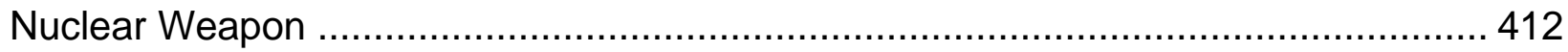

NTS RadCon Managers' Council ............113, 116, Appendix 1A, Appendix 1B, Glossary

NTS Tenant Organization.........................112, 116, 141, 157, 211, 324, 431, 511, 551, $611,712,724,725$

\section{0}

Occupational

Dose. 213, Table 2-1, Table 2-1 Notes, 381, 712, 721, 722, Glossary

Exposure $111,138,157,213,235,312,711,751$ 
Operating Table 2A-1 Notes, 337, 365, 564

Operational Check 555,761

Operations..................125, 128, 138, 213, 221, Appendix 2A, Table 2A-1 Notes, 311, $312,322,325,343,364,365,371,381,514,551,552,641,642,644$, 722,781

Oral Examination. $642,643,645$

Orientation... 121,612

Oversight. 322

\section{$\boldsymbol{P}$}

Package $231,236,312,413,423,751$

Packaging 411,413

Performance

Demonstrations $613,641,657$

Goals and Indicators 371

Test... 562

Personal

Breathing-Zone Air Sampling 555

Clothing 221, 325, Appendix 3B

Protective Equipment (PPE)... Appendix 3B, 461, Glossary

Street Clothing 461

Personnel

Contamination 221, 335, 338, Appendix 3C, 633

Dosimetry Glossary

Monitoring. 123 Poster, 128, 381, Glossary

Protection $661,662,663$

Radiation Exposure . 123

Radiological Records. 722,723 
Training 712,725

Training Records 712,725

Physical Access Controls

334, Appendix 3A

Planned Special Exposure

213, 721, Glossary

Plutonium 361,661

Policy $111,522,541$, Glossary

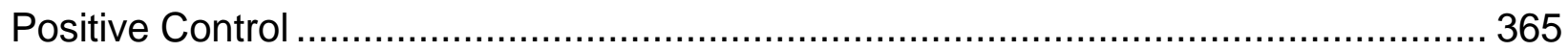

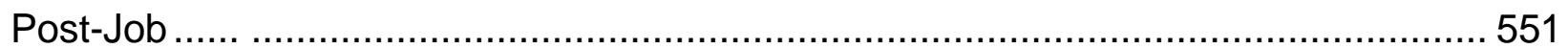

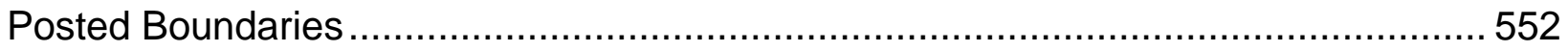

Posting ................................... 141, 123 Poster, 231, 232, 233, 234, Table 2-3, 235, Table 2-4, Table 2-5, 236, 237, 431, 621

Contaminated Soil Areas.

Table 2-3, 233

Contamination, High Contamination, Fixed Contamination And Airborne Radioactivity Areas ............................................... 235, Table 2-5

Radiation Areas 234, Table 2-4

Radioactive Material Areas 236

Requirements 222,231

Underground Radioactive Material Areas 237

Potential Radiological Conditions 231,551

Potentially Contaminated 347,554

Pre-Job $321,324,335,725$

Pre-Job Briefing $321,324,334,335,725$

Pregnant Worker Table 2-1, 215

Prenatal Radiation Exposure Glossary

Preplanning . 551

Primary Dosimeter. 511, 512, 513, Glossary 
Privacy Act . 781

Procedures... $312,321,322,336,364,365,541,562,712,725$

Procurement 431

Program $111,112,121,134,138,142,342$, Chapter 3 Part 7, 511, 512, 513, 514, 521, 522, Chapter 5 Part 3, 531, 551, 555, 613, 663, 712, 781

Protective Clothing (PC)............... 123 Poster, 128, 317, 318, 321, 325, 335, 338, 363, Appendix 3B, Table 3B-1, Table 3B-1 Notes, 412, 461, 633, Glossary

Public 111, 138, Table 2-1, 554, Glossary

$Q$

Qualification

Records 725

Standard 725, Glossary

Quality

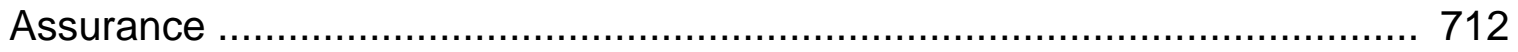

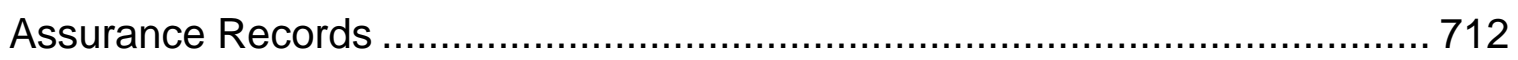

Quantities .... 431, 515

$\boldsymbol{R}$

$\operatorname{Rad}$ Table 2-4

Radiation

Area. $234,334,336,513,552,633$

Exposure $111,121,133,138,215,311,551,564,611$

Field. 334,365

Generating Device (\& Producing Equipment). $431,365,552,655$ Measuring Equipment 761

Monitors 551,553

Protection 111, 213, Chapter 5 Part 3, 642 
Safety 138,365

Source. 214, Appendix 3A, Appendix 3B, 431

Surveys 431

Symbol 231

Radioactive

Contamination 335 Material. 112, 128, 223, 231, 236, 237, Appendix 2C, 316, 333, 342, 346, 371, Chapter 4 Part 1, 411, 412, 413, 414, 421, 422, 423, 431, 542, 551, 554, 621, Glossary

Material Area 236, Glossary

Material Packaging 413

Material Storage 414

Material, Transportation of 423

Sources Table 4-1, 431

Spills. 123 Poster

Radiographers $334,365,655$

Radiological

Activities 112

Areas $221,551,554,611,656$

Buffer Area $511,514,521,551,554$

Controls 112,345

Control Deficiencies. 125

Control Hold Point $312,324,345$, Glossary

Control Instructions 123 Poster

Control Manager $113,141,142,316,345,371,414,612,613$

Control Manager Qualifications 142

Control Manual Chapter 1 Part 1

Control Operations 551

Control Organization $221,222,511,513,541,551$

Control Personnel. 123 Poster, 141, 343, 344, 346

Control Procedures. 712 
Radiological (continued)

Control Program $111,112,121,134,142,751$

Control Records 711,713

Control Technician Qualifications 144,641

Control Training 613,657

Deficiencies 125

Design . 128

Incident 712,723

Instruments. 562,563

Matters 125

Operations 138, 371

Performance. Chapter 1 Part 3

Posting 231

Records 712

Surveys 222, 323, 554, 661, 662, 664, 712, Chapter 7 Part 5, 751 Work. 111, Chapter 3 Part 1, 312, 322, 325, Chapter 3 Part 4, $344,345,412$

Work Permit (RWP) ................... 123 Poster, 312, 321, 322, 323, 324, 334, 347, $412,464,512,513,712,725,751$

Worker 213, 215, Chapter 6 Part 3, 631, 632, 633, 656

Worker I $213,334,612,613,631,632$, Table 6-1

Worker II $.213,334,335,612,613,631,633$, Table 6-1 Worker Training 725

Radionuclides Table 2-1, 223, 338, 522, 541

RAMATROL $365,423,431,783$

RCT $338,611,612,613,641,642,643,644,645$, Glossary

Record. 213, Appendix 2C, 512, 514, 554, 613, 711, 712, 713, Chapter 7 Part 2, 721, 722, 723, 725, 751, 752, 753, Chapter 7 Part 6, 761,781

Recordkeeping 713

Records Management 712 


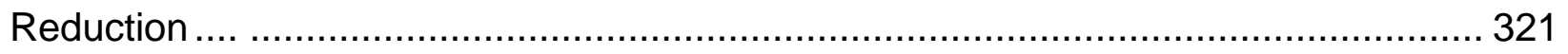

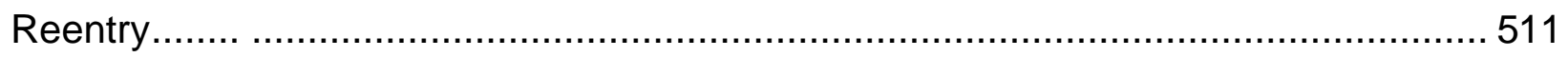

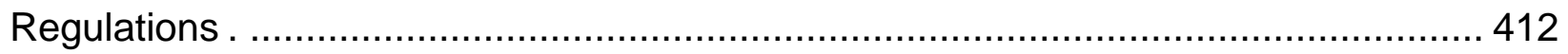

Release To

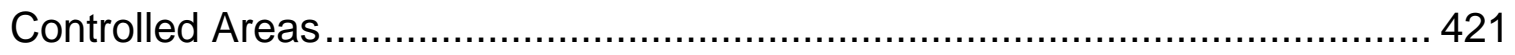

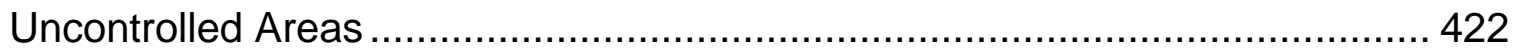

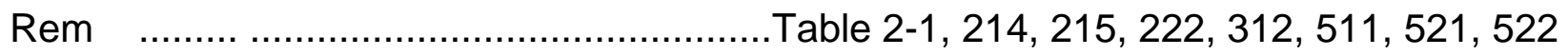

Removable Contamination ................222, Table 2-4, 316, 325, 333, 337, 413, 423, 554

Report ............................................................. $511,512,554,712,781,782,783$

Reporting .................................................................. 411, Chapter 7 Part 8, 781

Respirator......................................................... 461, Chapter 5 Part 3, 531, 555

Respiratory

Protection …...................... 316, 321, 335, 347, 371, Chapter 5 Part 3, 531, 555

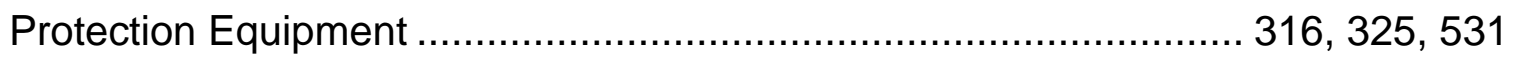

Protection Program........................................................... Chapter 5 Part 3, 531

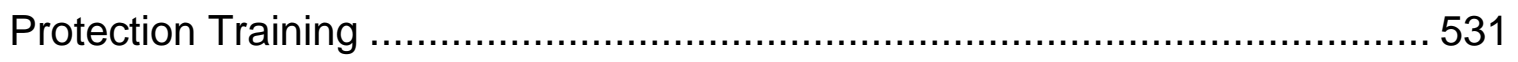

Response .................. 324, 346, Appendix 3C, 411, 423, 551, 555, 621, 633, 656, 725

RSPC

$511,531,551,554,782,783$

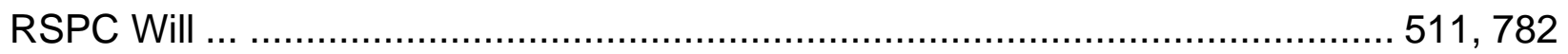

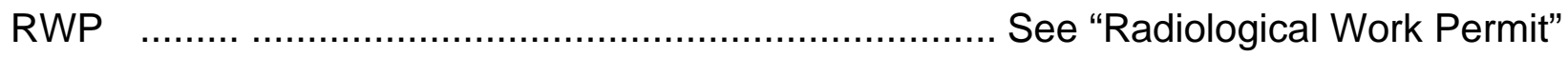

$S$

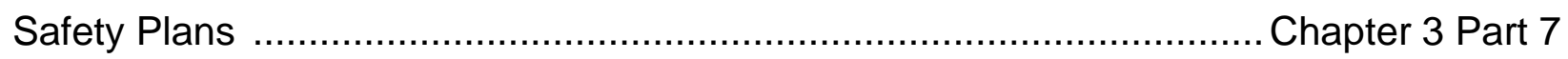

Sealed Source ........................................................ 365, Chapter 4 Part 1, 411, 431

Senior Site Executive (SSE)...........116, 121, Appendix 1A, Appendix 1C, 141, 211, 213 
Skin.

Decontamination

Soil Contamination 222,371

Source Controls 431

Spread Of Contamination. 312, 337, 342, Appendix $3 \mathrm{C}$

Step-Off Pad $325,335,554$, Glossary

Stop Work 346

Storage. 371, Chapter 4 Part 1, Table 4-1, 414

Supervision $221,345,725$

Supervisor $121,125,324,641,644,725$

Supervisory $142,644,713$

Supplemental Dosimeter 346

Surface Contamination $222,371,464$

Surveillance. 312

Survey

Frequency

Swipe/Smear Table 2-2 Notes, 431, 554 


\section{$T$}

Technical Work Document 312,382, Glossary

Temporary Shielding 312

Tenant Organization (TO) ...............112, 113, 134, 138, 141, 157, 211, 213, 325, 371, 411, 414, 422, 431, 432, Chapter 5 Part 1, 511, 521, 531, 551, 554, 611, $612,613,641,712,724,725,782,783$, Glossary

TLD Chapter 5 Part 1, Glossary

Transportation of Radioactive Materials 423

Trigger Levels $312,324,541$

\section{$\boldsymbol{U}$}

Unusual Occurrence.

Glossary

\section{$\boldsymbol{V}$}

Vacuum Cleaners 464

\section{W}

Whole Body. 213, Table 2-1, Table 2-1 Notes, Table 2A-1 Notes, Appendix 2B, Table 2B-1 Notes, 347, 512, 722

Worker Responsibilities 123

Workplace Hazards. 319 
THIS PAGE INTENTIONALLY LEFT BLANK 
APPENDIX A TO PART 835-DERIVED AIR CONCENTRATION (DAC) FOR CONTROLLING RADIATION EXPOSURE TO WORKERS AT DOE FACILITIES

APPENDIX B TO PART 835 [RESERVED]

APPENDIX C TO PART 835-DERIVED AIR CONCENTRATION (DAC) FOR WORKERS FROM EXTERNAL EXPOSURE DURING IMMERSION IN A Cloud OF AIRBorne Radioactive MATERIAL

APPENDIX D TO PART 835-SURFACE CONTAMINATION VALUES

APPENDIX E TO PART 835-VALUES FOR EsTABLISHING SEALED RAdIOACTIVE Source ACCOUNTABILITY AND RADIOACTIVE MATERIAL Posting AND LABELING REQUIREMENTS

AUTHORITY: 42 U.S.C. 2201, 7191; 50 U.S.C. 2410 .

SOURCE: 58 FR 65485, Dec. 14, 1993, unless otherwise noted.

\section{Subpart A-General Provisions}

\section{$\$ 835.1$ Scope.}

(a) General. The rules in this part establish radiation protection standards, limits, and program requirements for protecting individuals from ionizing radiation resulting from the conduct of DOE activities.

(b) Exclusion. Except as provided in paragraph (c) of this section, the requirements in this part do not apply to:

(1) Activities that are regulated through a license by the Nuclear Regulatory Commission or a State under an Agreement with the Nuclear Regulatory commission, including activities certified by the Nuclear Regulatory Commission under section 1701 of the Atomic Energy Act;

(2) Activities conducted under the authority of the Deputy Administrator for Naval Reactors, as described in Pub. L. 98-525 and 106-65;

(3) Activities conducted under the Nuclear Explosives and Weapons Surety Program relating to the prevention of accidental or unauthorized nuclear detonations;

(4) DOE activities conducted outside the United States on territory under the jurisdiction of a foreign government to the extent governed by occupational radiation protection requirements agreed to between the United States and the cognizant government

(5) Background radiation, radiation doses received as a patient for the pur- poses of medical diagnosis or therapy, or radiation doses received from participation as a subject in medical research programs; or

(6) Radioactive material on or within material, equipment, and real property which is approved for release when the radiological conditions of the material, equipment, and real property have been documented to comply with the criteria for release set forth in a DOE authorized limit which has been approved by a Secretarial Officer in consultation with the Chief Health, Safety and Security Officer.

(7) Radioactive material transportation not performed by DOE or a DOE contractor.

(c) Occupational doses received as a result of excluded activities and radioactive material transportation listed in paragraphs (b)(1) through (b)(4) and (b)(7) of this section, shall be included to the extent practicable when determining compliance with the occupational dose limits at $\$ \$ 835.202$ and 835.207, and with the limits for the embryo/fetus at $\$ 835.206$. Occupational doses resulting from authorized emergency exposures and planned special exposures shall not be considered when determining compliance with the dose limits at $\$ \S 835.202$ and 835.207.

(d) The requirements in subparts $F$ and $\mathrm{G}$ of this part do not apply to radioactive material transportation by DOE or a DOE contractor conducted:

(1) Under the continuous observation and control of an individual who is knowledgeable of and implements required exposure control measures, or

(2) In accordance with Department of Transportation regulations or DOE orders that govern such movements.

[58 FR 65485, Dec. 14, 1993, as amended at 63 FR 59679, Nov. 4, 1998; 71 FR 68733, Nov. 28, 2006; 72 FR 31922, June 8, 2007]

\section{$\$ 835.2$ Definitions.}

(a) As used in this part:

Accountable sealed radioactive source means a sealed radioactive source having a half-life equal to or greater than 30 days and an isotopic activity equal to or greater than the corresponding value provided in appendix $\mathrm{E}$ of this part. 
$\S 835.2$

Activity Median Aerodynamic Diameter $(A M A D)$ means a particle size in an aerosol where fifty percent of the activity in the aerosol is associated with particles of aerodynamic diameter greater than the AMAD.

Airborne radioactive material or airborne radioactivity means radioactive material dispersed in the air in the form of dusts, fumes, particulates, mists, vapors, or gases.

Airborne radioactivity area means any area, accessible to individuals, where:

(1) The concentration of airborne radioactivity, above natural background, exceeds or is likely to exceed the derived air concentration (DAC) values listed in appendix A or appendix $\mathrm{C}$ of this part; or

(2) An individual present in the area without respiratory protection could receive an intake exceeding 12 DAChours in a week.

ALARA means "As Low As is Reasonably Achievable," which is the approach to radiation protection to manage and control exposures (both individual and collective) to the work force and to the general public to as low as is reasonable, taking into account social, technical, economic, practical, and public policy considerations. As used in this part, ALARA is not a dose limit but a process which has the objective of attaining doses as far below the applicable limits of this part as is reasonably achievable.

Annual limit on intake (ALI) means the derived limit for the amount of radioactive material taken into the body of an adult worker by inhalation or ingestion in a year. ALI is the smaller value of intake of a given radionuclide in a year by the reference man (ICRP Publication 23) that would result in a committed effective dose of 5 rems $(0.05$ sieverts $(\mathrm{Sv}))(1 \mathrm{rem}=0.01 \mathrm{~Sv})$ or a committed equivalent dose of $50 \mathrm{rems}$ $(0.5 \mathrm{~Sv})$ to any individual organ or tissue. ALI values for intake by ingestion and inhalation of selected radionuclides are based on International Commission on Radiological Protection Publication 68, Dose Coefficients for Intakes of Radionuclides by Workers, published July, 1994 (ISBN 008042651 4). This document is available from Elsevier Science Inc., Tarrytown, NY.
10 CFR Ch. III (1-1-08 Edition)

Authorized limit means a limit on the concentration of residual radioactive material on the surfaces or within the property that has been derived consistent with DOE directives including the as low as is reasonably achievable (ALARA) process requirements, given the anticipated use of the property and has been authorized by DOE to permit the release of the property from DOE radiological control.

Background means radiation from:

(1) Naturally occurring radioactive materials which have not been technologically enhanced;

(2) Cosmic sources;

(3) Global fallout as it exists in the environment (such as from the testing of nuclear explosive devices);

(4) Radon and its progeny in concentrations or levels existing in buildings or the environment which have not been elevated as a result of current or prior activities; and

(5) Consumer products containing nominal amounts of radioactive material or producing nominal amounts of radiation.

Bioassay means the determination of kinds, quantities, or concentrations, and, in some cases, locations of radioactive material in the human body, whether by direct measurement or by analysis and evaluation of radioactive materials excreted or removed from the human body.

Calibration means to adjust and/or determine either:

(1) The response or reading of an instrument relative to a standard (e.g., primary, secondary, or tertiary) or to a series of conventionally true values; or

(2) The strength of a radiation source relative to a standard (e.g., primary, secondary, or tertiary) or conventionally true value.

Contamination area means any area, accessible to individuals, where removable surface contamination levels exceed or are likely to exceed the removable surface contamination values specified in appendix D of this part, but do not exceed 100 times those values.

Controlled area means any area to which access is managed by or for DOE to protect individuals from exposure to radiation and/or radioactive material.

Declared pregnant worker means a woman who has voluntarily declared to 


\section{Department of Energy}

her employer, in writing, her pregnancy for the purpose of being subject to the occupational dose limits to the embryo/fetus as provided in $\$ 835.206$. This declaration may be revoked, in writing, at any time by the declared pregnant worker.

Derived air concentration (DAC) means, for the radionuclides listed in appendix A of this part, the airborne concentration that equals the ALI divided by the volume of air breathed by an average worker for a working year of 2000 hours (assuming a breathing volume of $2400 \mathrm{~m}^{3}$ ). For the radionuclides listed in appendix $\mathrm{C}$ of this part, the air immersion DACs were calculated for a continuous, non-shielded exposure via immersion in a semi-infinite cloud of radioactive material. Except as noted in the footnotes to appendix A of this part, the values are based on dose coefficients from International Commission on Radiological Protection Publication 68, Dose Coefficients for Intakes of Radionuclides by Workers, published July, 1994 (ISBN 008042651 4) and the associated ICRP computer program. The ICRP Database of Dose Coefficients: Workers and Members of the Public, (ISBN 008043 8768). These materials are available from Elsevier Science Inc., Tarrytown, NY.

Derived air concentration-hour (DAChour) means the product of the concentration of radioactive material in air (expressed as a fraction or multiple of the DAC for each radionuclide) and the time of exposure to that radionuclide, in hours.

Deterministic effects means effects due to radiation exposure for which the severity varies with the dose and for which a threshold normally exists (e.g., radiation-induced opacities within the lens of the eye).

DOE means the United States Department of Energy.

DOE activity means an activity taken for or by DOE in a DOE operation or facility that has the potential to result in the occupational exposure of an individual to radiation or radioactive material. The activity may be, but is not limited to, design, construction, operation, or decommissioning. To the extent appropriate, the activity may involve a single DOE facility or operation or a combination of facilities and
$\S 835.2$

operations, possibly including an entire site or multiple DOE sites.

Entrance or access point means any location through which an individual could gain access to areas controlled for the purpose of radiation protection. This includes entry or exit portals of sufficient size to permit human entry, irrespective of their intended use.

General employee means an individual who is either a DOE or DOE contractor employee; an employee of a subcontractor to a DOE contractor; or an individual who performs work for or in conjunction with DOE or utilizes DOE facilities.

High contamination area means any area, accessible to individuals, where removable surface contamination levels exceed or are likely to exceed 100 times the removable surface contamination values specified in appendix $D$ of this part.

High radiation area means any area, accessible to individuals, in which radiation levels could result in an individual receiving an equivalent dose to the whole body in excess of 0.1 rems $(0.001 \mathrm{~Sv})$ in 1 hour at 30 centimeters from the radiation source or from any surface that the radiation penetrates.

Individual means any human being.

Member of the public means an individual who is not a general employee. An individual is not a "member of the public" during any period in which the individual receives an occupational dose.

Minor means an individual less than 18 years of age.

Monitoring means the measurement of radiation levels, airborne radioactivity concentrations, radioactive contamination levels, quantities of radioactive material, or individual doses and the use of the results of these measurements to evaluate radiological hazards or potential and actual doses resulting from exposures to ionizing radiation.

Occupational dose means an individual's ionizing radiation dose (external and internal) as a result of that individual's work assignment. Occupational dose does not include doses received as a medical patient or doses resulting from background radiation or participation as a subject in medical research programs. 
Person means any individual, corporation, partnership, firm, association, trust, estate, public or private institution, group, Government agency, any State or political subdivision of, or any political entity within a State, any foreign government or nation or other entity, and any legal successor, representative, agent or agency of the foregoing; provided that person does not include DOE or the United States Nuclear Regulatory Commission.

Radiation means ionizing radiation: alpha particles, beta particles, gamma rays, X-rays, neutrons, high-speed electrons, high-speed protons, and other particles capable of producing ions. Radiation, as used in this part, does not include non-ionizing radiation, such as radio waves or microwaves, or visible, infrared, or ultraviolet light.

Radiation area means any area, accessible to individuals, in which radiation levels could result in an individual receiving an equivalent dose to the whole body in excess of $0.005 \mathrm{rem}(0.05 \mathrm{mSv})$ in 1 hour at 30 centimeters from the source or from any surface that the radiation penetrates.

Radioactive material area means any area within a controlled area, accessible to individuals, in which items or containers of radioactive material exist and the total activity of radioactive material exceeds the applicable values provided in appendix $\mathrm{E}$ of this part.

Radioactive material transportation means the movement of radioactive material by aircraft, rail, vessel, or highway vehicle. Radioactive material transportation does not include preparation of material or packagings for transportation, storage of material awaiting transportation, or application of markings and labels required for transportation.

Radiological area means any area within a controlled area defined in this section as a "radiation area," "high radiation area," "very high radiation area," "contamination area," "high contamination area," or "airborne radioactivity area.'

Radiological worker means a general employee whose job assignment involves operation of radiation producing devices or working with radioactive materials, or who is likely to be rou- tinely occupationally exposed above 0.1 rem $(0.001 \mathrm{~Sv})$ per year total effective dose.

Real property means land and anything permanently affixed to the land such as buildings, fences and those things attached to the buildings, such as light fixtures, plumbing and heating fixtures.

Real-time air monitoring means measurement of the concentrations or quantities of airborne radioactive materials on a continuous basis.

Respiratory protective device means an apparatus, such as a respirator, worn by an individual for the purpose of reducing the individual's intake of airborne radioactive materials.

Sealed radioactive source means a radioactive source manufactured, obtained, or retained for the purpose of utilizing the emitted radiation. The sealed radioactive source consists of a known or estimated quantity of radioactive material contained within a sealed capsule, sealed between layer(s) of non-radioactive material, or firmly fixed to a non-radioactive surface by electroplating or other means intended to prevent leakage or escape of the radioactive material. Sealed radioactive sources do not include reactor fuel elements, nuclear explosive devices, and radioisotope thermoelectric generators.

Source leak test means a test to determine if a sealed radioactive source is leaking radioactive material.

Special tritium compound (STC) means any compound, except for $\mathrm{H}_{2} \mathrm{O}$, that contains tritium, either intentionally (e.g., by synthesis) or inadvertently (e.g., by contamination mechanisms).

Stochastic effects means malignant and hereditary diseases for which the probability of an effect occurring, rather than its severity, is regarded as a function of dose without a threshold, for radiation protection purposes.

Very high radiation area means any area, accessible to individuals, in which radiation levels could result in an individual receiving an absorbed dose in excess of 500 rads (5 grays) in one hour at 1 meter from a radiation source or from any surface that the radiation penetrates.

Week means a period of seven consecutive days. 


\section{Department of Energy}

Year means the period of time beginning on or near January 1 and ending on or near December 31 of that same year used to determine compliance with the provisions of this part. The starting and ending date of the year used to determine compliance may be changed, provided that the change is made at the beginning of the year and that no day is omitted or duplicated in consecutive years.

(b) As used in this part to describe various aspects of radiation dose:

Absorbed dose (D) means the average energy imparted by ionizing radiation to the matter in a volume element. The absorbed dose is expressed in units of rad (or gray) ( $1 \mathrm{rad}=0.01$ grays)

Committed effective dose $\left(\mathrm{E}_{50}\right)$ means the sum of the committed equivalent doses to various tissues or organs in the body $\left(\mathrm{H}_{\mathrm{T}, 50}\right)$, each multiplied by the appropriate tissue weighting factor $\left(\mathrm{w}_{\mathrm{T}}\right)$ - that is, $\mathrm{E}_{50}=\Sigma \mathrm{W}_{\mathrm{T}} \mathrm{H}_{\mathrm{T}, 50}+$ $\mathrm{W}_{\text {Remainder }} \mathrm{H}_{\text {Remainder,50. }}$. Where $\mathrm{w}_{\text {Remainder }}$ is the tissue weighting factor assigned to the remainder organs and tissues and $\mathrm{H}_{\text {Remainder,50 }}$ is the committed equivalent dose to the remainder organs and tissues. Committed effective dose is expressed in units of rem (or Sv).

Committed equivalent dose $\left(\mathrm{H}_{\mathrm{T}, 50}\right)$ means the equivalent dose calculated to be received by a tissue or organ over a 50-year period after the intake of a radionuclide into the body. It does not include contributions from radiation sources external to the body. Committed equivalent dose is expressed in units of rem (or Sv).

Cumulative total effective dose means the sum of all total effective dose values recorded for an individual plus, for occupational exposures received before the implementation date of this amendment, the cumulative total effective dose equivalent (as defined in the November 4, 1998 amendment to this rule) values recorded for an individual, where available, for each year occupational dose was received, beginning January 1, 1989.
$\S 835.2$

Dose is a general term for absorbed dose, equivalent dose, effective dose, committed equivalent dose, committed effective dose, or total effective dose as defined in this part.

Effective dose (E) means the summation of the products of the equivalent dose received by specified tissues or organs of the body $\left(\mathrm{H}_{\mathrm{T}}\right)$ and the appropriate tissue weighting factor $\left(\mathrm{w}_{\mathrm{T}}\right)$ that is, $\mathrm{E}=\Sigma \mathrm{w}_{\mathrm{T}} \mathrm{H}_{\mathrm{T}}$. It includes the dose from radiation sources internal and/or external to the body. For purposes of compliance with this part, equivalent dose to the whole body may be used as effective dose for external exposures. The effective dose is expressed in units of rem (or Sv).

Equivalent dose $\left(\mathrm{H}_{\mathrm{T}}\right)$ means the product of average absorbed dose $\left(\mathrm{D}_{\mathrm{T}, \mathrm{R}}\right)$ in rad (or gray) in a tissue or organ ( $\mathrm{T}$ ) and a radiation ( $\mathrm{R}$ ) weighting factor $\left(w_{R}\right)$. For external dose, the equivalent dose to the whole body is assessed at a depth of $1 \mathrm{~cm}$ in tissue; the equivalent dose to the lens of the eye is assessed at a depth of $0.3 \mathrm{~cm}$ in tissue, and the equivalent dose to the extremity and skin is assessed at a depth of $0.007 \mathrm{~cm}$ in tissue. Equivalent dose is expressed in units of rem (or Sv).

External dose or exposure means that portion of the equivalent dose received from radiation sources outside the body (i.e., "external sources").

Extremity means hands and arms below the elbow or feet and legs below the knee.

Internal dose or exposure means that portion of the equivalent dose received from radioactive material taken into the body (i.e., "internal sources").

Radiation weighting factor $\left(\mathrm{w}_{\mathrm{R}}\right)$ means the modifying factor used to calculate the equivalent dose from the average tissue or organ absorbed dose; the absorbed dose (expressed in rad or gray) is multiplied by the appropriate radiation weighting factor. The radiation weighting factors to be used for determining equivalent dose in rem are as follows:

RADIATION WEIGHTING FACTORS ${ }^{1}$, $W_{R}$

\begin{tabular}{|c|c|}
\hline Type and energy range & $\begin{array}{l}\text { Radiation } \\
\text { weighting } \\
\text { factor }\end{array}$ \\
\hline 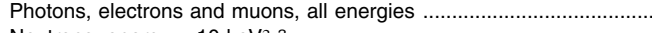 & \\
\hline
\end{tabular}


RADIATION WEIGHTING FACTORS ${ }^{1}, \mathrm{~W}_{\mathrm{R}}$-Continued

\begin{tabular}{|c|c|}
\hline Type and energy range & $\begin{array}{l}\text { Radiation } \\
\text { weighting } \\
\text { factor }\end{array}$ \\
\hline Neutrons, energy $10 \mathrm{keV}$ to $100 \mathrm{keV}^{2,3}$ & 10 \\
\hline Neutrons, energy $>100 \mathrm{keV}$ to $2 \mathrm{MeV}^{2,3}$ & 20 \\
\hline 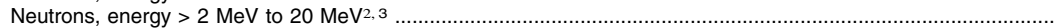 & 10 \\
\hline Neutrons, energy $>20 \mathrm{MeV}^{2,3}$................ & 5 \\
\hline Protons, other than recoil protons, energy $>2 \mathrm{MeV}$ & 5 \\
\hline Alpha particles, fission fragments, heavy nuclei & 20 \\
\hline
\end{tabular}
Alpha particles, fission fragments, heavy nuclei

1 All values relate to the radiation incident on the body or, for internal sources, emitted from the source.

2 When spectral data are insufficient to identify the energy of the neutrons, a radiation weighting factor of 20 shall be used.

政 neutron radiation weighting factor value:

$$
\mathrm{w}_{\mathrm{R}}=5+17 \exp \left[\frac{-\left(\ln \left(2 \mathrm{E}_{\mathrm{n}}\right)\right)^{2}}{6}\right] \text { Where } \mathrm{E}_{\mathrm{n}} \text { is the neutron energy in MeV. }
$$

Tissue weighting factor $\left(\mathrm{w}_{\mathrm{T}}\right)$ means the fraction of the overall health risk, resulting from uniform, whole body irradiation, attributable to specific tissue (T). The equivalent dose to tissue, $\left(\mathrm{H}_{\mathrm{T}}\right)$, is multiplied by the appropriate tissue weighting factor to obtain the effective dose (E) contribution from that tissue. The tissue weighting factors are as follows:

\section{TISSUE WEIGHTING FACTORS FOR VARIOUS ORGANS AND TISSUES}

\begin{tabular}{|c|c|}
\hline Organs or tissues, $\mathrm{T}$ & $\begin{array}{c}\text { Tissue } \\
\text { weighting } \\
\text { factor, } w_{T}\end{array}$ \\
\hline Gonads & 0.20 \\
\hline Red bone marrow & 0.12 \\
\hline 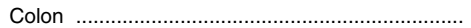 & 0.12 \\
\hline 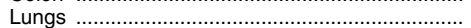 & 0.12 \\
\hline 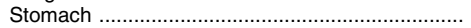 & 0.12 \\
\hline Bladder .............................. & 0.05 \\
\hline Breast & 0.05 \\
\hline Liver ............................... & 0.05 \\
\hline Esophagus & 0.05 \\
\hline 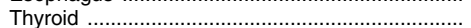 & 0.05 \\
\hline 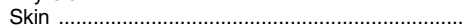 & 0.01 \\
\hline Bone surfaces & 0.01 \\
\hline Remainder $^{1}$. & 0.05 \\
\hline Whole body ${ }^{2}$ & 1.00 \\
\hline
\end{tabular}

1 "Remainder" means the following additional tissues and organs and their masses, in grams, following parenthetically: adrenals (14), brain (1400), extrathoracic airways (15), smal intestine (640), kidneys $(310)$, muscle $(28,000)$, pancreas (100), spleen (180), thymus (20), and uterus (80). The equivalent dose to the remainder tissues $\left(\mathrm{H}_{\text {remainder }}\right)$, is normally calculated as the mass-weighted mean dose to the preceeding ten organs and tissues. In those cases in which the mos highly irradiated remainder tissue or organ receives the highest equivalent dose of all the organs, a weighting factor of 0.025 (half of remainder) is applied to that tissue or organ and 0.025 (half of remainder) to the mass-weighted equivalen dose in the rest of the remainder tissues and organs to give the remainder equivalent dose.

external irradiation of the whole body, a tissue weighting factor $\left(\mathrm{w}_{\mathrm{T}}\right)$ equal to 1 may be used in
determination of the effective dose.
Total effective dose (TED) means the sum of the effective dose (for external exposures) and the committed effective dose.

Whole body means, for the purposes of external exposure, head, trunk (including male gonads), arms above and including the elbow, or legs above and including the knee.

(c) Terms defined in the Atomic Energy Act of 1954 or in 10 CFR part 820 and not defined in this part are used consistent with their meanings given in the Atomic Energy Act of 1954 or in 10 CFR part 820 .

[72 FR 31922, June 8, 2007]

\section{\$ 835.3 General rule.}

(a) No person or DOE personnel shall take or cause to be taken any action inconsistent with the requirements of:

(1) This part; or

(2) Any program, plan, schedule, or other process established by this part.

(b) With respect to a particular $\mathrm{DOE}$ activity, contractor management shall be responsible for compliance with the requirements of this part.

(c) Where there is no contractor for a DOE activity, DOE shall ensure implementation of and compliance with the requirements of this part.

(d) Nothing in this part shall be construed as limiting actions that may be necessary to protect health and safety.

(e) For those activities that are required by $\S \S 835.102,835.901(\mathrm{e}), 835.1202$ (a), and 835.1202(b), the time interval to 
conduct these activities may be extended by a period not to exceed 30 days to accommodate scheduling needs.

[58 FR 65485, Dec. 14, 1993, as amended at 63 FR 59682, Nov. 4, 1998]

\section{\$835.4 Radiological units.}

Unless otherwise specified, the quantities used in the records required by this part shall be clearly indicated in special units of curie, rad, roentgen, or rem, including multiples and subdivisions of these units, or other conventional units, such as, dpm, dpm/100 $\mathrm{cm}^{2}$ or mass units. The SI units, becquerel $(\mathrm{Bq})$, gray $(\mathrm{Gy})$, and sievert ( $\mathrm{Sv})$, may be provided parenthetically for reference with scientific standards.

[72 FR 31925, June 8, 2007]

\section{Subpart B-Management and Administrative Requirements}

$\S 835.101$ Radiation protection programs.

(a) A DOE activity shall be conducted in compliance with a documented radiation protection program (RPP) as approved by the DOE.

(b) The DOE may direct or make modifications to a RPP.

(c) The content of each RPP shall be commensurate with the nature of the activities performed and shall include formal plans and measures for applying the as low as reasonably achievable (ALARA) process to occupational exposure.

(d) The RPP shall specify the existing and/or anticipated operational tasks that are intended to be within the scope of the RPP. Except as provided in $\$ 835.101(\mathrm{~h})$, any task outside the scope of a RPP shall not be initiated until an update of the RPP is approved by DOE.

(e) The content of the RPP shall address, but shall not necessarily be limited to, each requirement in this part.

(f) The RPP shall include plans, schedules, and other measures for achieving compliance with regulations of this part. Unless otherwise specified in this part, compliance with the amendments to this part published on June 8, 2007 shall be achieved no later than July 9, 2010. (g) An update of the RPP shall be submitted to DOE:

(1) Whenever a change or an addition to the RPP is made;

(2) Prior to the initiation of a task not within the scope of the RPP; or

(3) Within 180 days of the effective date of any modifications to this part.

(h) Changes, additions, or updates to the RPP may become effective without prior Department approval only if the changes do not decrease the effectiveness of the RPP and the RPP, as changed, continues to meet the requirements of this part. Proposed changes that decrease the effectiveness of the RPP shall not be implemented without submittal to and approval by the Department.

(i) An initial RPP or an update shall be considered approved 180 days after its submission unless rejected by DOE at an earlier date.

[58 FR 65485, Dec. 14, 1993, as amended at 63 FR 59682, Nov. 4, 1998; 72 FR 31925, June 8, 2007]

\section{\$835.102 Internal audits.}

Internal audits of the radiation protection program, including examination of program content and implementation, shall be conducted through a process that ensures that all functional elements are reviewed no less frequently than every 36 months.

[63 FR 59682, Nov. 4, 1998]

\section{$\S 835.103$ Education, training and} skills.

Individuals responsible for developing and implementing measures necessary for ensuring compliance with the requirements of this part shall have the appropriate education, training, and skills to discharge these responsibilities.

[63 FR 59682, Nov. 4, 1998]

\section{$\$$ 835.104 Written procedures.}

Written procedures shall be developed and implemented as necessary to ensure compliance with this part, commensurate with the radiological hazards created by the activity and consistent with the education, training, 
and skills of the individuals exposed to those hazards.

[63 FR 59682, Nov. 4, 1998]

\section{Subpart C-Standards for Internal and External Exposure}

$\S 835.201$ [Reserved]

$\$ 835.202$ Occupational dose limits for general employees.

(a) Except for planned special exposures conducted consistent with $\$ 835.204$ and emergency exposures authorized in accordance with $\$ 835.1302$, the occupational dose received by general employees shall be controlled such that the following limits are not exceeded in a year:

(1) A total effective dose of 5 rems $(0.05 \mathrm{~Sv})$;

(2) The sum of the equivalent dose to the whole body for external exposures and the committed equivalent dose to any organ or tissue other than the skin or the lens of the eye of 50 rems $(0.5$ $\mathrm{Sv})$;

(3) An equivalent dose to the lens of the eye of 15 rems $(0.15 \mathrm{~Sv})$; and

(4) The sum of the equivalent dose to the skin or to any extremity for external exposures and the committed equivalent dose to the skin or to any extremity of 50 rems $(0.5 \mathrm{~Sv})$.

(b) All occupational doses received during the current year, except doses resulting from planned special exposures conducted in compliance with $\S 835.204$ and emergency exposures authorized in accordance with $\$ 835.1302$, shall be included when demonstrating compliance with $\S 835.202(\mathrm{a})$ and 835.207.

(c) Doses from background, therapeutic and diagnostic medical radiation, and participation as a subject in medical research programs shall not be included in dose records or in the assessment of compliance with the occupational dose limits.

[58 FR 65485, Dec. 14, 1993, as amended at 63 FR 59682, Nov. 4, 1998; 72 FR 31926, June 8 , 2007]

$\$ 835.203$ Combining internal and external equivalent doses.

(a) The total effective dose during a year shall be determined by summing the effective dose from external exposures and the committed effective dose from intakes during the year.

(b) Determinations of the effective dose shall be made using the radiation and tissue weighting factor values provided in $\S 835.2$.

[72 FR 31926, June 8, 2007]

\section{\$ 835.204 Planned special exposures.}

(a) A planned special exposure may be authorized for a radiological worker to receive doses in addition to and accounted for separately from the doses received under the limits specified in $\S 835.202$ (a), provided that each of the following conditions is satisfied:

(1) The planned special exposure is considered only in an exceptional situation when alternatives that might prevent a radiological worker from exceeding the limits in $\S 835.202$ (a) are unavailable or impractical;

(2) The contractor management (and employer, if the employer is not the contractor) specifically requests the planned special exposure, in writing: and

(3) Joint written approval is received from the appropriate DOE Headquarters program office and the Secretarial Officer responsible for environment, safety and health matters.

(b) Prior to requesting an individual to participate in an authorized planned special exposure, the individual's dose from all previous planned special exposures and all doses in excess of the occupational dose limits shall be determined.

(c) An individual shall not receive a planned special exposure that, in addition to the doses determined in $\$ 835.204(\mathrm{~b})$, would result in a dose exceeding the following:

(1) In a year, the numerical values of the dose limits established at $\S 835.202(\mathrm{a})$; and

(2) Over the individual's lifetime, five times the numerical values of the dose limits established at $\S 835.202$ (a).

(d) Prior to a planned special exposure, written consent shall be obtained from each individual involved. Each such written consent shall include:

(1) The purpose of the planned operations and procedures to be used; 


\section{Department of Energy}

(2) The estimated doses and associated potential risks and specific radiological conditions and other hazards which might be involved in performing the task; and

(3) Instructions on the measures to be taken to keep the dose ALARA considering other risks that may be present.

(e) Records of the conduct of a planned special exposure shall be maintained and a written report submitted within 30 days after the planned special exposure to the approving organizations identified in $\S 835.204(\mathrm{a})(3)$.

(f) The dose from planned special exposures is not to be considered in controlling future occupational dose of the individual under $\$ 835.202(\mathrm{a})$, but is to be included in records and reports required under this part.

[58 FR 65485, Dec. 14, 1993, as amended at 63 FR 59682, Nov. 4, 1998]

$\$$ 835.205 Determination of compliance for non-uniform exposure of the skin.

(a) Non-uniform exposures of the skin from X-rays, beta radiation, and/or radioactive material on the skin are to be assessed as specified in this section.

(b) For purposes of demonstrating compliance with $\$ 835.202(a)(4)$, assessments shall be conducted as follows:

(1) Area of skin irradiated is $100 \mathrm{~cm}^{2}$ or more. The non-uniform equivalent dose received during the year shall be averaged over the $100 \mathrm{~cm}^{2}$ of the skin receiving the maximum dose, added to any uniform equivalent dose also received by the skin, and recorded as the equivalent dose to any extremity or skin for the year.

(2) Area of skin irradiated is $10 \mathrm{~cm}^{2}$ or more, but is less than $100 \mathrm{~cm}^{2}$. The nonuniform equivalent dose $(\mathrm{H})$ to the irradiated area received during the year shall be added to any uniform equivalent dose also received by the skin and recorded as the equivalent dose to any extremity or skin for the year. $\mathrm{H}$ is the equivalent dose averaged over the 1 $\mathrm{cm}^{2}$ of skin receiving the maximum absorbed dose, D, reduced by the fraction $\mathrm{f}$, which is the irradiated area in $\mathrm{cm}^{2}$ divided by $100 \mathrm{~cm}^{2}$ (i.e., $\mathrm{H}=\mathrm{fD}$ ). In no case shall a value of $f$ less than 0.1 be used.
$\S 835.208$

(3) Area of skin irradiated is less than $10 \mathrm{~cm}^{2}$. The non-uniform equivalent dose shall be averaged over the $1 \mathrm{~cm}^{2}$ of skin receiving the maximum dose. This equivalent dose shall:

(i) Be recorded in the individual's occupational exposure history as a special entry; and

(ii) Not be added to any other equivalent dose to any extremity or skin for the year.

[58 FR 65485, Dec. 14, 1993, as amended at 72 FR 31926, June 8, 2007]

\section{\$ 835.206 Limits for the embryo/fetus.}

(a) The equivalent dose limit for the embryo/fetus from the period of conception to birth, as a result of occupational exposure of a declared pregnant worker, is 0.5 rem $(0.005 \mathrm{~Sv})$.

(b) Substantial variation above a uniform exposure rate that would satisfy the limits provided in $\$ 835.206$ (a) shall be avoided.

(c) If the equivalent dose to the embryo/fetus is determined to have already exceeded 0.5 rem $(0.005 \mathrm{~Sv})$ by the time a worker declares her pregnancy, the declared pregnant worker shall not be assigned to tasks where additional occupational exposure is likely during the remaining gestation period.

[58 FR 65485, Dec. 14, 1993, as amended at 72 FR 31926, June 8, 2007]

\section{$\$ 835.207$ Occupational dose limits for} minors.

The dose limits for minors occupationally exposed to radiation and/or radioactive materials at a DOE activity are 0.1 rem $(0.001 \mathrm{~Sv})$ total effective dose in a year and 10 percent of the occupational dose limits specified at $\S 835.202(\mathrm{a})(3)$ and (a)(4).

[72 FR 31926, June 8, 2007]

$\$ 835.208$ Limits for members of the public entering a controlled area.

The total effective dose limit for members of the public exposed to radiation and/or radioactive material during access to a controlled area is 0.1 rem $(0.001 \mathrm{~Sv})$ in a year.

[72 FR 31926, June 8, 2007] 
$\S 835.209$ Concentrations of radioactive material in air.

(a) The derived air concentration (DAC) values given in appendices $\mathrm{A}$ and $\mathrm{C}$ of this part shall be used in the control of occupational exposures to airborne radioactive material.

(b) The estimation of internal dose shall be based on bioassay data rather than air concentration values unless bioassay data are:

(1) Unavailable;

(2) Inadequate; or

(3) Internal dose estimates based on air concentration values are demonstrated to be as or more accurate.

[58 FR 65485, Dec. 14, 1993, as amended at 63 FR 59682, Nov. 4, 1998]

\section{Subpart $D$ [Reserved]}

\section{Subpart E-Monitoring of Individuals and Areas}

\$ 835.401 General requirements.

(a) Monitoring of individuals and areas shall be performed to:

(1) Demonstrate compliance with the regulations in this part;

(2) Document radiological conditions;

(3) Detect changes in radiological conditions;

(4) Detect the gradual buildup of radioactive material;

(5) Verify the effectiveness of engineered and administrative controls in containing radioactive material and reducing radiation exposure; and

(6) Identify and control potential sources of individual exposure to radiation and/or radioactive material.

(b) Instruments and equipment used for monitoring shall be:

(1) Periodically maintained and calibrated on an established frequency;

(2) Appropriate for the type(s), levels, and energies of the radiation(s) encountered;

(3) Appropriate for existing environmental conditions; and

(4) Routinely tested for operability.

[58 FR 65485, Dec. 14, 1993, as amended at 63 FR 59682, Nov. 4, 1998; 72 FR 31926, June 8, 2007]

\$835.402 Individual monitoring.

(a) For the purpose of monitoring individual exposures to external radi- ation, personnel dosimeters shall be provided to and used by:

(1) Radiological workers who, under typical conditions, are likely to receive one or more of the following:

(i) An effective dose of 0.1 rem $(0.001$ $\mathrm{Sv})$ or more in a year;

(ii) An equivalent dose to the skin or to any extremity of 5 rems $(0.05 \mathrm{~Sv})$ or more in a year;

(iii) An equivalent dose to the lens of the eye of 1.5 rems $(0.015 \mathrm{~Sv})$ or more in a year;

(2) Declared pregnant workers who are likely to receive from external sources an equivalent dose to the embryo/fetus in excess of 10 percent of the applicable limit at $\S 835.206$ (a);

(3) Occupationally exposed minors likely to receive a dose in excess of 50 percent of the applicable limits at $\$ 835.207$ in a year from external sources;

(4) Members of the public entering a controlled area likely to receive a dose in excess of 50 percent of the limit at $\S 835.208$ in a year from external sources; and

(5) Individuals entering a high or very high radiation area.

(b) External dose monitoring programs implemented to demonstrate compliance with $\$ 835.402$ (a) shall be adequate to demonstrate compliance with the dose limits established in subpart $\mathrm{C}$ of this part and shall be:

(1) Accredited, or excepted from accreditation, in accordance with the DOE Laboratory Accreditation Program for Personnel Dosimetry; or

(2) Determined by the Secretarial Officer responsible for environment, safety and health matters to have performance substantially equivalent to that of programs accredited under the DOE Laboratory Accreditation Program for Personnel Dosimetry.

(c) For the purpose of monitoring individual exposures to internal radiation, internal dosimetry programs (including routine bioassay programs) shall be conducted for:

(1) Radiological workers who, under typical conditions, are likely to receive a committed effective dose of 0.1 rem $(0.001 \mathrm{~Sv})$ or more from all occupational radionuclide intakes in a year; 


\section{Department of Energy}

(2) Declared pregnant workers likely to receive an intake or intakes resulting in an equivalent dose to the embryo/fetus in excess of 10 percent of the limit stated at $\$ 835.206$ (a);

(3) Occupationally exposed minors who are likely to receive a dose in excess of 50 percent of the applicable limit stated at $\S 835.207$ from all radionuclide intakes in a year; or

(4) Members of the public entering a controlled area likely to receive a dose in excess of 50 percent of the limit stated at $\$ 835.208$ from all radionuclide intakes in a year.

(d) Internal dose monitoring programs implemented to demonstrate compliance with $\S 835.402$ (c) shall be adequate to demonstrate compliance with the dose limits established in subpart $\mathrm{C}$ of this part and shall be:

(1) Accredited, or excepted from accreditation, in accordance with the DOE Laboratory Accreditation Program for Radiobioassay; or,

(2) Determined by the Secretarial Officer responsible for environment, safety and health matters to have performance substantially equivalent to that of programs accredited under the DOE Laboratory Accreditation Program for Radiobioassy.

[63 FR 59683, Nov. 4, 1998, as amended at 72 FR 31926, June 8, 2007]

\section{\$ 835.403 Air monitoring.}

(a) Monitoring of airborne radioactivity shall be performed:

(1) Where an individual is likely to receive an exposure of 40 or more DAChours in a year; or

(2) As necessary to characterize the airborne radioactivity hazard where respiratory protective devices for protection against airborne radionuclides have been prescribed.

(b) Real-time air monitoring shall be performed as necessary to detect and provide warning of airborne radioactivity concentrations that warrant immediate action to terminate inhalation of airborne radioactive material.

[63 FR 59683, Nov. 4, 1998]

$\S 835.405$

\section{$\S 835.404$ [Reserved]}

$\$ 835.405$ Receipt of packages containing radioactive material.

(a) If packages containing quantities of radioactive material in excess of a Type A quantity (as defined at $10 \mathrm{CFR}$ 71.4) are expected to be received from radioactive material transportation, arrangements shall be made to either:

(1) Take possession of the package when the carrier offers it for delivery; or

(2) Receive notification as soon as practicable after arrival of the package at the carrier's terminal and to take possession of the package expeditiously after receiving such notification.

(b) Upon receipt from radioactive material transportation, external surfaces of packages known to contain radioactive material shall be monitored if the package:

(1) Is labeled with a Radioactive White I, Yellow II, or Yellow III label (as specified at 49 CFR 172.403 and 172.436-440); or

(2) Has been transported as low specific activity material (as defined at 10 CFR 71.4) on an exclusive use vehicle (as defined at 10 CFR 71.4); or

(3) Has evidence of degradation, such as packages that are crushed, wet, or damaged.

(c) The monitoring required by paragraph (b) of this section shall include:

(1) Measurements of removable contamination levels, unless the package contains only special form (as defined at $10 \mathrm{CFR} 71.4$ ) or gaseous radioactive material; and

(2) Measurements of the radiation levels, if the package contains a Type B quantity (as defined at 10 CFR 71.4) of radioactive material.

(d) The monitoring required by paragraph (b) of this section shall be completed as soon as practicable following receipt of the package, but not later than 8 hours after the beginning of the working day following receipt of the package.

(e) Monitoring pursuant to $\$ 835.405$ (b) is not required for packages transported on a DOE site which have remained under the continuous observation and control of a DOE employee or DOE contractor employee who is 
knowledgeable of and implements required exposure control measures.

[63 FR 59683, Nov. 4, 1998, as amended at 72 FR 31926, June 8, 2007]

\section{Subpart F-Entry Control Program}

\section{\$835.501 Radiological areas.}

(a) Personnel entry control shall be maintained for each radiological area.

(b) The degree of control shall be commensurate with existing and potential radiological hazards within the area.

(c) One or more of the following methods shall be used to ensure control:

(1) Signs and barricades;

(2) Control devices on entrances;

(3) Conspicuous visual and/or audible alarms;

(4) Locked entrance ways; or

(5) Administrative controls.

(d) Written authorizations shall be required to control entry into and perform work within radiological areas. These authorizations shall specify radiation protection measures commensurate with the existing and potential hazards.

(e) No control(s) shall be installed at any radiological area exit that would prevent rapid evacuation of personnel under emergency conditions.

[58 FR 65485, Dec. 14, 1993, as amended at 63 FR 59684, Nov. 4, 1998]

$\$ 835.502$ High and very high radiation areas.

(a) The following measures shall be implemented for each entry into a high radiation area:

(1) The area shall be monitored as necessary during access to determine the exposure rates to which the individuals are exposed; and

(2) Each individual shall be monitored by a supplemental dosimetry device or other means capable of providing an immediate estimate of the individual's integrated equivalent dose to the whole body during the entry.

(b) Physical controls. One or more of the following features shall be used for each entrance or access point to a high radiation area where radiation levels exist such that an individual could exceed an equivalent dose to the whole body of 1 rem (0.01 sievert) in any one hour at 30 centimeters from the source or from any surface that the radiation penetrates:

(1) A control device that prevents entry to the area when high radiation levels exist or upon entry causes the radiation level to be reduced below that level defining a high radiation area;

(2) A device that functions automatically to prevent use or operation of the radiation source or field while individuals are in the area;

(3) A control device that energizes a conspicuous visible or audible alarm signal so that the individual entering the high radiation area and the supervisor of the activity are made aware of the entry;

(4) Entryways that are locked. During periods when access to the area is required, positive control over each entry is maintained;

(5) Continuous direct or electronic surveillance that is capable of preventing unauthorized entry;

(6) A control device that will automatically generate audible and visual alarm signals to alert personnel in the area before use or operation of the radiation source and in sufficient time to permit evacuation of the area or activation of a secondary control device that will prevent use or operation of the source.

(c) Very high radiation areas. In addition to the above requirements, additional measures shall be implemented to ensure individuals are not able to gain unauthorized or inadvertent access to very high radiation areas.

(d) No control(s) shall be established in a high or very high radiation area that would prevent rapid evacuation of personnel.

[58 FR 65485, Dec. 14, 1993, as amended at 63 FR 59684, Nov. 4, 1998; 72 FR 31926, June 8, 2007]

\section{Subpart G-Posting and Labeling}

\section{\$ 835.601 General requirements.}

(a) Except as otherwise provided in this subpart, postings and labels required by this subpart shall include the standard radiation warning trefoil in black or magenta imposed upon a yellow background. 


\section{Department of Energy}

(b) Signs required by this subpart shall be clearly and conspicuously posted and may include radiological protection instructions.

(c) The posting and labeling requirements in this subpart may be modified to reflect the special considerations of DOE activities conducted at private residences or businesses. Such modifications shall provide the same level of protection to individuals as the existing provisions in this subpart.

[63 FR 59684, Nov. 4, 1998]

\section{$\$ 835.602$ Controlled areas.}

(a) Each access point to a controlled area (as defined at $\S 835.2$ ) shall be posted whenever radiological areas or radioactive material areas exist in the area. Individuals who enter only controlled areas without entering radiological areas or radioactive material areas are not expected to receive a total effective dose of more than 0.1 rem (0.001 sievert) in a year.

(b) Signs used for this purpose may be selected by the contractor to avoid conflict with local security requirements.

[58 FR 65485, Dec. 14, 1993, as amended at 63 FR 59684, Nov. 4, 1998; 72 FR 31926, June 8, 2007]

\$ 835.603 Radiological areas and radioactive material areas.

Each access point to radiological areas and radioactive material areas (as defined at §835.2) shall be posted with conspicuous signs bearing the wording provided in this section.

(a) Radiation area. The words "Caution, Radiation Area" shall be posted at each radiation area.

(b) High radiation area. The words "Caution, High Radiation Area" or "Danger, High Radiation Area" shall be posted at each high radiation area.

(c) Very high radiation area. The words "Grave Danger, Very High Radiation Area" shall be posted at each very high radiation area.

(d) Airborne radioactivity area. The words "Caution, Airborne Radioactivity Area" or "Danger, Airborne Radioactivity Area" shall be posted at each airborne radioactivity area.
$\S 835.605$

(e) Contamination area. The words "Caution, Contamination Area" shall be posted at each contamination area.

(f) High contamination area. The words "Caution, High Contamination Area" or "Danger, High Contamination Area" shall be posted at each high contamination area.

(g) Radioactive material area. The words "Caution, Radioactive Material(s)" shall be posted at each radioactive material area.

[63 FR 59684, Nov. 4, 1998]

\section{$\$ 835.604$ Exceptions to posting re- quirements.}

(a) Areas may be excepted from the posting requirements of $\$ 835.603$ for periods of less than 8 continuous hours when placed under continuous observation and control of an individual knowledgeable of, and empowered to implement, required access and exposure control measures.

(b) Areas may be excepted from the radioactive material area posting requirements of $\S 835.603(\mathrm{~g})$ when:

(1) Posted in accordance with $\S \S 835.603$ (a) through (f); or

(2) Each item or container of radioactive material is labeled in accordance with this subpart such that individuals entering the area are made aware of the hazard; or

(3) The radioactive material of concern consists solely of structures or installed components which have been activated (i.e., such as by being exposed to neutron radiation or particles produced by an accelerator).

(c) Areas containing only packages received from radioactive material transportation labeled and in non-degraded condition need not be posted in accordance with $\$ 835.603$ until the packages are monitored in accordance with $\S 835.405$.

[63 FR 59684, Nov. 4, 1998]

\section{$\$ 835.605$ Labeling items and con- tainers.}

Except as provided at $\S 835.606$, each item or container of radioactive material shall bear a durable, clearly visible label bearing the standard radiation warning trefoil and the words "Caution, Radioactive Material" or "Danger, Radioactive Material." The label 
shall also provide sufficient information to permit individuals handling, using, or working in the vicinity of the items or containers to take precautions to avoid or control exposures.

[63 FR 59684, Nov. 4, 1998]

\section{$\$ 835.606$ Exceptions to labeling re- quirements.}

(a) Items and containers may be excepted from the radioactive material labeling requirements of $\$ 835.605$ when:

(1) Used, handled, or stored in areas posted and controlled in accordance with this subpart and sufficient information is provided to permit individuals to take precautions to avoid or control exposures; or

(2) The quantity of radioactive material is less than one tenth of the values specified in appendix $\mathrm{E}$ of this part and less than $0.1 \mathrm{Ci}$; or

(3) Packaged, labeled, and marked in accordance with the regulations of the Department of Transportation or DOE Orders governing radioactive material transportation; or

(4) Inaccessible, or accessible only to individuals authorized to handle or use them, or to work in the vicinity; or

(5) Installed in manufacturing, process, or other equipment, such as reactor components, piping, and tanks; or

(6) The radioactive material consists solely of nuclear weapons or their components.

(b) Radioactive material labels applied to sealed radioactive sources may be excepted from the color specifications of $\S 835.601$ (a).

[63 FR 59684, Nov. 4, 1998, as amended at 72 FR 31927, June 8, 2007]

\section{Subpart H-Records}

\section{\$ 835.701 General provisions.}

(a) Records shall be maintained to document compliance with this part and with radiation protection programs required by $\S 835.101$.

(b) Unless otherwise specified in this subpart, records shall be retained until final disposition is authorized by DOE.

$\S 835.702$ Individual records.

monitoring

(a) Except as authorized by $\S 835.702(\mathrm{~b})$, records shall be maintained to document doses received by all individuals for whom monitoring was conducted and to document doses received during planned special exposures, unplanned doses exceeding the monitoring thresholds of $\S 835.402$, and authorized emergency exposures.

(b) Recording of the non-uniform equivalent dose to the skin is not required if the dose is less than 2 percent of the limit specified for the skin at $\S 835.202(\mathrm{a})(4)$. Recording of internal dose (committed effective dose or committed equivalent dose) is not required for any monitoring result estimated to correspond to an individual receiving less than $0.01 \mathrm{rem}(0.1 \mathrm{mSv})$ committed effective dose. The bioassay or air monitoring result used to make the estimate shall be maintained in accordance with $\$ 835.703(b)$ and the unrecorded internal dose estimated for any individual in a year shall not exceed the applicable monitoring threshold at $\S 835.402(\mathrm{c})$.

(c) The records required by this section shall:

(1) Be sufficient to evaluate compliance with subpart $\mathrm{C}$ of this part;

(2) Be sufficient to provide dose information necessary to complete reports required by subpart I of this part;

(3) Include the results of monitoring used to assess the following quantities for external dose received during the year:

(i) The effective dose from external sources of radiation (equivalent dose to the whole body may be used as effective dose for external exposure);

(ii) The equivalent dose to the lens of the eye;

(iii) The equivalent dose to the skin; and

(iv) The equivalent dose to the extremities.

(4) Include the following information for internal dose resulting from intakes received during the year:

(i) Committed effective dose;

(ii) Committed equivalent dose to any organ or tissue of concern; and

(iii) Identity of radionuclides.

(5) Include the following quantities for the summation of the external and internal dose:

(i) Total effective dose in a year;

(ii) For any organ or tissue assigned an internal dose during the year, the 


\section{Department of Energy}

sum of the equivalent dose to the whole body from external exposures and the committed equivalent dose to that organ or tissue; and

(iii) Cumulative total effective dose.

(6) Include the equivalent dose to the embryo/fetus of a declared pregnant worker.

(d) Documentation of all occupational doses received during the current year, except for doses resulting from planned special exposures conducted in compliance with $\$ 835.204$ and emergency exposures authorized in accordance with $\$ 835.1302(d)$, shall be obtained to demonstrate compliance with $\$ 835.202(\mathrm{a})$. If complete records documenting previous occupational dose during the year cannot be obtained, a written estimate signed by the individual may be accepted to demonstrate compliance.

(e) For radiological workers whose occupational dose is monitored in accordance with $\$ 835.402$, reasonable efforts shall be made to obtain complete records of prior years occupational internal and external doses.

(f) The records specified in this section that are identified with a specific individual shall be readily available to that individual.

(g) Data necessary to allow future verification or reassessment of the recorded doses shall be recorded.

(h) All records required by this section shall be transferred to the DOE upon cessation of activities at the site that could cause exposure to individuals.

[58 FR 65485, Dec. 14, 1993, as amended at 63 FR 59685, Nov. 4, 1998; 72 FR 31927, June 8, 2007]

\$ 835.703 Other monitoring records.

The following information shall be documented and maintained:

(a) Results of monitoring for radiation and radioactive material as required by subparts E and L of this part, except for monitoring required by $\S 835.1102(\mathrm{~d})$;

(b) Results of monitoring used to determine individual occupational dose from external and internal sources;

(c) Results of monitoring for the release and control of material and equipment as required by $\$ 835.1101$; and
$\S 835.801$

(d) Results of maintenance and calibration performed on instruments and equipment as required by $\S 835.401(\mathrm{~b})$.

[58 FR 65485, Dec. 14, 1993, as amended at 63 FR 59685, Nov. 4, 1998]

\section{\$ 835.704 Administrative records.}

(a) Training records shall be maintained, as necessary, to demonstrate compliance with $\$ \S 835.901$.

(b) Actions taken to maintain occupational exposures as low as reasonably achievable, including the actions required for this purpose by $\$ 835.101$, as well as facility design and control actions required by $\S \S 835.1001,835.1002$, and 835.1003, shall be documented.

(c) Records shall be maintained to document the results of internal audits and other reviews of program content and implementation.

(d) Written declarations of pregnancy, including the estimated date of conception, and revocations of declarations of pregnancy shall be maintained.

(e) Changes in equipment, techniques, and procedures used for monitoring shall be documented.

(f) Records shall be maintained as necessary to demonstrate compliance with the requirements of $\$ \S 835.1201$ and 835.1202 for sealed radioactive source control, inventory, and source leak tests.

[58 FR 65485, Dec. 14, 1993, as amended at 63 FR 59685, Nov. 4, 1998]

\section{Subpart I-Reports to Individuals}

$\$ 835.801$ Reports to individuals.

(a) Radiation exposure data for individuals monitored in accordance with $\S 835.402$ shall be reported as specified in this section. The information shall include the data required under $\S 835.702(\mathrm{c})$. Each notification and report shall be in writing and include: the DOE site or facility name, the name of the individual, and the individual's social security number, employee number, or other unique identification number.

(b) Upon the request from an individual terminating employment, records of exposure shall be provided to that individual as soon as the data are available, but not later than 90 days after termination. A written estimate 
$\S 835.901$

of the radiation dose received by that employee based on available information shall be provided at the time of termination, if requested.

(c) Each DOE- or DOE-contractor-operated site or facility shall, on an annual basis, provide a radiation dose report to each individual monitored during the year at that site or facility in accordance with $\S 835.402$.

(d) Detailed information concerning any individual's exposure shall be made available to the individual upon request of that individual, consistent with the provisions of the Privacy Act (5 U.S.C. $552 \mathrm{a}$ ).

(e) When a DOE contractor is required to report to the Department, pursuant to Departmental requirements for occurrence reporting and processing, any exposure of an individual to radiation and/or radioactive material, or planned special exposure in accordance with $\S 835.204(\mathrm{e})$, the contractor shall also provide that individual with a report on his or her exposure data included therein. Such report shall be transmitted at a time not later than the transmittal to the Department.

[58 FR 65485, Dec. 14, 1993, as amended at 63 FR 59685, Nov. 4, 1998]

\section{Subpart J-Radiation Safety Training}

\section{\$835.901 Radiation safety training.}

(a) Each individual shall complete radiation safety training on the topics established at $\S 835.901$ (c) commensurate with the hazards in the area and the required controls:

(1) Before being permitted unescorted access to controlled areas; and

(2) Before receiving occupational dose during access to controlled areas at a DOE site or facility.

(b) Each individual shall demonstrate knowledge of the radiation safety training topics established at $\S 835.901$ (c), commensurate with the hazards in the area and required controls, by successful completion of an examination and performance demonstrations:

(1) Before being permitted unescorted access to radiological areas; and

\section{CFR Ch. III (1-1-08 Edition)}

(2) Before performing unescorted assignments as a radiological worker.

(c) Radiation safety training shall include the following topics, to the extent appropriate to each individual's prior training, work assignments, and degree of exposure to potential radiological hazards:

(1) Risks of exposure to radiation and radioactive materials, including prenatal radiation exposure;

(2) Basic radiological fundamentals and radiation protection concepts;

(3) Physical design features, administrative controls, limits, policies, procedures, alarms, and other measures implemented at the facility to manage doses and maintain doses ALARA, including both routine and emergency actions;

(4) Individual rights and responsibilities as related to implementation of the facility radiation protection program;

(5) Individual responsibilities for implementing ALARA measures required by $\S 835.101$; and

(6) Individual exposure reports that may be requested in accordance with $\S 835.801$.

(d) When an escort is used in lieu of training in accordance with paragraph (a) or (b) of this section, the escort shall:

(1) Have completed radiation safety training, examinations, and performance demonstrations required for entry to the area and performance of the work; and

(2) Ensure that all escorted individuals comply with the documented radiation protection program.

(e) Radiation safety training shall be provided to individuals when there is a significant change to radiation protection policies and procedures that may affect the individual and at intervals not to exceed 24 months. Such training provided for individuals subject to the requirements of $\S 835.901(b)(1)$ and (b)(2) shall include successful completion of an examination.

[63 FR 59685, Nov. 4, 1998] 
Department of Energy

\section{$\S \S 835.902-835.903 \quad$ [Reserved]}

\section{Subpart K-Design and Control}

\$ 835.1001 Design and control.

(a) Measures shall be taken to maintain radiation exposure in controlled areas ALARA through engineered and administrative controls. The primary methods used shall be physical design features (e.g., confinement, ventilation, remote handling, and shielding). Administrative controls shall be employed only as supplemental methods to control radiation exposure.

(b) For specific activities where use of engineered controls is demonstrated to be impractical, administrative controls shall be used to maintain radiation exposures ALARA.

[63 FR 59686, Nov. 4, 1998, as amended at 72 FR 31927, June 8, 2007]

$\$ 835.1002$ Facility design and modifications.

During the design of new facilities or modification of existing facilities, the following objectives shall be adopted:

(a) Optimization methods shall be used to assure that occupational exposure is maintained ALARA in developing and justifying facility design and physical controls.

(b) The design objective for controlling personnel exposure from external sources of radiation in areas of continuous occupational occupancy $(2000$ hours per year) shall be to maintain exposure levels below an average of 0.5 millirem $(5 \mu \mathrm{Sv})$ per hour and as far below this average as is reasonably achievable. The design objectives for exposure rates for potential exposure to a radiological worker where occupancy differs from the above shall be ALARA and shall not exceed 20 percent of the applicable standards in $\$ 835.202$.

(c) Regarding the control of airborne radioactive material, the design objective shall be, under normal conditions, to avoid releases to the workplace atmosphere and in any situation, to control the inhalation of such material by workers to levels that are ALARA; confinement and ventilation shall normally be used.

(d) The design or modification of a facility and the selection of materials
$\S 835.1101$

shall include features that facilitate operations, maintenance, decontamination, and decommissioning.

[58 FR 65485, Dec. 14, 1993, as amended at 63 FR 59686, Nov. 4, 1998; 72 FR 31927, June 8, 2007]

\section{\$835.1003 Workplace controls.}

During routine operations, the combination of engineered and administrative controls shall provide that:

(a) The anticipated occupational dose to general employees shall not exceed the limits established at $\$ 835.202$; and

(b) The ALARA process is utilized for personnel exposures to ionizing radiation.

[63 FR 59686, Nov. 4, 1998, as amended at 72 FR 31927, June 8, 2007]

\section{Subpart L-Radioactive Contamination Control}

SoURCE: 63 FR 59686, Nov. 4, 1998, unless otherwise noted.

$\S 835.1101$ Control of material and equipment.

(a) Except as provided in paragraphs (b) and (c) of this section, material and equipment in contamination areas, high contamination areas, and airborne radioactivity areas shall not be released to a controlled area if:

(1) Removable surface contamination levels on accessible surfaces exceed the removable surface contamination values specified in appendix D of this part; or

(2) Prior use suggests that the removable surface contamination levels on inaccessible surfaces are likely to exceed the removable surface contamination values specified in appendix $\mathrm{D}$ of this part.

(b) Material and equipment exceeding the removable surface contamination values specified in appendix $D$ of this part may be conditionally released for movement on-site from one radiological area for immediate placement in another radiological area only if appropriate monitoring is performed and appropriate controls for the movement are established and exercised.

(c) Material and equipment with fixed contamination levels that exceed 
$\S 835.1102$

the total contamination values specified in appendix D of this part may be released for use in controlled areas outside of radiological areas only under the following conditions:

(1) Removable surface contamination levels are below the removable surface contamination values specified in appendix D of this part; and

(2) The material or equipment is routinely monitored and clearly marked or labeled to alert personnel of the contaminated status.

\section{$\$ 835.1102$ Control of areas.}

(a) Appropriate controls shall be maintained and verified which prevent the inadvertent transfer of removable contamination to locations outside of radiological areas under normal operating conditions.

(b) Any area in which contamination levels exceed the values specified in appendix $\mathrm{D}$ of this part shall be controlled in a manner commensurate with the physical and chemical characteristics of the contaminant, the radionuclides present, and the fixed and removable surface contamination levels.

(c) Areas accessible to individuals where the measured total surface contamination levels exceed, but the removable surface contamination levels are less than, corresponding surface contamination values specified in appendix $\mathrm{D}$ of this part, shall be controlled as follows when located outside of radiological areas:

(1) The area shall be routinely monitored to ensure the removable surface contamination level remains below the removable surface contamination values specified in appendix D of this part; and

(2) The area shall be conspicuously marked to warn individuals of the contaminated status.

(d) Individuals exiting contamination, high contamination, or airborne radioactivity areas shall be monitored, as appropriate, for the presence of surface contamination.

(e) Protective clothing shall be required for entry to areas in which removable contamination exists at levels exceeding the removable surface contamination values specified in appendix D of this part.
10 CFR Ch. III (1-1-08 Edition)

\section{Subpart M-Sealed Radioactive Source Control}

SOURCE: 63 FR 59686, Nov. 4, 1998, unless otherwise noted.

\section{$\S 835.1201$ Sealed radioactive source} control.

Sealed radioactive sources shall be used, handled, and stored in a manner commensurate with the hazards associated with operations involving the sources.

$\$ 835.1202$ Accountable sealed radioactive sources.

(a) Each accountable sealed radioactive source shall be inventoried at intervals not to exceed six months. This inventory shall:

(1) Establish the physical location of each accountable sealed radioactive source;

(2) Verify the presence and adequacy of associated postings and labels; and

(3) Establish the adequacy of storage locations, containers, and devices.

(b) Except for sealed radioactive sources consisting solely of gaseous radioactive material or tritium, each accountable sealed radioactive source shall be subject to a source leak test upon receipt, when damage is suspected, and at intervals not to exceed six months. Source leak tests shall be capable of detecting radioactive material leakage equal to or exceeding 0.005 $\mu \mathrm{Ci}$.

(c) Notwithstanding the requirements of paragraph (b) of this section, an accountable sealed radioactive source is not subject to periodic source leak testing if that source has been removed from service. Such sources shall be stored in a controlled location, subject to periodic inventory as required by paragraph (a) of this section, and subject to source leak testing prior to being returned to service.

(d) Notwithstanding the requirements of paragraphs (a) and (b) of this section, an accountable sealed radioactive source is not subject to periodic inventory and source leak testing if that source is located in an area that is unsafe for human entry or otherwise inaccessible.

(e) An accountable sealed radioactive source found to be leaking radioactive 


\section{Department of Energy}

material shall be controlled in a manner that minimizes the spread of radioactive contamination.

[63 FR 59686, Nov. 4, 1998, as amended at 72 FR 31927, June 8, 2007]

\section{Subpart N-Emergency Exposure Situations}

\section{§ 835.1301 General provisions.}

(a) A general employee whose occupational dose has exceeded the numerical value of any of the limits specified in $\$ 835.202$ as a result of an authorized emergency exposure may be permitted to return to work in radiological areas during the current year providing that all of the following conditions are met:

(1) Approval is first obtained from the contractor management and the Head of the responsible DOE field organization;

(2) The individual receives counseling from radiological protection and medical personnel regarding the consequences of receiving additional occupational exposure during the year; and

(3) The affected employee agrees to return to radiological work.

(b) All doses exceeding the limits specified in $\S 835.202$ shall be recorded in the affected individual's occupational dose record.

(c) When the conditions under which a dose was received in excess of the limits specified in $\$ 835.202$, except those received in accordance with $\$ 835.204$, have been eliminated, operating management shall notify the Head of the responsible DOE field organization.

(d) Operations which have been suspended as a result of a dose in excess of the limits specified in $\$ 835.202$, except those received in accordance with $\S 835.204$, may be resumed only with the approval of DOE.

[58 FR 65485, Dec. 14, 1993, as amended at 63 FR 59687, Nov. 4, 1998; 72 FR 31927, June 8, 2007]

$\$$ 835.1302 Emergency exposure situations.

(a) The risk of injury to those individuals involved in rescue and recovery operations shall be minimized.

\section{Pt. 835, App. A}

(b) Operating management shall weigh actual and potential risks against the benefits to be gained.

(c) No individual shall be required to perform a rescue action that might involve substantial personal risk.

(d) Each individual authorized to perform emergency actions likely to result in occupational doses exceeding the values of the limits provided at $\$ 835.202$ (a) shall be trained in accordance with $\S 835.901(\mathrm{~b})$ and briefed beforehand on the known or anticipated hazards to which the individual will be subjected.

[58 FR 65485, Dec. 14, 1993, as amended at 63 FR 59687, Nov. 4, 1998]

\section{$\S 835.1303$ [Reserved]}

\$ 835.1304 Nuclear accident dosimetry.

(a) Installations possessing sufficient quantities of fissile material to potentially constitute a critical mass, such that the excessive exposure of individuals to radiation from a nuclear accident is possible, shall provide nuclear accident dosimetry for those individuals.

(b) Nuclear accident dosimetry shall include the following:

(1) A method to conduct initial screening of individuals involved in a nuclear accident to determine whether significant exposures to radiation occurred;

(2) Methods and equipment for analysis of biological materials;

(3) A system of fixed nuclear accident dosimeter units; and

(4) Personal nuclear accident dosimeters.

[58 FR 65485, Dec. 14, 1993, as amended at 63 FR 59687, Nov. 4, 1998]

APPENDIX A TO PART 835-DERIVED AIR CONCENTRATIONS (DAC) FOR CONTROLLING RADIATION EXPOSURE TO WORKERS AT DOE FACILITIES

The data presented in appendix $\mathrm{A}$ are to be used for controlling individual internal doses in accordance with $\$ 835.209$, identifying the need for air monitoring in accordance with $\$ 835.403$, and identifying and posting airborne radioactivity areas in accordance with $\S 835.603(\mathrm{~d})$

The DAC values are given for individual radionuclides. For known mixtures of radionuclides, determine the sum of the ratio of the observed concentration of a particular 


\section{Pt. 835, App. A}

radionuclide and its corresponding DAC for all radionuclides in the mixture. If this sum exceeds unity (1), then the DAC has been exceeded. For unknown radionuclides, the most restrictive DAC (lowest value) for those isotopes not known to be absent shall be used. For any single radionuclide not listed in appendix A with decay mode other than alpha emission or spontaneous fission and with radioactive half-life greater than two hours, the DAC value shall be $4 \mathrm{E}-11 \mu \mathrm{Ci} / \mathrm{mL}(1 \mathrm{~Bq}$ $\mathrm{m}^{3}$ ). For any single radionuclide not listed in appendix A that decays by alpha emission or spontaneous fission the DAC value shall be 2 E-13 $\mu \mathrm{Ci} / \mathrm{mL}\left(8 \mathrm{E}-03 \mathrm{~Bq} / \mathrm{m}^{3}\right)$.

The DACs for limiting radiation exposures through inhalation of radionuclides by workers are listed in this appendix. The values are based on either a stochastic (committed effective dose) dose limit of 5 rems $(0.05 \mathrm{~Sv})$ or a deterministic (organ or tissue) dose limit of 50 rems $(0.5 \mathrm{~Sv})$ per year, whichever is more limiting.

NoTE: the 15 rems $(0.15 \mathrm{~Sv})$ dose limit for the lens of the eye does not appear as a critical organ dose limit.

\begin{tabular}{|c|c|c|c|c|c|c|c|}
\hline \multirow{3}{*}{ Radionuclide } & \multirow{2}{*}{\multicolumn{3}{|c|}{$\frac{\text { Absorption type }^{3}}{\mu \mathrm{Ci} / \mathrm{mL}}$}} & \multicolumn{3}{|c|}{ Absorption type ${ }^{3}$} & \multirow{3}{*}{$\begin{array}{c}\begin{array}{c}\text { Stochastic or } \\
\text { organ or tis- }^{\text {orge }} \text { sue }^{1}\end{array} \\
(\mathrm{~F} / \mathrm{M} / \mathrm{S})\end{array}$} \\
\hline & & & & \multicolumn{3}{|c|}{$\mathrm{Bq} / \mathrm{m}^{3}$} & \\
\hline & $\mathrm{F}$ & M & $S$ & $\mathrm{~F}$ & M & $S$ & \\
\hline H-3 (Water) ${ }^{2} \ldots$ & $2 E-05$ & $2 E-05$ & $2 E-05$ & $7 \mathrm{E}+05$ & $7 E+05$ & $7 \mathrm{E}+05$ & $\mathrm{St} / \mathrm{St} / \mathrm{St}$ \\
\hline $\mathrm{H}-3$ (Elemental) ${ }^{2}$ & $2 \mathrm{E}-01$ & $2 E-01$ & $2 \mathrm{E}-01$ & $9 \mathrm{E}+09$ & $9 \mathrm{E}+09$ & $9 \mathrm{E}+09$ & $\mathrm{St} / \mathrm{St} / \mathrm{St}$ \\
\hline STCs (Insoluble) 4 & $1 E-05$ & $6 E-06$ & $2 E-06$ & $3 \mathrm{E}+05$ & $2 E+05$ & $8 \mathrm{E}+04$ & $\mathrm{St} / \mathrm{St} / \mathrm{St}$ \\
\hline STCs (Soluble) ... & $1 E-05$ & $1 E-05$ & $1 \mathrm{E}-05$ & $5 \mathrm{E}+05$ & $5 \mathrm{E}+05$ & $5 \mathrm{E}+05$ & $\mathrm{St} / \mathrm{St} / \mathrm{St}$ \\
\hline $\mathrm{Be}-7$ & - & $1 E-05$ & $1 \mathrm{E}-05$ & - & $4 \mathrm{E}+05$ & $4 \mathrm{E}+05$ & $/ \mathrm{St} / \mathrm{St}$ \\
\hline ...……........ & - & $8 E-08$ & $2 E-08$ & - & $3 E+03$ & $1 E+03$ & $/ \mathrm{St} / \mathrm{St}$ \\
\hline C-11 (Vapor) $)^{2} \ldots$. & - & $1 E-04$ & - & - & $6 \mathrm{E}+06$ & - & $/ \mathrm{St} /$ \\
\hline $\mathrm{C}-11(\mathrm{CO})^{2} \ldots \ldots \ldots$ & $4 E-04$ & $4 E-04$ & $4 E-04$ & $1 \mathrm{E}+07$ & $1 \mathrm{E}+07$ & $1 E+07$ & $\mathrm{St} / \mathrm{St} / \mathrm{St}$ \\
\hline $\mathrm{C}-11\left(\mathrm{CO}_{2}\right)^{2} \ldots \ldots$. & $2 E-04$ & $2 E-04$ & $2 E-04$ & $9 \mathrm{E}+06$ & $9 \mathrm{E}+06$ & $9 \mathrm{E}+06$ & $\mathrm{St} / \mathrm{St} / \mathrm{St}$ \\
\hline C-14 (Vapor) ${ }^{2} \ldots .$. & - & $9 \bar{E}-07$ & - & - & $3 E+04$ & - & $/ \mathrm{St} /$ \\
\hline $\mathrm{C}-14(\mathrm{CO})^{2} \ldots \ldots \ldots$ & $7 E-04$ & $7 E-04$ & $7 E-04$ & $2 \mathrm{E}+07$ & $2 \mathrm{E}+07$ & $2 \mathrm{E}+07$ & $\mathrm{St} / \mathrm{St} / \mathrm{St}$ \\
\hline $\mathrm{C}-14\left(\mathrm{CO}_{2}\right)^{2} \ldots \ldots$ & $8 E-05$ & $8 E-05$ & $8 E-05$ & $3 E+06$ & $3 E+06$ & $3 E+06$ & $\mathrm{St} / \mathrm{St} / \mathrm{St}$ \\
\hline F-18 …… & $4 E-06$ & $3 E-06$ & $3 E-06$ & $1 \mathrm{E}+05$ & $1 \mathrm{E}+05$ & $1 \mathrm{E}+05$ & $\mathrm{ET} / \mathrm{ET} / \mathrm{ET}$ \\
\hline $\mathrm{Na}-22$..................... & $2 E-07$ & - & - & $1 \mathrm{E}+04$ & - & - & $\mathrm{E} / 1$ \\
\hline $\mathrm{Na}-24$ & $4 E-07$ & - & - & $1 \mathrm{E}+04$ & - & - & $\mathrm{ET} / /$ \\
\hline $\mathrm{Mg}-28 \ldots \ldots \ldots \ldots \ldots \ldots \ldots$ & $3 E-07$ & $3 E-07$ & - & $1 \mathrm{E}+04$ & $1 \mathrm{E}+04$ & - & $\mathrm{ET} / \mathrm{St} /$ \\
\hline Al-26 & $4 E-08$ & $4 \bar{E}-08$ & - & $1 \mathrm{E}+03$ & $1 \mathrm{E}+03$ & - & $\mathrm{St} / \mathrm{St} /$ \\
\hline Si-31 ………........ & $9 E-06$ & $5 E-06$ & $5 E-06$ & $3 \mathrm{E}+05$ & $1 \mathrm{E}+05$ & $1 \mathrm{E}+05$ & $E T / S t / S t$ \\
\hline Si-32 …… & $1 E-07$ & $5 E-08$ & $1 \mathrm{E}-08$ & $5 E+03$ & $2 E+03$ & $3 E+02$ & $\mathrm{St} / \mathrm{St} / \mathrm{St}$ \\
\hline P-32 ............... & $5 E-07$ & $1 \bar{E}-07$ & - & $1 \mathrm{E}+04$ & $7 \mathrm{E}+03$ & - & $\mathrm{St} / \mathrm{St} /$ \\
\hline P-33 … & $4 E-06$ & $4 \mathrm{E}-07$ & - & $1 E+05$ & $1 \mathrm{E}+04$ & - & $\mathrm{St} / \mathrm{St} /$ \\
\hline S-35 (Vapor) ........ & - & $4 \bar{E}-06$ & - & - & $1 \mathrm{E}+05$ & - & $/ \mathrm{St} /$ \\
\hline S-35 … & $7 E-06$ & $5 E-07$ & - & $2 E+05$ & $1 \mathrm{E}+04$ & - & $\mathrm{St} / \mathrm{St} /$ \\
\hline $\mathrm{Cl}-36$ & $1 \bar{E}-06$ & $1 \bar{E}-07$ & - & $4 \mathrm{E}+04$ & $4 \mathrm{E}+03$ & - & $\mathrm{St} / \mathrm{St} /$ \\
\hline $\mathrm{Cl}-38$ & $7 E-06$ & $5 E-06$ & - & $2 E+05$ & $2 E+05$ & - & $\mathrm{ET} / \mathrm{ET} /$ \\
\hline $\mathrm{Cl}-39$ & $2 E-06$ & $4 E-06$ & - & $1 \mathrm{E}+05$ & $1 \mathrm{E}+05$ & - & $\mathrm{ET} / \mathrm{ET} /$ \\
\hline K-40 …….............. & $1 \mathrm{E}-07$ & - & - & $6 \mathrm{E}+03$ & - & - & $\mathrm{St} / 1$ \\
\hline K-42 …… & $2 E-06$ & - & - & $1 \mathrm{E}+05$ & _- & - & E/ / \\
\hline K-43 …… & $9 E-07$ & - & - & $3 E+04$ & - & - & $\mathrm{ET} / /$ \\
\hline K-44 …… & $8 E-06$ & - & - & $2 \mathrm{E}+05$ & _- & - & ET/ / \\
\hline K-45 ……… & $9 E-06$ & - & - & $3 E+05$ & - & - & $\mathrm{ET} / /$ \\
\hline $\mathrm{Ca}-41 \ldots \ldots \ldots \ldots \ldots$ & - & $2 E-06$ & - & - & $8 \mathrm{E}+04$ & - & /BS/ \\
\hline Сa-45 ……............ & - & $2 E-07$ & - & - & $9 \mathrm{E}+03$ & - & /St/ \\
\hline $\mathrm{Ca}-47 \ldots \ldots \ldots$ & - & $2 E-07$ & - & - & $9 \mathrm{E}+03$ & - & /St/ \\
\hline Sc-43 …….............. & _- & - & $2 E-06$ & _- & - & $7 E+04$ & $/ / \mathrm{ET}$ \\
\hline Sc-44m ……........... & - & - & $2 E-07$ & - & - & $1 E+04$ & $/ / \mathrm{St}$ \\
\hline Sc-44 ………........ & - & - & $1 E-06$ & - & - & $4 \mathrm{E}+04$ & $/ /$ IET \\
\hline Sc-46 & - & - & $1 \mathrm{E}-07$ & - & - & $4 \mathrm{E}+03$ & $/$ /St \\
\hline 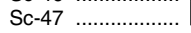 & - & - & $7 \mathrm{E}-07$ & - & - & $2 E+04$ & $/ / \mathrm{St}$ \\
\hline
\end{tabular}

The columns in this appendix contain the following information: (1) Radionuclide; (2) inhaled air DAC for type $\mathrm{F}$ (fast), type $\mathrm{M}$ (moderate), and type $\mathrm{S}$ (slow) materials in units of $\mu \mathrm{Ci} / \mathrm{mL}$; (3) inhaled air DAC for type $\mathrm{F}$ (fast), type $\mathrm{M}$ (moderate), and type $\mathrm{s}$ (slow) materials in units of $\mathrm{Bq} / \mathrm{m}^{3}$; (4) an indication of whether or not the DAC for each class is controlled by the stochastic (effective dose) or deterministic (organ or tissue) dose. The absorption types (F, M, and $\mathrm{S}$ ) have been established to describe the absorption type of the materials from the respiratory tract into the blood. The range of half-times for the absorption types correspond to: Type F, $100 \%$ at 10 minutes; Type M, $10 \%$ at 10 minutes and $90 \%$ at 140 days and Type $\mathrm{S} 0.1 \%$ at 10 minutes and $99.9 \%$ at 7000 days. The DACs are listed by radionuclide, in order of increasing atomic mass, and are based on the assumption that the particle size distribution of 5 micrometers AMAD is used. For situations where the particle size distribution is known to differ significantly from 5 micrometers AMAD, appropriate corrections may be made to both the priate corrections may be made to to workers and the DACs. 
Department of Energy

Pt. 835, App. A

\begin{tabular}{|c|c|c|c|c|c|c|c|}
\hline \multirow{3}{*}{ Radionuclide } & \multicolumn{3}{|c|}{ Absorption type ${ }^{3}$} & \multicolumn{3}{|c|}{ Absorption type ${ }^{3}$} & \multirow{3}{*}{$\begin{array}{c}\begin{array}{c}\text { Stochastic or } \\
\text { organ or tis- } \\
\text { sue }^{1}\end{array} \\
(\mathrm{~F} / \mathrm{M} / \mathrm{S})\end{array}$} \\
\hline & \multicolumn{3}{|c|}{$\mu \mathrm{Ci} / \mathrm{mL}$} & \multicolumn{3}{|c|}{$\mathrm{Bq} / \mathrm{m}^{3}$} & \\
\hline & $\mathrm{F}$ & M & $S$ & $\mathrm{~F}$ & M & s & \\
\hline Sc-48 & - & - & $2 E-07$ & - & - & $1 \mathrm{E}+04$ & / /ET \\
\hline Sc-49 ……............... & - & - & $8 E-06$ & - & - & $3 \mathrm{E}+05$ & $/ / E T$ \\
\hline Ti-44 ........................ & $7 E-09$ & $2 E-08$ & $9 E-09$ & $2 \mathrm{E}+02$ & $7 \mathrm{E}+02$ & $3 \mathrm{E}+02$ & $\mathrm{St} / \mathrm{St} / \mathrm{St}$ \\
\hline Ti-45 ...................... & $3 E-06$ & $2 E-06$ & $2 E-06$ & $1 \mathrm{E}+05$ & $1 \mathrm{E}+05$ & $1 \mathrm{E}+05$ & $\mathrm{ET} / \mathrm{ET} / \mathrm{ET}$ \\
\hline V-47 ……...................... & $8 E-06$ & $6 \mathrm{E}-06$ & - & $3 \mathrm{E}+05$ & $2 \mathrm{E}+05$ & - & $\mathrm{ET} / \mathrm{ET} /$ \\
\hline V-48 & $2 \mathrm{E}-07$ & $2 E-07$ & - & $9 \mathrm{E}+03$ & $7 \mathrm{E}+03$ & - & $\mathrm{ET} / \mathrm{St} /$ \\
\hline 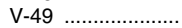 & $1 E-05$ & $2 E-05$ & - & $7 \mathrm{E}+05$ & $9 \mathrm{E}+05$ & - & $\mathrm{BS} / \mathrm{St} /$ \\
\hline Cr-48 ......................... & $2 E-06$ & $2 E-06$ & $2 E-06$ & $8 \mathrm{E}+04$ & $8 \mathrm{E}+04$ & $8 \mathrm{E}+04$ & $\mathrm{ET} / \mathrm{ET} / \mathrm{ET}$ \\
\hline Cr-49 …................ & $7 E-06$ & $5 E-06$ & $5 E-06$ & $2 \mathrm{E}+05$ & $2 \mathrm{E}+05$ & $2 \mathrm{E}+05$ & $\mathrm{ET} / \mathrm{ET} / \mathrm{ET}$ \\
\hline Cr-51 … & $1 E-05$ & $1 \mathrm{E}-05$ & $1 \mathrm{E}-05$ & $6 \mathrm{E}+05$ & $6 \mathrm{E}+05$ & $5 \mathrm{E}+05$ & $\mathrm{St} / \mathrm{St} / \mathrm{St}$ \\
\hline Mn-51 ..................... & $7 E-06$ & $5 E-06$ & - & $2 E+05$ & $2 \mathrm{E}+05$ & - & $\mathrm{ET} / \mathrm{ET} /$ \\
\hline Mn-52m ................... & $7 E-06$ & $5 E-06$ & - & $2 \mathrm{E}+05$ & $2 \mathrm{E}+05$ & - & $\mathrm{ET} / \mathrm{ET} /$ \\
\hline Mn-52 ..................... & $2 E-07$ & $2 E-07$ & - & $8 \mathrm{E}+03$ & $8 \mathrm{E}+03$ & - & $\mathrm{ET} / \mathrm{ET} /$ \\
\hline Mn-53 ........................ & $5 E-06$ & $1 \mathrm{E}-05$ & - & $2 \mathrm{E}+05$ & $5 \mathrm{E}+05$ & - & $\mathrm{BS} / \mathrm{St} /$ \\
\hline Mn-54 ..................... & $5 E-07$ & $4 E-07$ & - & $1 \mathrm{E}+04$ & $1 \mathrm{E}+04$ & - & $\mathrm{St} / \mathrm{St} /$ \\
\hline $\mathrm{Mn}-56$ & $2 E-06$ & $2 E-06$ & - & $9 \mathrm{E}+04$ & $8 \mathrm{E}+04$ & - & $\mathrm{ET} / \mathrm{ET} /$ \\
\hline Fe-52 …................. & $6 \mathrm{E}-07$ & $5 E-07$ & - & $2 E+04$ & $2 \mathrm{E}+04$ & - & $\mathrm{ET} / \mathrm{E} /$ \\
\hline Fe-55 ….................. & $6 \mathrm{E}-07$ & $1 \mathrm{E}-06$ & - & $2 \mathrm{E}+04$ & $6 \mathrm{E}+04$ & - & $\mathrm{St} / \mathrm{St} /$ \\
\hline Fe-59 ……............. & $1 E-07$ & $1 \mathrm{E}-07$ & - & $6 \mathrm{E}+03$ & $6 \mathrm{E}+03$ & - & $\mathrm{St} / \mathrm{St} /$ \\
\hline Fe-60 …...................... & $1 E-09$ & $4 E-09$ & - & $6 \mathrm{E}+01$ & $1 \mathrm{E}+02$ & - & $\mathrm{St} / \mathrm{St} /$ \\
\hline Co-55 ……............... & - & $5 E-07$ & $5 E-07$ & - & $2 \mathrm{E}+04$ & $2 \mathrm{E}+04$ & /ET/ET \\
\hline Co-56 ……............... & - & $1 \mathrm{E}-07$ & $1 \mathrm{E}-07$ & - & $5 \mathrm{E}+03$ & $4 \mathrm{E}+03$ & $/ \mathrm{St} / \mathrm{St}$ \\
\hline Co-57 …….............. & - & $1 E-06$ & $9 \mathrm{E}-07$ & - & $5 \mathrm{E}+04$ & $3 \mathrm{E}+04$ & $/ \mathrm{St} / \mathrm{St}$ \\
\hline Co-58m ................. & - & $3 E-05$ & $3 E-05$ & - & $1 \mathrm{E}+06$ & $1 \mathrm{E}+06$ & $/ \mathrm{St} / \mathrm{St}$ \\
\hline Co-58 ……............... & - & $4 E-07$ & $3 E-07$ & - & $1 \mathrm{E}+04$ & $1 \mathrm{E}+04$ & $/ \mathrm{St} / \mathrm{St}$ \\
\hline Co-60m ……............ & - & $4 E-04$ & $4 E-04$ & - & $1 \mathrm{E}+07$ & $1 \mathrm{E}+07$ & $/ \mathrm{St} / \mathrm{St}$ \\
\hline Co-60 ……............... & - & $7 E-08$ & $3 E-08$ & - & $2 \mathrm{E}+03$ & $1 \mathrm{E}+03$ & $/ \mathrm{St} / \mathrm{St}$ \\
\hline Co-61 ........................ & - & $6 \mathrm{E}-06$ & $6 E-06$ & - & $2 \mathrm{E}+05$ & $2 \mathrm{E}+05$ & /ET/ET \\
\hline Co-62m ……........... & - & $7 E-06$ & $6 E-06$ & - & $2 \mathrm{E}+05$ & $2 \mathrm{E}+05$ & /ET/ET \\
\hline Ni-56 (Inorg) ........ & $4 E-07$ & $4 \mathrm{E}-07$ & - & $1 \mathrm{E}+04$ & $1 \mathrm{E}+04$ & - & $\mathrm{ET} / \mathrm{ET} /$ \\
\hline Ni-56 (Carbonyl) & - & $4 \mathrm{E}-07$ & - & - & $1 \mathrm{E}+04$ & - & $/ \mathrm{St} /$ \\
\hline Ni-57 (Inorg) ........ & $5 E-07$ & $5 E-07$ & - & $2 \mathrm{E}+04$ & $2 \mathrm{E}+04$ & - & $\mathrm{ET} / \mathrm{ET} /$ \\
\hline $\mathrm{Ni}-57$ (Carbonyl) & - & $7 E-07$ & - & - & $2 \mathrm{E}+04$ & - & /ET/ \\
\hline Ni-59 (Inorg) ........ & $2 E-06$ & $5 E-06$ & - & $9 \mathrm{E}+04$ & $2 \mathrm{E}+05$ & - & $\mathrm{St} / \mathrm{St} /$ \\
\hline Ni-59 (Carbonyl) & - & $6 \mathrm{E}-07$ & - & - & $2 \mathrm{E}+04$ & - & /St/ \\
\hline Ni-63 (Inorg) ........ & $1 E-06$ & $1 \mathrm{E}-06$ & - & $4 \mathrm{E}+04$ & $6 \mathrm{E}+04$ & - & $\mathrm{St} / \mathrm{St} /$ \\
\hline Ni-63 (Carbonyl) & - & $2 E-07$ & - & - & $1 \mathrm{E}+04$ & - & $/ \mathrm{St} /$ \\
\hline $\mathrm{Ni}-65$ (Inorg) ...... & $5 E-06$ & $4 E-06$ & - & $1 \mathrm{E}+05$ & $1 \mathrm{E}+05$ & - & $\mathrm{ET} / \mathrm{ET} /$ \\
\hline $\mathrm{Ni}-65$ (Carbonyl) & - & $8 E-07$ & - & - & $3 \mathrm{E}+04$ & - & /ET/ \\
\hline Ni-66 (Inorg) ........ & $7 E-07$ & $2 E-07$ & - & $2 \mathrm{E}+04$ & $1 \mathrm{E}+04$ & - & $\mathrm{St} / \mathrm{St} /$ \\
\hline Ni-66 (Carbonyl) & - & $2 E-07$ & - & - & $1 \mathrm{E}+04$ & - & /ET/ \\
\hline Cu-60 .................... & $5 E-06$ & $4 E-06$ & $4 E-06$ & $1 \mathrm{E}+05$ & $1 \mathrm{E}+05$ & $1 \mathrm{E}+05$ & ET/ET/ET \\
\hline Cu-61 ....................... & $3 E-06$ & $3 E-06$ & $3 E-06$ & $1 \mathrm{E}+05$ & $1 \mathrm{E}+05$ & $1 \mathrm{E}+05$ & ET/ET/ET \\
\hline Cu-64 ……............ & $4 \mathrm{E}-06$ & $3 E-06$ & $3 E-06$ & $1 \mathrm{E}+05$ & $1 \mathrm{E}+05$ & $1 \mathrm{E}+05$ & $\mathrm{ET} / \mathrm{E} / \mathrm{E}$ \\
\hline Cu-67 ...................... & $2 E-06$ & $1 E-06$ & $9 \mathrm{E}-07$ & $8 \mathrm{E}+04$ & $3 \mathrm{E}+04$ & $3 \mathrm{E}+04$ & $E T / S t / S t$ \\
\hline Zn-62 …................... & - & - & $8 E-07$ & - & - & $3 \mathrm{E}+04$ & $/ / \mathrm{St}$ \\
\hline Zn-63 …….............. & - & - & $5 E-06$ & - & - & $2 \mathrm{E}+05$ & $/ / \mathrm{ET}$ \\
\hline Zn-65 ….................... & - & - & $2 E-07$ & - & - & $7 \mathrm{E}+03$ & $/ / \mathrm{St}$ \\
\hline $\mathrm{Zn}-69 \mathrm{~m}$ & - & - & $1 E-06$ & - & - & $6 \mathrm{E}+04$ & $/ / \mathrm{St}$ \\
\hline Zn-69 & - & - & $7 E-06$ & - & - & $2 \mathrm{E}+05$ & $/ / \mathrm{ET}$ \\
\hline $\mathrm{Zn}-71 \mathrm{~m}$ & - & - & $1 E-06$ & - & - & $5 \mathrm{E}+04$ & $/ /$ /ET \\
\hline Zn-72 ….................. & - & - & $3 E-07$ & - & - & $1 \mathrm{E}+04$ & $/ / \mathrm{St}$ \\
\hline Ga-65 …................. & $1 E-05$ & $9 E-06$ & - & $4 \mathrm{E}+05$ & $3 \mathrm{E}+05$ & - & $\mathrm{ET} / \mathrm{ET} /$ \\
\hline Ga-66 ....................... & $8 \mathrm{E}-07$ & $7 E-07$ & - & $3 E+04$ & $2 \mathrm{E}+04$ & - & $\mathrm{ET} / \mathrm{St} /$ \\
\hline Ga-67 ..................... & $3 E-06$ & $2 E-06$ & - & $1 \mathrm{E}+05$ & $7 \mathrm{E}+04$ & - & $\mathrm{ET} / \mathrm{St} /$ \\
\hline Ga-68 ……............. & $6 \mathrm{E}-06$ & $4 E-06$ & - & $2 \mathrm{E}+05$ & $1 \mathrm{E}+05$ & - & $\mathrm{ET} / \mathrm{ET} /$ \\
\hline Ga-70 ........ & $1 E-05$ & $1 E-05$ & - & $6 \mathrm{E}+05$ & $4 \mathrm{E}+05$ & - & $\mathrm{ET} / \mathrm{ET} /$ \\
\hline Ga-72 ……............. & $5 E-07$ & $5 E-07$ & - & $2 E+04$ & $2 \mathrm{E}+04$ & - & ET/ET/ \\
\hline Ga-73 ....................... & $4 \mathrm{E}-06$ & $2 E-06$ & - & $1 \mathrm{E}+05$ & $1 \mathrm{E}+05$ & - & $\mathrm{ET} / \mathrm{St} /$ \\
\hline Ge-66 ............ & $2 E-06$ & $2 E-06$ & - & $9 \mathrm{E}+04$ & $9 \mathrm{E}+04$ & - & ET/ET/ \\
\hline Ge-67 ….................. & $1 E-05$ & $7 E-06$ & - & $3 \mathrm{E}+05$ & $2 \mathrm{E}+05$ & - & $\mathrm{ET} / \mathrm{ET} /$ \\
\hline Ge-68 ……............. & $6 \mathrm{E}-07$ & $7 E-08$ & - & $2 \mathrm{E}+04$ & $2 \mathrm{E}+03$ & - & $\mathrm{ET} / \mathrm{St} /$ \\
\hline Ge-69 ......... & $1 E-06$ & $1 \mathrm{E}-06$ & - & $3 E+04$ & $3 E+04$ & - & $\mathrm{ET} / \mathrm{ET} /$ \\
\hline Ge-71 ....................... & $5 E-05$ & $5 E-05$ & - & $2 E+06$ & $1 \mathrm{E}+06$ & - & ET/E/ \\
\hline Ge-75 ........... & $1 E-05$ & $7 E-06$ & - & $4 \mathrm{E}+05$ & $2 \mathrm{E}+05$ & - & $\mathrm{ET} / \mathrm{ET} /$ \\
\hline Ge-77 …................. & $1 E-06$ & $1 \mathrm{E}-06$ & - & $4 \mathrm{E}+04$ & $4 \mathrm{E}+04$ & - & $\mathrm{ET} / \mathrm{ET} /$ \\
\hline Ge-78 & $3 E-06$ & $3 E-06$ & - & $1 \mathrm{E}+05$ & $1 \mathrm{E}+05$ & - & ET/ET/ \\
\hline 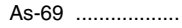 & - & $9 E-06$ & - & - & $3 \mathrm{E}+05$ & - & /ET/ \\
\hline As-70 & - & $2 E-06$ & - & - & $8 \mathrm{E}+04$ & - & /ET/ \\
\hline As-71 ............... & - & $1 E-06$ & - & - & $4 \mathrm{E}+04$ & - & $/ \mathrm{St} /$ \\
\hline As-72 …................. & - & $4 E-07$ & - & - & $1 \mathrm{E}+04$ & - & /St/ \\
\hline
\end{tabular}


Pt. 835, App. A

10 CFR Ch. III (1-1-08 Edition)

\begin{tabular}{|c|c|c|c|c|c|c|c|}
\hline \multirow{3}{*}{ Radionuclide } & \multicolumn{3}{|c|}{ Absorption type ${ }^{3}$} & \multicolumn{3}{|c|}{ Absorption type ${ }^{3}$} & \multirow{2}{*}{$\begin{array}{l}\text { Stochastic or } \\
\text { organ or tis- } \\
\text { sue } 1\end{array}$} \\
\hline & \multicolumn{3}{|c|}{$\mu \mathrm{Ci} / \mathrm{mL}$} & \multicolumn{3}{|c|}{$\mathrm{Bq} / \mathrm{m}^{3}$} & \\
\hline & $\mathrm{F}$ & M & $S$ & $\mathrm{~F}$ & M & s & $(\mathrm{F} / \mathrm{M} / \mathrm{S})$ \\
\hline As-73 ...................... & - & $8 E-07$ & - & - & $3 E+04$ & - & $/ \mathrm{St} /$ \\
\hline As-74 …................ & - & $3 E-07$ & - & - & $1 \mathrm{E}+04$ & - & $/ \mathrm{St} /$ \\
\hline As-76 …................ & - & $6 \mathrm{E}-07$ & - & - & $2 \mathrm{E}+04$ & - & $/ \mathrm{St} /$ \\
\hline As-77 .................... & - & $1 \mathrm{E}-06$ & - & - & $4 \mathrm{E}+04$ & - & $/ \mathrm{St} /$ \\
\hline As-78 …..................... & - & $3 E-06$ & - & - & $1 \mathrm{E}+05$ & - & /ET/ \\
\hline Se-70 …….............. & $2 E-06$ & $2 E-06$ & - & $1 E+05$ & $9 \mathrm{E}+04$ & - & $\mathrm{ET} / \mathrm{ET} /$ \\
\hline Se-73m .................... & $1 E-05$ & $1 \mathrm{E}-05$ & - & $5 E+05$ & $4 \mathrm{E}+05$ & - & $\mathrm{ET} / \mathrm{ET} /$ \\
\hline Se-73 ……............... & $1 \mathrm{E}-06$ & $1 \mathrm{E}-06$ & - & $6 \mathrm{E}+04$ & $5 E+04$ & - & $\mathrm{ET} / \mathrm{ET} /$ \\
\hline Se-75 ……............. & $4 \mathrm{E}-07$ & $3 E-07$ & - & $1 E+04$ & $1 \mathrm{E}+04$ & - & $\mathrm{St} / \mathrm{St} /$ \\
\hline Se-79 ……............. & $3 E-07$ & $1 \mathrm{E}-07$ & - & $1 E+04$ & $6 \mathrm{E}+03$ & - & $\mathrm{K} / \mathrm{St} /$ \\
\hline Se-81m ……............. & $1 \mathrm{E}-05$ & $6 \mathrm{E}-06$ & - & $3 E+05$ & $2 E+05$ & - & $\mathrm{ET} / \mathrm{ET} /$ \\
\hline Se-81 …….............. & $1 E-05$ & $1 \mathrm{E}-05$ & - & $6 E+05$ & $4 E+05$ & - & $\mathrm{ET} / \mathrm{ET} /$ \\
\hline Se-83 ……............... & $6 \mathrm{E}-06$ & $5 E-06$ & - & $2 E+05$ & $1 \mathrm{E}+05$ & - & $\mathrm{ET} / \mathrm{ET} /$ \\
\hline $\mathrm{Br}-74 \mathrm{~m}$ & $3 E-06$ & $2 E-06$ & - & $1 E+05$ & $1 \mathrm{E}+05$ & - & $\mathrm{ET} / \mathrm{ET} /$ \\
\hline $\mathrm{Br}-74$ & $4 E-06$ & $4 \mathrm{E}-06$ & - & $1 E+05$ & $1 \mathrm{E}+05$ & - & $\mathrm{ET} / \mathrm{ET} /$ \\
\hline $\mathrm{Br}-75 \ldots \ldots \ldots \ldots \ldots \ldots$ & $4 \mathrm{E}-06$ & $3 E-06$ & - & $1 \mathrm{E}+05$ & $1 \mathrm{E}+05$ & - & $\mathrm{ET} / \mathrm{ET} /$ \\
\hline $\mathrm{Br}-76$ & $5 E-07$ & $5 E-07$ & - & $2 E+04$ & $2 E+04$ & - & $\mathrm{ET} / \mathrm{ET} /$ \\
\hline $\mathrm{Br}-77$....................... & $2 E-06$ & $2 E-06$ & - & $7 E+04$ & $7 E+04$ & - & $\mathrm{ET} / \mathrm{ET} /$ \\
\hline $\mathrm{Br}-80 \mathrm{~m}$ & $6 \mathrm{E}-06$ & $5 E-06$ & - & $2 E+05$ & $2 E+05$ & - & $\mathrm{ET} / \mathrm{St} /$ \\
\hline $\mathrm{Br}-80 \ldots \ldots \ldots \ldots \ldots \ldots$ & $3 E-05$ & $2 E-05$ & - & $1 \mathrm{E}+06$ & $7 E+05$ & - & $\mathrm{ET} / \mathrm{ET} /$ \\
\hline $\mathrm{Br}-82 \ldots \ldots \ldots \ldots \ldots$ & $3 E-07$ & $3 E-07$ & - & $1 \mathrm{E}+04$ & $1 \mathrm{E}+04$ & - & $\mathrm{ET} / \mathrm{ET} /$ \\
\hline $\mathrm{Br}-83 \quad \ldots \ldots \ldots \ldots \ldots$ & $9 \mathrm{E}-06$ & $6 \mathrm{E}-06$ & - & $3 \mathrm{E}+05$ & $2 \mathrm{E}+05$ & - & $\mathrm{ET} / \mathrm{ET} /$ \\
\hline $\mathrm{Br}-84 \ldots \ldots \ldots \ldots$ & $7 E-06$ & $5 E-06$ & - & $2 E+05$ & $2 E+05$ & - & $\mathrm{ET} / \mathrm{ET} /$ \\
\hline Rb-79 .................... & $8 \mathrm{E}-06$ & - & - & $2 E+05$ & - & - & $\mathrm{ET} / /$ \\
\hline 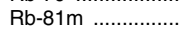 & $1 E-05$ & - & - & $6 \mathrm{E}+05$ & - & - & $\mathrm{ET} / /$ \\
\hline Rb-81 .................... & $2 E-06$ & - & - & $1 \mathrm{E}+05$ & - & - & $\mathrm{ET} / /$ \\
\hline Rb-82m .................... & $8 \mathrm{E}-07$ & - & - & $3 E+04$ & - & - & $\mathrm{ET} /$ / \\
\hline Rb-83 …................. & $5 E-07$ & - & - & $2 E+04$ & - & - & $\mathrm{St} / 1$ \\
\hline Rb-84 …................. & $3 E-07$ & - & - & $1 \mathrm{E}+04$ & - & - & $\mathrm{St} / /$ \\
\hline Rb-86 …................. & $4 \mathrm{E}-07$ & - & - & $1 \mathrm{E}+04$ & - & - & $\mathrm{St} / /$ \\
\hline Rb-87 ….................. & $7 E-07$ & - & - & $2 E+04$ & - & - & St/ / \\
\hline Rb-88 ……............... & $1 E-05$ & - & - & $5 E+05$ & - & - & $\mathrm{ET} / /$ \\
\hline Rb-89 .................... & $1 E-05$ & - & - & $3 E+05$ & - & - & $\mathrm{ET} / /$ \\
\hline Sr-80 …................... & $3 E-06$ & - & $2 E-06$ & $1 \mathrm{E}+05$ & - & $9 \mathrm{E}+04$ & $\mathrm{ET} / / \mathrm{St}$ \\
\hline $\mathrm{Sr}-81 \ldots \ldots \ldots \ldots \ldots$ & $7 E-06$ & - & $5 E-06$ & $2 \mathrm{E}+05$ & - & $2 \mathrm{E}+05$ & ET/ /ET \\
\hline $\mathrm{Sr}-82 \ldots \ldots \ldots \ldots \ldots \ldots$ & $1 E-07$ & - & $7 E-08$ & $6 \mathrm{E}+03$ & - & $2 E+03$ & $\mathrm{St} / \mathrm{St}$ \\
\hline Sr-83 ……............... & $1 \bar{E}-06$ & - & $9 \bar{E}-07$ & $3 E+04$ & - & $3 E+04$ & $\mathrm{ET} / \mathrm{ET}$ \\
\hline $\mathrm{Sr}-85 \mathrm{~m}$ & $4 E-05$ & - & $3 E-05$ & $1 \mathrm{E}+06$ & - & $1 \mathrm{E}+06$ & ET/ /ET \\
\hline Sr-85 ….................... & $1 E-06$ & - & $8 E-07$ & $3 E+04$ & - & $3 E+04$ & $\mathrm{St} / \mathrm{St}$ \\
\hline Sr-87m & $1 \bar{E}-05$ & - & $9 E-06$ & $4 \mathrm{E}+05$ & - & $3 E+05$ & $\mathrm{ET} / \mathrm{ET}$ \\
\hline Sr-89 …1. & $4 \mathrm{E}-07$ & - & $1 \mathrm{E}-07$ & $1 E+04$ & - & $3 E+03$ & $\mathrm{St} / \mathrm{St}$ \\
\hline Sr-90 ……............. & $1 E-08$ & - & $7 E-09$ & $4 \mathrm{E}+02$ & - & $2 E+02$ & $\mathrm{BS} / \mathrm{St}$ \\
\hline Sr-91 …… & $1 \bar{E}-06$ & - & $9 \mathrm{E}-07$ & $5 \mathrm{E}+04$ & - & $3 E+04$ & $\mathrm{ET} / \mathrm{St}$ \\
\hline Sr-92 … & $2 E-06$ & - & $1 E-06$ & $8 \mathrm{E}+04$ & - & $6 \mathrm{E}+04$ & $\mathrm{ET} / \mathrm{St}$ \\
\hline Y-86m …….............. & - & $7 E-06$ & $6 \mathrm{E}-06$ & - & $2 \mathrm{E}+05$ & $2 \mathrm{E}+05$ & $/ \mathrm{ET} / \mathrm{ET}$ \\
\hline Y-86 ………............. & - & $4 \mathrm{E}-07$ & $4 E-07$ & - & $1 \mathrm{E}+04$ & $1 \mathrm{E}+04$ & $/ E T / E T$ \\
\hline Y-87 ……............... & - & $9 \bar{E}-07$ & $8 \bar{E}-07$ & - & $3 E+04$ & $3 E+04$ & /ET/ET \\
\hline 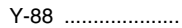 & - & $1 \mathrm{E}-07$ & $1 \mathrm{E}-07$ & - & $6 \mathrm{E}+03$ & $6 \mathrm{E}+03$ & $/ \mathrm{St} / \mathrm{St}$ \\
\hline Y-90m …….............. & - & $4 \mathrm{E}-06$ & $4 E-06$ & - & $1 \mathrm{E}+05$ & $1 \mathrm{E}+05$ & $/ \mathrm{St} / \mathrm{St}$ \\
\hline 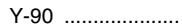 & - & $3 E-07$ & $3 E-07$ & - & $1 E+04$ & $1 \mathrm{E}+04$ & $/ \mathrm{St} / \mathrm{St}$ \\
\hline Y-91m & - & $2 E-05$ & $2 E-05$ & _- & $7 E+05$ & $7 E+05$ & /ET/ET \\
\hline Y-91 ……............. & - & $1 \mathrm{E}-07$ & $9 \bar{E}-08$ & - & $4 E+03$ & $3 E+03$ & $/ \mathrm{St} / \mathrm{St}$ \\
\hline Y-92 ……........... & - & $2 E-06$ & $2 E-06$ & - & $7 E+04$ & $7 E+04$ & $/ \mathrm{St} / \mathrm{St}$ \\
\hline Y-93 ……….......... & - & $9 \mathrm{E}-07$ & $9 \mathrm{E}-07$ & - & $3 E+04$ & $3 E+04$ & $/ \mathrm{St} / \mathrm{St}$ \\
\hline 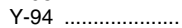 & - & $8 \bar{E}-06$ & $8 \bar{E}-06$ & - & $3 E+05$ & $3 E+05$ & /ET/ET \\
\hline Y-95 …… & - & $1 \mathrm{E}-05$ & $1 \mathrm{E}-05$ & - & $4 E+05$ & $4 \mathrm{E}+05$ & /ET/ET \\
\hline Zr-86 & $5 E-07$ & $5 \bar{E}-07$ & $5 \bar{E}-07$ & $2 \mathrm{E}+04$ & $2 E+04$ & $2 \mathrm{E}+04$ & $\mathrm{ET} / \mathrm{ET} / \mathrm{ET}$ \\
\hline $\mathrm{Zr}-88$ & $1 \mathrm{E}-07$ & $3 E-07$ & $3 E-07$ & $5 E+03$ & $1 E+04$ & $1 E+04$ & $\mathrm{St} / \mathrm{St} / \mathrm{St}$ \\
\hline Zr-89 ……............... & $6 \mathrm{E}-07$ & $6 \mathrm{E}-07$ & $6 E-07$ & $2 E+04$ & $2 E+04$ & $2 E+04$ & ET/ET/ET \\
\hline Zr-93 ….................. & $3 E-09$ & $1 \mathrm{E}-08$ & $1 \mathrm{E}-07$ & $1 \mathrm{E}+02$ & $6 \mathrm{E}+02$ & $5 E+03$ & $\mathrm{BS} / \mathrm{BS} / \mathrm{BS}$ \\
\hline Zr-95 …................. & $9 E-08$ & $1 \mathrm{E}-07$ & $1 \mathrm{E}-07$ & $3 E+03$ & $5 E+03$ & $4 \mathrm{E}+03$ & $\mathrm{BS} / \mathrm{St} / \mathrm{St}$ \\
\hline 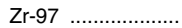 & $7 E-07$ & $4 \mathrm{E}-07$ & $4 \mathrm{E}-07$ & $2 E+04$ & $1 E+04$ & $1 \mathrm{E}+04$ & $\mathrm{ET} / \mathrm{St} / \mathrm{St}$ \\
\hline Nb-88 ….................. & - & $5 E-06$ & $5 E-06$ & - & $1 \mathrm{E}+05$ & $1 \mathrm{E}+05$ & /ET/ET \\
\hline Nb-89 (66 min) & - & $3 E-06$ & $3 E-06$ & - & $1 \mathrm{E}+05$ & $1 E+05$ & /ET/ET \\
\hline $\mathrm{Nb}-89$ (122 $\mathrm{min})$ & - & $2 E-06$ & $2 E-06$ & - & $1 \mathrm{E}+05$ & $1 \mathrm{E}+05$ & /ET/ET \\
\hline $\mathrm{Nb}-90$ & - & $3 E-07$ & $3 E-07$ & - & $1 \mathrm{E}+04$ & $1 \mathrm{E}+04$ & $/ \mathrm{ET} / \mathrm{ET}$ \\
\hline $\mathrm{Nb}-93 \mathrm{~m}$ & - & $1 \mathrm{E}-06$ & $6 \mathrm{E}-07$ & - & $7 E+04$ & $2 E+04$ & $/ \mathrm{St} / \mathrm{St}$ \\
\hline 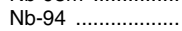 & - & $7 E-08$ & $2 E-08$ & - & $2 E+03$ & $8 \mathrm{E}+02$ & $/ \mathrm{St} / \mathrm{St}$ \\
\hline $\mathrm{Nb}-95 \mathrm{~m}$ & - & $7 E-07$ & $6 \mathrm{E}-07$ & - & $2 E+04$ & $2 E+04$ & $/ \mathrm{St} / \mathrm{St}$ \\
\hline Nb-95 …................. & - & $4 \mathrm{E}-07$ & $4 E-07$ & - & $1 \mathrm{E}+04$ & $1 \mathrm{E}+04$ & $/ \mathrm{St} / \mathrm{St}$ \\
\hline Nb-96 ….................. & - & $4 \mathrm{E}-07$ & $4 \mathrm{E}-07$ & - & $1 \mathrm{E}+04$ & $1 \mathrm{E}+04$ & /ET/ET \\
\hline
\end{tabular}


Department of Energy

Pt. 835, App. A

\begin{tabular}{|c|c|c|c|c|c|c|c|}
\hline \multirow{3}{*}{ Radionuclide } & \multicolumn{3}{|c|}{ Absorption type ${ }^{3}$} & \multicolumn{3}{|c|}{ Absorption type ${ }^{3}$} & \multirow{3}{*}{$\begin{array}{c}\begin{array}{c}\text { Stochastic or } \\
\text { organ or tis- } \\
\text { sue }^{1}\end{array} \\
(\mathrm{~F} / \mathrm{M} / \mathrm{S})\end{array}$} \\
\hline & \multicolumn{3}{|c|}{$\mu \mathrm{Ci} / \mathrm{mL}$} & \multicolumn{3}{|c|}{$\mathrm{Bq} / \mathrm{m}^{3}$} & \\
\hline & $\mathrm{F}$ & M & $S$ & $\mathrm{~F}$ & M & $S$ & \\
\hline $\mathrm{Nb}-97$ & - & $5 E-06$ & $5 E-06$ & - & $1 \mathrm{E}+05$ & $1 \mathrm{E}+05$ & /ET/ET \\
\hline Nb-98 …................ & - & $3 E-06$ & $3 E-06$ & - & $1 \mathrm{E}+05$ & $1 \mathrm{E}+05$ & /ET/ET \\
\hline Mo-90 ……............... & $8 E-07$ & - & $7 E-07$ & $3 \mathrm{E}+04$ & - & $2 \mathrm{E}+04$ & $\mathrm{ET} / \quad / \mathrm{ET}$ \\
\hline Mo-93m .................. & $1 E-06$ & - & $1 E-06$ & $3 E+04$ & - & $3 \mathrm{E}+04$ & $\mathrm{ET} / / \mathrm{ET}$ \\
\hline Mo-93 …….............. & $2 \mathrm{E}-07$ & - & $4 E-07$ & $7 \mathrm{E}+03$ & - & $1 \mathrm{E}+04$ & $\mathrm{BS} / \mathrm{St}$ \\
\hline Mo-99 ……............... & $1 E-06$ & - & $5 E-07$ & $5 \mathrm{E}+04$ & - & $1 \mathrm{E}+04$ & E/ /St \\
\hline Mo-101 .................... & $8 E-06$ & - & $6 E-06$ & $3 E+05$ & - & $2 E+05$ & $\mathrm{ET} / \quad / \mathrm{ET}$ \\
\hline Tc-93m .................... & $8 E-06$ & $7 E-06$ & - & $3 E+05$ & $2 \mathrm{E}+05$ & - & $\mathrm{ET} / \mathrm{ET} /$ \\
\hline Тc-93 …… & $3 E-06$ & $3 E-06$ & - & $1 \mathrm{E}+05$ & $1 \mathrm{E}+05$ & - & $\mathrm{ET} / \mathrm{ET} /$ \\
\hline Tc-94m .................. & $5 E-06$ & $4 E-06$ & - & $1 \mathrm{E}+05$ & $1 \mathrm{E}+05$ & - & $\mathrm{ET} / \mathrm{ET} /$ \\
\hline Tc-94 …….............. & $1 E-06$ & $1 E-06$ & - & $4 \mathrm{E}+04$ & $3 \mathrm{E}+04$ & - & $\mathrm{ET} / \mathrm{ET} /$ \\
\hline Tc-95m .................. & $8 E-07$ & $6 \mathrm{E}-07$ & - & $3 \mathrm{E}+04$ & $2 \mathrm{E}+04$ & - & $\mathrm{ET} / \mathrm{St} /$ \\
\hline Tc-95 ……........... & $1 E-06$ & $1 E-06$ & - & $5 E+04$ & $5 \mathrm{E}+04$ & - & $\mathrm{ET} / \mathrm{ET} /$ \\
\hline Tc-96m ................... & $2 E-05$ & $2 E-05$ & - & $1 \mathrm{E}+06$ & $1 \mathrm{E}+06$ & - & $\mathrm{ET} / \mathrm{ET} /$ \\
\hline Tc-96 ........ & $3 E-07$ & $3 E-07$ & - & $1 \mathrm{E}+04$ & $1 \mathrm{E}+04$ & - & $\mathrm{ET} / \mathrm{ET} /$ \\
\hline Tc-97m ……........... & $1 E-06$ & $2 E-07$ & - & $5 E+04$ & $7 \mathrm{E}+03$ & - & $\mathrm{St} / \mathrm{St} /$ \\
\hline Tc-97 …................ & $4 E-06$ & $3 E-06$ & - & $1 \mathrm{E}+05$ & $1 \mathrm{E}+05$ & - & $\mathrm{ET} / \mathrm{St} /$ \\
\hline Tc-98 ………....... & $3 E-07$ & $9 \mathrm{E}-08$ & - & $1 \mathrm{E}+04$ & $3 \mathrm{E}+03$ & - & $\mathrm{St} / \mathrm{St} /$ \\
\hline Tc-99m ……............ & $1 E-05$ & $1 E-05$ & - & $5 \mathrm{E}+05$ & $4 \mathrm{E}+05$ & - & $\mathrm{ET} / \mathrm{ET} /$ \\
\hline Tc-99 ……............. & $1 E-06$ & $1 \bar{E}-07$ & - & $5 \mathrm{E}+04$ & $6 \mathrm{E}+03$ & - & $\mathrm{St} / \mathrm{St} /$ \\
\hline Tc-101 .................. & $1 E-05$ & $1 E-05$ & - & $6 \mathrm{E}+05$ & $4 \mathrm{E}+05$ & - & $\mathrm{ET} / \mathrm{ET} /$ \\
\hline Tc-104 …....... & $9 E-06$ & $7 E-06$ & - & $3 \mathrm{E}+05$ & $2 \mathrm{E}+05$ & - & $\mathrm{ET} / \mathrm{ET} /$ \\
\hline Ru-94 …….............. & $5 E-06$ & $5 E-06$ & $5 E-06$ & $2 \mathrm{E}+05$ & $1 \mathrm{E}+05$ & $1 \mathrm{E}+05$ & ET/ET/ET \\
\hline Ru-97 ...................... & $2 E-06$ & $2 E-06$ & $2 E-06$ & $8 \mathrm{E}+04$ & $8 \mathrm{E}+04$ & $8 \mathrm{E}+04$ & ET/ET/ET \\
\hline Ru-103 & $8 E-07$ & $2 E-07$ & $2 E-07$ & $3 \mathrm{E}+04$ & $1 \mathrm{E}+04$ & $9 \mathrm{E}+03$ & $\mathrm{St} / \mathrm{St} / \mathrm{St}$ \\
\hline Ru-105 .................... & $2 E-06$ & $2 E-06$ & $2 E-06$ & $9 \mathrm{E}+04$ & $8 \mathrm{E}+04$ & $8 \mathrm{E}+04$ & ET/ET/ET \\
\hline Ru-106 .................... & $5 E-08$ & $3 E-08$ & $1 \mathrm{E}-08$ & $2 \mathrm{E}+03$ & $1 \mathrm{E}+03$ & $5 \mathrm{E}+02$ & $\mathrm{St} / \mathrm{St} / \mathrm{St}$ \\
\hline Rh-99m .................. & $3 E-06$ & $3 E-06$ & $3 E-06$ & $1 \mathrm{E}+05$ & $1 \mathrm{E}+05$ & $1 \mathrm{E}+05$ & ET/ET/ET \\
\hline Rh-99 ……............... & $8 E-07$ & $6 E-07$ & $6 \mathrm{E}-07$ & $3 \mathrm{E}+04$ & $2 \mathrm{E}+04$ & $2 \mathrm{E}+04$ & $\mathrm{ET} / \mathrm{St} / \mathrm{St}$ \\
\hline Rh-100 .................... & $5 E-07$ & $5 E-07$ & $5 E-07$ & $1 \mathrm{E}+04$ & $1 \mathrm{E}+04$ & $1 \mathrm{E}+04$ & ET/ET/ET \\
\hline Rh-101m ................ & $1 E-06$ & $1 E-06$ & $1 E-06$ & $6 \mathrm{E}+04$ & $6 \mathrm{E}+04$ & $6 \mathrm{E}+04$ & ET/ET/ET \\
\hline Rh-101 ……............ & $3 E-07$ & $3 E-07$ & $1 \mathrm{E}-07$ & $1 \mathrm{E}+04$ & $1 \mathrm{E}+04$ & $6 \mathrm{E}+03$ & $\mathrm{St} / \mathrm{St} / \mathrm{St}$ \\
\hline Rh-102m ................ & $2 E-07$ & $2 E-07$ & $1 \mathrm{E}-07$ & $1 \mathrm{E}+04$ & $7 \mathrm{E}+03$ & $4 \mathrm{E}+03$ & $\mathrm{St} / \mathrm{St} / \mathrm{St}$ \\
\hline Rh-102 ..................... & $6 \mathrm{E}-08$ & $1 E-07$ & $6 E-08$ & $2 \mathrm{E}+03$ & $4 \mathrm{E}+03$ & $2 \mathrm{E}+03$ & $\mathrm{St} / \mathrm{St} / \mathrm{St}$ \\
\hline Rh-103m ................. & $4 \mathrm{E}-04$ & $2 E-04$ & $2 E-04$ & $1 \mathrm{E}+07$ & $8 \mathrm{E}+06$ & $8 \mathrm{E}+06$ & $\mathrm{St} / \mathrm{St} / \mathrm{St}$ \\
\hline Rh-105 ..................... & $3 E-06$ & $1 E-06$ & $1 E-06$ & $1 \mathrm{E}+05$ & $5 \mathrm{E}+04$ & $4 \mathrm{E}+04$ & $\mathrm{ET} / \mathrm{St} / \mathrm{St}$ \\
\hline Rh-106m ................ & $1 E-06$ & $1 E-06$ & $1 E-06$ & $6 \mathrm{E}+04$ & $5 \mathrm{E}+04$ & $5 E+04$ & ET/ET/ET \\
\hline Rh-107 …............... & $1 E-05$ & $9 \mathrm{E}-06$ & $9 E-06$ & $5 \mathrm{E}+05$ & $3 \mathrm{E}+05$ & $3 \mathrm{E}+05$ & ET/ET/ET \\
\hline Pd-100 ..................... & $5 E-07$ & $5 E-07$ & $5 E-07$ & $2 \mathrm{E}+04$ & $2 \mathrm{E}+04$ & $2 \mathrm{E}+04$ & ET/ET/ET \\
\hline Pd-101 ……............ & $3 E-06$ & $3 E-06$ & $3 E-06$ & $1 \mathrm{E}+05$ & $1 \mathrm{E}+05$ & $1 \mathrm{E}+05$ & $\mathrm{ET} / \mathrm{ET} / \mathrm{ET}$ \\
\hline Pd-103 …….............. & $4 \mathrm{E}-06$ & $1 \mathrm{E}-06$ & $1 \mathrm{E}-06$ & $1 \mathrm{E}+05$ & $6 \mathrm{E}+04$ & $7 \mathrm{E}+04$ & $\mathrm{E} / \mathrm{St} / \mathrm{St}$ \\
\hline Pd-107 ..................... & $1 E-05$ & $1 E-05$ & $1 E-06$ & $5 \mathrm{E}+05$ & $4 \mathrm{E}+05$ & $7 \mathrm{E}+04$ & $\mathrm{~K} / \mathrm{St} / \mathrm{St}$ \\
\hline Pd-109 ..................... & $2 E-06$ & $1 E-06$ & $1 \mathrm{E}-06$ & $9 \mathrm{E}+04$ & $4 \mathrm{E}+04$ & $4 \mathrm{E}+04$ & $\mathrm{St} / \mathrm{St} / \mathrm{St}$ \\
\hline Ag-102 ................... & $9 E-06$ & $7 E-06$ & $7 E-06$ & $3 \mathrm{E}+05$ & $2 \mathrm{E}+05$ & $2 \mathrm{E}+05$ & ET/ET/ET \\
\hline Ag-103 & $8 E-06$ & $7 E-06$ & $7 E-06$ & $3 \mathrm{E}+05$ & $2 \mathrm{E}+05$ & $2 \mathrm{E}+05$ & ET/ET/ET \\
\hline Ag-104m ................. & $8 E-06$ & $6 E-06$ & $6 E-06$ & $2 \mathrm{E}+05$ & $2 \mathrm{E}+05$ & $2 \mathrm{E}+05$ & ET/ET/ET \\
\hline Ag-104 …............... & $3 E-06$ & $3 E-06$ & $3 E-06$ & $1 \mathrm{E}+05$ & $1 \mathrm{E}+05$ & $1 \mathrm{E}+05$ & ET/ET/ET \\
\hline Ag-105 . & $7 \mathrm{E}-07$ & $8 E-07$ & $7 E-07$ & $2 \mathrm{E}+04$ & $2 \mathrm{E}+04$ & $2 \mathrm{E}+04$ & $\mathrm{St} / \mathrm{St} / \mathrm{St}$ \\
\hline Ag-106m …............. & $2 \mathrm{E}-07$ & $2 E-07$ & $2 E-07$ & $9 \mathrm{E}+03$ & $9 \mathrm{E}+03$ & $9 \mathrm{E}+03$ & ET/ET/ET \\
\hline Ag-106 .................. & $1 E-05$ & $1 E-05$ & $1 E-05$ & $5 \mathrm{E}+05$ & $4 \mathrm{E}+05$ & $4 \mathrm{E}+05$ & ET/ET/ET \\
\hline $\mathrm{Ag}-108 \mathrm{~m} \ldots \ldots$ & $7 E-08$ & $1 E-07$ & $2 E-08$ & $2 \mathrm{E}+03$ & $4 \mathrm{E}+03$ & $1 \mathrm{E}+03$ & $\mathrm{St} / \mathrm{St} / \mathrm{St}$ \\
\hline Ag-110m …............. & $8 E-08$ & $9 E-08$ & $7 E-08$ & $3 \mathrm{E}+03$ & $3 \mathrm{E}+03$ & $2 \mathrm{E}+03$ & $\mathrm{St} / \mathrm{St} / \mathrm{St}$ \\
\hline Ag-111 .................. & $9 E-07$ & $3 E-07$ & $3 E-07$ & $3 E+04$ & $1 \mathrm{E}+04$ & $1 \mathrm{E}+04$ & $\mathrm{St} / \mathrm{St} / \mathrm{St}$ \\
\hline Ag-112 …................. & $4 E-06$ & $2 E-06$ & $2 E-06$ & $1 \mathrm{E}+05$ & $8 \mathrm{E}+04$ & $8 \mathrm{E}+04$ & $\mathrm{E} / \mathrm{St} / \mathrm{St}$ \\
\hline Ag-115 ................... & $1 \mathrm{E}-05$ & $8 E-06$ & $8 E-06$ & $4 \mathrm{E}+05$ & $3 \mathrm{E}+05$ & $3 \mathrm{E}+05$ & ET/ET/ET \\
\hline Cd-104 ……............. & $4 \mathrm{E}-06$ & $4 E-06$ & $4 E-06$ & $1 \mathrm{E}+05$ & $1 \mathrm{E}+05$ & $1 \mathrm{E}+05$ & $\mathrm{ET} / \mathrm{ET} / \mathrm{ET}$ \\
\hline Cd-107 .................. & $5 E-06$ & $5 E-06$ & $4 E-06$ & $2 \mathrm{E}+05$ & $1 \mathrm{E}+05$ & $1 \mathrm{E}+05$ & ET/ET/ET \\
\hline Cd-109. & $2 E-08$ & $9 \mathrm{E}-08$ & $1 \mathrm{E}-07$ & $9 \mathrm{E}+02$ & $3 \mathrm{E}+03$ & $4 \mathrm{E}+03$ & $\mathrm{~K} / \mathrm{K} / \mathrm{St}$ \\
\hline Cd-113m ................. & $1 E-09$ & $6 \bar{E}-09$ & $1 \bar{E}-08$ & $6 \mathrm{E}+01$ & $2 \mathrm{E}+02$ & $6 \mathrm{E}+02$ & $\mathrm{~K} / \mathrm{K} / \mathrm{K}$ \\
\hline Cd-113 .................. & $1 E-09$ & $5 E-09$ & $1 E-08$ & $5 \mathrm{E}+01$ & $2 \mathrm{E}+02$ & $5 \mathrm{E}+02$ & $\mathrm{~K} / \mathrm{K} / \mathrm{K}$ \\
\hline Cd-115m ….............. & $3 E-08$ & $1 E-07$ & $1 \mathrm{E}-07$ & $1 \mathrm{E}+03$ & $3 \mathrm{E}+03$ & $3 \mathrm{E}+03$ & $\mathrm{~K} / \mathrm{St} / \mathrm{St}$ \\
\hline Cd-115 …............ & $9 \mathrm{E}-07$ & $4 E-07$ & $4 E-07$ & $3 \mathrm{E}+04$ & $1 \mathrm{E}+04$ & $1 \mathrm{E}+04$ & $\mathrm{~K} / \mathrm{St} / \mathrm{St}$ \\
\hline Cd-117m. & $1 E-06$ & $1 E-06$ & $1 \mathrm{E}-06$ & $4 \mathrm{E}+04$ & $4 \mathrm{E}+04$ & $4 \mathrm{E}+04$ & ET/ET/ET \\
\hline Cd-117 ..................... & $2 E-06$ & $2 E-06$ & $2 E-06$ & $8 \mathrm{E}+04$ & $7 \mathrm{E}+04$ & $7 \mathrm{E}+04$ & ET/ET/ET \\
\hline ln-109 …............... & $4 E-06$ & $4 E-06$ & - & $1 \mathrm{E}+05$ & $1 \mathrm{E}+05$ & - & $\mathrm{ET} / \mathrm{ET} /$ \\
\hline In-110 (69 min) & $5 E-06$ & $4 \mathrm{E}-06$ & - & $1 \mathrm{E}+05$ & $1 \mathrm{E}+05$ & - & $\mathrm{ET} / \mathrm{ET} /$ \\
\hline $\ln -110(5 \mathrm{~h}) \ldots \ldots \ldots$ & $9 \mathrm{E}-07$ & $9 \mathrm{E}-07$ & - & $3 \mathrm{E}+04$ & $3 \mathrm{E}+04$ & - & $\mathrm{ET} / \mathrm{ET} /$ \\
\hline ln-111 …................... & $1 E-06$ & $1 E-06$ & - & $5 E+04$ & $5 \mathrm{E}+04$ & - & $\mathrm{ET} / \mathrm{ET} /$ \\
\hline $\ln -112 \ldots \ldots \ldots \ldots \ldots \ldots$ & $2 E-05$ & $1 E-05$ & - & $9 \mathrm{E}+05$ & $6 \mathrm{E}+05$ & - & $\mathrm{ET} / \mathrm{ET} /$ \\
\hline In-113m ............... & $1 E-05$ & $1 E-05$ & - & $4 \mathrm{E}+05$ & $3 \mathrm{E}+05$ & - & $\mathrm{ET} / \mathrm{ET} /$ \\
\hline $\ln -114 \mathrm{~m} \ldots \ldots$. & $5 E-08$ & $9 \mathrm{E}-08$ & - & $1 \mathrm{E}+03$ & $3 \mathrm{E}+03$ & - & $\mathrm{St} / \mathrm{St} /$ \\
\hline
\end{tabular}


Pt. 835, App. A

10 CFR Ch. III (1-1-08 Edition)

\begin{tabular}{|c|c|c|c|c|c|c|c|}
\hline \multirow{3}{*}{ Radionuclide } & \multicolumn{3}{|c|}{ Absorption type ${ }^{3}$} & \multicolumn{3}{|c|}{ Absorption type ${ }^{3}$} & \multirow{3}{*}{$\begin{array}{c}\begin{array}{c}\text { Stochastic or } \\
\text { organ or tis- } \\
\text { sue }^{1}\end{array} \\
(\mathrm{~F} / \mathrm{M} / \mathrm{S})\end{array}$} \\
\hline & \multicolumn{3}{|c|}{$\mu \mathrm{Ci} / \mathrm{mL}$} & \multicolumn{3}{|c|}{$\mathrm{Bq} / \mathrm{m}^{3}$} & \\
\hline & $\mathrm{F}$ & M & s & $\mathrm{F}$ & M & S & \\
\hline In-115m & $6 \mathrm{E}-06$ & $5 E-06$ & - & $2 E+05$ & $2 \mathrm{E}+05$ & - & $\mathrm{ET} / \mathrm{ET} /$ \\
\hline In-115 .................... & $1 E-09$ & $5 E-09$ & - & $4 \mathrm{E}+01$ & $1 \mathrm{E}+02$ & - & $\mathrm{St} / \mathrm{St} /$ \\
\hline In-116m .................. & $4 \mathrm{E}-06$ & $3 E-06$ & - & $1 \mathrm{E}+05$ & $1 \mathrm{E}+05$ & - & $\mathrm{ET} / \mathrm{ET} /$ \\
\hline In-117m .................. & $5 E-06$ & $4 E-06$ & - & $2 \mathrm{E}+05$ & $1 \mathrm{E}+05$ & - & $\mathrm{ET} / \mathrm{ET} /$ \\
\hline ln-117 ........................ & $7 \mathrm{E}-06$ & $5 E-06$ & - & $2 \mathrm{E}+05$ & $2 E+05$ & - & $\mathrm{ET} / \mathrm{ET} /$ \\
\hline In-119m .................. & $1 E-05$ & $1 \mathrm{E}-05$ & - & $6 \mathrm{E}+05$ & $4 \mathrm{E}+05$ & - & $\mathrm{ET} / \mathrm{ET} /$ \\
\hline $\mathrm{Sn}-110 \ldots \ldots \ldots \ldots \ldots$ & $1 \mathrm{E}-06$ & $1 \mathrm{E}-06$ & - & $6 \mathrm{E}+04$ & $6 \mathrm{E}+04$ & - & $\mathrm{ET} / \mathrm{ET} /$ \\
\hline Sn-111 .................... & $1 E-05$ & $1 \mathrm{E}-05$ & - & $6 \mathrm{E}+05$ & $5 E+05$ & - & $\mathrm{ET} / \mathrm{ET} /$ \\
\hline Sn-113 & $7 E-07$ & $2 E-07$ & - & $2 E+04$ & $1 \mathrm{E}+04$ & - & $\mathrm{St} / \mathrm{St} /$ \\
\hline $\mathrm{Sn}-117 \mathrm{~m}$ & $8 \mathrm{E}-07$ & $2 E-07$ & - & $3 E+04$ & $9 \mathrm{E}+03$ & - & $\mathrm{BS} / \mathrm{St} /$ \\
\hline Sn-119m ................. & $1 \mathrm{E}-06$ & $3 E-07$ & - & $5 E+04$ & $1 \mathrm{E}+04$ & - & $\mathrm{St} / \mathrm{St} /$ \\
\hline Sn-121m …............ & $5 E-07$ & $1 \mathrm{E}-07$ & - & $2 \mathrm{E}+04$ & $6 \mathrm{E}+03$ & - & $\mathrm{St} / \mathrm{St} /$ \\
\hline Sn-121 .................... & $4 \mathrm{E}-06$ & $2 E-06$ & - & $1 \mathrm{E}+05$ & $7 E+04$ & - & $\mathrm{ET} / \mathrm{St} /$ \\
\hline Sn-123m ................. & $1 E-05$ & $7 E-06$ & - & $4 \mathrm{E}+05$ & $2 E+05$ & - & $\mathrm{ET} / \mathrm{ET} /$ \\
\hline Sn-123 & $3 E-07$ & $1 \mathrm{E}-07$ & - & $1 \mathrm{E}+04$ & $3 \mathrm{E}+03$ & - & $\mathrm{St} / \mathrm{St} /$ \\
\hline Sn-125 & $4 \mathrm{E}-07$ & $2 E-07$ & - & $1 \mathrm{E}+04$ & $7 E+03$ & - & $\mathrm{St} / \mathrm{St} /$ \\
\hline Sn-126 & $4 \mathrm{E}-08$ & $3 E-08$ & - & $1 \mathrm{E}+03$ & $1 \mathrm{E}+03$ & - & $\mathrm{St} / \mathrm{St} /$ \\
\hline Sn-127 & $2 E-06$ & $2 E-06$ & - & $9 \mathrm{E}+04$ & $7 E+04$ & - & $\mathrm{ET} / \mathrm{ET} /$ \\
\hline Sn-128 & $2 E-06$ & $2 E-06$ & - & $1 \mathrm{E}+05$ & $8 \mathrm{E}+04$ & - & $\mathrm{ET} / \mathrm{ET} /$ \\
\hline Sb-115 …................ & $1 \mathrm{E}-05$ & $1 \mathrm{E}-05$ & - & $5 E+05$ & $4 \mathrm{E}+05$ & - & $\mathrm{ET} / \mathrm{ET} /$ \\
\hline Sb-116m ................ & $3 E-06$ & $2 E-06$ & - & $1 \mathrm{E}+05$ & $1 \mathrm{E}+05$ & - & $\mathrm{ET} / \mathrm{ET} /$ \\
\hline Sb-116 …................. & $1 E-05$ & $1 E-05$ & - & $4 \mathrm{E}+05$ & $3 \mathrm{E}+05$ & - & $\mathrm{ET} / \mathrm{ET} /$ \\
\hline Sb-117 …................ & $1 E-05$ & $1 E-05$ & - & $4 \mathrm{E}+05$ & $3 \mathrm{E}+05$ & - & $\mathrm{ET} / \mathrm{ET} /$ \\
\hline Sb-118m ……........... & $1 \mathrm{E}-06$ & $1 \mathrm{E}-06$ & - & $4 \mathrm{E}+04$ & $4 \mathrm{E}+04$ & - & $\mathrm{ET} / \mathrm{ET} /$ \\
\hline Sb-119 …................. & $6 \mathrm{E}-06$ & $6 \mathrm{E}-06$ & - & $2 \mathrm{E}+05$ & $2 \mathrm{E}+05$ & - & $\mathrm{ET} / \mathrm{ET} /$ \\
\hline Sb-120 (16 $\mathrm{min}) .$. & $2 E-05$ & $2 E-05$ & - & $1 \mathrm{E}+06$ & $7 \mathrm{E}+05$ & - & $\mathrm{ET} / \mathrm{ET} /$ \\
\hline Sb-120 (6 d) ............... & $3 \mathrm{E}-07$ & $3 E-07$ & - & $1 \mathrm{E}+04$ & $1 \mathrm{E}+04$ & - & $\mathrm{ET} / \mathrm{ET} /$ \\
\hline Sb-122 …................. & $8 \mathrm{E}-07$ & $4 \mathrm{E}-07$ & - & $3 \mathrm{E}+04$ & $1 \mathrm{E}+04$ & - & $\mathrm{St} / \mathrm{St} /$ \\
\hline Sb-124m …............. & $4 \mathrm{E}-05$ & $3 E-05$ & - & $1 \mathrm{E}+06$ & $1 \mathrm{E}+06$ & - & $\mathrm{ET} / \mathrm{ET} /$ \\
\hline Sb-124 …................ & $2 E-07$ & $1 \mathrm{E}-07$ & - & $1 \mathrm{E}+04$ & $4 E+03$ & - & $\mathrm{St} / \mathrm{St} /$ \\
\hline Sb-125 …................ & $2 E-07$ & $1 \mathrm{E}-07$ & - & $7 \mathrm{E}+03$ & $6 \mathrm{E}+03$ & - & $\mathrm{BS} / \mathrm{St} /$ \\
\hline Sb-126m ……........... & $1 \mathrm{E}-05$ & $7 E-06$ & - & $3 E+05$ & $2 \mathrm{E}+05$ & - & $\mathrm{ET} / \mathrm{ET} /$ \\
\hline Sb-126 .................... & $2 E-07$ & $1 \mathrm{E}-07$ & - & $9 \mathrm{E}+03$ & $6 E+03$ & - & $\mathrm{ET} / \mathrm{St} /$ \\
\hline Sb-127 ............ & $7 E-07$ & $3 E-07$ & - & $2 \mathrm{E}+04$ & $1 \mathrm{E}+04$ & - & $\mathrm{E} / \mathrm{St} /$ \\
\hline Sb-128 (9 h) ........ & $5 E-07$ & $5 E-07$ & - & $2 \mathrm{E}+04$ & $2 \mathrm{E}+04$ & - & ET/ET/ \\
\hline Sb-128 (10 $\mathrm{min}) .$. & $1 E-05$ & $9 E-06$ & - & $4 \mathrm{E}+05$ & $3 E+05$ & - & $\mathrm{ET} / \mathrm{ET} /$ \\
\hline Sb-129 ..................... & $1 \mathrm{E}-06$ & $1 \mathrm{E}-06$ & - & $6 \mathrm{E}+04$ & $5 E+04$ & - & $\mathrm{ET} / \mathrm{ET} /$ \\
\hline Sb-130 & $3 E-06$ & $2 E-06$ & - & $1 \mathrm{E}+05$ & $1 \mathrm{E}+05$ & - & ET/ET/ \\
\hline Sb-131 …................ & $6 \mathrm{E}-06$ & $4 E-06$ & - & $2 E+05$ & $1 \mathrm{E}+05$ & - & $\mathrm{ET} / \mathrm{ET} /$ \\
\hline Te-116 (Vapor) ... & - & $6 E-06$ & - & - & $2 \mathrm{E}+05$ & - & /St / \\
\hline Te-116 & $2 E-06$ & $2 E-06$ & - & $8 \mathrm{E}+04$ & $7 \mathrm{E}+04$ & - & ET/ET/ \\
\hline Te-121m (Vapor) & - & $4 E-08$ & - & - & $1 \mathrm{E}+03$ & - & /BS/ \\
\hline Te-121m ................. & $1 \mathrm{E}-07$ & $1 E-07$ & - & $4 \mathrm{E}+03$ & $5 \mathrm{E}+03$ & - & $\mathrm{BS} / \mathrm{St} /$ \\
\hline Te-121 (Vapor) ... & - & $1 E-06$ & - & - & $4 \mathrm{E}+04$ & - & $/ \mathrm{St} /$ \\
\hline Te-121 & $1 \mathrm{E}-06$ & $1 E-06$ & - & $3 \mathrm{E}+04$ & $3 \mathrm{E}+04$ & - & $\mathrm{ET} / \mathrm{ET} /$ \\
\hline Te-123m (Vapor) & - & $5 E-08$ & - & - & $2 E+03$ & - & /BS/ \\
\hline Te-123m ................. & $1 \mathrm{E}-07$ & $1 \mathrm{E}-07$ & - & $4 \mathrm{E}+03$ & $6 \mathrm{E}+03$ & - & $\mathrm{BS} / \mathrm{St} /$ \\
\hline Te-123 (Vapor) & - & $1 E-08$ & - & - & $4 \mathrm{E}+02$ & - & /BS/ \\
\hline Te-123 & $2 E-08$ & $5 E-08$ & - & $1 \mathrm{E}+03$ & $1 \mathrm{E}+03$ & - & BS/BS/ \\
\hline Te-125m (Vapor) & - & $1 \mathrm{E}-07$ & - & - & $3 E+03$ & - & /BS/ \\
\hline Te-125m .................. & $2 \mathrm{E}-07$ & $1 \mathrm{E}-07$ & - & $9 \mathrm{E}+03$ & $7 E+03$ & - & $\mathrm{BS} / \mathrm{St} /$ \\
\hline Te-127m (Vapor) & - & $6 E-08$ & - & - & $2 E+03$ & - & /BS/ \\
\hline Te-127m ....... & $1 \mathrm{E}-07$ & $9 E-08$ & - & $5 \mathrm{E}+03$ & $3 \mathrm{E}+03$ & - & $\mathrm{BS} / \mathrm{St} /$ \\
\hline Te-127 (Vapor) ... & - & $7 E-06$ & - & - & $2 E+05$ & - & $/ \mathrm{St} /$ \\
\hline Te-127 …............... & $5 \mathrm{E}-06$ & $3 E-06$ & - & $2 \mathrm{E}+05$ & $1 \mathrm{E}+05$ & - & $\mathrm{ET} / \mathrm{St} /$ \\
\hline Te-129m (Vapor) & - & $1 \mathrm{E}-07$ & - & - & $5 E+03$ & - & $/ \mathrm{St} /$ \\
\hline Te-129m .................. & $3 E-07$ & $1 \mathrm{E}-07$ & - & $1 \mathrm{E}+04$ & $3 E+03$ & - & $\mathrm{St} / \mathrm{St} /$ \\
\hline Te-129 (Vapor) ... & - & $1 E-05$ & - & - & $5 \mathrm{E}+05$ & - & $/ \mathrm{St} /$ \\
\hline Te-129 & $1 \mathrm{E}-05$ & $7 E-06$ & - & $4 \mathrm{E}+05$ & $2 E+05$ & - & $\mathrm{ET} / \mathrm{ET} /$ \\
\hline Te-131m (Vapor) & - & $1 E-07$ & - & - & $5 \mathrm{E}+03$ & - & $/ \mathrm{T} /$ \\
\hline $\mathrm{Te}-131 \mathrm{~m}$ & $3 E-07$ & $3 E-07$ & - & $1 \mathrm{E}+04$ & $1 \mathrm{E}+04$ & - & $\mathrm{T} / \mathrm{St} /$ \\
\hline Te-131 (Vapor) ... & - & $6 \mathrm{E}-06$ & - & - & $2 E+05$ & - & $/ \mathrm{T} /$ \\
\hline Te-131 ..................... & $1 E-05$ & $7 E-06$ & - & $4 \mathrm{E}+05$ & $2 E+05$ & - & ET/ET/ \\
\hline Te-132 (Vapor) ... & - & $7 E-08$ & - & - & $2 E+03$ & - & $/ \mathrm{T} /$ \\
\hline Te-132 ...................... & $1 \mathrm{E}-07$ & $1 \mathrm{E}-07$ & - & $6 \mathrm{E}+03$ & $6 \mathrm{E}+03$ & - & $\mathrm{T} / \mathrm{St} /$ \\
\hline Te-133m (Vapor) & - & $1 \mathrm{E}-06$ & - & - & $6 \mathrm{E}+04$ & - & $/ \mathrm{T} /$ \\
\hline Te-133m ................ & $3 E-06$ & $2 E-06$ & - & $1 \mathrm{E}+05$ & $1 \mathrm{E}+05$ & - & T/ET/ \\
\hline Te-133 (Vapor) ... & - & $7 E-06$ & - & - & $2 E+05$ & - & $/ \mathrm{T} /$ \\
\hline Te-133 .................. & $1 E-05$ & $9 E-06$ & - & $4 \mathrm{E}+05$ & $3 E+05$ & - & $\mathrm{ET} / \mathrm{ET} /$ \\
\hline Te-134 (Vapor) ... & - & $6 E-06$ & - & - & $2 E+05$ & - & $/ \mathrm{St} /$ \\
\hline Te-134 & $3 E-06$ & $2 E-06$ & - & $1 \mathrm{E}+05$ & $1 \mathrm{E}+05$ & - & | ET/ET/ \\
\hline
\end{tabular}


Department of Energy

Pt. 835, App. A

\begin{tabular}{|c|c|c|c|c|c|c|c|}
\hline \multirow{3}{*}{ Radionuclide } & \multicolumn{3}{|c|}{ Absorption type ${ }^{3}$} & \multicolumn{3}{|c|}{ Absorption type ${ }^{3}$} & \multirow{2}{*}{$\begin{array}{l}\text { Stochastic or } \\
\text { organ or tis- } \\
\text { sue } 1\end{array}$} \\
\hline & \multicolumn{3}{|c|}{$\mu \mathrm{Ci} / \mathrm{mL}$} & \multicolumn{3}{|c|}{$\mathrm{Bq} / \mathrm{m}^{3}$} & \\
\hline & $\mathrm{F}$ & $M$ & $S$ & $\mathrm{~F}$ & M & $S$ & $(\mathrm{~F} / \mathrm{M} / \mathrm{S})$ \\
\hline I-120m (Methyl) .. & $4 E-06$ & - & - & $1 \mathrm{E}+05$ & - & - & $\mathrm{T} / \mathrm{l}$ \\
\hline I-120m (Vapor) $\ldots$ & - & $3 E-06$ & - & - & $1 \mathrm{E}+05$ & - & /St / \\
\hline $\mathrm{l}-120 \mathrm{~m}$ & $2 E-06$ & - & - & $8 \mathrm{E}+04$ & - & - & $\mathrm{ET} / /$ \\
\hline $\mathrm{l}-120$ (Methyl) ..... & $1 E-06$ & - & - & $6 \mathrm{E}+04$ & - & - & $\mathrm{T} / \mathrm{l}$ \\
\hline I-120 (Vapor) ...... & - & $1 \mathrm{E}-06$ & - & - & $5 \mathrm{E}+04$ & - & $/ \mathrm{T} /$ \\
\hline $\mathrm{I}-120$ & $2 E-06$ & - & - & $1 \mathrm{E}+05$ & - & - & E/ / \\
\hline l-121 (Methyl) ..... & $5 E-06$ & - & - & $2 E+05$ & - & - & $\mathrm{T} / 1$ \\
\hline I-121 (Vapor) ...... & - & $4 \mathrm{E}-06$ & - & - & $1 E+05$ & - & $/ \mathrm{T} /$ \\
\hline $\mathrm{|}-121$ & $8 E-06$ & - & - & $3 E+05$ & - & - & $\mathrm{T} / \mathrm{l}$ \\
\hline l-123 (Methyl) ..... & $1 E-06$ & - & - & $7 E+04$ & - & - & $\mathrm{T} / \mathrm{l}$ \\
\hline I-123 (Vapor) ........ & - & $1 E-06$ & - & - & $5 E+04$ & - & $/ \mathrm{T} /$ \\
\hline $\mathrm{l}-123$ & $2 E-06$ & - & - & $1 E+05$ & - & - & $\mathrm{T} / /$ \\
\hline l-124 (Methyl) ..... & $3 E-08$ & - & - & $1 \mathrm{E}+03$ & - & - & $\mathrm{T} / \mathrm{l}$ \\
\hline I-124 (Vapor) ....... & - & $2 E-08$ & - & - & $9 \mathrm{E}+02$ & - & $/ \mathrm{T} /$ \\
\hline $\mathrm{l}-124$ & $4 \mathrm{E}-08$ & - & - & $1 \mathrm{E}+03$ & - & - & $\mathrm{T} / \mathrm{l}$ \\
\hline I-125 (Methyl) ..... & $2 E-08$ & - & - & $9 \mathrm{E}+02$ & - & - & $\mathrm{T} / 2$ \\
\hline I-125 (Vapor) ....... & - & $2 E-08$ & - & - & $7 E+02$ & - & $/ \mathrm{T} /$ \\
\hline $\mathrm{I}-125$ & $3 E-08$ & - & - & $1 \mathrm{E}+03$ & - & - & $\mathrm{T} / \mathrm{l}$ \\
\hline I-126 (Methyl) ..... & $1 E-08$ & - & - & $5 \mathrm{E}+02$ & - & - & $\mathrm{T} / \mathrm{l}$ \\
\hline I-126 (Vapor) ....... & - & $1 E-08$ & - & - & $4 \mathrm{E}+02$ & - & $/ \mathrm{T} /$ \\
\hline $\mathrm{I}-126$ & $2 E-08$ & - & - & $7 \mathrm{E}+02$ & - & _- & $\mathrm{T} / \mathrm{l}$ \\
\hline I-128 (Methyl) ..... & $3 E-05$ & - & - & $1 \mathrm{E}+06$ & - & - & $\mathrm{T} / /$ \\
\hline I-128 (Vapor) ....... & - & $8 E-06$ & - & - & $3 E+05$ & - & /St/ \\
\hline I-128 & $1 E-05$ & - & - & $6 \mathrm{E}+05$ & - & _- & $\mathrm{ET} / /$ \\
\hline I-129 (Methyl) ..... & $3 E-09$ & - & - & $1 \mathrm{E}+02$ & - & - & $\mathrm{T} / \mathrm{l}$ \\
\hline I-129 (Vapor) ....... & - & $2 E-09$ & - & - & $1 \mathrm{E}+02$ & - & $/ \mathrm{T} /$ \\
\hline $\mathrm{I}-129$ & $5 E-09$ & - & - & $2 \mathrm{E}+02$ & - & - & $\mathrm{T} / \mathrm{l}$ \\
\hline I-130 (Methyl) ..... & $2 E-07$ & - & - & $7 \mathrm{E}+03$ & - & - & $\mathrm{T} / \mathrm{l}$ \\
\hline $\mathrm{I}-130$ (Vapor) ....... & - & $1 \mathrm{E}-07$ & - & - & $6 \mathrm{E}+03$ & - & $/ \mathrm{T} /$ \\
\hline $\mathrm{I}-130$ & $3 E-07$ & - & - & $1 \mathrm{E}+04$ & - & - & $\mathrm{T} / \mathrm{l}$ \\
\hline I-131 (Methyl) ...... & $1 \mathrm{E}-08$ & - & - & $6 \mathrm{E}+02$ & - & _- & $\mathrm{T} / \mathrm{l}$ \\
\hline I-131 (Vapor) ...... & - & $1 \mathrm{E}-08$ & - & - & $5 \mathrm{E}+02$ & - & $/ \mathrm{T} /$ \\
\hline $\mid-131 \ldots \ldots \ldots \ldots \ldots$ & $2 E-08$ & - & - & $9 \mathrm{E}+02$ & - & - & $\mathrm{T} / \mathrm{l}$ \\
\hline I-132m (Methyl) .. & $1 E-06$ & - & - & $7 \mathrm{E}+04$ & - & _- & $\mathrm{T} / \mathrm{l}$ \\
\hline I-132m (Vapor) ... & - & $1 E-06$ & - & - & $6 \mathrm{E}+04$ & - & $/ \mathrm{T} /$ \\
\hline $\mathrm{l}-132 \mathrm{~m}$ & $3 E-06$ & - & - & $1 \mathrm{E}+05$ & - & - & $\mathrm{T} / \mathrm{l}$ \\
\hline l-132 (Methyl) ..... & $1 \mathrm{E}-06$ & - & - & $6 \mathrm{E}+04$ & - & _- & $\mathrm{T} / \mathrm{l}$ \\
\hline I-132 (Vapor) ....... & - & $1 E-06$ & - & - & $5 \mathrm{E}+04$ & - & $/ \mathrm{T} /$ \\
\hline $\mathrm{I}-132$ & $2 E-06$ & - & - & $7 \mathrm{E}+04$ & - & - & $\mathrm{T} / \mathrm{l}$ \\
\hline l-133 (Methyl) ..... & $9 \mathrm{E}-08$ & - & - & $3 \mathrm{E}+03$ & - & _- & $\mathrm{T} / \mathrm{l}$ \\
\hline I-133 (Vapor) ....... & - & $7 E-08$ & - & - & $2 E+03$ & _- & $/ \mathrm{T} /$ \\
\hline $\mathrm{I}-133$..................... & $1 E-07$ & - & - & $5 \mathrm{E}+03$ & - & - & $\mathrm{T} / \mathrm{l}$ \\
\hline I-134 (Methyl) ...... & $8 \mathrm{E}-06$ & - & - & $2 \mathrm{E}+05$ & - & - & $\mathrm{T} / \mathrm{l}$ \\
\hline I-134 (Vapor) ....... & - & $3 E-06$ & - & - & $1 E+05$ & - & $/ \mathrm{St} /$ \\
\hline $\mathrm{l}-134$ & $3 E-06$ & - & - & $1 \mathrm{E}+05$ & - & - & $\mathrm{ET} / / /$ \\
\hline I-135 (Methyl) ..... & $4 \mathrm{E}-07$ & - & - & $1 \mathrm{E}+04$ & - & - & $\mathrm{T} / \mathrm{l}$ \\
\hline I-135 (Vapor) ....... & - & $3 E-07$ & - & - & $1 E+04$ & - & $/ \mathrm{T} /$ \\
\hline $\mathrm{I}-135 \ldots \ldots \ldots \ldots \ldots \ldots$ & $6 \mathrm{E}-07$ & - & - & $2 \mathrm{E}+04$ & - & - & $\mathrm{T} / \mathrm{l}$ \\
\hline Cs-125 …….......... & $1 E-05$ & - & - & $4 \mathrm{E}+05$ & - & - & $\mathrm{ET} / /$ \\
\hline Cs-127 … & $4 \mathrm{E}-06$ & - & - & $1 \mathrm{E}+05$ & - & - & $\mathrm{ET} / /$ \\
\hline Cs-129 ............ & $2 E-06$ & - & - & $9 \mathrm{E}+04$ & _- & _- & $\mathrm{ET} /$ / \\
\hline Cs-130 …….......... & $1 E-05$ & - & - & $6 \mathrm{E}+05$ & - & - & $\mathrm{ET} / /$ \\
\hline Cs-131 … & $7 E-06$ & - & - & $2 E+05$ & - & - & $\mathrm{ET} / /$ \\
\hline Cs-132 …............. & $9 \mathrm{E}-07$ & - & - & $3 \mathrm{E}+04$ & - & - & $\mathrm{ET} /$ / \\
\hline Cs-134m ……...... & $8 E-06$ & - & - & $2 \mathrm{E}+05$ & - & - & $\mathrm{ET} / / /$ \\
\hline Cs-134 … & $5 E-08$ & - & - & $2 E+03$ & - & - & St/ / \\
\hline Cs-135m ................ & $8 \mathrm{E}-06$ & - & - & $2 \mathrm{E}+05$ & - & - & $\mathrm{ET} / /$ \\
\hline Cs-135 ……........... & $5 E-07$ & - & - & $2 E+04$ & - & - & St/ / \\
\hline Cs-136 …….......... & $2 E-07$ & - & - & $1 \mathrm{E}+04$ & - & - & E/ / \\
\hline Cs-137 …............... & $8 \mathrm{E}-08$ & - & - & $3 E+03$ & - & - & $\mathrm{St} / \mathrm{I}$ \\
\hline Cs-138 ……........... & $5 E-06$ & - & - & $2 \mathrm{E}+05$ & - & - & $\mathrm{ET} / /$ \\
\hline Ba-126 .................. & $4 \mathrm{E}-06$ & - & - & $1 \mathrm{E}+05$ & - & - & $\mathrm{ET} / /$ \\
\hline Ba-128 …............... & $4 \mathrm{E}-07$ & - & - & $1 \mathrm{E}+04$ & - & - & St/ / \\
\hline Ba-131m ................. & $4 E-05$ & - & - & $1 \mathrm{E}+06$ & - & - & $\mathrm{ET} / /$ \\
\hline Ba-131 ................... & $1 \mathrm{E}-06$ & - & - & $4 \mathrm{E}+04$ & - & - & $\mathrm{ET} /$ / \\
\hline Ba-133m ................ & $2 E-06$ & - & - & $7 \mathrm{E}+04$ & - & - & St/ / \\
\hline Ba-133 ….............. & $3 E-07$ & - & - & $1 \mathrm{E}+04$ & - & - & St/ / \\
\hline $\mathrm{Ba}-135 \mathrm{~m}$ & $2 E-06$ & - & - & $9 \mathrm{E}+04$ & - & - & St/ / \\
\hline Ва-139 ……........... & $1 E-05$ & - & - & $3 E+05$ & - & - & St/ / \\
\hline Ba-140 ................. & $3 E-07$ & - & - & $1 \mathrm{E}+04$ & - & - & St/ / \\
\hline Ba-141 ……......... & $1 E-05$ & - & - & $4 \mathrm{E}+05$ & - & - & $\mathrm{ET} / /$ \\
\hline
\end{tabular}


Pt. 835, App. A

10 CFR Ch. III (1-1-08 Edition)

\begin{tabular}{|c|c|c|c|c|c|c|c|}
\hline \multirow{3}{*}{ Radionuclide } & \multicolumn{3}{|c|}{ Absorption type ${ }^{3}$} & \multicolumn{3}{|c|}{ Absorption type ${ }^{3}$} & \multirow{3}{*}{$\begin{array}{c}\begin{array}{c}\text { Stochastic or } \\
\text { organ or tis- } \\
\text { sue }^{1}\end{array} \\
(\mathrm{~F} / \mathrm{M} / \mathrm{S})\end{array}$} \\
\hline & \multicolumn{3}{|c|}{$\mu \mathrm{Ci} / \mathrm{mL}$} & \multicolumn{3}{|c|}{$\mathrm{Bq} / \mathrm{m}^{3}$} & \\
\hline & $\mathrm{F}$ & M & $S$ & $\mathrm{~F}$ & $M$ & $S$ & \\
\hline Ba-142 …............... & $9 E-06$ & - & - & $3 \mathrm{E}+05$ & - & _- & $\mathrm{ET} /$ / \\
\hline La-131 .................... & $1 E-05$ & $8 E-06$ & - & $4 \mathrm{E}+05$ & $3 \mathrm{E}+05$ & - & ET/ET/ \\
\hline La-132 ….................. & $1 E-06$ & $1 \mathrm{E}-06$ & - & $5 \mathrm{E}+04$ & $5 \mathrm{E}+04$ & - & $\mathrm{ET} / \mathrm{ET} /$ \\
\hline La-135 ................... & $1 \bar{E}-05$ & $1 \mathrm{E}-05$ & - & $4 \mathrm{E}+05$ & $4 \mathrm{E}+05$ & - & $\mathrm{ET} / \mathrm{ET} /$ \\
\hline La-137 ..................... & $4 E-08$ & $2 E-07$ & - & $1 \mathrm{E}+03$ & $8 \mathrm{E}+03$ & - & L/L/ \\
\hline La-138 ...................... & $3 E-09$ & $1 E-08$ & - & $1 \mathrm{E}+02$ & $4 \mathrm{E}+02$ & - & $\mathrm{St} / \mathrm{St} /$ \\
\hline La-140 ..................... & $4 \mathrm{E}-07$ & $3 E-07$ & - & $1 \mathrm{E}+04$ & $1 \mathrm{E}+04$ & - & $\mathrm{ET} / \mathrm{St} /$ \\
\hline La-141 ................... & $5 E-06$ & $2 E-06$ & - & $1 \mathrm{E}+05$ & $9 \mathrm{E}+04$ & - & $\mathrm{St} / \mathrm{St} /$ \\
\hline La-142 …................... & $2 E-06$ & $2 E-06$ & - & $9 \mathrm{E}+04$ & $8 E+04$ & - & $\mathrm{ET} / \mathrm{ET} /$ \\
\hline La-143 .................... & $1 E-05$ & $1 E-05$ & - & $6 \mathrm{E}+05$ & $4 E+05$ & - & $\mathrm{ET} / \mathrm{ET} /$ \\
\hline $\mathrm{Ce}-134$.................... & - & $3 E-07$ & $3 E-07$ & - & $1 \mathrm{E}+04$ & $1 E+04$ & $/ \mathrm{St} / \mathrm{St}$ \\
\hline Ce-135 ……............ & - & $5 E-07$ & $5 E-07$ & - & $2 \mathrm{E}+04$ & $2 E+04$ & /ET/ET \\
\hline $\mathrm{Ce}-137 \mathrm{~m} \ldots \ldots \ldots \ldots \ldots$ & - & $1 E-06$ & $9 E-07$ & - & $3 E+04$ & $3 E+04$ & $/ \mathrm{St} / \mathrm{St}$ \\
\hline $\mathrm{Ce}-137 \ldots \ldots \ldots \ldots \ldots$ & - & $1 E-05$ & $1 E-05$ & - & $7 \mathrm{E}+05$ & $7 E+05$ & /ET/ET \\
\hline Ce-139 …….......... & - & $4 \mathrm{E}-07$ & $4 E-07$ & - & $1 \mathrm{E}+04$ & $1 \mathrm{E}+04$ & $/ \mathrm{St} / \mathrm{St}$ \\
\hline $\mathrm{Ce}-141 \ldots \ldots \ldots \ldots \ldots$ & - & $2 E-07$ & $1 \mathrm{E}-07$ & - & $7 E+03$ & $6 \mathrm{E}+03$ & $/ \mathrm{St} / \mathrm{St}$ \\
\hline $\mathrm{Ce}-143$ & - & $5 E-07$ & $5 E-07$ & - & $2 \mathrm{E}+04$ & $2 E+04$ & $/ \mathrm{St} / \mathrm{St}$ \\
\hline $\mathrm{Ce}-144$ & - & $2 E-08$ & $1 E-08$ & - & $9 \mathrm{E}+02$ & $7 E+02$ & $/ \mathrm{St} / \mathrm{St}$ \\
\hline Pr-136 …….............. & - & $1 E-05$ & $1 E-05$ & - & $3 E+05$ & $3 \mathrm{E}+05$ & /ET/ET \\
\hline Pr-137 ..................... & - & $9 \bar{E}-06$ & $9 E-06$ & - & $3 E+05$ & $3 E+05$ & /ET/ET \\
\hline Pr-138m .................. & - & $2 E-06$ & $2 E-06$ & - & $7 \mathrm{E}+04$ & $7 E+04$ & /ET/ET \\
\hline Pr-139 ……............. & - & $1 E-05$ & $1 \mathrm{E}-05$ & - & $5 \mathrm{E}+05$ & $5 \mathrm{E}+05$ & /ET/ET \\
\hline Pr-142m …….......... & - & $6 E-05$ & $5 E-05$ & - & $2 \mathrm{E}+06$ & $2 \mathrm{E}+06$ & $/ \mathrm{St} / \mathrm{St}$ \\
\hline Pr-142 …….............. & - & $8 E-07$ & $7 E-07$ & - & $2 \mathrm{E}+04$ & $2 E+04$ & $/ \mathrm{St} / \mathrm{St}$ \\
\hline Pr-143 ……............ & - & $2 E-07$ & $2 E-07$ & - & $1 \mathrm{E}+04$ & $9 \mathrm{E}+03$ & $/ \mathrm{St} / \mathrm{St}$ \\
\hline Pr-144 ……............ & - & $1 E-05$ & $1 \mathrm{E}-05$ & - & $4 \mathrm{E}+05$ & $4 \mathrm{E}+05$ & /ET/ET \\
\hline Pr-145 ……............ & - & $2 E-06$ & $2 E-06$ & - & $8 \mathrm{E}+04$ & $8 \mathrm{E}+04$ & $/ \mathrm{St} / \mathrm{St}$ \\
\hline Pr-147 ……............ & - & $9 E-06$ & $9 E-06$ & - & $3 E+05$ & $3 E+05$ & /ET/ET \\
\hline $\mathrm{Nd}-136 \ldots \ldots \ldots \ldots \ldots$ & - & $4 E-06$ & $4 E-06$ & - & $1 \mathrm{E}+05$ & $1 \mathrm{E}+05$ & /ET/ET \\
\hline $\mathrm{Nd}-138 \ldots \ldots \ldots \ldots \ldots$ & - & $1 E-06$ & $1 \mathrm{E}-06$ & - & $5 E+04$ & $5 E+04$ & $/ \mathrm{St} / \mathrm{St}$ \\
\hline $\mathrm{Nd}-139 \mathrm{~m}$ & - & $1 E-06$ & $1 \mathrm{E}-06$ & _- & $5 \mathrm{E}+04$ & $5 E+04$ & /ET/ET \\
\hline $\mathrm{Nd}-139$ & - & $1 E-05$ & $1 \mathrm{E}-05$ & - & $6 \mathrm{E}+05$ & $6 \mathrm{E}+05$ & /ET/ET \\
\hline $\mathrm{Nd}-141 \ldots \ldots \ldots \ldots \ldots$ & - & $3 E-05$ & $3 E-05$ & - & $1 \mathrm{E}+06$ & $1 \mathrm{E}+06$ & /ET/ET \\
\hline $\mathrm{Nd}-147 \ldots \ldots \ldots \ldots \ldots$ & - & $2 E-07$ & $2 E-07$ & - & $1 \mathrm{E}+04$ & $9 \mathrm{E}+03$ & $/ \mathrm{St} / \mathrm{St}$ \\
\hline Nd-149 ……........... & - & $4 \mathrm{E}-06$ & $4 E-06$ & - & $1 \mathrm{E}+05$ & $1 E+05$ & /ET/ET \\
\hline $\mathrm{Nd}-151 \ldots \ldots \ldots \ldots \ldots$ & - & $9 E-06$ & $9 E-06$ & - & $3 E+05$ & $3 E+05$ & /ET/ET \\
\hline Pm-141 .................. & - & $1 \bar{E}-05$ & $1 E-05$ & - & $4 \mathrm{E}+05$ & $4 \mathrm{E}+05$ & /ET/ET \\
\hline Pm-143 …….......... & - & $5 E-07$ & $6 \mathrm{E}-07$ & - & $2 \mathrm{E}+04$ & $2 E+04$ & $/ \mathrm{St} / \mathrm{St}$ \\
\hline Pm-144 ……......... & - & $1 E-07$ & $1 \mathrm{E}-07$ & - & $3 \mathrm{E}+03$ & $5 \mathrm{E}+03$ & $/ \mathrm{St} / \mathrm{St}$ \\
\hline Pm-145 .................. & - & $1 E-07$ & $4 \mathrm{E}-07$ & - & $5 \mathrm{E}+03$ & $1 \mathrm{E}+04$ & /BS/St \\
\hline Pm-146 & - & $4 E-08$ & $6 E-08$ & - & $1 \mathrm{E}+03$ & $2 E+03$ & $/ \mathrm{St} / \mathrm{St}$ \\
\hline Pm-147 ….............. & - & $1 E-07$ & $1 \mathrm{E}-07$ & - & $4 \mathrm{E}+03$ & $6 \mathrm{E}+03$ & /BS/St \\
\hline $\mathrm{Pm}-148 \mathrm{~m}$ & - & $1 E-07$ & $1 \mathrm{E}-07$ & - & $5 \mathrm{E}+03$ & $4 \mathrm{E}+03$ & $/ \mathrm{St} / \mathrm{St}$ \\
\hline Pm-148 ……............ & - & $2 E-07$ & $2 E-07$ & - & $9 \mathrm{E}+03$ & $9 \mathrm{E}+03$ & $/ \mathrm{St} / \mathrm{St}$ \\
\hline Pm-149 …….......... & - & $7 E-07$ & $6 \mathrm{E}-07$ & - & $2 \mathrm{E}+04$ & $2 \mathrm{E}+04$ & $/ \mathrm{St} / \mathrm{St}$ \\
\hline Pm-150 …............... & - & $2 E-06$ & $2 E-06$ & - & $8 \mathrm{E}+04$ & $8 \mathrm{E}+04$ & $/ E T / E T$ \\
\hline Pm-151 .................. & - & $9 \mathrm{E}-07$ & $8 \mathrm{E}-07$ & - & $3 E+04$ & $3 E+04$ & $/ \mathrm{St} / \mathrm{St}$ \\
\hline $\mathrm{Sm}-141 \mathrm{~m} \quad \ldots \ldots \ldots \ldots$ & - & $5 E-06$ & - & - & $2 \mathrm{E}+05$ & - & $/ \mathrm{ET} /$ \\
\hline Sm-141 & - & $1 E-05$ & - & - & $4 \mathrm{E}+05$ & - & /ET/ \\
\hline $\mathrm{Sm}-142 \ldots \ldots \ldots \ldots \ldots$ & - & $4 \mathrm{E}-06$ & - & - & $1 \mathrm{E}+05$ & - & /ET/ \\
\hline Sm-145 ….............. & - & $4 \mathrm{E}-07$ & - & - & $1 \mathrm{E}+04$ & - & /BS/ \\
\hline $\mathrm{Sm}-146 \quad \ldots \ldots \ldots \ldots \ldots \ldots$ & - & $2 E-11$ & - & - & $1 \mathrm{E}+00$ & - & /BS/ \\
\hline $\mathrm{Sm}-147 \ldots \ldots \ldots \ldots \ldots$ & - & $2 E-11$ & - & - & $1 \mathrm{E}+00$ & - & /BS/ \\
\hline Sm-151 ................ & - & $7 \mathrm{E}-08$ & - & - & $2 \mathrm{E}+03$ & - & /BS/ \\
\hline Sm-153 & - & $8 \mathrm{E}-07$ & - & - & $3 E+04$ & - & $/ \mathrm{St} /$ \\
\hline $\mathrm{Sm}-155$ & - & $1 E-05$ & - & - & $3 E+05$ & - & /ET/ \\
\hline Sm-156 & - & $2 \bar{E}-06$ & - & - & $7 \mathrm{E}+04$ & - & $/ \mathrm{St} /$ \\
\hline Eu-145 ….............. & - & $5 E-07$ & - & - & $2 E+04$ & - & /ET/ \\
\hline Eu-146 ................. & - & $3 E-07$ & - & - & $1 \mathrm{E}+04$ & - & /ET/ \\
\hline Eu-147 .................. & - & $5 \bar{E}-07$ & - & - & $2 \mathrm{E}+04$ & - & $/ \mathrm{St} /$ \\
\hline Eu-148 .................. & - & $2 E-07$ & - & - & $9 \mathrm{E}+03$ & - & $/ \mathrm{St} /$ \\
\hline Eu-149 …............. & - & $2 E-06$ & - & - & $9 \mathrm{E}+04$ & - & $/ \mathrm{St} /$ \\
\hline Eu-150 (12 h) ..... & - & $2 E-06$ & - & - & $7 \mathrm{E}+04$ & - & $/ \mathrm{St} /$ \\
\hline Eu-150 (34 yr) .... & - & $1 E-08$ & - & - & $6 \mathrm{E}+02$ & - & $/ \mathrm{St} /$ \\
\hline Eu-152m ................. & - & $1 \bar{E}-06$ & - & - & $6 \mathrm{E}+04$ & - & /St/ \\
\hline Eu-152 …….......... & - & $2 E-08$ & - & - & $7 \mathrm{E}+02$ & - & /St/ \\
\hline Eu-154 …............. & - & $1 E-08$ & - & - & $5 \mathrm{E}+02$ & - & $/ \mathrm{St} /$ \\
\hline 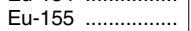 & - & $7 E-08$ & - & - & $2 \mathrm{E}+03$ & - & /BS/ \\
\hline Eu-156 …….......... & - & $1 E-07$ & - & - & $6 \mathrm{E}+03$ & - & $/ \mathrm{St} /$ \\
\hline Eu-157 ................ & - & $1 E-06$ & - & - & $4 \mathrm{E}+04$ & - & $/ \mathrm{St} /$ \\
\hline Eu-158 $\ldots \ldots \ldots \ldots \ldots$ & - & $5 \mathrm{E}-6$ & - & - & $1 \mathrm{E}+05$ & - & /ET/ \\
\hline
\end{tabular}


Department of Energy

Pt. 835, App. A

\begin{tabular}{|c|c|c|c|c|c|c|c|}
\hline \multirow{3}{*}{ Radionuclide } & \multicolumn{3}{|c|}{ Absorption type ${ }^{3}$} & \multicolumn{3}{|c|}{ Absorption type ${ }^{3}$} & \multirow{3}{*}{$\begin{array}{c}\begin{array}{c}\text { Stochastic or } \\
\text { organ or tis- } \\
\text { sue }^{1}\end{array} \\
(\mathrm{~F} / \mathrm{M} / \mathrm{S})\end{array}$} \\
\hline & \multicolumn{3}{|c|}{$\mu \mathrm{Ci} / \mathrm{mL}$} & \multicolumn{3}{|c|}{$\mathrm{Bq} / \mathrm{m}^{3}$} & \\
\hline & $\mathrm{F}$ & $M$ & $S$ & $\mathrm{~F}$ & M & $S$ & \\
\hline Gd-145 ...................... & $9 E-06$ & $7 E-06$ & - & $3 E+05$ & $2 E+05$ & - & $\mathrm{ET} / \mathrm{ET} /$ \\
\hline Gd-146 .................... & $1 E-07$ & $1 \mathrm{E}-07$ & - & $4 \mathrm{E}+03$ & $4 \mathrm{E}+03$ & - & $\mathrm{St} / \mathrm{St} /$ \\
\hline Gd-147 …............... & $7 E-07$ & $6 E-07$ & - & $2 \mathrm{E}+04$ & $2 \mathrm{E}+04$ & - & $\mathrm{ET} / \mathrm{ET} /$ \\
\hline Gd-148 & $5 E-12$ & $2 E-11$ & - & $2 E-01$ & $9 E-01$ & - & $\mathrm{BS} / \mathrm{BS} /$ \\
\hline Gd-149 ….................. & $1 \mathrm{E}-06$ & $7 \mathrm{E}-07$ & - & $4 \mathrm{E}+04$ & $2 E+04$ & - & $\mathrm{St} / \mathrm{St} /$ \\
\hline Gd-151 ................... & $2 E-07$ & $8 E-07$ & - & $9 \mathrm{E}+03$ & $3 E+04$ & - & $\mathrm{BS} / \mathrm{St} /$ \\
\hline Gd-152 .................... & $7 E-12$ & $3 E-11$ & - & $2 E-01$ & $1 \mathrm{E}+00$ & - & BS/BS/ \\
\hline Gd-153 ….................. & $9 E-08$ & $4 E-07$ & - & $3 E+03$ & $1 E+04$ & - & $\mathrm{BS} / \mathrm{St} /$ \\
\hline Gd-159 …................ & $3 E-06$ & $1 \mathrm{E}-06$ & - & $1 \mathrm{E}+05$ & $5 \mathrm{E}+04$ & - & $\mathrm{St} / \mathrm{St} /$ \\
\hline Tb-147 …............... & - & $2 E-06$ & - & - & $1 \mathrm{E}+05$ & - & $/ \mathrm{ET} /$ \\
\hline Tb-149 ……........... & - & $1 \mathrm{E}-07$ & - & - & $6 \mathrm{E}+03$ & - & /St/ \\
\hline Tb-150 …................ & - & $2 E-06$ & - & - & $8 \mathrm{E}+04$ & - & /ET/ \\
\hline Tb-151 …............. & - & $1 E-06$ & - & - & $4 \mathrm{E}+04$ & - & /ET/ \\
\hline Tb-153 …............... & - & $2 \bar{E}-06$ & - & - & $8 E+04$ & - & /St/ \\
\hline Tb-154 ….............. & - & $5 E-07$ & - & - & $2 E+04$ & - & /ET/ \\
\hline Tb-155 …….............. & - & $2 E-06$ & - & - & $8 E+04$ & - & /St/ \\
\hline Tb-156m $(24 \mathrm{~h}) \ldots$ & - & $2 E-06$ & - & - & $9 \mathrm{E}+04$ & - & /St/ \\
\hline Tb-156m (5 h) ..... & - & $4 \mathrm{E}-06$ & - & - & $1 \mathrm{E}+05$ & - & /St/ \\
\hline Tb-156 .................... & - & $4 \mathrm{E}-07$ & - & - & $1 \mathrm{E}+04$ & - & /E/ \\
\hline Tb-157 ……............ & - & $2 \bar{E}-07$ & - & - & $8 \mathrm{E}+03$ & - & /BS/ \\
\hline Tb-158 & - & $1 E-08$ & - & - & $6 \mathrm{E}+02$ & - & /BS/ \\
\hline Tb-160 ….............. & - & $1 E-07$ & - & - & $3 E+03$ & - & /St/ \\
\hline Tb-161 …............... & - & $4 E-07$ & - & - & $1 E+04$ & - & /St/ \\
\hline Dy-155 ................... & - & $2 E-06$ & - & - & $1 \mathrm{E}+05$ & - & /ET/ \\
\hline Dy-157 $\ldots \ldots \ldots \ldots \ldots$ & - & $5 E-06$ & - & - & $1 \mathrm{E}+05$ & - & /ET/ \\
\hline Dy-159 …................. & - & $2 E-06$ & - & - & $8 \mathrm{E}+04$ & - & /BS/ \\
\hline Dy-165 ..................... & - & $6 \bar{E}-06$ & - & - & $2 \mathrm{E}+05$ & - & /ET/ \\
\hline 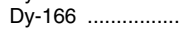 & - & $3 E-07$ & - & - & $1 \mathrm{E}+04$ & - & $/ \mathrm{St} /$ \\
\hline Ho-155 ..................... & - & $1 \mathrm{E}-05$ & - & - & $4 E+05$ & - & /ET/ \\
\hline Ho-157 .................. & - & $2 E-05$ & - & - & $1 \mathrm{E}+06$ & - & /ET/ \\
\hline Ho-159 ............. & - & $2 E-05$ & - & - & $9 E+05$ & - & /ET/ \\
\hline Ho-161 ...................... & - & $3 E-05$ & - & - & $1 E+06$ & - & /ET/ \\
\hline Ho-162m ................. & - & $9 E-06$ & - & - & $3 E+05$ & - & /ET/ \\
\hline Ho-162 ................... & - & $5 \bar{E}-05$ & - & - & $2 E+06$ & - & /ET/ \\
\hline Ho-164m ................. & - & $3 E-05$ & - & - & $1 E+06$ & - & $/ \mathrm{St} /$ \\
\hline Ho-164 .................. & - & $2 E-05$ & - & - & $8 \mathrm{E}+05$ & - & /ET/ \\
\hline Ho-166m ................ & - & $7 E-09$ & - & - & $2 E+02$ & - & $/ \mathrm{St} /$ \\
\hline Нo-166 .................. & - & $6 E-07$ & - & - & $2 E+04$ & - & $/ \mathrm{St} /$ \\
\hline Ho-167 ................... & - & $4 E-06$ & - & - & $1 \mathrm{E}+05$ & - & /ET/ \\
\hline Er-161 …................ & - & $3 E-06$ & - & - & $1 \mathrm{E}+05$ & - & /ET/ \\
\hline Er-165 …................. & - & $2 E-05$ & - & - & $1 \mathrm{E}+06$ & - & /ET/ \\
\hline Er-169 ……............. & - & $6 E-07$ & - & - & $2 \mathrm{E}+04$ & - & $/ \mathrm{St} /$ \\
\hline Er-171 ……............. & - & $1 E-06$ & - & - & $6 \mathrm{E}+04$ & - & $/ \mathrm{St} /$ \\
\hline Er-172 …................... & - & $4 \mathrm{E}-07$ & - & - & $1 E+04$ & - & $/ \mathrm{St} /$ \\
\hline Tm-162 …................ & - & $9 E-06$ & - & - & $3 E+05$ & - & /ET/ \\
\hline Tm-166 …….......... & - & $1 E-06$ & - & - & $4 \mathrm{E}+04$ & - & /ET/ \\
\hline Tm-167 & - & $5 \bar{E}-07$ & - & - & $2 E+04$ & - & $/ \mathrm{St} /$ \\
\hline $\mathrm{Tm}-170$ & - & $1 E-07$ & - & - & $4 \mathrm{E}+03$ & - & $/ \mathrm{St} /$ \\
\hline Tm-171 ……......... & - & $2 E-07$ & - & - & $9 \mathrm{E}+03$ & - & /BS/ \\
\hline Tm-172 …................ & - & $4 E-07$ & - & - & $1 \mathrm{E}+04$ & - & $/ \mathrm{St} /$ \\
\hline $\mathrm{Tm}-173$ & - & $2 E-06$ & - & - & $8 E+04$ & - & $/ \mathrm{St} /$ \\
\hline $\mathrm{Tm}-175$ & - & $8 \bar{E}-06$ & - & - & $2 E+05$ & - & /ET/ \\
\hline Yb-162 …................. & - & $1 E-05$ & $1 E-05$ & - & $5 E+05$ & $5 E+05$ & /ET/ET \\
\hline Yb-166 ....................... & - & $6 \bar{E}-07$ & $5 \mathrm{E}-07$ & - & $2 E+04$ & $2 E+04$ & $/ \mathrm{St} / \mathrm{St}$ \\
\hline Yb-167 .................... & - & $3 \bar{E}-05$ & $3 E-05$ & - & $1 E+06$ & $1 E+06$ & /ET/ET \\
\hline Yb-169 .................... & - & $2 E-07$ & $2 E-07$ & - & $9 \mathrm{E}+03$ & $8 \mathrm{E}+03$ & $/ \mathrm{St} / \mathrm{St}$ \\
\hline Yb-175 .................... & - & $8 \bar{E}-07$ & $8 \mathrm{E}-07$ & - & $3 E+04$ & $2 E+04$ & $/ \mathrm{St} / \mathrm{St}$ \\
\hline Yb-177 ..................... & - & $6 E-06$ & $5 E-06$ & - & $2 E+05$ & $2 E+05$ & /ET/ET \\
\hline Yb-178 ....................... & - & $5 E-06$ & $5 E-06$ & - & $1 E+05$ & $1 \mathrm{E}+05$ & $/ \mathrm{ET} / \mathrm{E}$ \\
\hline Lu-169 ................... & - & $9 \bar{E}-07$ & $9 \bar{E}-07$ & - & $3 E+04$ & $3 E+04$ & /ET/ET \\
\hline Lu-170 ................... & - & $4 E-07$ & $4 E-07$ & - & $1 E+04$ & $1 E+04$ & /ET/ET \\
\hline Lu-171 ................... & - & $6 E-07$ & $6 \mathrm{E}-07$ & - & $2 E+04$ & $2 E+04$ & $/ \mathrm{St} / \mathrm{St}$ \\
\hline Lu-172 …................. & - & $3 E-07$ & $3 E-07$ & - & $1 \mathrm{E}+04$ & $1 \mathrm{E}+04$ & $/ \mathrm{St} / \mathrm{St}$ \\
\hline Lu-173 …................ & - & $2 E-07$ & $4 E-07$ & - & $8 \mathrm{E}+03$ & $1 \mathrm{E}+04$ & /BS/St \\
\hline Lu-174m ................. & - & $2 E-07$ & $2 E-07$ & - & $7 E+03$ & $8 \mathrm{E}+03$ & /BS/St \\
\hline Lu-174 ……............ & - & $9 \mathrm{E}-08$ & $2 E-07$ & - & $3 \mathrm{E}+03$ & $8 \mathrm{E}+03$ & /BS/St \\
\hline Lu-176m .................. & - & $3 E-06$ & $3 E-06$ & - & $1 \mathrm{E}+05$ & $1 \mathrm{E}+05$ & $/ \mathrm{St} / \mathrm{St}$ \\
\hline Lu-176 ..................... & - & $3 E-09$ & $1 E-08$ & - & $1 E+02$ & $6 \mathrm{E}+02$ & /BS/St \\
\hline Lu-177m ................ & - & $5 E-08$ & $4 E-08$ & - & $2 \mathrm{E}+03$ & $1 \mathrm{E}+03$ & $/ \mathrm{St} / \mathrm{St}$ \\
\hline Lu-177 …............... & - & $5 E-07$ & $5 E-07$ & - & $2 E+04$ & $1 \mathrm{E}+04$ & $/ \mathrm{St} / \mathrm{St}$ \\
\hline Lu-178m ................. & - & $4 \mathrm{E}-06$ & $4 \mathrm{E}-06$ & - & $1 \mathrm{E}+05$ & $1 \mathrm{E}+05$ & /ET/ET \\
\hline
\end{tabular}


Pt. 835, App. A

10 CFR Ch. III (1-1-08 Edition)

\begin{tabular}{|c|c|c|c|c|c|c|c|}
\hline \multirow{3}{*}{ Radionuclide } & \multicolumn{3}{|c|}{ Absorption type ${ }^{3}$} & \multicolumn{3}{|c|}{ Absorption type ${ }^{3}$} & \multirow{2}{*}{$\begin{array}{l}\text { Stochastic or } \\
\text { organ or tis- } \\
\text { sue } 1\end{array}$} \\
\hline & \multicolumn{3}{|c|}{$\mu \mathrm{Ci} / \mathrm{mL}$} & \multicolumn{3}{|c|}{$\mathrm{Bq} / \mathrm{m}^{3}$} & \\
\hline & $\mathrm{F}$ & M & $S$ & $\mathrm{~F}$ & M & s & $(\mathrm{F} / \mathrm{M} / \mathrm{S})$ \\
\hline Lu-178 ……............... & - & $8 \mathrm{E}-06$ & $8 E-06$ & - & $3 E+05$ & $3 \mathrm{E}+05$ & /ET/ET \\
\hline Lu-179 ……............. & - & $3 E-06$ & $3 E-06$ & - & $1 \mathrm{E}+05$ & $1 \mathrm{E}+05$ & $/ \mathrm{St} / \mathrm{St}$ \\
\hline Hf-170 ……........... & $1 \mathrm{E}-06$ & $1 E-06$ & - & $4 \mathrm{E}+04$ & $4 \mathrm{E}+04$ & - & $\mathrm{ET} / \mathrm{ET} /$ \\
\hline $\mathrm{Hf}-172 \ldots \ldots \ldots \ldots \ldots$ & $6 \bar{E}-09$ & $3 E-08$ & - & $2 \mathrm{E}+02$ & $1 \mathrm{E}+03$ & - & $\mathrm{BS} / \mathrm{BS} /$ \\
\hline $\mathrm{Hf}-173$.......................... & $2 E-06$ & $2 E-06$ & - & $9 \mathrm{E}+04$ & $8 \mathrm{E}+04$ & - & $\mathrm{ET} / \mathrm{ET} /$ \\
\hline $\mathrm{Hf}-175 \ldots \ldots \ldots \ldots \ldots$ & $5 E-07$ & $6 E-07$ & - & $2 E+04$ & $2 E+04$ & - & $\mathrm{BS} / \mathrm{St} /$ \\
\hline $\mathrm{Hf}-177 \mathrm{~m}$ & $2 E-06$ & $1 E-06$ & - & $9 E+04$ & $6 E+04$ & - & $\mathrm{ET} / \mathrm{ET} /$ \\
\hline $\mathrm{Hf}-178 \mathrm{~m}$ & $8 \mathrm{E}-10$ & $4 E-09$ & - & $3 E+01$ & $1 \mathrm{E}+02$ & - & $\mathrm{BS} / \mathrm{BS} /$ \\
\hline $\mathrm{Hf}-179 \mathrm{~m} \ldots \ldots \ldots \ldots \ldots$ & $2 E-07$ & $1 E-07$ & - & $8 E+03$ & $6 \mathrm{E}+03$ & - & $\mathrm{BS} / \mathrm{St} /$ \\
\hline Hf-180m .................... & $2 E-06$ & $1 E-06$ & - & $7 E+04$ & $6 \mathrm{E}+04$ & - & $\mathrm{ET} / \mathrm{ET} /$ \\
\hline $\mathrm{Hf}-181 \ldots \ldots \ldots \ldots \ldots \ldots$ & $1 \mathrm{E}-07$ & $1 \mathrm{E}-07$ & - & $4 E+03$ & $5 E+03$ & - & $\mathrm{BS} / \mathrm{St} /$ \\
\hline Hf-182m .................. & $5 E-06$ & $4 E-06$ & - & $2 E+05$ & $1 E+05$ & - & $\mathrm{ET} / \mathrm{ET} /$ \\
\hline $\mathrm{Hf}-182 \ldots \ldots \ldots \ldots \ldots \ldots$ & $5 E-10$ & $2 E-09$ & - & $2 E+01$ & $9 \mathrm{E}+01$ & - & BS/BS/ \\
\hline $\mathrm{Hf}-183 \ldots \ldots \ldots \ldots \ldots$ & $6 \mathrm{E}-06$ & $4 \mathrm{E}-06$ & - & $2 E+05$ & $1 \mathrm{E}+05$ & - & $\mathrm{ET} / \mathrm{ET} /$ \\
\hline $\mathrm{Hf}-184 \ldots \ldots \ldots \ldots \ldots$ & $1 \mathrm{E}-06$ & $1 E-06$ & - & $5 E+04$ & $4 E+04$ & - & $\mathrm{ET} / \mathrm{St} /$ \\
\hline Тa-172 ....................... & - & $5 E-06$ & $5 E-06$ & - & $1 \mathrm{E}+05$ & $1 \mathrm{E}+05$ & $/ \mathrm{ET} / \mathrm{ET}$ \\
\hline Ta-173 ................... & - & $3 E-06$ & $3 E-06$ & - & $1 \mathrm{E}+05$ & $1 \mathrm{E}+05$ & $/ E / E$ \\
\hline Ta-174 .................... & - & $5 E-06$ & $5 E-06$ & - & $2 E+05$ & $2 \mathrm{E}+05$ & $/ E T / E T$ \\
\hline Тa-175 ……......... & - & $1 \mathrm{E}-06$ & $1 E-06$ & - & $6 \mathrm{E}+04$ & $6 \mathrm{E}+04$ & /ET/ET \\
\hline Ta-176 .................... & - & $1 \bar{E}-06$ & $1 \mathrm{E}-06$ & - & $3 E+04$ & $3 \mathrm{E}+04$ & /ET/ET \\
\hline Ta-177 …................ & - & $4 \bar{E}-06$ & $4 E-06$ & - & $1 \mathrm{E}+05$ & $1 \mathrm{E}+05$ & $/ \mathrm{St} / \mathrm{St}$ \\
\hline Ta-178 ……......... & - & $3 E-06$ & $3 E-06$ & - & $1 \mathrm{E}+05$ & $1 \mathrm{E}+05$ & /ET/ET \\
\hline Тa-179 …….......... & - & $4 E-06$ & $1 E-06$ & - & $1 \mathrm{E}+05$ & $7 \mathrm{E}+04$ & $/ \mathrm{St} / \mathrm{St}$ \\
\hline Ta-180m …............ & - & $9 \bar{E}-06$ & $9 E-06$ & - & $3 E+05$ & $3 E+05$ & $/ \mathrm{St} / \mathrm{St}$ \\
\hline Ta-180 ……........... & - & $1 \mathrm{E}-07$ & $4 E-08$ & - & $4 \mathrm{E}+03$ & $1 \mathrm{E}+03$ & $/ \mathrm{St} / \mathrm{St}$ \\
\hline Ta-182m …........... & - & $6 E-06$ & $6 E-06$ & - & $2 E+05$ & $2 \mathrm{E}+05$ & /ET/ET \\
\hline Ta-182 ..................... & - & $9 E-08$ & $7 E-08$ & - & $3 E+03$ & $2 \mathrm{E}+03$ & $/ \mathrm{St} / \mathrm{St}$ \\
\hline Ta-183 .................. & - & $3 E-07$ & $2 E-07$ & - & $1 E+04$ & $1 \mathrm{E}+04$ & $/ \mathrm{St} / \mathrm{St}$ \\
\hline Тa-184 ……........... & - & $8 E-07$ & $8 E-07$ & - & $3 E+04$ & $3 \mathrm{E}+04$ & /ET/ET \\
\hline Ta-185 ….............. & - & $5 E-06$ & $5 E-06$ & - & $2 E+05$ & $1 \mathrm{E}+05$ & $/ E T / E T$ \\
\hline Тa-186 …….......... & - & $7 E-06$ & $7 E-06$ & - & $2 E+05$ & $2 \mathrm{E}+05$ & /ET/ET \\
\hline W-176 …….............. & $3 E-06$ & - & - & $1 E+05$ & - & - & $\mathrm{ET} / /$ \\
\hline W-177 …............... & $5 E-06$ & - & - & $2 E+05$ & - & - & $\mathrm{ET} / /$ \\
\hline W-178 & $3 E-06$ & - & - & $1 \mathrm{E}+05$ & - & - & $\mathrm{ET} /$ / \\
\hline W-179 ……............ & $1 \mathrm{E}-04$ & - & - & $5 E+06$ & - & - & ET/ / \\
\hline W-181 … & $1 E-05$ & - & - & $4 E+05$ & - & - & $\mathrm{ET} / /$ \\
\hline W-185 …............... & $2 E-06$ & - & - & $9 \mathrm{E}+04$ & - & - & St/ / \\
\hline W-187 … & $1 E-06$ & - & - & $5 E+04$ & - & - & $\mathrm{ET} / /$ \\
\hline W-188 ……............. & $6 \mathrm{E}-07$ & - & - & $2 E+04$ & - & - & $\mathrm{St} / \mathrm{I}$ \\
\hline Re-177 ................... & $1 \mathrm{E}-05$ & $1 E-05$ & - & $6 \mathrm{E}+05$ & $4 \mathrm{E}+05$ & - & $\mathrm{ET} / \mathrm{ET} /$ \\
\hline Re-178 & $1 E-05$ & $1 E-05$ & - & $5 E+05$ & $3 E+05$ & - & $\mathrm{ET} / \mathrm{ET} /$ \\
\hline Re-181 .................. & $1 \mathrm{E}-06$ & $1 E-06$ & - & $5 E+04$ & $4 \mathrm{E}+04$ & - & $\mathrm{ET} / \mathrm{ET} /$ \\
\hline Re-182 (64 h) ..... & $4 \mathrm{E}-07$ & $3 E-07$ & - & $1 E+04$ & $1 E+04$ & - & $\mathrm{ET} / \mathrm{St} /$ \\
\hline Re-182 (12 h) ..... & $1 \mathrm{E}-06$ & $1 E-06$ & - & $4 E+04$ & $4 \mathrm{E}+04$ & - & $\mathrm{ET} / \mathrm{ET} /$ \\
\hline Re-184m ................. & $6 \mathrm{E}-07$ & $1 E-07$ & - & $2 E+04$ & $4 E+03$ & - & $\mathrm{St} / \mathrm{St} /$ \\
\hline Re-184 ................... & $7 E-07$ & $3 E-07$ & - & $2 E+04$ & $1 \mathrm{E}+04$ & - & $E T / S t /$ \\
\hline Re-186m ................ & $4 \bar{E}-7$ & $7 \bar{E}-08$ & - & $1 \mathrm{E}+04$ & $2 E+03$ & - & $\mathrm{St} / \mathrm{St} /$ \\
\hline Re-186 .................. & $7 E-07$ & $4 E-07$ & - & $2 E+04$ & $1 E+04$ & - & $\mathrm{St} / \mathrm{St} /$ \\
\hline Re-187 ................... & $2 E-04$ & $1 \mathrm{E}-04$ & - & $8 E+06$ & $4 \mathrm{E}+06$ & - & $\mathrm{St} / \mathrm{St} /$ \\
\hline Re-188m .................. & $3 E-05$ & $2 E-05$ & - & $1 E+06$ & $1 \mathrm{E}+06$ & - & $\mathrm{St} / \mathrm{St} /$ \\
\hline $\operatorname{Re}-188 \ldots \ldots \ldots \ldots \ldots$ & $8 \mathrm{E}-07$ & $7 E-07$ & - & $3 E+04$ & $2 E+04$ & - & $\mathrm{St} / \mathrm{St} /$ \\
\hline Re-189 .................. & $1 \mathrm{E}-06$ & $9 E-07$ & - & $4 \mathrm{E}+04$ & $3 E+04$ & - & $\mathrm{St} / \mathrm{St} /$ \\
\hline Os-180 ..................... & $1 \mathrm{E}-05$ & $1 E-05$ & $1 E-05$ & $5 E+05$ & $3 E+05$ & $3 E+05$ & ET/ET/ET \\
\hline Os-181 ...................... & $3 E-06$ & $3 E-06$ & $3 E-06$ & $1 E+05$ & $1 \mathrm{E}+05$ & $1 \mathrm{E}+05$ & $\mathrm{ET} / \mathrm{ET} / \mathrm{ET}$ \\
\hline Os-182 …................ & $1 \bar{E}-06$ & $9 \bar{E}-07$ & $9 \bar{E}-07$ & $3 E+04$ & $3 E+04$ & $3 \mathrm{E}+04$ & ET/ET/ET \\
\hline Os-185 ..................... & $4 \mathrm{E}-07$ & $5 E-07$ & $5 E-07$ & $1 E+04$ & $2 E+04$ & $1 \mathrm{E}+04$ & $\mathrm{St} / \mathrm{St} / \mathrm{St}$ \\
\hline Os-189m …............... & $1 E-04$ & $7 E-05$ & $7 E-05$ & $4 E+06$ & $2 E+06$ & $2 \mathrm{E}+06$ & $\mathrm{St} / \mathrm{St} / \mathrm{St}$ \\
\hline Os-191m ................... & $1 \mathrm{E}-05$ & $4 E-06$ & $4 E-06$ & $5 E+05$ & $1 E+05$ & $1 \mathrm{E}+05$ & $\mathrm{St} / \mathrm{St} / \mathrm{St}$ \\
\hline Os-191 ...................... & $1 \mathrm{E}-06$ & $4 \mathrm{E}-07$ & $3 E-07$ & $5 E+04$ & $1 \mathrm{E}+04$ & $1 \mathrm{E}+04$ & $\mathrm{St} / \mathrm{St} / \mathrm{St}$ \\
\hline Os-193 …............... & $2 \bar{E}-06$ & $8 \bar{E}-07$ & $8 \bar{E}-07$ & $7 E+04$ & $3 E+04$ & $3 \mathrm{E}+04$ & $\mathrm{St} / \mathrm{St} / \mathrm{St}$ \\
\hline Os-194 …........... & $4 E-08$ & $4 E-08$ & $1 E-08$ & $1 \mathrm{E}+03$ & $1 \mathrm{E}+03$ & $4 \mathrm{E}+02$ & $\mathrm{St} / \mathrm{St} / \mathrm{St}$ \\
\hline $\mid \mathrm{r}-182 \quad \ldots \ldots \ldots \ldots \ldots \ldots$ & $9 E-06$ & $7 E-06$ & $7 E-06$ & $3 E+05$ & $2 E+05$ & $2 \mathrm{E}+05$ & ET/ET/ET \\
\hline $\mid \mathrm{r}-184 \ldots \ldots \ldots \ldots \ldots \ldots$ & $1 \mathrm{E}-06$ & $1 \mathrm{E}-06$ & $1 \mathrm{E}-06$ & $7 E+04$ & $6 \mathrm{E}+04$ & $7 \mathrm{E}+04$ & ET/ET/ET \\
\hline $\mid \mathrm{r}-185$ & $2 E-06$ & $1 E-06$ & $1 E-06$ & $7 E+04$ & $7 E+04$ & $7 \mathrm{E}+04$ & ET/ET/ET \\
\hline $\mid \mathrm{r}-186(16 \mathrm{~h}) \ldots \ldots$ & $8 \mathrm{E}-07$ & $7 \mathrm{E}-07$ & $7 E-07$ & $2 E+04$ & $2 E+04$ & $2 \mathrm{E}+04$ & ET/ET/ET \\
\hline $\mid r-186(2$ h) .............. & $5 E-06$ & $4 \mathrm{E}-06$ & $4 E-06$ & $1 \mathrm{E}+05$ & $1 \mathrm{E}+05$ & $1 \mathrm{E}+05$ & ET/ET/ET \\
\hline $\mid \mathrm{r}-187 \ldots$ & $4 E-06$ & $3 E-06$ & $3 E-06$ & $1 E+05$ & $1 \mathrm{E}+05$ & $1 \mathrm{E}+05$ & ET/ET/ET \\
\hline |r-188 & $6 E-07$ & $6 E-07$ & $6 E-07$ & $2 E+04$ & $2 E+04$ & $2 \mathrm{E}+04$ & ET/ET/ET \\
\hline $\mid \mathrm{r}-189$ & $3 E-06$ & $1 \mathrm{E}-06$ & $1 E-06$ & $1 E+05$ & $5 E+04$ & $4 \mathrm{E}+04$ & $\mathrm{St} / \mathrm{St} / \mathrm{St}$ \\
\hline Ir-190m (3 h) ....... & $2 E-06$ & $2 E-06$ & $2 E-06$ & $8 E+04$ & $8 E+04$ & $7 \mathrm{E}+04$ & ET/ET/ET \\
\hline Ir-190m (1 h) ........ & $9 E-05$ & $5 E-05$ & $5 E-05$ & $3 E+06$ & $2 E+06$ & $1 \mathrm{E}+06$ & $\mathrm{ET} / \mathrm{St} / \mathrm{St}$ \\
\hline
\end{tabular}


Department of Energy

Pt. 835, App. A

\begin{tabular}{|c|c|c|c|c|c|c|c|}
\hline \multirow{3}{*}{ Radionuclide } & \multicolumn{3}{|c|}{ Absorption type ${ }^{3}$} & \multicolumn{3}{|c|}{ Absorption type ${ }^{3}$} & \multirow{2}{*}{$\begin{array}{c}\text { Stochastic or } \\
\text { organ or tis- } \\
\text { sue }^{1}\end{array}$} \\
\hline & \multicolumn{3}{|c|}{$\mu \mathrm{Ci} / \mathrm{mL}$} & \multicolumn{3}{|c|}{$\mathrm{Bq} / \mathrm{m}^{3}$} & \\
\hline & $\mathrm{F}$ & M & $S$ & $\mathrm{~F}$ & M & $\mathrm{S}$ & $(\mathrm{F} / \mathrm{M} / \mathrm{S})$ \\
\hline $\mid r-190$ & $4 E-07$ & $2 E-07$ & $2 E-07$ & $1 E+04$ & $9 \mathrm{E}+03$ & $8 \mathrm{E}+03$ & $\mathrm{ET} / \mathrm{St} / \mathrm{St}$ \\
\hline $\mid \mathrm{r}-192 \mathrm{~m}$ & $1 \mathrm{E}-07$ & $1 \mathrm{E}-07$ & $2 E-08$ & $3 \mathrm{E}+03$ & $6 \mathrm{E}+03$ & $1 E+03$ & $\mathrm{St} / \mathrm{St} / \mathrm{St}$ \\
\hline $\mid \mathrm{r}-192 \ldots \ldots \ldots \ldots \ldots$ & $2 E-07$ & $1 \mathrm{E}-07$ & $1 E-07$ & $9 \mathrm{E}+03$ & $5 E+03$ & $4 \mathrm{E}+03$ & $\mathrm{St} / \mathrm{St} / \mathrm{St}$ \\
\hline $\mid \mathrm{r}-194 \mathrm{~m}$ & $8 E-08$ & $8 \bar{E}-08$ & $6 \mathrm{E}-08$ & $3 E+03$ & $3 E+03$ & $2 \mathrm{E}+03$ & $\mathrm{St} / \mathrm{St} / \mathrm{St}$ \\
\hline Ir-194 ….................. & $1 \mathrm{E}-06$ & $7 \mathrm{E}-07$ & $7 E-07$ & $5 \mathrm{E}+04$ & $2 E+04$ & $2 \mathrm{E}+04$ & $\mathrm{St} / \mathrm{St} / \mathrm{St}$ \\
\hline $\mid \mathrm{r}-195 \mathrm{~m}$ & $2 E-06$ & $2 E-06$ & $2 E-06$ & $9 \mathrm{E}+04$ & $7 E+04$ & $7 \mathrm{E}+04$ & $\mathrm{ET} / \mathrm{ET} / \mathrm{ET}$ \\
\hline $\mid \mathrm{r}-195$ & $7 E-06$ & $5 E-06$ & $4 E-06$ & $2 E+05$ & $1 E+05$ & $1 E+05$ & $\mathrm{ET} / \mathrm{ET} / \mathrm{ET}$ \\
\hline Pt-186 …….............. & $3 E-06$ & - & - & $1 \mathrm{E}+05$ & - & - & $\mathrm{ET} / / /$ \\
\hline Pt-188 …….............. & $8 \mathrm{E}-07$ & - & - & $3 E+04$ & - & - & E/ / \\
\hline Pt-189 ……............ & $3 E-06$ & - & - & $1 \mathrm{E}+05$ & - & - & $\mathrm{ET} / /$ \\
\hline Pt-191 ……........... & $1 \mathrm{E}-06$ & - & - & $7 E+04$ & - & - & ET/ / \\
\hline Pt-193m ……........... & $2 E-06$ & - & - & $8 \mathrm{E}+04$ & - & - & $\mathrm{ET} / /$ \\
\hline Pt-193 ……............. & $2 E-05$ & - & - & $7 E+05$ & - & - & $\mathrm{ET} /$ / \\
\hline Pt-195m ................. & $1 \mathrm{E}-06$ & - & - & $5 E+04$ & - & - & $\mathrm{ET} /$ / \\
\hline Pt-197m ….............. & $7 E-06$ & - & - & $2 E+05$ & - & - & $\mathrm{ET} / /$ \\
\hline Pt-197 ……............. & $3 E-06$ & - & - & $1 \mathrm{E}+05$ & - & - & $\mathrm{ET} / /$ \\
\hline Pt-199 …….......... & $1 \mathrm{E}-05$ & - & - & $4 \mathrm{E}+05$ & - & - & $\mathrm{ET} /$ / \\
\hline Pt-200 ……........... & $1 \mathrm{E}-06$ & - & - & $5 E+04$ & - & - & St/ / \\
\hline Au-193 ................... & $4 \mathrm{E}-06$ & $3 E-06$ & $3 E-06$ & $1 \mathrm{E}+05$ & $1 E+05$ & $1 E+05$ & $\mathrm{ET} / \mathrm{E} / \mathrm{St}$ \\
\hline Au-194 ................... & $9 \mathrm{E}-07$ & $9 \bar{E}-07$ & $9 \mathrm{E}-07$ & $3 E+04$ & $3 E+04$ & $3 E+04$ & $\mathrm{ET} / \mathrm{ET} / \mathrm{ET}$ \\
\hline Au-195 .................. & $3 E-06$ & $7 E-07$ & $4 \mathrm{E}-07$ & $1 \mathrm{E}+05$ & $2 E+04$ & $1 \mathrm{E}+04$ & $\mathrm{ET} / \mathrm{St} / \mathrm{St}$ \\
\hline Au-198m ................ & $6 \mathrm{E}-07$ & $2 \mathrm{E}-07$ & $2 E-07$ & $2 \mathrm{E}+04$ & $1 E+04$ & $1 \mathrm{E}+04$ & $\mathrm{ET} / \mathrm{St} / \mathrm{St}$ \\
\hline Au-198 & $1 \mathrm{E}-06$ & $5 E-07$ & $5 E-07$ & $4 \mathrm{E}+04$ & $2 E+04$ & $1 E+04$ & $\mathrm{ET} / \mathrm{St} / \mathrm{St}$ \\
\hline Au-199 & $2 E-06$ & $8 \bar{E}-07$ & $7 E-07$ & $7 \mathrm{E}+04$ & $3 E+04$ & $2 \mathrm{E}+04$ & $\mathrm{ET} / \mathrm{St} / \mathrm{St}$ \\
\hline 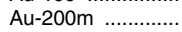 & $5 E-07$ & $4 E-07$ & $4 E-07$ & $1 \mathrm{E}+04$ & $1 E+04$ & $1 \mathrm{E}+04$ & $\mathrm{ET} / \mathrm{ET} / \mathrm{ET}$ \\
\hline Au-200 ................... & $1 E-05$ & $7 E-06$ & $7 E-06$ & $4 \mathrm{E}+05$ & $2 E+05$ & $2 \mathrm{E}+05$ & $\mathrm{ET} / \mathrm{ET} / \mathrm{ET}$ \\
\hline $\mathrm{Au}-201$ & $1 \bar{E}-05$ & $1 \bar{E}-05$ & $9 E-06$ & $5 E+05$ & $3 E+05$ & $3 \mathrm{E}+05$ & ET/ET/ET \\
\hline Hg-193m (Org) ... & $1 \mathrm{E}-06$ & - & - & $4 \mathrm{E}+04$ & - & - & $\mathrm{ET} / /$ \\
\hline $\mathrm{Hg}-193 \mathrm{~m} \ldots \ldots \ldots \ldots$. & $1 \mathrm{E}-06$ & $1 \mathrm{E}-06$ & - & $4 \mathrm{E}+04$ & $4 E+04$ & - & $\mathrm{ET} / \mathrm{ET} /$ \\
\hline Hg-193m (Vapor) & - & $1 E-07$ & - & - & $6 \mathrm{E}+03$ & - & /St/ \\
\hline Hg-193 (Org) ....... & $5 E-06$ & - & - & $1 \mathrm{E}+05$ & - & - & $\mathrm{ET} / /$ \\
\hline $\mathrm{Hg}-193 \ldots \ldots \ldots \ldots . . .$. & $5 E-06$ & $4 \mathrm{E}-06$ & - & $1 \mathrm{E}+05$ & $1 E+05$ & - & $\mathrm{ET} / \mathrm{ET} /$ \\
\hline Hg-193 (Vapor) ... & - & $5 E-07$ & - & - & $1 E+04$ & - & $/ \mathrm{St} /$ \\
\hline Hg-194 (Org) ....... & $2 E-08$ & - & - & $1 \mathrm{E}+03$ & - & - & $\mathrm{St} / 1$ \\
\hline Hg-194 ................... & $3 E-08$ & $1 \mathrm{E}-07$ & - & $1 \mathrm{E}+03$ & $3 E+03$ & - & $\mathrm{St} / \mathrm{St} /$ \\
\hline Hg-194 (Vapor) ... & - & $1 E-08$ & - & - & $5 E+02$ & - & $/ \mathrm{St} /$ \\
\hline $\mathrm{Hg}-195 \mathrm{~m}(\mathrm{Org}) \ldots$ & $1 E-06$ & - & - & $5 \mathrm{E}+04$ & - & - & $\mathrm{ET} / /$ \\
\hline $\mathrm{Hg}-195 \mathrm{~m} \ldots \ldots \ldots \ldots$ & $1 \mathrm{E}-06$ & $8 E-07$ & - & $5 E+04$ & $3 E+04$ & - & $\mathrm{ET} / \mathrm{St} /$ \\
\hline Hg-195m (Vapor) & - & $6 E-08$ & - & - & $2 E+03$ & - & $/ \mathrm{St} /$ \\
\hline $\mathrm{Hg}-195$ (Org) ....... & $6 \mathrm{E}-06$ & - & - & $2 \mathrm{E}+05$ & - & - & $\mathrm{ET} / /$ \\
\hline 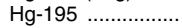 & $6 \mathrm{E}-06$ & $6 \mathrm{E}-06$ & - & $2 E+05$ & $2 E+05$ & - & $\mathrm{ET} / \mathrm{ET} /$ \\
\hline Hg-195 (Vapor) ... & - & $4 \mathrm{E}-07$ & - & - & $1 E+04$ & - & $/ \mathrm{St} /$ \\
\hline $\mathrm{Hg}-197 \mathrm{~m}(\mathrm{Org}) \ldots$ & $1 E-06$ & - & - & $5 \mathrm{E}+04$ & - & - & $\mathrm{ET} / /$ \\
\hline $\mathrm{Hg}-197 \mathrm{~m}$ & $1 \mathrm{E}-06$ & $8 E-07$ & - & $5 \mathrm{E}+04$ & $3 E+04$ & - & $\mathrm{ET} / \mathrm{St} /$ \\
\hline Hg-197m (Vapor) & - & $9 \mathrm{E}-08$ & - & - & $3 \mathrm{E}+03$ & - & $/ \mathrm{St} /$ \\
\hline $\mathrm{Hg}-197$ (Org) ...... & $4 \mathrm{E}-06$ & - & - & $1 \mathrm{E}+05$ & - & - & $\mathrm{ET} / /$ \\
\hline $\mathrm{Hg}-197 \ldots \ldots \ldots$ & $4 \bar{E}-06$ & $2 E-06$ & - & $1 \mathrm{E}+05$ & $7 E+04$ & - & $\mathrm{ET} / \mathrm{St} /$ \\
\hline Hg-197 (Vapor) ... & - & $1 \mathrm{E}-07$ & - & - & $4 \mathrm{E}+03$ & - & $/ \mathrm{St} /$ \\
\hline $\mathrm{Hg}-199 \mathrm{~m}$ (Org) ... & $8 \mathrm{E}-06$ & - & - & $3 E+05$ & - & - & $\mathrm{ET} / /$ \\
\hline $\mathrm{Hg}-199 \mathrm{~m}$ & $8 \mathrm{E}-06$ & $5 E-06$ & - & $3 E+05$ & $1 E+05$ & - & ET/ET/ \\
\hline Hg-199m (Vapor) & - & $3 E-06$ & - & - & $1 E+05$ & - & $/ \mathrm{St} /$ \\
\hline Hg-203 (Org) ...... & $7 E-07$ & - & - & $2 \mathrm{E}+04$ & - & - & $\mathrm{St} / \mathrm{I}$ \\
\hline $\mathrm{Hg}-203$................. & $9 \mathrm{E}-07$ & $2 E-07$ & - & $3 E+04$ & $1 E+04$ & - & $\mathrm{St} / \mathrm{St} /$ \\
\hline Hg-203 (Vapor) ... & - & $8 E-08$ & - & - & $2 E+03$ & - & $/ \mathrm{St} /$ \\
\hline Tl-194m …................. & $5 \mathrm{E}-06$ & - & - & $2 \mathrm{E}+05$ & - & - & ET/ / \\
\hline Tl-194 ................... & $2 E-05$ & - & - & $8 E+05$ & - & - & $\mathrm{ET} /$ / \\
\hline TI-195 ………........ & $6 \mathrm{E}-06$ & - & - & $2 E+05$ & - & - & $\mathrm{ET} / /$ \\
\hline TI-197 …….............. & $8 \mathrm{E}-06$ & - & - & $2 E+05$ & - & - & ET/ / \\
\hline Tl-198m ……........... & $2 E-06$ & - & - & $9 \mathrm{E}+04$ & - & - & $\mathrm{ET} / /$ \\
\hline Tl-198 ……............ & $1 \mathrm{E}-06$ & - & - & $5 \mathrm{E}+04$ & - & - & ET/ / \\
\hline TI-199 .......... & $5 E-06$ & - & - & $2 \mathrm{E}+05$ & - & - & $\mathrm{ET} / /$ \\
\hline TI-200 ......... & $8 \mathrm{E}-07$ & - & - & $3 E+04$ & - & - & $\mathrm{ET} / /$ \\
\hline TI-201 ...................... & $4 \mathrm{E}-06$ & - & - & $1 \mathrm{E}+05$ & - & - & $\mathrm{ET} / /$ \\
\hline TI-202 ....... & $1 E-06$ & - & - & $5 E+04$ & - & - & $\mathrm{ET} / /$ \\
\hline Tl-204 .............. & $9 \mathrm{E}-07$ & - & - & $3 E+04$ & - & - & St/ / \\
\hline Pb-195m ….............. & $7 E-06$ & - & - & $2 \mathrm{E}+05$ & - & - & $\mathrm{ET} / /$ \\
\hline $\mathrm{Pb}-198$ & $2 E-06$ & - & - & $9 \mathrm{E}+04$ & - & - & $\mathrm{ET} / /$ \\
\hline Pb-199 …….............. & $4 \mathrm{E}-06$ & - & - & $1 \mathrm{E}+05$ & - & - & $\mathrm{ET} / /$ \\
\hline $\mathrm{Pb}-200$ & $1 \mathrm{E}-06$ & - & - & $4 \mathrm{E}+04$ & - & - & $\mathrm{ET} / /$ \\
\hline $\mathrm{Pb}-201 \ldots \ldots \ldots \ldots \ldots$ & $2 E-06$ & - & - & $7 \mathrm{E}+04$ & - & - & $\mathrm{ET} / /$ \\
\hline $\mathrm{Pb}-202 \mathrm{~m}$ & $1 \mathrm{E}-06$ & - & - & $6 \mathrm{E}+04$ & - & - & $\mathrm{ET} / /$ \\
\hline
\end{tabular}


Pt. 835, App. A

10 CFR Ch. III (1-1-08 Edition)

\begin{tabular}{|c|c|c|c|c|c|c|c|}
\hline \multirow{3}{*}{ Radionuclide } & \multicolumn{3}{|c|}{ Absorption type ${ }^{3}$} & \multicolumn{3}{|c|}{ Absorption type ${ }^{3}$} & \multirow{2}{*}{$\begin{array}{l}\text { Stochastic or } \\
\text { organ or tis- } \\
\text { sue } 1\end{array}$} \\
\hline & \multicolumn{3}{|c|}{$\mu \mathrm{Ci} / \mathrm{mL}$} & \multicolumn{3}{|c|}{$\mathrm{Bq} / \mathrm{m}^{3}$} & \\
\hline & $\mathrm{F}$ & M & $S$ & $\mathrm{~F}$ & M & $S$ & $(\mathrm{~F} / \mathrm{M} / \mathrm{S})$ \\
\hline Pb-202 ….................. & $4 \mathrm{E}-08$ & - & - & $1 \mathrm{E}+03$ & - & - & St/ / \\
\hline Pb-203 …................. & $2 E-06$ & - & - & $7 \mathrm{E}+04$ & - & - & $\mathrm{ET} / / /$ \\
\hline Pb-205 ….................. & $9 \mathrm{E}-07$ & - & - & $3 E+04$ & - & - & $\mathrm{BS} / \mathrm{I}$ \\
\hline Pb-209 ….................. & $9 \mathrm{E}-06$ & - & - & $3 E+05$ & - & - & $\mathrm{ET} / /$ \\
\hline Pb-210 ....................... & $1 \mathrm{E}-10$ & - & - & $5 E+00$ & - & - & $\mathrm{BS} / \mathrm{I}$ \\
\hline $\mathrm{Pb}-211 \ldots \ldots \ldots \ldots \ldots$ & $4 E-08$ & - & - & $1 \mathrm{E}+03$ & - & - & $\mathrm{ET} / /$ \\
\hline $\mathrm{Pb}-212 \ldots \ldots \ldots \ldots \ldots$ & $5 E-09$ & - & - & $2 E+02$ & - & - & $\mathrm{ET} / /$ \\
\hline Pb-214 …................. & $4 E-08$ & - & - & $1 E+03$ & - & - & $\mathrm{ET} / /$ \\
\hline Вi-200 ……............ & $5 E-06$ & $4 E-06$ & - & $2 E+05$ & $1 \mathrm{E}+05$ & - & $\mathrm{ET} / \mathrm{ET} /$ \\
\hline Bi-201 …................ & $3 E-06$ & $2 E-06$ & - & $1 E+05$ & $1 \mathrm{E}+05$ & - & $\mathrm{ET} / \mathrm{ET} /$ \\
\hline Bi-202 ….................. & $2 E-06$ & $2 E-06$ & - & $9 E+04$ & $9 \mathrm{E}+04$ & - & $\mathrm{ET} / \mathrm{ET} /$ \\
\hline Bi-203 …................. & $7 E-07$ & $7 E-07$ & - & $2 E+04$ & $2 \mathrm{E}+04$ & - & $\mathrm{ET} / \mathrm{ET} /$ \\
\hline Bi-205 …................ & $4 \mathrm{E}-07$ & $4 \mathrm{E}-07$ & - & $1 E+04$ & $1 \mathrm{E}+04$ & - & $\mathrm{ET} / \mathrm{ET} /$ \\
\hline Bi-206 ...................... & $2 E-07$ & $2 E-07$ & - & $9 \mathrm{E}+03$ & $8 \mathrm{E}+03$ & - & $\mathrm{ET} / \mathrm{ET} /$ \\
\hline Bi-207 …................. & $4 \mathrm{E}-07$ & $1 \mathrm{E}-07$ & - & $1 \mathrm{E}+04$ & $6 \mathrm{E}+03$ & - & $\mathrm{ET} / \mathrm{St} /$ \\
\hline Bi-210m ...................... & $3 E-09$ & $2 E-10$ & - & $1 \mathrm{E}+02$ & $9 \mathrm{E}+00$ & - & $\mathrm{K} / \mathrm{St} /$ \\
\hline Bi-210 ................. & $1 E-07$ & $9 E-09$ & - & $6 \mathrm{E}+03$ & $3 \mathrm{E}+02$ & - & $\mathrm{K} / \mathrm{St} /$ \\
\hline Bi-212 …................. & $1 E-08$ & $8 E-09$ & - & $4 \mathrm{E}+02$ & $3 \mathrm{E}+02$ & - & $\mathrm{ET} / \mathrm{ET} /$ \\
\hline Вi-213 …................ & $1 E-08$ & $7 E-09$ & - & $4 E+02$ & $2 \mathrm{E}+02$ & - & $\mathrm{ET} / \mathrm{ET} /$ \\
\hline $\mathrm{Bi}-214 \ldots \ldots \ldots \ldots \ldots \ldots$ & $1 \bar{E}-08$ & $1 \bar{E}-08$ & - & $6 \mathrm{E}+02$ & $4 \mathrm{E}+02$ & - & $\mathrm{ET} / \mathrm{ET} /$ \\
\hline Po-203 .................... & $5 E-06$ & $4 E-06$ & - & $1 E+05$ & $1 \mathrm{E}+05$ & - & $\mathrm{ET} / \mathrm{ET} /$ \\
\hline Po-205 ……............. & $4 \mathrm{E}-06$ & $3 E-06$ & - & $1 \mathrm{E}+05$ & $1 \mathrm{E}+05$ & - & $\mathrm{ET} / \mathrm{ET} /$ \\
\hline Po-207 …................. & $1 E-06$ & $1 \mathrm{E}-06$ & - & $7 E+04$ & $6 \mathrm{E}+04$ & - & $\mathrm{ET} / \mathrm{ET} /$ \\
\hline Po-210 …….............. & $7 E-10$ & $2 E-10$ & - & $2 \mathrm{E}+01$ & $9 \mathrm{E}+00$ & - & $\mathrm{K} / \mathrm{St} /$ \\
\hline At-207 …............... & $1 E-06$ & $2 E-07$ & - & $4 \mathrm{E}+04$ & $1 \mathrm{E}+04$ & - & $\mathrm{St} / \mathrm{St} /$ \\
\hline At-211 …….......... & $7 E-09$ & $5 E-09$ & - & $2 E+02$ & $1 \mathrm{E}+02$ & - & $\mathrm{ET} / \mathrm{St} /$ \\
\hline Rn-220 5 ................. & $1 E-08$ & - & - & $6 \mathrm{E}+02$ & - & - & - \\
\hline Rn-222 5 ................. & $8 E-08$ & - & - & $3 E+03$ & - & - & - \\
\hline Fr-222 ……............ & $1 E-08$ & - & - & $3 E+02$ & - & - & $\mathrm{ET} / /$ \\
\hline Fr-223 ……............ & $4 \mathrm{E}-07$ & - & - & $1 \mathrm{E}+04$ & - & - & St/ / \\
\hline Ra-223 ................... & - & $9 E-11$ & - & - & $3 \mathrm{E}+00$ & - & $/ \mathrm{St} /$ \\
\hline Ra-224 .................. & - & $2 E-10$ & - & - & $8 \mathrm{E}+00$ & - & /St/ \\
\hline Ra-225 …............... & - & $1 E-10$ & - & - & $4 \mathrm{E}+00$ & - & $/ \mathrm{St} /$ \\
\hline Ra-226 .................... & - & $2 E-10$ & - & - & $9 \mathrm{E}+00$ & - & $/ \mathrm{St} /$ \\
\hline Ra-227 ................... & - & $8 E-07$ & - & - & $3 \mathrm{E}+04$ & - & /BS/ \\
\hline Ra-228 .................. & - & $1 \mathrm{E}-10$ & - & - & $5 \mathrm{E}+00$ & - & /BS/ \\
\hline Ac-224 ................... & $1 E-08$ & $6 E-09$ & $5 E-09$ & $6 \mathrm{E}+02$ & $2 \mathrm{E}+02$ & $2 \mathrm{E}+02$ & $\mathrm{BS} / \mathrm{St} / \mathrm{St}$ \\
\hline Ac-225 ……......... & $2 E-10$ & $9 \mathrm{E}-11$ & $8 E-11$ & $7 \mathrm{E}+00$ & $3 \mathrm{E}+00$ & $3 \mathrm{E}+00$ & $\mathrm{BS} / \mathrm{St} / \mathrm{St}$ \\
\hline Ac-226 ................... & $1 E-09$ & $6 E-10$ & $5 E-10$ & $4 \mathrm{E}+01$ & $2 \mathrm{E}+01$ & $2 E+01$ & $E T / S t / S t$ \\
\hline Ac-227 & $2 E-13$ & $1 E-12$ & $1 E-11$ & $1 E-02$ & $5 E-02$ & $4 \mathrm{E}-01$ & BS/BS/St \\
\hline Ac-228 ……......... & $6 \mathrm{E}-09$ & $3 E-08$ & $4 E-08$ & $2 \mathrm{E}+02$ & $1 \mathrm{E}+03$ & $1 \mathrm{E}+03$ & $\mathrm{BS} / \mathrm{BS} / \mathrm{St}$ \\
\hline Th-226 …….......... & - & $4 E-09$ & $4 E-09$ & - & $1 \mathrm{E}+02$ & $1 \mathrm{E}+02$ & /ET/ET \\
\hline Th-227 ……........... & - & $9 E-11$ & $7 E-11$ & - & $3 \mathrm{E}+00$ & $2 \mathrm{E}+00$ & $/ \mathrm{St} / \mathrm{St}$ \\
\hline Th-228 …….......... & - & $2 E-11$ & $2 E-11$ & - & $7 E-01$ & $8 E-01$ & /BS/St \\
\hline Th-229 …….......... & - & $2 E-12$ & $1 \mathrm{E}-11$ & - & $7 E-02$ & $4 \mathrm{E}-01$ & /BS/St \\
\hline Th-230 …….......... & - & $3 E-12$ & $4 E-11$ & - & $1 \mathrm{E}-01$ & $1 \mathrm{E}+00$ & /BS/BS \\
\hline Th-231 …….......... & - & $1 E-06$ & $1 E-06$ & - & $5 \mathrm{E}+04$ & $5 \mathrm{E}+04$ & $/ \mathrm{St} / \mathrm{St}$ \\
\hline Th-232 …............. & - & $3 E-12$ & $4 E-11$ & - & $1 \mathrm{E}-01$ & $1 \mathrm{E}+00$ & /BS/BS \\
\hline Th-234 …….......... & - & $1 \mathrm{E}-07$ & $9 E-08$ & - & $3 \mathrm{E}+03$ & $3 E+03$ & $/ \mathrm{St} / \mathrm{St}$ \\
\hline Pa-227 ……........... & - & $4 E-09$ & $4 E-09$ & - & $1 \mathrm{E}+02$ & $1 \mathrm{E}+02$ & $/ \mathrm{ET} / \mathrm{ET}$ \\
\hline Pa-228 ................... & - & $1 E-08$ & $1 E-08$ & - & $3 \mathrm{E}+02$ & $4 \mathrm{E}+02$ & /BS/St \\
\hline $\mathrm{Pa}-230 \ldots \ldots \ldots \ldots \ldots$ & - & $1 E-09$ & $9 E-10$ & - & $4 \mathrm{E}+01$ & $3 \mathrm{E}+01$ & $/ \mathrm{St} / \mathrm{St}$ \\
\hline Pa-231 ……......... & - & $1 \mathrm{E}-12$ & $1 \mathrm{E}-11$ & - & $4 E-02$ & $4 \mathrm{E}-01$ & /BS/BS \\
\hline $\mathrm{Pa}-232$................ & - & $1 E-08$ & $1 \mathrm{E}-07$ & - & $6 \mathrm{E}+02$ & $7 \mathrm{E}+03$ & /BS/BS \\
\hline Pa-233 …............... & - & $2 E-07$ & $1 \mathrm{E}-07$ & - & $7 \mathrm{E}+03$ & $6 \mathrm{E}+03$ & $/ \mathrm{St} / \mathrm{St}$ \\
\hline Pa-234 ...…….......... & - & $7 E-07$ & $7 E-07$ & - & $2 E+04$ & $2 \mathrm{E}+04$ & $/ \mathrm{ET} / \mathrm{ET}$ \\
\hline U-230 …….............. & $6 E-10$ & $5 E-11$ & $4 E-11$ & $2 E+01$ & $2 \mathrm{E}+00$ & $1 \mathrm{E}+00$ & $\mathrm{~K} / \mathrm{St} / \mathrm{St}$ \\
\hline U-231 ……............. & $2 E-06$ & $1 E-06$ & $1 E-06$ & $8 \mathrm{E}+04$ & $4 \mathrm{E}+04$ & $4 \mathrm{E}+04$ & $\mathrm{ET} / \mathrm{St} / \mathrm{St}$ \\
\hline U-232 …….............. & $5 E-11$ & $1 E-10$ & $2 E-11$ & $2 \mathrm{E}+00$ & $4 \mathrm{E}+00$ & $7 E-01$ & $\mathrm{BS} / \mathrm{St} / \mathrm{ET}$ \\
\hline U-233 ................ & $4 E-10$ & $2 E-10$ & $7 E-11$ & $1 \mathrm{E}+01$ & $9 \mathrm{E}+00$ & $2 \mathrm{E}+00$ & BS/St/ET \\
\hline U-234 ...................... & $5 E-10$ & $2 E-10$ & $7 E-11$ & $1 E+01$ & $9 \mathrm{E}+00$ & $2 \mathrm{E}+00$ & $\mathrm{BS} / \mathrm{St} / \mathrm{ET}$ \\
\hline U-235 ……............. & $5 E-10$ & $3 E-10$ & $8 E-11$ & $1 \mathrm{E}+01$ & $1 \mathrm{E}+01$ & $3 \mathrm{E}+00$ & $\mathrm{BS} / \mathrm{St} / \mathrm{ET}$ \\
\hline U-236 ...................... & $5 E-10$ & $2 E-10$ & $7 E-11$ & $1 \mathrm{E}+01$ & $1 \mathrm{E}+01$ & $2 \mathrm{E}+00$ & $\mathrm{BS} / \mathrm{St} / \mathrm{ET}$ \\
\hline U-237 …….............. & $1 E-06$ & $3 E-07$ & $3 E-07$ & $4 E+04$ & $1 \mathrm{E}+04$ & $1 \mathrm{E}+04$ & $\mathrm{ET} / \mathrm{St} / \mathrm{St}$ \\
\hline U-238 ……............. & $5 E-10$ & $3 E-10$ & $8 E-11$ & $2 E+01$ & $1 \mathrm{E}+01$ & $3 \mathrm{E}+00$ & $\mathrm{BS} / \mathrm{St} / \mathrm{ET}$ \\
\hline U-239 …….............. & $1 E-05$ & $9 \mathrm{E}-06$ & $9 E-06$ & $5 E+05$ & $3 \mathrm{E}+05$ & $3 \mathrm{E}+05$ & ET/ET/ET \\
\hline U-240 …................. & $1 E-06$ & $7 E-07$ & $6 \mathrm{E}-07$ & $5 E+04$ & $2 E+04$ & $2 \mathrm{E}+04$ & $\mathrm{ET} / \mathrm{St} / \mathrm{St}$ \\
\hline Np-232 ..................... & - & $3 E-06$ & - & - & $1 \mathrm{E}+05$ & - & /BS/ \\
\hline Np-233 ................... & - & $7 E-05$ & - & - & $2 \mathrm{E}+06$ & - & /ET/ \\
\hline Np-234 ................ & - & $5 E-07$ & - & - & $2 \mathrm{E}+04$ & - & $/ E T /$ \\
\hline Np-235 …................ & - & $1 E-06$ & - & - & $4 \mathrm{E}+04$ & - & | /BS/ \\
\hline
\end{tabular}


Department of Energy

Pt. 835, App. A

\begin{tabular}{|c|c|c|c|c|c|c|c|}
\hline \multirow{3}{*}{ Radionuclide } & \multicolumn{3}{|c|}{ Absorption type $^{3}$} & \multicolumn{3}{|c|}{ Absorption type ${ }^{3}$} & \multirow{3}{*}{$\begin{array}{c}\begin{array}{c}\text { Stochastic or } \\
\text { organ or tis- } \\
\text { sue }^{1}\end{array} \\
(\mathrm{~F} / \mathrm{M} / \mathrm{S})\end{array}$} \\
\hline & \multicolumn{3}{|c|}{$\mu \mathrm{Ci} / \mathrm{mL}$} & \multicolumn{3}{|c|}{$\mathrm{Bq} / \mathrm{m}^{3}$} & \\
\hline & $\mathrm{F}$ & M & S & $\mathrm{F}$ & M & $S$ & \\
\hline $\begin{array}{l}\text { Np-236 (1 E+05 } \\
\text { yr). }\end{array}$ & - & $4 \mathrm{E}-11$ & - & - & $1 \mathrm{E}+00$ & - & /BS/ \\
\hline Np-236 (22 h) ..... & - & $5 E-08$ & - & - & $1 E+03$ & - & /BS/ \\
\hline Np-237 ..................... & - & $8 E-12$ & - & - & $3 E-01$ & - & /BS/ \\
\hline Np-238 …................ & - & $1 E-07$ & - & - & $4 \mathrm{E}+03$ & - & /BS/ \\
\hline Np-239 .................... & - & $5 E-07$ & - & - & $1 \mathrm{E}+04$ & - & $/ \mathrm{St} /$ \\
\hline Np-240 .................. & - & $2 E-06$ & - & - & $8 E+04$ & - & /ET/ \\
\hline Pu-234 .................... & - & $3 E-08$ & $3 E-08$ & - & $1 E+03$ & $1 \mathrm{E}+03$ & $/ \mathrm{St} / \mathrm{St}$ \\
\hline Pu-235 ……............. & - & $9 \mathrm{E}-05$ & $8 E-05$ & - & $3 E+06$ & $3 \mathrm{E}+06$ & $/ \mathrm{ET} / \mathrm{ET}$ \\
\hline Pu-236 ..................... & - & $1 \mathrm{E}-11$ & $7 E-11$ & - & $6 E-01$ & $2 \mathrm{E}+00$ & $/ \mathrm{BS} / \mathrm{St}$ \\
\hline Pu-237 .................... & - & $1 \mathrm{E}-06$ & $1 E-06$ & - & $7 E+04$ & $6 \mathrm{E}+04$ & $/ \mathrm{St} / \mathrm{St}$ \\
\hline Pu-238 ..................... & - & $6 E-12$ & $5 E-11$ & - & $2 E-01$ & $1 \mathrm{E}+00$ & /BS/St \\
\hline Pu-239 .................... & - & $5 E-12$ & $6 E-11$ & - & $2 E-01$ & $2 \mathrm{E}+00$ & /BS/BS \\
\hline Pu-240 .................... & - & $5 E-12$ & $6 \mathrm{E}-11$ & - & $2 E-01$ & $2 \mathrm{E}+00$ & /BS/BS \\
\hline Pu-241 ................... & - & $2 E-10$ & $2 E-09$ & - & $1 E+01$ & $1 \mathrm{E}+02$ & /BS/BS \\
\hline Pu-242 …................. & - & $5 E-12$ & $6 E-11$ & - & $2 E-01$ & $2 \mathrm{E}+00$ & /BS/BS \\
\hline Pu-243 ..................... & - & $5 E-06$ & $5 E-06$ & - & $1 E+05$ & $1 \mathrm{E}+05$ & /E/E \\
\hline Pu-244 …................ & - & $5 E-12$ & $6 \mathrm{E}-11$ & - & $2 E-01$ & $2 \mathrm{E}+00$ & /BS/BS \\
\hline Pu-245 .................... & - & $9 \mathrm{E}-07$ & $8 E-07$ & - & $3 E+04$ & $3 E+04$ & $/ \mathrm{St} / \mathrm{St}$ \\
\hline Pu-246 ................... & - & $8 E-08$ & $8 E-08$ & - & $3 E+03$ & $2 \mathrm{E}+03$ & $/ \mathrm{St} / \mathrm{St}$ \\
\hline Am-237 ................... & - & $8 \mathrm{E}-06$ & - & - & $3 E+05$ & - & /ET/ \\
\hline Am-238 …............... & - & $2 E-06$ & - & - & $9 \mathrm{E}+04$ & - & /BS/ \\
\hline Am-239 …............... & - & $1 \mathrm{E}-06$ & - & - & $6 \mathrm{E}+04$ & - & /ET/ \\
\hline Am-240 & - & $7 E-07$ & - & - & $2 E+04$ & - & /ET/ \\
\hline Am-241 ................. & - & $5 E-12$ & - & - & $1 E-01$ & - & /BS/ \\
\hline Am-242m $\ldots \ldots \ldots \ldots$ & - & $5 E-12$ & - & - & $1 \mathrm{E}-01$ & - & /BS/ \\
\hline Am-242 …................ & - & $4 E-08$ & - & - & $1 \mathrm{E}+03$ & - & $/ \mathrm{St} /$ \\
\hline Am-243 ................... & - & $5 E-12$ & - & - & $1 \mathrm{E}-01$ & - & /BS/ \\
\hline Am-244m & - & $3 E-06$ & - & - & $1 \mathrm{E}+05$ & - & /BS/ \\
\hline Am-244 .................. & - & $1 \mathrm{E}-07$ & - & - & $5 E+03$ & - & /BS/ \\
\hline Am-245 …............... & - & $5 E-06$ & - & - & $2 E+05$ & - & /ET/ \\
\hline Am-246m ................ & - & $6 \mathrm{E}-06$ & - & - & $2 E+05$ & - & /ET/ \\
\hline Am-246 ................... & - & $2 E-06$ & - & - & $9 E+04$ & - & /ET/ \\
\hline Cm-238 ................. & - & $1 E-07$ & - & - & $4 \mathrm{E}+03$ & - & $/ \mathrm{St} /$ \\
\hline $\mathrm{Cm}-240 \ldots \ldots \ldots \ldots$ & - & $2 E-10$ & - & - & $7 \mathrm{E}+00$ & - & /St/ \\
\hline $\mathrm{Cm}-241 \ldots \ldots \ldots \ldots \ldots$ & - & $2 E-08$ & - & - & $8 E+02$ & - & /St/ \\
\hline $\mathrm{Cm}-242 \ldots \ldots \ldots \ldots$ & - & $1 E-10$ & - & - & $5 \mathrm{E}+00$ & - & $/ \mathrm{St} /$ \\
\hline $\mathrm{Cm}-243 \ldots \ldots \ldots \ldots$ & - & $7 E-12$ & - & - & $2 E-01$ & - & /BS/ \\
\hline $\mathrm{Cm}-244 \ldots \ldots \ldots \ldots \ldots$ & - & $9 \mathrm{E}-12$ & - & - & $3 E-01$ & - & /BS/ \\
\hline Cm-245 ….............. & - & $5 E-12$ & - & - & $1 \mathrm{E}-01$ & - & /BS/ \\
\hline Cm-246 ................... & - & $5 E-12$ & - & - & $1 \mathrm{E}-01$ & - & /BS/ \\
\hline $\mathrm{Cm}-247 \ldots \ldots \ldots \ldots \ldots$ & - & $5 E-12$ & - & - & $2 E-01$ & - & /BS/ \\
\hline $\mathrm{Cm}-248 \ldots \ldots \ldots \ldots \ldots$ & - & $1 \mathrm{E}-12$ & - & - & $5 E-02$ & - & /BS/ \\
\hline Cm-249 …............... & - & $8 \mathrm{E}-06$ & - & - & $3 E+05$ & - & /ET/ \\
\hline $\mathrm{Cm}-250 \ldots \ldots \ldots \ldots$ & - & $2 E-13$ & - & - & $8 E-03$ & - & /BS/ \\
\hline Bk-245 …............... & - & $3 E-07$ & - & - & $1 \mathrm{E}+04$ & - & /St/ \\
\hline Bk-246 .................... & - & $8 \mathrm{E}-07$ & - & - & $3 E+04$ & - & /ET/ \\
\hline Bk-247 …................ & - & $3 E-12$ & - & - & $1 \mathrm{E}-01$ & - & /BS/ \\
\hline Bk-249 ..................... & - & $1 \mathrm{E}-09$ & - & - & $5 E+01$ & - & /BS/ \\
\hline Bk-250 ................... & - & $2 E-07$ & - & - & $9 E+03$ & - & /BS/ \\
\hline Cf-244 ……............ & - & $1 E-08$ & - & - & $5 E+02$ & - & /ET/ \\
\hline Cf-246 ……............ & - & $1 E-09$ & - & - & $5 E+01$ & - & $/ \mathrm{St} /$ \\
\hline Cf-248 …................ & - & $5 E-11$ & - & - & $2 E+00$ & - & /BS/ \\
\hline Cf-249 ……................ & - & $3 E-12$ & - & - & $1 \mathrm{E}-01$ & - & /BS/ \\
\hline Cf-250 ……............ & - & $7 E-12$ & - & - & $2 E-01$ & - & /BS/ \\
\hline Cf-251 ……............ & - & $3 E-12$ & - & - & $1 \mathrm{E}-01$ & - & /BS/ \\
\hline Cf-252 …................. & - & $1 E-11$ & - & - & $6 E-01$ & - & /BS/ \\
\hline Cf-253 ……............. & - & $5 E-10$ & - & - & $2 E+01$ & - & $/ \mathrm{St} /$ \\
\hline Cf-254 …............... & - & $2 E-11$ & - & - & $8 E-01$ & - & /BS/ \\
\hline Es-250 …................. & - & $4 \mathrm{E}-07$ & - & - & $1 \mathrm{E}+04$ & - & /BS/ \\
\hline Es-251 .................... & - & $3 E-07$ & - & - & $1 E+04$ & - & $/ \mathrm{St} /$ \\
\hline Es-253 …................ & - & $2 E-10$ & - & - & $9 \mathrm{E}+00$ & - & $/ \mathrm{St} /$ \\
\hline Es-254m …............. & - & $1 \mathrm{E}-09$ & - & - & $5 E+01$ & - & $/ \mathrm{St} /$ \\
\hline Es-254 .................... & - & $6 \mathrm{E}-11$ & - & - & $2 E+00$ & - & /BS/ \\
\hline Fm-252 …................ & - & $2 E-09$ & - & - & $8 \mathrm{E}+01$ & - & $/ \mathrm{St} /$ \\
\hline Fm-253 …................ & - & $1 \mathrm{E}-09$ & - & - & $6 \mathrm{E}+01$ & - & $/ \mathrm{St} /$ \\
\hline Fm-254 …............... & - & $6 \mathrm{E}-09$ & - & - & $2 E+02$ & - & /ET/ \\
\hline Fm-255 ................... & - & $2 E-09$ & - & - & $8 \mathrm{E}+01$ & - & $/ \mathrm{St} /$ \\
\hline Fm-257 ................... & - & $1 E-10$ & - & - & $4 \mathrm{E}+00$ & - & $/ \mathrm{St} /$ \\
\hline Md-257 .................... & - & $2 E-08$ & - & - & $1 \mathrm{E}+03$ & - & $/ \mathrm{St} /$ \\
\hline Md-258 .................... & - & $1 E-10$ & - & - & $4 \mathrm{E}+00$ & - & $/ \mathrm{St} /$ \\
\hline
\end{tabular}




\section{Pt. 835, App. C}

Footnotes For APPENDIX A

${ }^{1}$ A determination of whether the DACs are controlled by stochastic (St) or deterministic (organ or tissue) dose, or if they both give the same result (E), for each absorption type, is given in this column. The key to the organ notation for deterministic dose is: $\mathrm{BS}=$ Bone surface, $\mathrm{ET}=$ Extrathoracic, $\mathrm{K}=$ Kidney, $\mathrm{L}=$ Liver, and $\mathrm{T}$ $=$ Thyroid. A blank indicates that no calculations were performed for the absorption type shown.

2 The ICRP identifies these materials as soluble or reactive gases and vapors or highly soluble or reactive gases and vapors. For tritiated water, the inhalation DAC values allow for an additional $50 \%$ absorption through the skin, as described in ICRP Publication No. 68, Dose Coefficients for Intakes of Radionuclides by Workers. For elemental tritium, the DAC values include a factor that irradiation from gas within the lungs might increase the dose by $20 \%$.

${ }^{3} \mathrm{~A}$ dash indicates no values given for this data category.

${ }^{4}$ DAC values derived using hafnium tritide particle and are based on "observed activity" (i.e, only radiation emitted from the particle is considered). DAC values derived using methodology found in Radiological Control Programs for Special Tritium Compounds, DOE-HDBK-1184-2004

5 These values are appropriate for protection from radon combined with its shortlived decay products and are based on information given in ICRP Publication 65: Protection Against Radon-222 at Home and at Work and in DOE-STD-1121-98: Internal Dosimetry. The values given are for $100 \%$ equilibrium concentration conditions of the short-lived radon decay products with the parent. To allow for an actual measured equilibrium concentration or a demonstrated equilibrium concentration, the values given in this table should be multiplied by the ratio $(100 \%$ /actual $\%)$ or $(100 \%$ /demonstrated $\%$ ), respectively. Alternatively, the DAC values for Rn-220 and Rn-222 may be replaced by 2.5 working level (WL) and $0.83 \mathrm{WL}$, respectively, for appropriate limiting of decay

\section{CFR Ch. III (1-1-08 Edition)}

product concentrations. A WL is any combination of short-lived radon decay products, in one liter of air without regard to the degree of equilibrium, that will result in the ultimate emission of $1.3 \mathrm{E}+05 \mathrm{MeV}$ of alpha energy.

[72 FR 31927, June 8, 2007]

\section{APPENDIX B to PART 835 [RESERVED]}

APPENDIX C TO PART 835-DERIVED AIR CONCENTRATION (DAC) FOR WORKERS FROM EXTERNAL EXPOSURE DURING IMMERSION IN A CLOUD OF AIRBORNE RADIOACTIVE MATERIAL

a. The data presented in appendix $\mathbf{C}$ are to be used for controlling occupational exposures in accordance with $\S 835.209$, identifying the need for air monitoring in accordance with \$835.403 and identifying the need for posting of airborne radioactivity areas in accordance with $\S 835.603(d)$.

b. The air immersion DAC values shown in this appendix are based on a stochastic dose limit of 5 rems $(0.05 \mathrm{~Sv})$ per year. Four columns of information are presented: (1) Radionuclide; (2) half-life in units of seconds (s), minutes (min), hours (h), days (d), or years (yr); (3) air immersion DAC in units of $\mu \mathrm{Ci} / \mathrm{mL}$; and (4) air immersion $\mathrm{DAC}$ in units of $\mathrm{Bq} / \mathrm{m} 3$. The data are listed by radionuclide in order of increasing atomic mass. The air immersion DACs were calculated for a continuous, nonshielded exposure via immersion in a semi-infinite cloud of airborne radioactive material. The DACs listed in this appendix may be modified to allow for submersion in a cloud of finite dimensions.

c. The DAC values are given for individual radionuclides. For known mixtures of radionuclides, determine the sum of the ratio of the observed concentration of a particular radionuclide and its corresponding DAC for all radionuclides in the mixture. If this sum exceeds unity (1), then the DAC has been exceeded. For unknown radionuclides, the most restrictive DAC (lowest value) for those isotopes not known to be absent shall be used.

AIR IMMERSION DAC

\begin{tabular}{|c|c|c|c|}
\hline \multicolumn{4}{|c|}{ Air immersion DAC } \\
\hline Radionuclide & Half-Life & $(\mu \mathrm{Ci} / \mathrm{mL})$ & $\left(\mathrm{Bq} / \mathrm{m}^{3}\right)$ \\
\hline Ar-37 & $35.02 \mathrm{~d}$ & $1 \mathrm{E}+00$ & $4 \mathrm{E}+10$ \\
\hline Ar-39 ................. & $269 \mathrm{yr}$. & $4 \mathrm{E}-04$ & $1 \mathrm{E}+07$ \\
\hline Ar-41 & $1.827 \mathrm{~h}$ & $1 \mathrm{E}-06$ & $3 \mathrm{E}+04$ \\
\hline Kr-74 & $11.5 \min$ & $1 \mathrm{E}-06$ & $4 \mathrm{E}+04$ \\
\hline Kr-76 …… & $14.8 \mathrm{~h}$ & $3 \mathrm{E}-06$ & $1 \mathrm{E}+05$ \\
\hline Kr-77 & $74.7 \mathrm{~h}$ & $1 \mathrm{E}-06$ & $5 \mathrm{E}+04$ \\
\hline Kr-79 & $35.04 \mathrm{~h} \ldots \ldots \ldots \ldots \ldots . . . . .$. & $5 \mathrm{E}-06$ & $2 \mathrm{E}+05$ \\
\hline Kr-81 & $2.1 \mathrm{E}+05 \mathrm{yr}$ & $2 \mathrm{E}-04$ & $9 \mathrm{E}+06$ \\
\hline 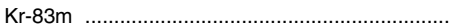 & $1.83 \mathrm{~h}$ & $2 \mathrm{E}-02$ & $9 \mathrm{E}+08$ \\
\hline 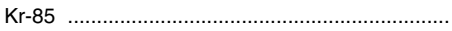 & 10.72 yr & $2 E-04$ & $9 \mathrm{E}+06$ \\
\hline Kr-85m & $4.48 \mathrm{~h}$ & $9 \mathrm{E}-06$ & $3 \mathrm{E}+05$ \\
\hline $\mathrm{Kr}-87$. & $76.3 \mathrm{~min}$. & $1 \mathrm{E}-06$ & $5 \mathrm{E}+04$ \\
\hline
\end{tabular}


AIR IMMERSION DAC-Continued

\begin{tabular}{|c|c|c|c|}
\hline \multicolumn{4}{|c|}{ Air immersion DAC } \\
\hline Radionuclide & Half-Life & $(\mu \mathrm{Ci} / \mathrm{mL})$ & $\left(\mathrm{Bq} / \mathrm{m}^{3}\right)$ \\
\hline $\mathrm{Kr}-88$ & $2.84 \mathrm{~h}$. & $6 \mathrm{E}-07$ & $2 \mathrm{E}+04$ \\
\hline $\mathrm{Xe}-120$ & $40.0 \mathrm{~min}$ & $3 \mathrm{E}-06$ & $1 \mathrm{E}+05$ \\
\hline 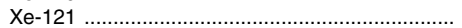 & $40.1 \mathrm{~min}$ & $7 \mathrm{E}-07$ & $2 \mathrm{E}+04$ \\
\hline 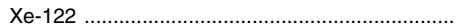 & $20.1 \mathrm{~h}$ & $2 \mathrm{E}-05$ & $1 \mathrm{E}+06$ \\
\hline${ }_{1}$ & $2.14 \mathrm{~h}$ & $2 \mathrm{E}-06$ & $8 \mathrm{E}+04$ \\
\hline Xe-125 & $16.8 \mathrm{~h}$ & $5 \mathrm{E}-06$ & $2 \mathrm{E}+05$ \\
\hline $\mathrm{Xe}-127 \quad \ldots \ldots \ldots \ldots \ldots \ldots \ldots \ldots \ldots \ldots \ldots \ldots \ldots \ldots \ldots$ & $36.406 \mathrm{~d}$................ & $5 \mathrm{E}-06$ & $2 \mathrm{E}+05$ \\
\hline 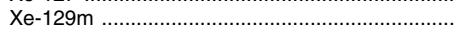 & $8.89 \mathrm{~d}$ & $6 \mathrm{E}-05$ & $2 \mathrm{E}+06$ \\
\hline Xe-131m (... & $11.84 \mathrm{~d}$ & $1 \mathrm{E}-04$ & $6 \mathrm{E}+06$ \\
\hline $\mathrm{Xe}-133$ & $5.245 \mathrm{~d}$ & $4 \mathrm{E}-05$ & $1 \mathrm{E}+06$ \\
\hline 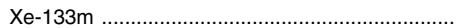 & $2.19 \mathrm{~d}$ & $4 \mathrm{E}-05$ & $1 \mathrm{E}+06$ \\
\hline 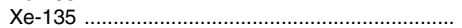 & 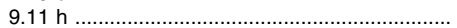 & $5 \mathrm{E}-06$ & $2 \mathrm{E}+05$ \\
\hline 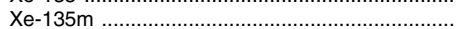 & $15.36 \mathrm{~min} \ldots \ldots \ldots$ & $3 \mathrm{E}-06$ & $1 \mathrm{E}+05$ \\
\hline $\mathrm{Xe}-138$ & $14.13 \mathrm{~min}$ & $1 \mathrm{E}-06$ & $4 \mathrm{E}+04$ \\
\hline
\end{tabular}

For any single radionuclide not listed above with decay mode other than alpha emission or spontaneous fission and with radioactive half-life less than two hours, the $\mathrm{DAC}$ value shall be $6 \mathrm{E}-06 \mu \mathrm{Ci} / \mathrm{mL}(2 \mathrm{E}+04 \mathrm{~Bq} /$ $\mathrm{m}^{3}$ ).

[72 FR 31940, June 8, 2007]

\section{APPENDIX D TO PART 835-SURFACE CONTAMINATION VALUES}

The data presented in appendix $\mathrm{D}$ are to be used in identifying the need for posting of contamination and high contamination areas in accordance with $\$ 835.603(\mathrm{e})$ and (f) and identifying the need for surface contamination monitoring and control in accordance with $\S \S 835.1101$ and 835.1102 .

SURFACE CONTAMINATION VALUES ${ }^{1}$ IN DPM/100 $\mathrm{CM}^{2}$

\begin{tabular}{|c|c|c|}
\hline Radionuclide & Removable 24 & $\begin{array}{c}\text { Total (Fixed + } \\
\text { Removable) }{ }^{2} \\
{ }_{3}\end{array}$ \\
\hline U-nat, U-235, U-238, and associated decay products & 71,000 & 75,000 \\
\hline 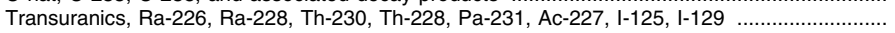 & 20 & 500 \\
\hline 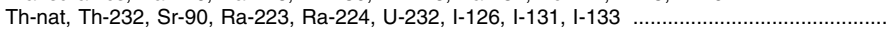 & 200 & 1,000 \\
\hline Beta-gamma emitters (nuclides with decay modes other than alpha emission or spontaneous & & 5000 \\
\hline $\begin{array}{l}\text { fission) except Sr-90 and others noted above }{ }^{5} \\
\text { Tritium and STCs } 6.1\end{array}$ & $\begin{array}{r}1,000 \\
10,000\end{array}$ & $\begin{array}{r}5,000 \\
\text { See Footnote }\end{array}$ \\
\hline
\end{tabular}

${ }^{1}$ The values in this appendix, with the exception noted in footnote 5 , apply to radioactive contamination deposited on, but not incorporated into the interior or matrix of the contaminated item. Where surface contamination by both alpha-and beta-gammaemitting nuclides exists, the limits established for alpha-and beta-gamma-emitting nuclides apply independently.

${ }_{2}$ As used in this table, dpm (disintegrations per minute) means the rate of emission by radioactive material as determined by correcting the counts per minute observed by an appropriate detector for background, efficiency, and geometric factors associated with the instrumentation.

${ }_{3}^{3}$ The levels may be averaged over one square meter provided the maximum surface activity in any area of $100 \mathrm{~cm}^{2}$ is less than three times the value specified. For purposes of averaging, any square meter of surface shall be considered to be above the surface contamination value if: (1) From measurements of a representative number of sections it is determined that the average contamination level exceeds the applicable value; or (2) it is determined that the sum of the activity of all isolated spots or particles in any $100 \mathrm{~cm}^{2}$ area exceeds three times the applicable value.

${ }^{4}$ The amount of removable radioactive material per $100 \mathrm{~cm}^{2}$ of surface area should be determined by swiping the area with dry filter or soft absorbent paper, applying moderate pressure, and then assessing the amount of radioactive material on the swipe with an appropriate instrument of known efficiency. (Note- The use of dry material may not be appropriate for tritium.) When removable contamination on objects of surface area less than $100 \mathrm{~cm}^{2}$ is determined, the activity per unit area shall be able contamination levels if direct scan surveys indicate that the total residual surface contamination levels are within the limits for removable contamination.

5 This category of radionuclides includes mixed fission products, including the Sr-90 which is present in them. It does not apply to Sr-90 which has been separated from the other fission products or mixtures where the Sr-90 has been enriched.

to Sr-90 which has been separated from the other fission products or mixtures where the Sr-90 has been enriched. the extent to which such contamination may migrate to the surface in order to ensure the surface contamination value provided in this appendix is not exceeded. Once this contamination migrates to the surface, it may be removable, not fixed; therefore a "This appendix is not exceeded. Once this contamination migrates to the surface, it may be removable, not fixed; therefore, a "Total" value does not apply. In certain cases, a "Total" value of $10,000 \mathrm{dpm} / 100 \mathrm{~cm}^{2}$ may be applicable either to metals, of the
types which form insoluble special tritium compounds that have been exposed to tritium; or to bulk materials to which particles of insoluble special tritium compound are fixed to a surface.

7 These limits only apply to the alpha emitters within the respective decay series.

[58 FR 65485, Dec. 14, 1993, as amended at 63 FR 59688, Nov. 4, 1998; 72 FR 31940, June 8, 2007] 


\section{Pt. 835, App. E}

APPENDIX E TO PART 835-VALUES FOR Establishing SEALED RADIOACTIVE SOURCE ACCOUNTABILITY AND RADIOACTIVE MATERIal Posting AND LABELING REQUIREMENTS

The data presented in appendix $\mathrm{E}$ are to be used for identifying accountable sealed radioactive sources and radioactive material areas as those terms are defined at $\S 835.2$ (a), establishing the need for radioactive material area posting in accordance with $\$ 835.603(\mathrm{~g})$, and establishing the need for radioactive material labeling in accordance with $\S 835.605$.

\begin{tabular}{|c|c|}
\hline Nuclide & Activity $(\mu \mathrm{Ci})$ \\
\hline $\mathrm{H}-3$ & $1.5 \mathrm{E}+08$ \\
\hline $\mathrm{Be}-7$ & $3.1 \mathrm{E}+03$ \\
\hline $\mathrm{Be}-10 \ldots \ldots \ldots \ldots \ldots \ldots$ & $1.4 \mathrm{E}+05$ \\
\hline C-14 $\ldots \ldots \ldots$ & $4.6 \mathrm{E}+06$ \\
\hline 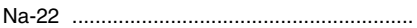 & $1.9 \mathrm{E}+01$ \\
\hline 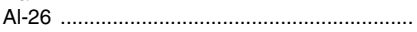 & $1.5 \mathrm{E}+01$ \\
\hline Si-32 .............. & $4.9 \mathrm{E}+04$ \\
\hline 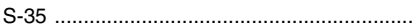 & $2.4 \mathrm{E}+06$ \\
\hline 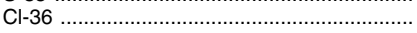 & $5.2 \mathrm{E}+05$ \\
\hline $\mathrm{K}-40 \ldots \ldots \ldots$ & $2.7 \mathrm{E}+02$ \\
\hline Сa-41 …….............. & $9.3 \mathrm{E}+06$ \\
\hline 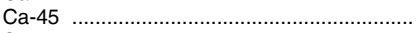 & $1.1 \mathrm{E}+06$ \\
\hline Sc-46 & $6.2 \mathrm{E}+01$ \\
\hline Ti-44 & $1.5 \mathrm{E}+02$ \\
\hline 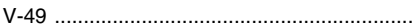 & $1.0 \mathrm{E}+08$ \\
\hline Mn-53 & $7.5 \mathrm{E}+07$ \\
\hline $\mathrm{Mn}-54 \ldots \ldots \ldots \ldots \ldots$ & $6.5 \mathrm{E}+01$ \\
\hline $\mathrm{Fe}-55 \ldots \ldots \ldots \ldots \ldots \ldots \ldots$ & $2.9 \mathrm{E}+06$ \\
\hline Fe-59 ……… & $1.9 \mathrm{E}+02$ \\
\hline $\mathrm{Fe}-60 \ldots \ldots \ldots$ & $8.1 \mathrm{E}+03$ \\
\hline Co-56 ........ & $3.9 \mathrm{E}+01$ \\
\hline 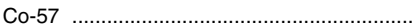 & $2.3 \mathrm{E}+02$ \\
\hline Co-58 & $1.3 \mathrm{E}+02$ \\
\hline Co-60 & $1.7 \mathrm{E}+01$ \\
\hline 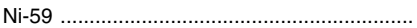 & $3.2 \mathrm{E}+06$ \\
\hline 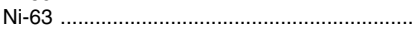 & $1.3 \mathrm{E}+06$ \\
\hline Zn-65 ................. & $1.1 \mathrm{E}+02$ \\
\hline 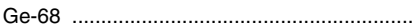 & $5.6 \mathrm{E}+02$ \\
\hline As-73 & $5.3 \mathrm{E}+02$ \\
\hline Se-75 ……............. & $6.3 \mathrm{E}+01$ \\
\hline Se-79 & 8.7E+05 \\
\hline 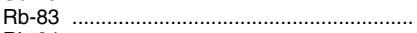 & $9.1 \mathrm{E}+01$ \\
\hline Rb-84 & $2.0 \mathrm{E}+02$ \\
\hline Sr-85 & $1.2 \mathrm{E}+02$ \\
\hline 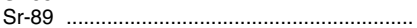 & $4.8 \mathrm{E}+05$ \\
\hline Sr-90 & $3.5 \mathrm{E}+04$ \\
\hline Y-88 …………...... & 3.3E+01 \\
\hline 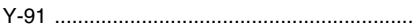 & $5.0 \mathrm{E}+04$ \\
\hline Zr-88 & $1.1 \mathrm{E}+02$ \\
\hline Zr-93 & $9.3 \mathrm{E}+04$ \\
\hline 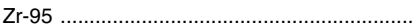 & $1.9 \mathrm{E}+02$ \\
\hline Nb-91 & $6.9 \mathrm{E}+01$ \\
\hline $\mathrm{Nb}-91 \mathrm{~m}$ & $3.6 \mathrm{E}+02$ \\
\hline Nb-92 …................ & $1.8 \mathrm{E}+01$ \\
\hline Nb-93m & $4.4 \mathrm{E}+02$ \\
\hline Nb-94 & $2.3 \mathrm{E}+01$ \\
\hline 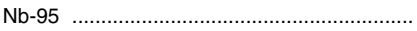 & $3.4 \mathrm{E}+02$ \\
\hline Mo-93 & 7.7E+01 \\
\hline 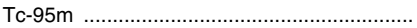 & $1.3 \mathrm{E}+02$ \\
\hline 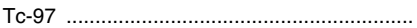 & $8.1 \mathrm{E}+01$ \\
\hline Tc-97m & $3.5 \mathrm{E}+02$ \\
\hline 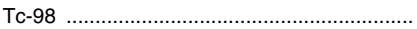 & $2.5 \mathrm{E}+01$ \\
\hline 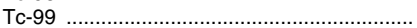 & $8.4 \mathrm{E}+05$ \\
\hline Ru-103 & $4.4 \mathrm{E}+02$ \\
\hline Ru-106 & $2.5 \mathrm{E}+02$ \\
\hline Rh-101 ................... & $8.7 \mathrm{E}+05$ \\
\hline
\end{tabular}

10 CFR Ch. III (1-1-08 Edition)

\begin{tabular}{|c|c|}
\hline Nuclide & Activity $(\mu \mathrm{Ci})$ \\
\hline Rh-102 & $3.0 \mathrm{E}+05$ \\
\hline 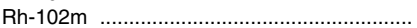 & $6.4 \mathrm{E}+05$ \\
\hline 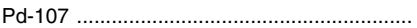 & $9.3 \mathrm{E}+06$ \\
\hline Ag-105 & $3.3 \mathrm{E}+06$ \\
\hline $\mathrm{Ag}-108 \mathrm{~m}$ & $1.8 \mathrm{E}+01$ \\
\hline 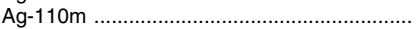 & $2.2 \mathrm{E}+01$ \\
\hline Cd-109 & $1.6 \mathrm{E}+02$ \\
\hline Cd-113m ... & $2.0 \mathrm{E}+04$ \\
\hline Cd-115m & $1.0 \mathrm{E}+04$ \\
\hline In-114m …….......... & $7.7 \mathrm{E}+02$ \\
\hline $\mathrm{Sn}-113$ & $3.1 \mathrm{E}+02$ \\
\hline 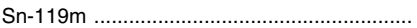 & 3.3E+02 \\
\hline 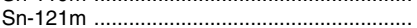 & $8.1 \mathrm{E}+05$ \\
\hline Sn-123 & $1.3 \mathrm{E}+04$ \\
\hline 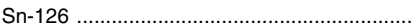 & $1.8 \mathrm{E}+02$ \\
\hline 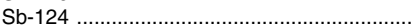 & $9.1 \mathrm{E}+01$ \\
\hline Sb-125 & $6.7 \mathrm{E}+01$ \\
\hline Te-121m . & $1.8 \mathrm{E}+02$ \\
\hline 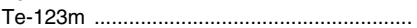 & $2.8 \mathrm{E}+02$ \\
\hline 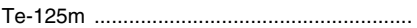 & 4.4E+02 \\
\hline Te-127m . & $8.0 \mathrm{E}+02$ \\
\hline 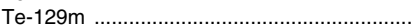 & $2.3 \mathrm{E}+03$ \\
\hline 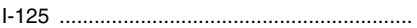 & $3.5 \mathrm{E}+02$ \\
\hline $\mathrm{I}-129$ & $1.8 \mathrm{E}+02$ \\
\hline Cs-134 ......... & $2.6 \mathrm{E}+01$ \\
\hline 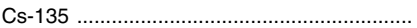 & $1.3 \mathrm{E}+06$ \\
\hline Cs-137. & $6.0 \mathrm{E}+01$ \\
\hline Ba-133 .............. & $5.1 \mathrm{E}+01$ \\
\hline La-137 & 2.7E+05 \\
\hline Ce-139 .............. & 2.4E+02 \\
\hline Ce-141 & $2.4 \mathrm{E}+03$ \\
\hline Ce-144 & $1.4 \mathrm{E}+03$ \\
\hline $\mathrm{Pm}-143 \ldots . .$. & $1.3 \mathrm{E}+02$ \\
\hline - & $2.9 \mathrm{E}+01$ \\
\hline $\mathrm{Pm}-145$................. & $2.6 \mathrm{E}+02$ \\
\hline 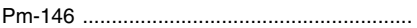 & 4.4E+01 \\
\hline 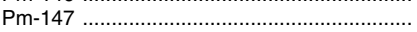 & 7.7E+05 \\
\hline $\mathrm{Pm}-148 \mathrm{~m} \ldots \ldots \ldots .$. & $1.0 \mathrm{E}+02$ \\
\hline 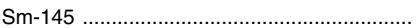 & $2.4 \mathrm{E}+06$ \\
\hline Sm-146 & $4.0 \mathrm{E}+02$ \\
\hline Sm-151 ....... & $2.5 \mathrm{E}+05$ \\
\hline 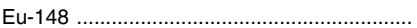 & $1.1 \mathrm{E}+06$ \\
\hline Eu-149 & $1.1 \mathrm{E}+07$ \\
\hline 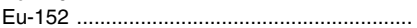 & $3.1 \mathrm{E}+01$ \\
\hline 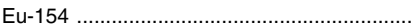 & $3.1 \mathrm{E}+01$ \\
\hline Eu-155 …........... & $3.6 \mathrm{E}+02$ \\
\hline 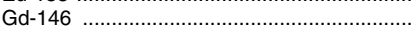 & $5.1 \mathrm{E}+05$ \\
\hline Gd-148 & $9.0 \mathrm{E}+01$ \\
\hline 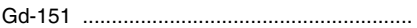 & $2.9 \mathrm{E}+06$ \\
\hline Gd-153 & $2.1 \mathrm{E}+02$ \\
\hline Tb-157 & $2.5 \mathrm{E}+03$ \\
\hline 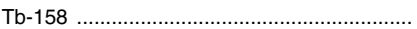 & $9.0 \mathrm{E}+04$ \\
\hline Tb-160 & $1.2 \mathrm{E}+02$ \\
\hline Dy-159 & $1.0 \mathrm{E}+07$ \\
\hline Ho-166m ... & $2.1 \mathrm{E}+01$ \\
\hline Tm-170 & $8.4 \mathrm{E}+03$ \\
\hline $\mathrm{Tm}-171 \ldots \ldots \ldots \ldots \ldots \ldots \ldots$ & $2.8 \mathrm{E}+04$ \\
\hline 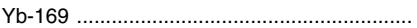 & $5.5 \mathrm{E}+02$ \\
\hline 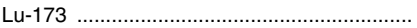 & $1.8 \mathrm{E}+06$ \\
\hline 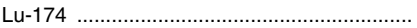 & $9.3 \mathrm{E}+05$ \\
\hline 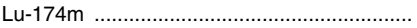 & $1.0 \mathrm{E}+06$ \\
\hline Lu-177m & $5.8 \mathrm{E}+01$ \\
\hline 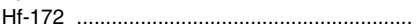 & $7.3 \mathrm{E}+04$ \\
\hline 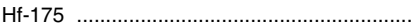 & $3.0 \mathrm{E}+06$ \\
\hline 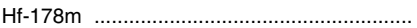 & 8.7E+03 \\
\hline Hf-181 & $3.4 \mathrm{E}+02$ \\
\hline $\mathrm{Hf}-182$ & $7.5 \mathrm{E}+03$ \\
\hline Та-179 & $9.3 \mathrm{E}+06$ \\
\hline Ta-182 & $7.3 \mathrm{E}+01$ \\
\hline W-181 & $1.0 \mathrm{E}+03$ \\
\hline W-185 & $3.9 \mathrm{E}+06$ \\
\hline W-188 & $6.3 \mathrm{E}+04$ \\
\hline Re-183 & $5.3 \mathrm{E}+02$ \\
\hline Re-184 & $2.6 \mathrm{E}+02$ \\
\hline
\end{tabular}


Department of Energy

\begin{tabular}{|c|c|}
\hline Nuclide & Activity $(\mu \mathrm{Ci})$ \\
\hline $\operatorname{Re}-184 m$ & $1.5 \mathrm{E}+02$ \\
\hline 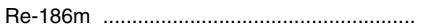 & $3.4 \mathrm{E}+05$ \\
\hline Os-185 ……..... & $1.3 \mathrm{E}+02$ \\
\hline Os-194 ….............. & $6.4 \mathrm{E}+04$ \\
\hline Ir-192 & $1.3 \mathrm{E}+02$ \\
\hline 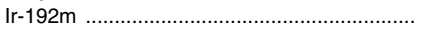 & $1.4 \mathrm{E}+05$ \\
\hline Ir-194m (. & $2.7 \mathrm{E}+01$ \\
\hline 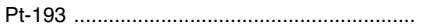 & $8.7 \mathrm{E}+07$ \\
\hline $\mathrm{Au}-195 \ldots \ldots \ldots \ldots \ldots$ & $4.8 \mathrm{E}+02$ \\
\hline $\mathrm{Hg}-194 \ldots$ & $5.2 \mathrm{E}+04$ \\
\hline 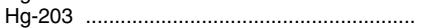 & $4.9 \mathrm{E}+02$ \\
\hline TI-204 ................ & $2.2 \mathrm{E}+04$ \\
\hline 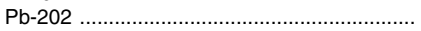 & $1.9 \mathrm{E}+05$ \\
\hline 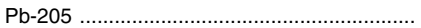 & $9.0 \mathrm{E}+01$ \\
\hline Pb-210 & $9.2 \mathrm{E}+01$ \\
\hline 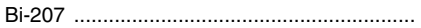 & $1.7 \mathrm{E}+01$ \\
\hline 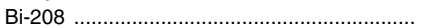 & $1.5 \mathrm{E}+01$ \\
\hline Bi-210m & $1.2 \mathrm{E}+03$ \\
\hline Po-209 (.). & $6.3 \mathrm{E}+03$ \\
\hline Po-210 ........ & $1.2 \mathrm{E}+03$ \\
\hline Ra-226 & $2.2 \mathrm{E}+02$ \\
\hline Ra-228 & $1.5 \mathrm{E}+03$ \\
\hline Ac-227 ................ & $4.2 \mathrm{E}+00$ \\
\hline Th-228 .... & $8.4 \mathrm{E}+01$ \\
\hline Th-229 & $3.1 \mathrm{E}+01$ \\
\hline Th-230 & $5.4 \mathrm{E}+00$ \\
\hline Th-232 ............... & $9.3 \mathrm{E}+01$ \\
\hline 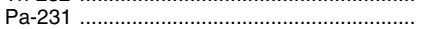 & 3.0E+01 \\
\hline $\mathrm{U}-232 \ldots \ldots \ldots \ldots \ldots$ & $1.0 \mathrm{E}+02$ \\
\hline 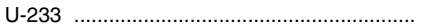 & $3.9 \mathrm{E}+02$ \\
\hline 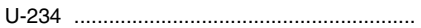 & $2.9 \mathrm{E}+02$ \\
\hline U-235 & $6.7 \mathrm{E}+01$ \\
\hline 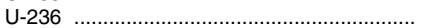 & 3.1E+02 \\
\hline U-238 & $3.5 \mathrm{E}+02$ \\
\hline Np-235 & $1.1 \mathrm{E}+02$ \\
\hline $\mathrm{Np}-236 \ldots \ldots \ldots \ldots$ & $2.1 \mathrm{E}+01$ \\
\hline 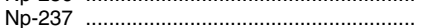 & $4.9 \mathrm{E}+01$ \\
\hline Pu-236 & $2.0 \mathrm{E}+02$ \\
\hline $\mathrm{Pu}-237$.................... & $3.3 \mathrm{E}+02$ \\
\hline Pu-238 & $9.0 \mathrm{E}+01$ \\
\hline 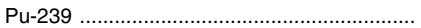 & $8.4 \mathrm{E}+01$ \\
\hline Pu-240 & $8.4 \mathrm{E}+01$ \\
\hline 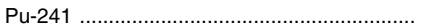 & $4.6 \mathrm{E}+03$ \\
\hline Pu-242 ............. & $8.7 \mathrm{E}+01$ \\
\hline 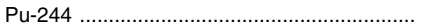 & $9.0 \mathrm{E}+01$ \\
\hline Am-241. & $7.2 \mathrm{E}+01$ \\
\hline 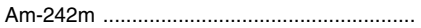 & $1.1 \mathrm{E}+02$ \\
\hline 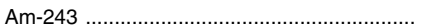 & 7.3E+01 \\
\hline 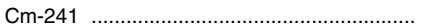 & $1.0 \mathrm{E}+05$ \\
\hline …… & $6.2 \mathrm{E}+02$ \\
\hline 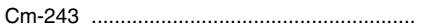 & $4.8 \mathrm{E}+01$ \\
\hline 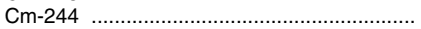 & $1.5 \mathrm{E}+02$ \\
\hline $\mathrm{Cm}-245$ & $5.0 \mathrm{E}+01$ \\
\hline $\mathrm{Cm}-246$ & $1.0 \mathrm{E}+02$ \\
\hline Cm-247 & $8.5 \mathrm{E}+01$ \\
\hline $\mathrm{Cm}-248$ & $2.8 \mathrm{E}+01$ \\
\hline 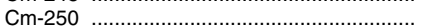 & $5.4 \mathrm{E}+00$ \\
\hline Bk-247 & $6.0 \mathrm{E}+01$ \\
\hline 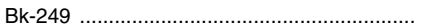 & $2.7 \mathrm{E}+04$ \\
\hline (1) & $4.4 \mathrm{E}+02$ \\
\hline Cf-249 & $5.5 \mathrm{E}+01$ \\
\hline Cf-250 & $1.2 \mathrm{E}+02$ \\
\hline Cf-251 & $5.3 \mathrm{E}+01$ \\
\hline 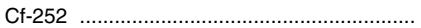 & $5.2 \mathrm{E}+00$ \\
\hline 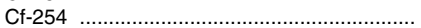 & $1.2 \mathrm{E}+02$ \\
\hline Es-254 . & $6.3 \mathrm{E}+01$ \\
\hline Es-255 & $8.8 \mathrm{E}+03$ \\
\hline 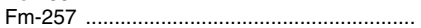 & $5.1 \mathrm{E}+02$ \\
\hline 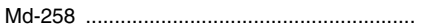 & $6.1 \mathrm{E}+02$ \\
\hline
\end{tabular}

Any alpha emitting radionuclide not listed in appendix $\mathrm{E}$ and mixtures of alpha emitters of unknown composition have a value of 10 $\mu \mathrm{Ci}$.
$\S 840.1$

With the exception that any type of STC has a value of $10 \mathrm{Ci}$, any radionuclide other than alpha emitting radionuclides not listed in appendix $\mathrm{E}$ and mixtures of beta emitters of unknown composition have a value of 100 $\mu \mathrm{Ci}$.

NoTE: Where there is involved a mixture of radionuclides in known amounts, derive the value for the mixture as follows: determine, for each radionuclide in the mixture, the ratio between the quantity present in the mixture and the value otherwise established for the specific radionuclide when not in the mixture. If the sum of such ratios for all radionuclides in the mixture exceeds unity (1), then the accountability criterion has been exceeded.

[72 FR 31940, June 8, 2007]

\section{PART 840-EXTRAORDINARY NUCLEAR OCCURRENCES}

Sec.

840.1 Scope and purpose.

840.2 Procedures.

840.3 Determination of extraordinary nuclear occurrence.

840.4 Criterion I-Substantial discharge of radioactive material or substantial radiation levels offsite.

840.5 Criterion II-Substantial damages to persons offsite or property offsite.

AUTHORITY: Sec. 161 of the Atomic Energy Act of 1954, Pub. L. 83-703, 68 Stat. 919 (42 U.S.C. 2201); sec. 170 of the Atomic Energy Act of 1954, Pub. L. 85-256, 71 Stat. 576, as amended by Pub. L. 89-645, 80 Stat. 891 (42 U.S.C. 2210); Department of Energy Organization Act, Pub. L. 95-91, 91 Stat. 565-613 (42 U.S.C. 7101-7352).

SouRCE: 49 FR 21473, May 21, 1984, unless otherwise noted.

\section{$\$ 840.1$ Scope and purpose.}

(a) Scope. This subpart applies to those DOE contractor activities to which the nuclear hazards indemnity provisions in 41 CFR 9-50.704-6 apply, and to other persons indemnified with respect to such activities.

(b) Purpose. One purpose of this subpart is to set forth the criteria which the DOE proposes to follow in order to determine whether there has been an "extraordinary nuclear occurrence." The other purpose is to establish the conditions of the waivers of defenses proposed for incorporation in indemnity agreements.

(1) The system is to come into effect only where the discharge or dispersal constitutes a substantial amount of 